\title{
Série Educar
}

\section{Matemática}

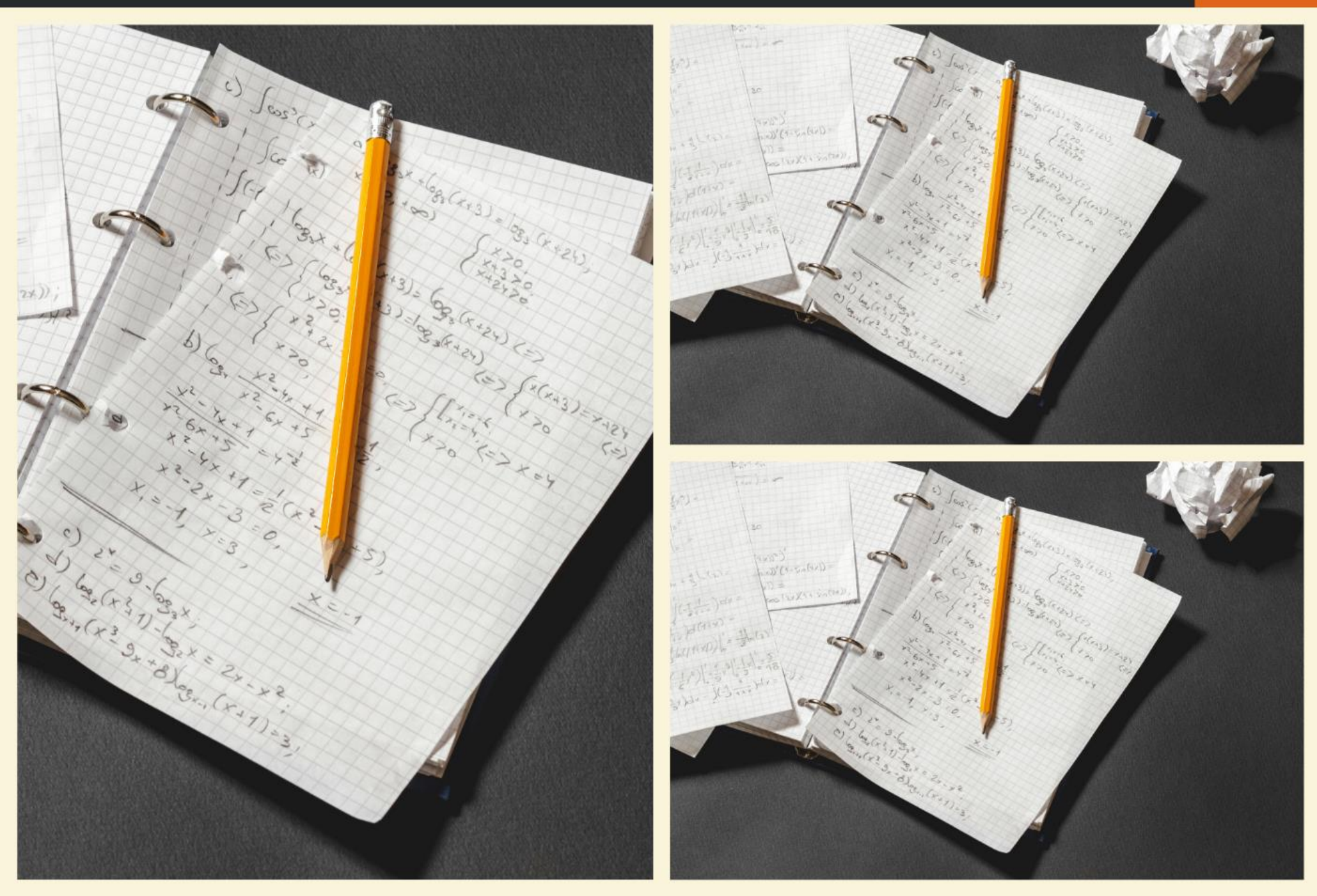

< Editora Poisson

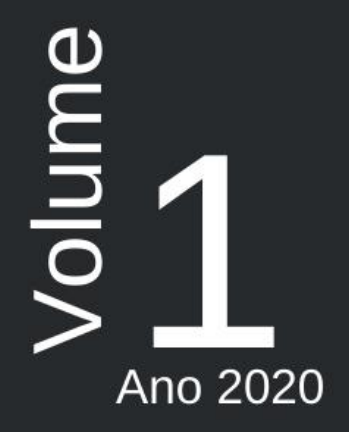


Editora Poisson

(organizadora)

\section{Série Educar - Volume 1 \\ Matemática}

1a Edição

Belo Horizonte

Poisson

2020 
Editor Chefe: Dr. Darly Fernando Andrade

\section{Conselho Editorial}

Dr. Antônio Artur de Souza - Universidade Federal de Minas Gerais

Ms. Davilson Eduardo Andrade

Dra. Elizângela de Jesus Oliveira - Universidade Federal do Amazonas

Msc. Fabiane dos Santos

Dr. José Eduardo Ferreira Lopes - Universidade Federal de Uberlândia

Dr. Otaviano Francisco Neves - Pontifícia Universidade Católica de Minas Gerais

Dr. Luiz Cláudio de Lima - Universidade FUMEC

Dr. Nelson Ferreira Filho - Faculdades Kennedy

Ms. Valdiney Alves de Oliveira - Universidade Federal de Uberlândia

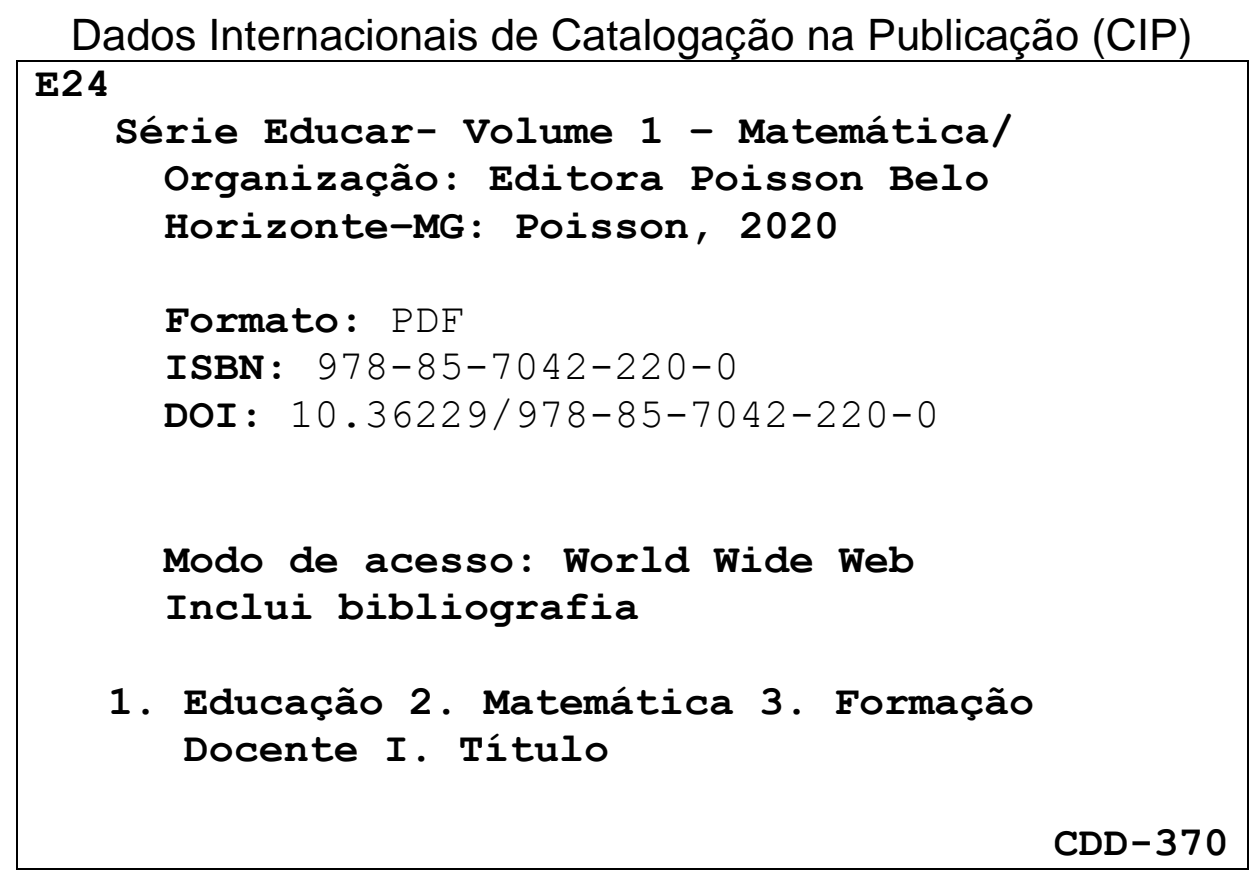

O conteúdo dos artigos e seus dados em sua forma, correção e confiabilidade são de responsabilidade exclusiva dos seus respectivos autores

www.poisson.com.br

contato@poisson.com.br 


\section{SUMÁRIO}

Capítulo 1: Etnomatemática uma prática pedagógica realizada com alunos da $2^{\underline{a}}$ série do ensino médio um relato de experiência. 08

Leonardo Cinésio Gomes, Clebson Santos da Silva, Egracieli dos Santos Ananias, Jessica Claudia de Lima dos Santos, Eduardo da Silva Andrade, Vagner Santos da Silva

DOI: 10.36229/978-85-7042-220-0.CAP.01

Capítulo 2: Equidade avaliativa servida à mesa: A "Gastromática" como uma proposta metodológica ativa para o ensino e avaliação da Etnomatemática 14

Edivan Vieira Lima, Sheila Pires dos Santos, Solimar Barros Ramires DOI: 10.36229/978-85-7042-220-0.CAP.02

Capítulo 3: Ensino de Geometria da Teoria a Práxis: Contribuições para a prática pedagógica do professor de Matemática

Vania de Moura Barbosa Duarte, Marcos Antônio Heleno Duarte

DOI: $10.36229 / 978-85-7042-220-0 . C A P .03$

Capítulo 4: Processo de ensino e aprendizagem em disciplina de Geometria Espacial: Uma experiência com produção de texto e material concreto. 28

Valter Locci, Emília de Mendonça Rosa Marques

DOI: $10.36229 / 978-85-7042-220-0 . C A P .04$

Capítulo 5: Matemática e jujubas: Uma proposta lúdica do ensino de figuras e sólidos geométricos nos anos iniciais. 35

Hellen Cris de Almeida Rodrigues, Emanuella Silveira Vasconcelos, Marnilde Silva de Farias, João Luiz da Costa Barros

DOI: 10.36229/978-85-7042-220-0.CAP.05

Capítulo 6: Abordagem intuitiva do conceito de área e perímetro de figuras planas através do Simulador PHET 40

Gisele Scremin, Maria Madalena Dullius, Italo Gabriel Neide DOI: $10.36229 / 978-85-7042-220-0 . C A P .06$

Capítulo 7: Ensino de vetores: Sequência didática fundamentada na engenharia didática 49

César Marcos do Nascimento Lucas, Raimundo Nonato Barbosa Cavalcante

DOI: $10.36229 / 978-85-7042-220-0 . C A P .07$ 


\section{SUMÁRIO}

Capítulo 8: As práticas metodológicas inovadoras no ensino da Matemática das Escolas Municipais da Cidade de Água Branca-PI 55

Azenate Pereira de Sousa, Edimar Campelo Araujo, Osiel Cesar da Trindade Júnior

DOI: $10.36229 / 978-85-7042-220-0 . C A P .08$

Capítulo 9: Ensino da matemática e prática docente: Memórias escolares da tabuada em narrativas de idosos(as) 65

José Jorge Casimiro dos Santos, Zélia Maria de Arruda Santiago

DOI: $10.36229 / 978-85-7042-220-0 . C A P .09$

Capítulo 10: Uma reflexão sobre a educação matemática no ensino de jovens e adultos 70

Bruno Thayguara de Oliveira Ribeiro, Eloy da Silva Rocha

DOI: $10.36229 / 978-85-7042-220-0 . C A P .10$

Capítulo 11: 0 uso de vídeo-aulas como recurso didático no ensino e aprendizagem de Cálculo Diferencial e Integral 78

Paulo Malicka Musiau

DOI: $10.36229 / 978-85-7042-220-0 . C A P .11$

Capítulo 12: Aprendizagem Matemática: Relato de experiência com utilização de resíduo do óleo de dendê.

Luciano Santana de Cerqueira, Bianca Daéb's Seixas Almeida, Maise Silva

DOI: $10.36229 / 978-85-7042-220-0 . C A P .12$

Capítulo 13: História da Matemática auxiliando na construção de conceitos: 0 caso dos números irracionais. 90

Vania de Moura Barbosa Duarte, Marcos Antonio Heleno Duarte

DOI: $10.36229 / 978-85-7042-220-0 . C A P .13$

Capítulo 14: Dominó de Frações: Uma ferramenta para o ensino de frações. 97

Jean Oliveira da Silva, Hailson da Costa Trindade, Francklim Sideney Vidal de Santana, Thamy Saraiva Alves

DOI: $10.36229 / 978-85-7042-220-0 . C A P .14$ 


\section{SUMÁRIO}

Capítulo 15: A Teoria dos Campos Conceituais e suas implicações sobre o Campo Aditivo para o ensino de Matemática no $6^{\circ}$ ano do Ensino Fundamental 105

Walisson da Silva Araújo, Rosimeyre Vieira da Silva

DOI: $10.36229 / 978-85-7042-220-0 . C A P .15$

Capítulo 16: Avaliação da aprendizagem na proposta de investigação matemática com o geogebra. 118

Maxwell Gonçalves Araújo, Duelci Aparecido de Freitas Vaz, Elivanete Alves de Jesus, Paulo César de Jesus Cruvinel DOI: 10.36229/978-85-7042-220-0.CAP.16

Capítulo 17: 0 pensamento relacional na Álgebra: 0 que sabem os estudantes?... 125

Sheila Marques Moreira Medeiros, Mayara Dias de Araújo, Severina Andréa Dantas de Farias DOI: $10.36229 / 978-85-7042-220-0 . C A P .17$

Capítulo 18: Fatores que interferem na motivação para o aprendizado da Matemática.

Ivan Rodrigues de Moura, Vilani Ferreira Feitosa Amaral

DOI: $10.36229 / 978-85-7042-220-0 . C A P .18$

Capítulo 19: Interdisciplinaridade entre Educação Física e Matemática: Construindo conceitos matemáticos através de uma aplicação no Campeonato Francês de Vôlei.. 141

Nicéias Silva Vilela, Dâmocles Aurélio Nascimento da Silva Alves

DOI: 10.36229/978-85-7042-220-0.CAP.19

Capítulo 20: Reflexões sobre a formação matemática do Pedagogo 153

Nayara do Nascimento Pereira, Nayara Lima Dutra Cavalcante, Milene de Fátima Soares DOI: $10.36229 / 978-85-7042-220-0 . C A P .20$

Capítulo 21: Perfil do Professor de Matemática: Uma análise sob a percepção dos docentes da Educação Básica

Armando da Silva Pereira Neto, Erivelton da Silva Paz, Marilene Rosa dos Santos

DOI: $10.36229 / 978-85-7042-220-0 . C A P .21$ 


\section{SUMÁRIO}

Capítulo 22: Formação docente nas aprendizagens matemáticas dos Discentes no 9o ano do Ensino Básico 169

Valmiro de Santiago Lima, Sheyla Silva Thé Freitas, Maria dos Milagres Fernandes Diniz Chaves DOI: $10.36229 / 978-85-7042-220-0 . C A P .22$

Capítulo 23: A Importância do PIBID na formação-docente no ensino da Matemática: Um relato de experiência em uma Escola Pública no Estado do Pará.

Darlan Douglas Barros Pereira, Ismael Smylle da Silva Quirino

DOI: $10.36229 / 978-85-7042-220-0 . C A P .23$

Capítulo 24: A importância de atividades lúdicas para a aprendizagem da matemática por crianças do Ensino Fundamental: Uma experiência a partir do PIBID 179

Graziela Aquino do Nascimento, Lindiane Duarte da Silva, Pascoal Eron Santos de Souza DOI: $10.36229 / 978-85-7042-220-0 . C A P .24$

Capítulo 25: As mulheres na matemática e suas principais contribuições. 179

Alane Élen Silva de Medeiros, Gisele Regina Santos Oliveira DOI: 10.36229/978-85-7042-220-0.CAP.25

Autores: 188 


\section{Capítulo 1}

Etnomatemática uma prática pedagógica realizada com alunos da 2 a série do ensino médio um relato de experiência

\section{Leonardo Cinésio Gomes}

Clebson Santos da Silva

Egracieli dos Santos Ananias

Jessica Claudia de Lima dos Santos

Eduardo da Silva Andrade

Vagner Santos da Silva

Resumo: 0 presente trabalho trata-se de um relato de experiência, uma pratica pedagógica exitosa que aconteceu no ano de 2018. Um dos autores deste trabalho na condição de professor de matemática da educação básica lecionando nas três séries do Ensino Médio da Escola Estadual Indígena de Ensino Fundamental e Médio Índio Antônio Sinésio da Silva, que fica localizada na aldeia Brejinho município de MarcaçãoPB, fez uso da Etnomatemática em sala de aula Esta pesquisa surgi do anseio em despertar o pensamento matemático, pensamento crítico dos alunos do Ensino Médio de uma escola Indígena, para mostrar como os alunos identificam os saberes matemáticos do povo Potiguara e seus conhecimentos informais. Sob o ponto de vista metodológico optamos por uma pesquisa qualitativa, pois não requer o uso de técnicas estatísticas para quantificar a pesquisa. Como resultados tivemos a satisfação de receber em mãos cinco excelentes trabalhos científicos de alunos do Ensino Médio, os trabalhos traziam todos os elementos que buscavamos coletar com os alunos, contendo os conhecimentos matemáticos de diferentes pessoas, agricultores plantadores de mandioca, agricultores plantadores de feijão, pescadores e agricultores plantadores de inhame. Todos os grupos conseguiram desenvolver os trabalhos, na socialização foi possível observar o quanto os alunos estavam alegres em conseguir atingir os objetivos dos trabalhos em superer suas barreiras seus obstáculos uma vez que esse foi o primeiro trabalho desenvolvido neste viés por esses alunos da $2^{\circ}$ série do Ensino Médio.

Palavras-chave: Etnomatemática, Ensino Médio, Teoria e prática. 


\section{INTRODUÇÃO}

O relato de experiência que é compartilhado através do VI Congresso Nacional de Educação- CONEDU, foi uma pratica pedagógica exitosa que aconteceu no ano de 2018. Um dos autores deste trabalho na condição de professor de matemática da educação básica lecionando nas três séries do Ensino Médio da Escola Estadual Indígena de Ensino Fundamental e Médio Índio Antônio Sinésio da Silva, que fica localizada na aldeia Brejinho município de Marcação-PB. Fez uso da etnomatemática, junto com três colegas do curso de matemática (coautores do trabalho), uma prática recorrente em suas aulas é o uso da etnomatemática, no entanto nesta turma foi mais além, foi sugerido que os alunos realizassem uma pesquisa a campo e escrevessem os resultados em formato de um pequeno artigo.

Desta forma foi apresentado para os alunos técnicas de coletas de dados, tipos de metodologia, o que é citação, tanto direta como indireta, enfim, os alunos tiveram aulas de metodologia do trabalho científico, uma vez que esse foi o primeiro contato que os alunos tiveram com esse tipo de trabalho, a pesquisa em campo consistia em identificar conhecimentos matemáticos de um agricultor, pescador, catadora de marisco, entre outro tipo de indivíduos do povo Potiguara etnia da qual os alunos dessa escola faz parte, uma análise que deveria ser feita a partir da visão dos alunos da $2^{\circ}$ série do Ensino Médio.

Esta pesquisa surgi do anseio em despertar o pensamento matemático, pensamento crítico dos alunos do Ensino Médio de uma escola Indígena, para mostrar como os alunos identificam os saberes matemáticos do povo Potiguara e seus conhecimentos informais.

As escolas indígenas do povo Potiguara da Paraíba "possuem um ensino diferenciado, voltado para a realidade da comunidade, levando em consideração os saberes tradicionais do povo, sua cultura, seu modo de vida, seus mitos e ritos, entre outros aspectos tradicionais desse povo milenar" (Gomes e Dias 2015, p.4).

Neste sentido a prática pedagógica tentou reafirma o ensino diferenciado que a escola possui buscando uma despertar nos alunos o pensamento matemático, o espírito de pesquisa acadêmica, a aproximação com a matemática formal e informal entre outras desenvolturas.

\section{METODOLOGIA}

Sob o ponto de vista metodológico optamos por uma pesquisa qualitativa, pois não requer o uso de técnicas estatísticas para quantificar a pesquisa. Segundo Silva e Menezes (2005) a pesquisa é considerada qualitativa quando:

Considerar que há uma relação dinâmica entre o mundo real e o sujeito, isto é, um vínculo indissociável entre o mundo objetivo e a subjetividade do sujeito que não pode ser traduzido em números. [...] não requer uso de métodos e técnicas estatísticas (Silva; Menezes, 2005, p. 20).

A presente pesquisa se caracteriza como uma pesquisa de método observacional uma vez que foi observado toda a realização das atividades realizadas pelos alunos. "Por um lado, pode ser considerado como o mais primitivo e, consequentemente, o mais impreciso. Mas, por outro lado, pode ser tido como um dos mais modernos, visto ser o que possibilita o mais elevado grau de precisão nas ciências sociais." (Gil, 2008, p. 16).

A pesquisa iniciou no primeiro semestre do ano de 2018 se estendeu até o segundo semestre do ano de 2018, no primeiro semestre aconteceu as primeiras aulas sobre formatação, digitação e o estudo sobre etnomatemática, após essas aulas os alunos escolheram os entrevistados e foram a campo fazer a pesquisa, cada qual elaborou um roteiro de perguntas para a entrevista, com a orientação do professor regente da disciplina de matemática e de três estudantes do curso de Licenciatura em Matemática, após a coleta dos dados foi realizada a escrita do trabalho e a socialização em sala de aula. A presente pesquisa passou por uma fundamentação teórica, análise dos dados e o processo de escrita dos resultados obtido através da prática pedagógica aplicada com os alunos da $2^{\circ}$ série do Ensino Médio. 


\section{DESENVOLVIMENTO}

Foi apresentado para os alunos trabalhos realizados nesta perspectiva (modelos), apresentando de forma intensiva o tema etnomatemática, assim como algumas ferramentas do word, uma vez que os alunos não tinham conhecimentos básicos de computação e digitação, essas aulas foram realizadas no laboratório de informática da escola.

A pratica pedagógica aconteceu no segundo semestre do ano de 2018, contou com 20 aluno matriculados na $2^{\circ}$ série do Ensino Médio, os alunos residem no município de Marcação, no entanto em aldeias diferentes e no centro da cidade, foram organizados cinco grupos de quatro alunos.

A Escola Índio Antônio Sinésio tem seu funcionamento durante os turnos da manhã, tarde e noite, oferece o Ensino do Infantil ao Ensino Médio, recebe aluno de todas as aldeias do município de Marcação inclusive os alunos do centro da cidade.

Os Parâmetros Curriculares Nacionais-PCN de Matemática assinalam para a necessidade de valorização da escola em aspectos multiculturais presentes na sociedade brasileira.

Para viver democraticamente em uma sociedade plural é preciso respeitar os diferentes grupos e culturas que a constituem. A sociedade brasileira é formada não só por diferentes etnias, como por imigrantes de diferentes países. Além disso, as migrações colocam em contato grupos diferenciados. Sabe-se que as regiões brasileiras têm características culturais bastantes diversas e a convivência entre grupos diferenciados nos planos social e cultural muitas vezes é marcada pelo preconceito e pela discriminação. 0 grande desafio da escola é investir na superação da discriminação e dar a conhecer a riqueza representada pela diversidade etnocultural que compõe o patrimônio sociocultural brasileiro, valorizando a trajetória particular dos grupos que compõem a sociedade. Nesse sentido, a escola deve ser local de diálogo, de aprender a conviver, vivenciando a própria cultura e respeitando as diferentes formas de expressão cultural (Brasil, 1997, p.32).

Neste sentido a prática pedagógica vem de encontro com a proposta curricular presente nos PCN, que incentiva o uso das riquezas culturais em volta da escola, assim a escola consegui ultrapassar os muros da escola fazendo uso de conhecimentos múltiplos dentro e fora da sala de aula.

\subsection{O QUE DE FATO É ETNOMATEMÁTICA?}

Criada pelo Professor Doutor Ubiratan D'Ambrosio, consistem em uma área da matemática que busca investigar o uso da Matemática, os conhecimentos matemáticos de diferentes tipos de grupos sociais ou indivíduos.

A palavra Etnomatemática em um contexto etimológico é explicado da seguinte forma por D’Ambrosio (1998, p. 5):

[...] etno é hoje aceito como algo muito amplo, referente ao contexto cultural, e, portanto, inclui considerações como linguagem, jargão, códigos de comportamento, mitos e símbolos; matema é uma raiz difícil, que vai na direção de explicar, de conhecer, de entender; e tica vem sem dúvida de techne, que é a mesma raiz de arte e de técnica. Assim, poderíamos dizer que etnomatemática é a arte ou técnica de explicar, de conhecer, de entender nos diversos contextos culturais. Nessa concepção, nos aproximamos de uma teoria de conhecimento ou, como é modernamente chamada, uma teoria de cognição.

Desta forma é possível ver que a etnomatemática é uma ótima possibilidade de prática pedagógica que pode ser aplicada em sala de aula, em especial em escolas indígenas com ensino diferenciado. "Etnomatematica possibilita uma interação entre os conhecimentos do aluno e os conhecimentos de sala de aula. Levando a uma aprendizagem de forma contextualizada mediante a ligação dos conteúdos formais da matemática e os saberes do cotidiano dos alunos" (Gomes, 2019, p.22)

O autor Marchon, define a etnomatemática como sendo: 
A Etnomatemática, [...] território múltiplo e de difícil compreensão; "e uma região formada por uma pluralidade de caminhos que deixam abertas possibilidades ainda inexploradas para a pesquisa teórica. É, sem dúvida uma região a ser interrogada e explorada (filosoficamente, sociologicamente etc.) Marchon (2016, p.28).

Foi nesta perspectiva que aconteceu o referido estudo usamos de teoria e prática para uma melhor obtenção dos resultados.

\subsection{POVO POTIGUARA DA PARAÍBA E A EDUCAÇÃO ESCOLAR INDÍGENA}

Para iniciar um diálogo sobre a educação escolar indígena e a cultura indígena se faz necessário um recorte histórico, uma volta ao século XVI, um fator transformador de grande impacto para os povos indígenas do Brasil.

Antes da formulação de leis que tratam oficialmente da educação escolar indígena, em meados do século XVI, a mesma era oferecida pelos jesuítas, pautada na catequização, civilização e integração forçada dos índios à sociedade nacional. Este sistema educacional negava a identidade indígena e tentava transformar os índios em seres diferentes do que eram. (Faustino, 2001, S/P).

Desta forma foi grande as transformações que os indígenas passaram depois da chegada dos portugueses em solo brasileiro, os povos potiguaras, sofreram influencias dos não indígenas, foram obrigados a não falar a língua materna, a se comporta como os não indígenas, no entanto eles resistiram, lutaram, muitos morreram nesta batalha não se sabe ao certo quantos eram os potiguaras quando aqui os portugueses chegaram.

Mesmo diante de tantas imposições da sociedade com os indígenas em relação ao cultivo da cultura indígena Potiguara Nascimento e Barcellos (2012) definem que:

[...]nos últimos séculos o povo Potiguara vem sofrendo influência de outros povos, desde a chegada dos portugueses, porém não perderam suas características e suas tradições e ainda hoje cultivam seus costumes e seus valores de origens, como as pinturas feitas em seus corpos, além de outras expressões culturais como o ritual do toré. (Nascimento e Barcellos, 2012, p.21).

Segundo Barcellos (2012) os Potiguara têm população de aproximadamente, 20.000 mil indígenas, que vivem num território de 33.757 hectares, distribuídos em três áreas contíguas nos municípios de Marcação, Baía da Traição e Rio Tinto, no Litoral Norte do Estado da Paraíba. Os Potiguara atualmente, contam com 33 aldeias presentes nos 3 municípios, cada aldeia possui um líder que é chamado de Cacique. 


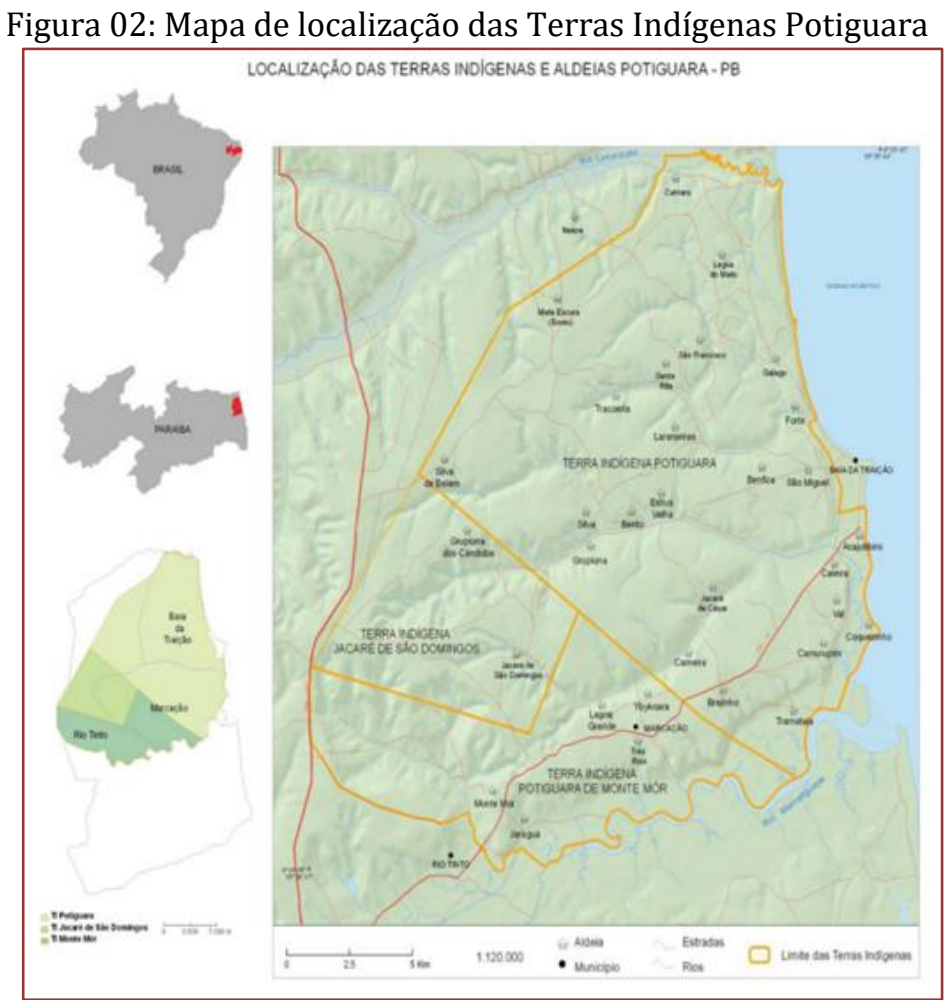

Fonte: Cardoso e Guimarães (2012).

\section{RESULTADOS E DISCUSSÃO}

Como resultados destacamos a interação dos alunos em realizar a pesquisa a campo em escrever os resultados com fundamntação teórica, baseada em obras bibliografica que foram destribuidas entre os alunos.

Todos os grupos conseguiram desenvolver os trabalhos na socialização foi possível observar o quanto os alunos estavam alegres em conseguir atingir os objetivos dos trabalhos em superer suas barreiras e seus obstáculos, uma vez que esse foi o primeiro trabalho desenvolvido neste viés por esses alunos da $2^{\circ}$ série do Ensino Médio.

Foram realizadas uma pesquisa com um pescador (catador de carangueijo), e quatro agricultores, sendo dois plantadores de mandioca, um plantador de feijão e um plantador de milho.

Nos trabalhos dos alunos constava introdução, contendo objetivos e justificativa; metodologia aplicada; embasamento teórico, contendo biografia utilizada; desenvolvimento contendo a realização do trabalho; resultados e discussão destacando a matemática utilizada pelos seus intrevistados.

\section{CONSIDERAÇÕES FINAIS}

Como resultados tivemos a satisfação de receber em mãos cinco excelentes trabalhos científicos de alunos do Ensino Médio, os trabalhos traziam todos os elementos que buscavamos coletar com os alunos, contendo os conhecimentos matemáticos de diferentes pessoas, agricultores plantadores de mandioca, agricultores plantadores de feijão, pescadores e agricultores plantadores de inhame.

Os trabalhos foram ainda socializados entre os alunos, uma experiência única vivenciada por essa turma, que além de criar um pensamento crítico, conheceram e praticaram as normas técnicas da Associação Brasileira de Normais Técnicas- ABNT.

A experiência serviu como inspiração para futuras pesquisas e metodologia para ser aplicada em sala de aula nesta perspectiva, surgindo um vasto campo de atuação para professores e pesquisadores nesta área da Matemática. 


\section{REFERÊNCIAS}

[1] Brasil. Secretaria de Educação Fundamental. Parâmetros Curriculares Nacionais: pluralidade cultural terceiros e quarto ciclos do ensino fundamental. Versão preliminar para discussão nacional, Brasília: MEC/SEF, 1997

[2] barcellos, Lusival. Práticas educativo-religiosas dos indígenas Potiguara da Paraíba. João Pessoa: Editora da UFPB, 2012.

[3] Cardoso, T.M. e Guimarães, G. (orgs.). Etnomapeamento dos Potiguara da Paraíba. Brasília: FUNAI/CGMT/ CGETNO/CGGAM, (Série Experiências Indígenas, n.2), 2012.

[4] D’ámbrosio, Ubiratan. Etnomatemática: arte ou técnica de explicar e conhecer. 4.ed. São Paulo: Ática, 1998

[5] Faustino, R. C. Políticas educacionais e educação escolar indígena no Paraná. Universidade Federal de Santa Catarina: [201-?]. Disponível em: http://www.rizoma.ufsc.br/pdfs/936-of10b-st3.pdf. Acesso em jun de 2018.

[6] Gil, A. C. Métodos e técnicas de pesquisa social. 6. ed. São Paulo: Atlas, 2008.

[7] Gomes, Leonardo Cinésio; Formas geométricas: visualização e identificação através de pinturas corporais indígenas. Trabalho de Conclusão do Curso Licenciatura em Matemática Universidade Federal da Paraíba, UFPB. Rio Tinto-PB, 2019.

[8] Gomes, Leonardo Cinésio; DIAS, Graciana Ferreira. Prática Docente e Etnomatemática: Uma Investigação nas Aldeias Potiguara Da Paraíba. Anais do II CONEDU Congresso Nacional de Educação, Campina Grande-PB. 2015.

[9] Marchon, Fabio Lennon. Educação Matemática e Etnomatematica: Entrelaçamento e possibilidades filosóficas, Curitiba, 2016.

[10] Nascimento, José Mateus do; Barcellos, Lusival. O povo Potiguara e a luta pela etnicidade. In: Nascimento, José Mateus do (Org.). Etnoeducação Potiguara Pedagogia da Existência e das Tradições. João Pessoa: Ideia, p. 11-25, 2012.

[11] Silva, E. L.; Menezes, E. M. Pesquisa e suas classificações. 4. ed. Florianópolis: UFSC, 2005. 


\title{
Capítulo 2
}

Equidade avaliativa servida à mesa: A "Gastromática" como uma proposta metodológica ativa para o ensino e avaliação da Etnomatemática

\author{
Edivan Vieira Lima \\ Sheila Pires dos Santos \\ Solimar Barros Ramirees
}

Resumo: Quando cria-se um elo entre a matemática e a antropologia, assim como a geografia e a sociologia, pode-se construir a etnomatemática, que envolve as diferentes culturas considerando suas raízes e tensões sociais, diferente da matemática pura, que considera essencial, apenas as habilidades cognitivas, o que não deixa de ser importante, porém, por serem pouco dinâmicas, não realiza uma conexão com o cotidiano, fazendo com que os alunos não assimilem a maior parte dos conteúdos, tornando as aulas mecânica e pouco satisfatória quando relacionada a índices de proficiência. Na tentativa de dinamizar tais aulas, desenvolveu-se um projeto teórico/prático, que considerou além dos conteúdos da disciplina, um enfoque histórico-cultural. Dessa maneira, as aulas teóricas abrangeram conhecimentos prévios, termos técnicos, matemática financeira básica, cálculo de proporções, e características étnicas, já as aulas práticas, destinou-se ao preparo de alimentos que estabelecesse uma assimilação do conteúdo tanto de matemática quanto das considerações histórico-culturais. 0 projeto da cozinha experimental de matemática foi de grande valia na fixação dos conteúdos relacionados a frações, proporções e as quatro operações básicas. 0 professor juntamente com os alunos prepara receitas envolvendo diferentes classificações de medidas proporcionando um momento de aprendizado dinâmico e qualitativo. A possibilidade de desenvolvimento de projetos à parte das disciplinas da Base Comum, melhora o convívio entre professores/alunos, alunos/alunos, pois favorece a composição de grupos com indivíduos de diferentes idades e identidades pessoais, melhorando o entendimento das diferentes opiniões.

Palavras-chave: Matemática, Etnomatemática, Cozinha experimental, avaliação. 


\section{INTRODUÇÃO}

Há indícios de que a matemática desenvolveu-se por volta dos séculos VIII e IX a.C, entre os babilônios e os Egípcios, tornando-se ciência, no sentido moderno da palavra, a partir dos séculos V e VI a.C., na Grécia. Intensificou-se ainda mais no período da Renascença, devido a novas descobertas científicas que perduram até os dias atuais.

A partir de registros arqueológicos, nota-se que a matemática além de ciência acadêmica, é um fator cultural e parte histórica do desenvolvimento da espécie humana, pois são partes de uma mesma evolução pura e contínua. Argumenta-se o fato, através da obra "Os Elementos" de Euclides, escrito a aproximadamente 300 anos a. C.

Em contextos mais atuais, Skovsmose e Vithal (1997), consideram a matemática uma das maiores descobertas do ser humano que alimenta a educação. Já para Huppes e Brum (2010/2011) o ensino da área constitui-se em uma temática a ser analisada de forma cuidadosa para evitar assimilação intuitiva, por tratar-se de uma ciência constante no cotidiano, ainda assim, como consta nas Diretrizes Curriculares do Estado do Paraná, é necessário que o seu ensino comtemple estratégias que permitam ao educando construir sentido e significado às ideias expostas (PARANÁ, 2008, p 45)

Quando cria-se um elo entre essa disciplina e a antropologia, assim como a geografia e a sociologia, podese construir a etnomatemática, que envolve as diferentes culturas considerando suas raízes e tensões sociais, diferente da matemática pura, que considera essencial, apenas as habilidades cognitivas, o que não deixa de ser importante, porém deve-se levar em consideração que não é único.

Pedagogicamente pode-se afirmar que a etnomatemática trabalha com situações reais do tempo e do espaço, passando a ser praticada por grupos culturais, intensificando a parte prática da disciplina, criando uma assimilação com o cotidiano, consolidando o conhecimento e trazendo sentido para a parte teórica, que é indispensável, mas que aliada a prática, constrói novos conhecimentos e experiências.

No desenvolvimento de um projeto que envolve a etnomatemática, o educador tem o papel de gerenciar, facilitar e da interagir aluno/aluno, processo que não é difícil de ocorrer quando mistura-se teoria e prática, ainda mais que esta, ocorre em um ambiente como a cozinha. Utilizar-se da culinária para desenvolvimento de habilidades voltadas à parte teórica dos conteúdos matemáticos, fortalece o processo de ensino aprendizado, tornando-o mais qualitativo, além de ser prazeroso, auxiliando na memorização e satisfação pessoal, favorecendo a autoestima, considerada fundamental para o progresso do estudante tanto academicamente, quanto como pessoa.

É muito comum ouvirmos dos alunos o quanto é difícil aprender matemática, essa afirmação nos traz algumas inquietações: 0 que é aprender matemática e quando esse aprendizado é significativo?

A matemática constitui-se em uma temática que deve analisada cuidadosamente, pois é uma área do universo humano que interage com diversas situações do cotidiano, sendo possível assim assimilar conteúdos de forma intuitiva.

Com base no Sistema Huppes de aprendizado que determina, desenvolvimento e aperfeiçoamento do processo de ensino/aprendizagem, trazendo o conhecimento secular do aluno para facilitar a implementação dos conteúdos matemáticos em seu aprendizado, tornando assim acessível e de forma prazerosa para o educando e o educador.

Desenvolver raciocínio logico, resolutividade de situações problemas, interação social, com ambiente diferenciado trabalhando questões regionais.

\section{METODOLOGIA}

Na tentativa de dinamizar as aulas, desenvolveu-se um projeto teórico/prático, onde dividi - se parte das aulas em sala, proporcionando conhecimento prévio de termos matemáticos técnicos, levantamento de custo, e cálculo de proporções, e ora, na cozinha afim de estabelecer assimilação da teoria com a prática. 
Na primeira aula foi ensinado a confecção de ficha técnica. As aulas a posteriori foram ministradas de acordo com os fundamentos matemáticos dos quais seriam utilizados para produção e desenvolvimento das habilidades práticas. Pode -se destacar como conteúdos primordiais das aulas, o levantamento de custo para produção das receitas, comparação de valores no comércio local considerando marca e qualidade dos produtos, e cálculo de proporções onde os alunos deveriam trabalhar matematicamente as quantidades utilizadas necessárias para cada receita, por pessoa e por grupos maiores de pessoas. Segue exemplo de uma aula de proporcionalidades:

A receita padrão deve ser alterada para que os alunos possam visualizar quando se deve aumentar ou diminuir a quantidade de pessoas ou ingredientes de forma proporcional. Relacionar a matemática e a cozinha é que diversas receitas utilizam em seus processos números fracionários, como: 1/2 (meia xícara), ou 1/3 (um terço do copo americano) entre outras medidas. A adição são aplicadas no processo e podemos ver na receita a seguir:

Tabela 1-Ingredientes para 30 porções de pão de queijo

\begin{tabular}{|c|c|}
\multicolumn{1}{|c|}{ Ingredientes } & Quatidades \\
\hline Óleo de Soja & $1 / 2$ Copo \\
\hline Leite & 1 Copo \\
\hline Ovos & 4 Unidades \\
\hline Queijo Meia Cura & $250 \mathrm{G}$ \\
\hline Polvilho Doce & $1 / 2 \mathrm{~kg}$ \\
\hline Sal & 1 Colher Sobremesa \\
\hline
\end{tabular}

A receita padrão foi sugerida aos alunos para que trocassem as porções para que os mesmos visualizassem a redução dos ingredientes proporcionalmente.

Tabela 2 - Ingredientes para 15 porções de pão de queijo

\begin{tabular}{|c|c|}
\hline \multicolumn{1}{|c|}{ Ingredientes } & Quatidades \\
\hline Óleo de Soja & $1 / 2$ Copo Óleo \\
\hline Leite & $1 / 2: 2=1 / 4$ \\
\hline Ovos & $4: 2=2$ Unidades \\
\hline Queijo Meia Cura & $250: 2=125 \mathrm{G}$ \\
\hline Polvilho Doce & $1 / 2: 2=1 / 4$ ou $250 \mathrm{G}$ \\
\hline Sal & $1 / 2$ Colher Sobremesa \\
\hline
\end{tabular}

Para contemplar a geografia, foram escolhidos alguns alimentos de regiões diferentes, das quais se trabalhou a regionalização local, como formação cultural, religião, dança, música, aspectos físicos, climáticos, vegetação e consequente alimentação local.

Após contextualização as aulas passaram a ser práticas, sendo dividas em: Comportamento à mesa (regras de etiqueta à mesa);

Comportamento no setor de trabalho (regras de comprometimento e responsabilidade coletiva na cozinha);

Segurança no ambiente de trabalho (EPIs e Equipamentos de Segurança);

Limpeza do ambiente e do indivíduo (regras de higienização do local de trabalho e higienização própria);

Para as aulas voltadas à culinária, os alunos foram divididos em quatro grupos, onde cada grupo desenvolveria uma receita relacionada ao mesmo tema predeterminado para o dia. Era estipulado um tempo (de acordo com o tema) para termino e entrega da refeição, os grupos apresentavam o prato a uma banca formada por funcionários da escola (sem repetição de pessoas na banca para evitar vínculo de afetividade com algum grupo). 
Na apresentação era necessário fazer um resumo da produção completa desde ingredientes, até modo e tempo de preparo. Era avaliado ainda, o designe dos pratos. Ao final os jurados escolhiam em conjunto, um único grupo, que seria considerado vencedor por eles, levando em consideração requisitos como: explicação clara e objetiva, textura, sabor e consistência do alimento, designe e organização do preparo do prato no geral. Tais regras foram baseadas no "Master Cheff".

Os Temas pré determinados eram em alguns momentos contextualizados com aulas de geografia, os professores através das receitas escolhidas, determinaram as regiões as quais caberiam tais pratos, enfatizando a cultura regional do local, além de exemplificar em algumas aulas, pratos típicos de algumas regiões. Na prática as receitas variavam de fáceis à difíceis, desde a escolha do ingrediente até a forma e o tempo de preparo, que caberiam dentro do tempo das aulas (1h50min), incluído apresentação. 0 grau de dificuldade de receitas aumentavam proporcionalmente a experiência no manuseio dos equipamentos da cozinha.

\section{DESENVOLVIMENTO}

Para que se consiga resolver qualquer situação cotidiana, seja individual ou coletivamente, o homem precisa estabelecer relações com a história, observá-la para que possa criar, recriar ou dinamizar algo chegando ao foco de melhorar aquilo que já existe. (D’AMBROSIO, 2005; FREIRE, 1980).

A matemática está presente em diferentes contextos, seja na construção civil, na ida ao supermercado, dentro dos hospitais, farmácias ou na escola, e é sabido, que o entendimento disso é essencial para a vida do indivíduo, ou seja, ela não deve ser pura, não deve considerar apenas símbolos, ela vai muito além de cálculos.

Isso fez com que um grupo de pesquisadores, incluíndo um brasileiro, considerasse a matemática em âmbitos históricos e filosóficos, que deve buscar desde a sobrevivência até a transcendência, sem restringir-se apenas em técnicas. (D’AMBRÓSIO, 2018)

Nas décadas de 70 e 80, passou avaliar a possibilidade de coexistir uma disciplina chamada de etnomatemática, que tem como foco os saberes matemáticos entrelaçados a cultura e ao comportamento humano, tornando-se transdisciplinar pois objetiva um ensino a partir de métodos de pesquisa, cognição, antropologia, história e sociologia. (KNIJNIK; WANDERER; GIONGO; DUARTE, 2012)

Toda a proposta foi inspirada em Jean Piaget, Lev Vygostsky entre outros, que defendem a ideia de que as emoções e tomadas de decisões resultam tanto de processos cognitivos quanto de processos emocionais e sociais, e as escolas passam a ser esse local de sistematização do conhecimento e sua evolução, possibilitando a consciência da realidade no constante processo de aprendizagem (PARANÁ, 2008).

Unir a etnomatemática com a culinária, além de trabalhar tudo o que se espera dessa nova abordagem disciplinar, ainda desenvolve estratégias metodológicas ativas, que contribuem para a formação integral do aluno, ou seja, o professor passa a gerenciar e facilitar o processo de ensino e aprendizagem, de modo que os conhecimentos trazidos pelos educandos integrem o conteúdo, tornando-o crítico em relação as experiências cotidianas (D’AMBROSIO, 2011, p.80).

0 professor de matemática como mediador, se torna responsável por buscar estratégias que superem as habilidades fragilizadas dos alunos em relação a disciplina, que muitas vezes é vista como algo desintegrado da realidade, e unifica-la com a culinária já é uma proposta reconhecida por alguns pesquisadores, como pode-se citar a produção de chimangos por PAIVA (2012) que uniu a etnomatemática com a cozinha, ou então RAMOS (1998), que ensinou frações exemplificando a divisão de uma pizza em partes iguais.

Baseando-se em tais propostas, intensificou-se a busca por esta metodologia e o entendimento de sua aplicabilidade, pois concretiza-se o alcance dos objetivos a partir dos pressupostos teóricos estudados até então. 


\section{RESULTADOS E DISCUSSÃO}

Através das aulas teórico/práticas os alunos melhoraram o desempenho em sala de aula e em avaliações diagnósticas. Por ser um público diversificado entre as turmas de ensino médio, e pelo fato de ser um trabalho em grupo, os alunos apresentaram melhor convívio dentro da escola, sendo mediadores na resolução de situações problemas, e conscientização de outros educandos nos casos de bullying, pois passaram a ter um conhecimento melhor em relação a culturas de diferentes regiões, e o quanto as mesmas podem influenciar na construção de conceitos pré determinados, relacionados a diversas situações.

Ao questionar o aluno quanto a aceitação das aulas, podemos notar a mudança de opinião sobre as aulas de matemática, das quais os alunos mostram-se mais interessados e empenhados, já que através do projeto puderam perceber a importância do conhecimento da disciplina no dia a dia.

A alegação até então, taxava-se o fato de que nem todos dariam, pelo menos, logo que em sequência, continuidade aos estudos após o termino do ensino médio, dando a eles a impressão de que os conteúdos trabalhados em sala, restringiam-se no preparo acadêmico dos mesmos para avaliações externas, como o Exame Nacional do Ensino Médio e Vestibulares.

Ao perceberem que os conteúdos também contemplam utilidades do próprio cotidiano, como o preparo de um alimento, o educando passou a participar ativamente das aulas e apresentarem melhoras no desempenho, como pode-se comprovar a partir de suas notas.

Vale destacar ainda, que as eletivas proporcionaram uma forma diferença na relação professor/aluno, o que melhorou a convivência dentro da Instituição, tornando-a mais harmoniosa e criando um elo de afetividade, o que intensificou a confiança dos alunos à seus educadores, amenizando possíveis problemas sociais e melhorando o processo de ensino/aprendizagem.

A avaliação é um importante instrumento no processo de ensino-aprendizagem, uma vez que, conforme salienta Luckesi (2005) em Avaliação da Aprendizagem Escolar, esta, deve subsidiar decisões em prol da melhoria do processo de ensino e aprendizagem. Dessa forma, o ato de avaliar deve, não apenas estar inserido no processo de educação mas, principalmente, contribuir para seu pleno desenvolvimento.

\section{CONSIDERAÇÕES FINAIS}

A possibilidade de desenvolvimento de projetos à parte das disciplinas da Base Comum, melhorou o convívio entre professores/alunos, alunos/alunos, pois favorece a composição de grupos com indivíduos de diferentes idades e identidades pessoais, melhorando o entendimento das diferentes opiniões. A relação entre educador e educando também apresenta melhora, pois o projeto permite uma proximidade maior entre os mesmos, tirando assim, a referência hierárquica do professor como detentor da totalidade do conhecimento.

Assim pode-se concluir que as disciplinas eletivas, são necessárias tanto para o desenvolvimento acadêmico, devido a abordagem dos conteúdos que na maioria dos projetos ocorrem de forma interdisciplinar, como para formação pessoal, na qual se destaca a aceitação na diversidade de ideias e na formação crítica do indivíduo que passa a saber a diferença entre opinar, argumentar e julgar a posição de cada um.

\section{REFERÊNCIAS}

[1] Brasil. Ministério da Educação. Parâmetros curriculares para o Ensino Médio: Ciências da Natureza, Matemática e suas tecnologias. Brasília, 2000.

[2] Brasil. Ministério da Educação. Parâmetros curriculares para o Ensino Médio: Ciências Humanas e suas tecnologias. Brasília, 2000.

[3] Brasil. Ministério da Educação. Parâmetros curriculares para o Ensino Médio: Linguagens, códigos e suas tecnologias. Brasília, 2000.

[4] D’Ambrosio, U. Etnomatemática: Elo entre as tradições e a modernidade. 2. Ed., Belo Horizonte: Autêntica, 2002. 
[6] __ Etnomatemática: elo entre as tradições e a modernidade. 2. ed. Belo Horizonte: Autêntica, 2005.

[7] __ Educação matemática: da teoria a prática, 22. ed. Campinas , Papirus, 2011.

[8] _ Mathematical Modelling in Education Research and Practice: Cultural, Social and Cognitive Influences. In: Stillman, G. A.; Blum, W.; Biembengut, M. S. (Ed.) International Perspectives on the Teaching and Learning of Mathematical Modelling. S. l.: Springer International Publishing AG, 2018.

[9] Freire, P. Conscientização: teoria e prática da libertação: uma Introdução ao pensamento de Paulo Freire. 3. ed., São Paulo:Moraes, 1980.

[10] Huppes, J.C.; Brum, M. D. A. Matemáticas na Cozinha. II Escola de Inverno de Educação Matemática, 2010.

[11] Huppes, J.C.; Brum, M. D. A. Prática Social da Culinária na perspectiva do Programa Etnomatemática. XIII Conferência Interamericanda de Educação Matemática, Recife, 2011.

[12] Knijnik, G.; Wanderer, F.; Giongo, I. W.; Duarte, C. G. Etnomatemática em movimento. Belo Horizonte: Autêntica, 2012.

[13] Paraná. Secretaria De Estado Da Educação. Diretrizes curriculares da educação básica: matemática. Curitiba: SEED, 2008.

[14] Paiva, T.V.S.et al. A matemática na culinária regional. In:III EIEMAT -Escola de Inverno da Educação Matemática. 1o Encontro Nacional PIBID-Matemática, Agosto de 2012. Santa Maria -RS. Anais...Disponível em: <http://w3.ufsm.br/ceem/eiemat/Anais/arquivos/RE/RE_Paiva_Tatiana.pdf>. Acesso em: 01/06/2019.

[15] Ramos, L. F. Frações sem mistérios. São Paulo:Ática, 1998.

[16] Skovsmose, 0.; Vithal, R. The end of innocence: a critique of 'ethnomathematics'. Educational Studies in Mathematics, New York: v. 34, p.131-158,1997. 


\section{Capítulo 3}

Ensino de Geometria da Teoria a Práxis: Contribuições para a prática pedagógica do professor de Matemática

\section{Vania de Moura Barbosa Duarte}

\section{Marcos Antônio Heleno Duarte}

Resumo: Pesquisas no campo da Didática da Matemática possibilitam compreender a natureza do trabalho didático, bem como as transformações porque passam os conteúdos ensinados na escola e quais os recursos que propiciam a Transposição Didática destes conteúdos, no caso em foco o ensino de Geometria Plana nos anos finais do ensino fundamental. Com relação ao ensino da Matemática a Geometria aparece como um campo privilegiado (apesar de não ser o único) para exercitar as inter-relações entre o método lógico-dedutivo e o raciocínio intuitivo, apoiado nas representações materiais dos objetos abstratos da geometria. Diante desse aspecto iremos apresentar neste artigo uma experiência relacionada ao desenvolvimento de uma atividade vivenciada (oficina) na Semana da Matemática de uma Universidade Pública de Pernambuco que constou de estudos e reflexões teóricas voltadas a práxis para o ensino de geometria, embasados na teoria das Situações Didáticas de Brousseau (1996).Nesse enfoque, a metodologia utilizada no projeto foi numa perspectiva qualitativa de estudo de caso conforme Gil (2008) que consiste no estudo profundo e exaustivo de um ou poucos objetos, de maneira que permita seu amplo e detalhado conhecimento. Constou de estudos e atividades voltados à apreensão e/ou reconstrução do conhecimento geométrico, trabalhados nos componentes curriculares de Didática e Estágio Supervisionado. Com esta atividade procuramos promover contribuições para a futura prática pedagógica do professor de matemática. Para tanto a referida oficina utilizou-se do jogo Teorema de Pitágoras 1 na perspectiva de que o uso de materiais didáticos manipuláveis auxiliam a construção de conceitos geométricos. Desta forma apresentaremos neste artigo parte da sistematização da vivência do projeto realizado.

Palavras-chave: Ensino de Geometria; Teoria e prática; Situações Didáticas. 


\section{INTRODUÇÃO}

Atualmente parece existir certo consenso a respeito de que a prática pedagógica não se limita à transformação e à apreensão de conhecimentos, mas a concepção de ensino do professor permeada pelos recursos que auxiliam a sua prática e das abordagens teóricas que promovem reflexões e mudanças metodológicas.

Com relação ao ensino da Matemática a Geometria aparece como um campo privilegiado (apesar de não ser o único) para exercitar as inter-relações entre o método lógico-dedutivo e o raciocínio intuitivo, apoiado nas representações materiais dos objetos abstratos da geometria.

Temos conforme explicita os relatórios de avaliações de larga escala em Matemática como SAEB e mais especificamente SAEPE no estado de Pernambuco que os estudantes da educação básica apresentam dificuldades relacionadas à aprendizagem de conceitos geométricos tornando necessária a busca por novos métodos e materiais para o ensino de geometria visando à aprendizagem dos estudantes.

Diante destes fatos, neste artigo estamos interessados em explicitar aspectos desenvolvidos num projeto que promoveu estudos teórico e prático voltado ao ensino de geometria nos anos finais do ensino fundamental com estudantes da disciplina de didática da matemática e de estágios supervisionados de um curso de licenciatura em matemática, ressaltando que em se tratando de sala de aula, muitos questionamentos despontam. Inicialmente o que ensinar? Posteriormente, como ensinar?

Para responder a estas perguntas se faz necessário adentrar no âmbito da Didática da Matemática, área de investigação no processo de ensino e de aprendizagem dos conceitos da Matemática que surge a partir da década de 60, quando da criação dos Institutos de Pesquisa em Educação Matemática (IREM) na França.

Temos também segundo Fainguelernt (1995), a Geometria desempenha um papel fundamental porque ativa as estruturas mentais de abstração e generalização; é tema integrador entre as diversas partes da Matemática, sendo a intuição, o formalismo, a abstração e a dedução constituintes de sua essência.

Sabemos que a Didática da Matemática se apresenta como um campo fértil para estudos e pesquisas tanto com relação à sala de aula quanto ao ensino e aprendizagem, buscando apoio nas teorias de Guy Brousseau (1996), Yves Chevallard (1991), dentre outros, que tratam de fenômenos como Contrato Didático/Situações Didáticas e Transposição Didática, respectivamente.

Contudo é interessante que aqui se enfatize, qual a definição de Didática da Matemática. Conforme destacado por Pais (2001, p.11).

A didática da Matemática é uma das tendências de grande área de educação matemática, cujo objeto de estudo é a elaboração de conceitos e teorias que sejam compatíveis com a especificidade educacional do saber escolar matemático, procurando manter fortes vínculos com a formação de conceitos matemáticos, tanto em nível experimental da prática pedagógica, como no território teórico da pesquisa acadêmica.

Nesse contexto, pesquisas no campo da Didática da Matemática, possibilita compreender a natureza do trabalho didático, bem como as transformações porque passam os conteúdos ensinados na escola e quais os recursos que possibilitam a Transposição Didática destes conteúdos.

Partindo desse enfoque, temos uma primeira definição de Transposição Didática, explicitada por Chevallard (1991, p. 45):

Um conteúdo do conhecimento, tendo sido designado como saber a ensinar sofre então um conjunto de transformações adaptativas que vão torná-lo apto a tomar lugar entre os objetos de ensino. 0 "trabalho" que, de um objeto do saber a ensinar faz em objeto de ensino, é chamado de transposição didática.

Temos também dentro do campo da Didática da Matemática de acordo com Lorenzato (2006) que refletir sobre a utilização de material didático manipulável (MD) no ensino de Matemática é de suma importância para os cursos de formação de professores, uma vez que são nestes cursos de formação que os professores deverão aprender a utilizar corretamente os materiais manipuláveis explorando os conceitos de cada assunto abordado. Palavras não alcançam o mesmo efeito que conseguem os objetos ou imagens, estáticos ou em movimentos, palavras auxiliam, mas não são suficientes para ensinar (Lorenzato, 2006). 
Ainda nesse enfoque os Parâmetros Curriculares de Matemática do Estado de Pernambuco para o Ensino fundamental destacam que vários aspectos têm sido apontados como pedagogicamente relevantes nas experiências com jogos na sala de aula de Matemática:

Em primeiro lugar, menciona-se a necessidade de ampliar a dimensão lúdica, importante para o desenvolvimento integral do estudante.

Em segundo lugar, argumenta-se que ideias e relações matemáticas importantes estão presentes numa enorme variedade de jogos e por meio deles é possível um encontro inicial e estimulante com essas ideias. Eles constituem uma forma interessante de lidar com problemas, pela possibilidade de serem propostos de modo atrativo, favorecendo a criatividade na elaboração de estratégias de resolução e na busca de soluções.

Além disso, a busca de estratégias para a vitória ou para solucionar um desafio inclui, via de regra, uma variedade de questões de lógica ou de Matemática das elementares aos problemas não resolvidos por especialistas. Este fato possibilitaria a exploração de um mesmo jogo em diversos níveis, dependendo do estágio dos participantes.

Outro aspecto a ressaltar é o de que muitos dos jogos propiciam a integração de várias áreas da Matemática - aritmética, álgebra, geometria, combinatória etc -, o que tem sido uma das mais ricas características dessa ciência.

Também é mencionada a compatibilidade entre o trabalho pedagógico com jogos e a metodologia de resolução de problema. Os jogos matemáticos fornecem uma excelente oportunidade para que sejam explorados

Além do aspecto interativo. (Pernambuco, 2012, p. 36-37)

\section{METODOLOGIA}

Neste âmbito a metodologia utilizada no projeto foi numa perspectiva qualitativa de estudo de caso conforme Gil (2008) que consiste no estudo profundo e exaustivo de um ou poucos objetos, de maneira que permita seu amplo e detalhado conhecimento. Constou de estudos e atividades voltadas à apreensão e/ou reconstrução do conhecimento geométrico, nos componentes curriculares de Didática e Estágio Supervisionado, sendo estas disciplinas parte do programa do referido curso, constando no seu plano de ensino atividades teórico e experimentais, no campo geométrico com o auxílio de materiais manipuláveis para serem utilizados na construção de conceitos geométricos do ensino fundamental anos finais de acordo com os Parâmetros para a Educação Básica do Estado de Pernambuco (2012).

O público alvo foram estudantes das disciplinas de Didática e Estágio Supervisionado do curso de Matemática $1^{\text {o }}$ e $2^{\circ}$ semestre de 2017 e as atividades a serem desenvolvidas de acordo com o projeto seriam oficinas práticas para discussão e elaboração de materiais didáticos voltados ao ensino de geometria nos anos finais. Dentre as oficinas realizadas explicitaremos a seguir uma das atividades que foi desenvolvida na Semana da Matemática 2017 do curso de Licenciatura em Matemática com o tema Didática da Matemática: o olhar na Geometria Plana anos finais, que constou da vivência de uma proposta didática com o Teorema de Pitágoras 1. Embasada nos Parâmetros Curriculares de Matemática do Estado de Pernambuco para o Ensino fundamental (2012, p.94) onde,

as atividades de ampliação e de redução de figuras vão permitir consolidar a ideia de semelhança, iniciada na etapa anterior. 0 estudante já deverá ser capaz de identificar os elementos que não se alteram e aqueles que se modificam, em atividades de ampliação e redução. A consolidação dessas ideias irá permitir, nos últimos anos dessa etapa, a compreensão dos Teoremas de Tales e de Pitágoras, bem como suas aplicações em problemas relacionados ao contexto social do estudante (pág.94).

A proposta para a atividade didática foi norteada na Teoria das Situações Didáticas de Guy Brousseau. Como um dos pioneiros da Didática da Matemática, ele desenvolveu essa teoria para compreender as relações que acontecem entre alunos, professor e saber em sala de aula e, ao mesmo tempo, propor situações que foram experimentadas e analisadas cientificamente. 
Para modelar a teoria das Situações Didáticas, Brousseau (1996) propõe o sistema didático stricto sensu ou triângulo didático (figura 1), que comporta três elementos - o aluno, o professor e o saber - que são partes constitutivas de uma relação dinâmica e complexa - a relação didática - que leva em consideração as interações entre professor e alunos (elementos humanos), mediadas pelo saber (elemento não-humano), que determina a forma como tais relações irão se estabelecer.

\section{Figura 1}

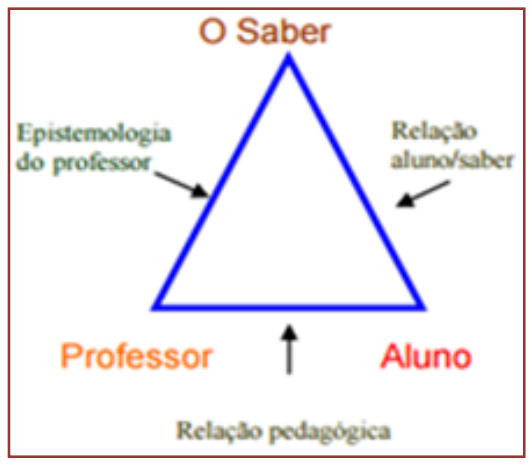

\section{A TEORIA DAS SITUAÇÕES DIDÁTICAS}

Baseia-se no princípio de que "cada conhecimento ou saber pode ser determinado por uma situação", entendida como uma ação entre duas ou mais pessoas. Para que ela seja solucionada, é preciso que os alunos mobilizem o conhecimento correspondente. Um jogo, por exemplo, pode levar o estudante a usar o que já sabe para criar uma estratégia adequada.

Como seria esta teoria?

Brousseau (2007) enfatiza que as situações de ensino devem ser criadas pelo professor, de modo a aproximar o aluno do saber do qual ele deve se apropriar. Para isso, cabe ao docente fazer um duplo papel cíclico:

- Procurar situações onde os alunos possam dar sentido ao conhecimento, através da contextualização e personalização do saber, num movimento de vivenciar o conhecimento pelo aluno.

- Ajudar seus alunos no sentido inverso, ou seja, descontextualizando e despersonalizando os conhecimentos, como fazem os matemáticos, de modo a tornar as produções dos alunos fatos universais e reutilizáveis.

Papel Ativo do aluno diante de uma situação, Brousseau (1996) destaca que para aprender, o aluno deve ter um papel ativo diante de uma situação, de certo modo comparado ao ato de produzir de um matemático.

Brousseau utiliza de Bachelard a idéia que um novo conhecimento se constrói a partir de conhecimentos antigos e, também, contra esses. Isto permite a dominação de saberes matemáticos, através da mobilização de conhecimentos como ferramentas. Deste modo "o aluno aprende adaptando-se a um meio que é um fator de contradições, de dificuldades, de desequilíbrios, um pouco como faz a sociedade humana. Este saber, fruto da adaptação do aluno, manifesta-se através de respostas novas, que são a prova da aprendizagem" (Brousseau, 1996a, p. 49).

\section{Situação didática}

O conjunto de relações estabelecidas explicitamente e/ou implicitamente entre um aluno ou grupo de alunos, um certo milieu (...) e um sistema educativo (o professor) para que esses alunos adquiram um saber constituído ou em vias de constituição (Brousseau, 1996a, p. 50).

O termo milieu" indica o meio a-didático, um sistema antagonista, sem intenção didática explícita e exterior ao aluno, que pode abranger, dentre outros, situações-problema, jogos, os conhecimentos dos colegas e professor. Brousseau (1996a) aponta que o milieu deve possibilitar a interação autônoma do aluno em relação às situações que interage e em relação ao professor. 
O Jogo Teorema de Pitágoras 1

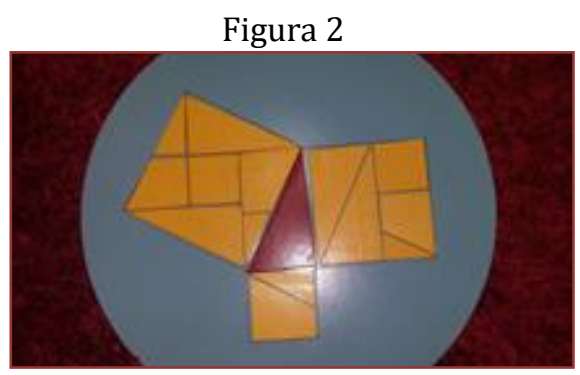

\section{Historiciando}

O Teorema de Pitágoras é considerado pelos vários estudiosos da matemática como um dos mais importantes da história. Vários resultados importantes em geometria teórica, bem como da solução de problemas práticos relacionados às medidas, foram descobertos através desse teorema. 0 fato é que o Teorema de Pitágoras é considerado um dos mais famosos e úteis da geometria elementar o que foi demonstrado por várias civilizações no decorrer da história. (Gaspar, 2003).

Representação Geométrica do Teorema de Pitágoras

"O quadrado da hipotenusa é igual à soma dos quadrados dos catetos".

Se a é a medida da hipotenusa e se b e c são as medidas dos catetos, o enunciado do Teorema equivale a afirmar que: $a^{2}=b^{2}+c^{2}$.

Figura 3

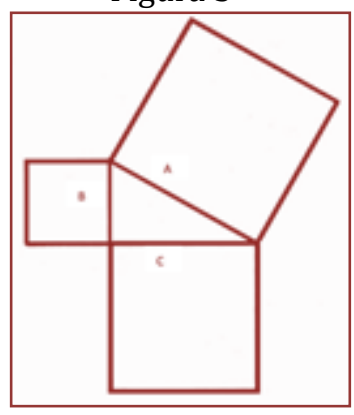

O interesse pelo jogo foi devido a este:

- Possibilitar evidenciar uma situação a-didática (jogo), que sem a utilização de qualquer atitude didática (intencional) pode provocar mudanças na estratégia do jogador;

- Possibilitar uma situação fundamental, definida como uma situação a-didática que é capaz de promover a aquisição do conhecimento;

Com a vivência do jogo o aluno é sabedor que o professor elaborou uma situação que ele tem condições e pode fazer, pelo menos em parte, pois esta é justificada pela lógica interna e pelos conhecimentos anteriores dele, não sendo necessário recorrer a qualquer intervenção didática do docente.

Etapas vivenciadas embasadas na Teoria das Situações Didáticas

1. Ação: Os participantes tomam decisões, colocando seus saberes em prática para resolver o problema. É quando surge um conhecimento não formulado matematicamente.

2. Formulação: Os participantes são levados a explicitar as estratégias usadas. Para isso, precisam formulálas verbalmente, transformando o conhecimento implícito em explícito. 0 participante retoma sua ação em outro nível e se apropria do conhecimento de maneira consciente. 
3. Validação: A estratégia é demonstrada para interlocutores. "O participante não só deve comunicar uma informação como também precisa afirmar que o que diz é verdadeiro dentro de um sistema determinado", diz Brousseau (1996). Cada equipe propõe o enunciado de sua estratégia para ganhar, contestando o do adversário.

4. Institucionalização: Aqui aparece o caráter matemático do que os participantes validaram. "É uma síntese do que foi construído durante o processo e tem um significado socialmente estabelecido". 0 professor tem um papel ativo, selecionando e organizando as situações que serão registradas.

Embasados nestas etapas sugerimos três momentos: 1. Vivenciando 0 jogo Teorema de Pitágoras em grupos. 2. Anotando as principais construções diante da exploração do jogo. 3. Discussão referentes as construções.

\section{RESULTADOS E DISCUSSÃO}

Durante a vivência do jogo na etapa da ação, momento de experimentar a composição das áreas tomando com base os catetos (figura 4), foi possível observar comentários como "está faltando peças", as "peças não se encaixam", "precisamos observar o tamanho dos lados".

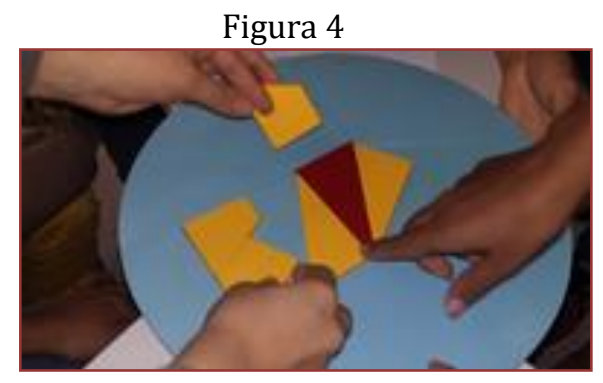

No transcorrer da vivência nas etapas da formulação e validação foi solicitado como mostrar o teorema com o auxílio da malha quadriculada (figura 5). Nesse momento foi possível observar o aparecimento de um nível de dificuldade quando questionaram "Podemos usar a régua para a composição das figuras?".

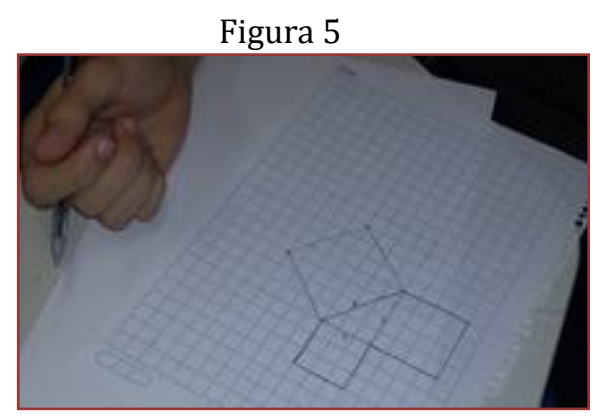

Posteriormente a todas as discussões que foram traçadas no transcorrer da vivência da oficina, na etapa da Institucionalização foi sistematizado aspectos referentes à Demonstração do Teorema de Pitágoras através de quadriculados, verificando num triângulo retângulo de catetos 3 e 4 e consequentemente a hipotenusa medindo 5. Podemos citar que esta é uma demonstração clássica apresentada em livros didáticos. 


\section{Figura 6}

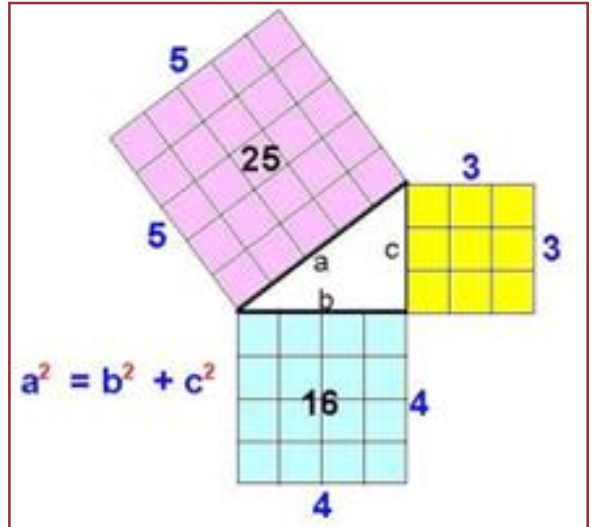

Posteriormente a discussão traçada referente a esta demonstração, foi expandida para a situação de outras áreas conforme explicitada na figura 5, aprofundando as discussões.

Figura 7

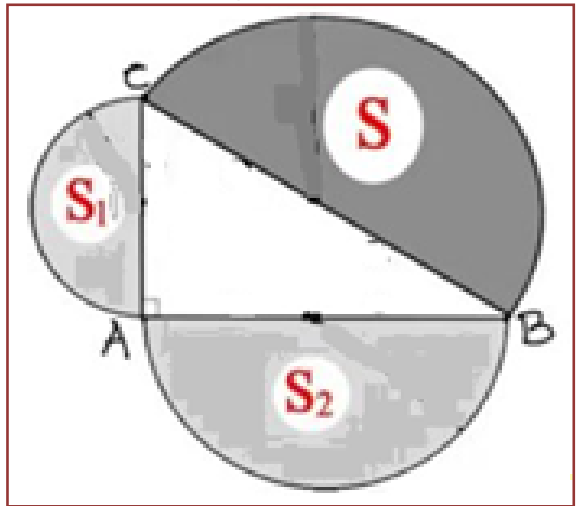

Neste momento, ficou clara a possibilidade de traçar relações da demonstração com polígonos variados. Vale ressaltar um comentário explicitado por um participante da oficina no término desta oficina: na educação básica só vemos a ida do Teorema com os números e não à volta.

\section{CONCLUSÃO}

De acordo com a proposta inicial com esta atividade procuramos promover contribuições para a futura prática pedagógica do professor de matemática, possibilitando a compreensão da natureza do trabalho didático, bem como as transformações porque passam os conteúdos ensinados na escola e quais os recursos que permitem a Transposição Didática destes.

\section{REFERÊNCIAS}

[1] Brousseau, G. Introdução ao estudo da teoria das situações didáticas: conteúdos e métodos de ensino. São Paulo: Ática, 2008.

[2] Brousseau, G.Didáctica das Matemáticas /Brun, J...[et al]; Direção: Jean Brun. Trad: Maria José Figueredo, Lisboa: Instituto Piaget. .1996.

[3] Chevallard, Y. La Transposición Didáctica -Del saber sabido al saber enseñado. Argentina: Aique. 1991.

[4] Fainguelernt, E.K. O Ensino de Geometria no $1^{\circ}$ e $2^{\circ}$ graus. Revista da Sociedade Brasileira de Educação Matemática. São Paulo, ano III, no 4, p.45-53, 1osemestre 1995.

[5] Gil, A. C. Como elaborar projetos de pesquisa. 4. ed. São Paulo: Atlas, 2008. 
[6] Pais, L. C. Tendências em Educação Matemática - Didática da Matemática - Uma análise da influencia francesa. Belo Horizonte: Autêntica. 2001.

[7] Parâmetros Para a Educação Básica de Pernambuco. Disponível em: http://www.educacao.pe.gov.br/ Acesso em: 03de set. 2017. 


\section{Capítulo 4}

Processo de ensino e aprendizagem em disciplina de Geometria Espacial: Uma experiência com produção de texto e material concreto

\section{Valter Locci}

\section{Emília de Mendonça Rosa Marques}

Resumo: Este capítulo traz o relato dos autores sobre a experiência obtida no desenvolvimento da disciplina de Geometria Espacial em turmas de formação inicial de professores de Matemática, num espaço de 6 anos. Apresenta-se resultados de formação através da proposta de que os graduandos, estudantes do segundo ano da licenciatura referida, ao final da disciplina, apresentassem oralmente e em grupo, um trabalho contendo: material escrito e material concreto sobre sólidos produzidos com canudos e fitilho. Nos textos deveriam utilizar um software geométrico para a confecção das figuras. A metodologia proposta em todas as turmas foi de grupos colaborativos. Para as turmas nos quatro primeiros anos foi proposto a construção dos poliedros de Platão com propriedades comuns fixadas e nos dois últimos anos trabalhou-se com poliedros estrelados e semirregulares. 0 trabalho em grupo se mostrou muito adequado aos objetivos da disciplina e o material concreto apresentado pelos grupos está disponibilizado no Laboratório Didático de Matemática do referido curso.

Palavras-Chave: Geometria Espacial, Material Concreto, Grupos Colaborativos. 


\section{INTRODUÇÃO}

O curso de Licenciatura em Matemática da Faculdade de Ciências da UNESP/Bauru, está neste ano de 2019 comemorando 50 anos de criação. Nesse período, passou por várias modificações de enfoque, projeto pedagógico e grade curricular.

Na reestruturação aprovada em setembro de 2005 para implantação no ano seguinte, foi introduzida a disciplina Geometria Espacial, a qual foi oferecida pela primeira vez em 2007, para os estudantes desse currículo cursando o $2^{\circ}$ ano. Nessa proposta o conteúdo matemático específico se constituiu dos seguintes tópicos: prismas, paralelepípedos, pirâmides, cilindros, cones, troncos de pirâmide e de cones, esfera e suas partes, e inscrição e circunscrição de sólidos. Dada sua importância na formação inicial de professores de Matemática, a disciplina permanece na grade curricular vigente, agora acrescida dos tópicos: Axiomas e Propriedades; Geometria de posição - Paralelismo e Perpendicularidade; Aplicações Projeções, Distâncias e Ângulos; Diedros, triedros e poliedros convexos e de práticas como componentes curriculares (PCC). A disciplina objetiva a construção correta dos conceitos e propriedades de Geometria Métrica Espacial, bem como a criação, e ou adaptação, de estratégias e materiais didáticos, que potencializem seu ensino nos níveis Fundamental e Médio, incluindo o trabalho com as novas Tecnologia de Informação e Comunicação (NTIC).

A metodologia proposta envolve: a) Utilização de sólidos geométricos concretos no desenvolvimento dos conceitos e propriedades, dando enfoque na instrumentalização para o ensino; b) Resolução de exercícios; c) Discussão da apresentação desse conteúdo nos livros-textos usualmente propostos na Educação Básica; d) Discussão de artigos científicos envolvendo conceitos de Geometria Espacial da Revista do Professor de Matemática; e) Trabalhos desenvolvidos em grupos.

Neste contexto, nos anos de 2007 a 2012, o desenvolvimento de uma proposta de trabalho com as turmas da disciplina de Geometria Espacial propiciou a experiência aqui relatada.

\section{METODOLOGIA}

No trabalho realizado em sala de aula, foram utilizadas ferramentas didáticas como: aulas expositivas, proposição de problemas (DOLCE; POMPE0,1988) e (CARVALHO, 1999), utilização de software gráfico geométrico para construção de figuras e manipulação de material concreto (canudinhos e fitilhos). Paralelamente a esse trabalho, no início de cada semestre, propôs-se para cada uma das turmas, uma tarefa desafiadora a ser desenvolvida em grupos com o objetivo de trabalhar algum tema da Geometria Espacial numa abordagem envolvendo práticas teóricas, concretas, virtuais e expositivas, explicitadas nas seguintes etapas exigidas: $1^{\mathfrak{a}}$ ) entrega de um trabalho escrito contendo definições e desenvolvimento algébrico; $2^{\underline{a}}$ ) uso de algum software gráfico para construção das figuras utilizadas no trabalho escrito; $3^{\underline{a}}$ ) entrega de sólidos concretos construídos com canudos e $4^{\mathfrak{a}}$ ) apresentação oral em sala de aula do trabalho realizado pelos grupos.

Cabe destacar que, inserido aos conteúdos específicos da disciplina Geometria Espacial, estava a aprendizagem e utilização de um software gráfico, por exemplo Wingeom (PARRIS, 2012), para a construção de figuras planas e espaciais. Esse software foi trabalhado inicialmente através de aulas práticas no Laboratório de Ensino de Informática, utilizando-se objetos de aprendizagem desenvolvidos para esse fim, cujo conteúdo é o de Geometria Plana. Desta forma os estudantes aprendem o software e revisam conceitos imprescindíveis para a construção dos conceitos propostos em Geometria Espacial. Atualmente trabalha-se também com o software de geometria dinâmica GeoGebra (GEOGEBRA, 2019), na versão mais atualizada que inclui um pacote de visualização 3D.

Na construção dos sólidos com materiais concretos, considerando-se as variáveis preço, facilidade de manipulação, acabamento, armazenamento e durabilidade, deu-se preferência aos canudos e fitilhos, conforme (KALEFF; REI, 1995). Artigos da Revista do Professor de Matemática, por exemplo (PEDONE, 1989) e (SARAIVA, 2002), que tratam de temas relativos aos conteúdos específicos da Geometria Espacial, foram indicados como referência para o trabalho nos grupos, visando o desenvolvimento do raciocínio matemático a ser utilizado na abordagem dos temas propostos para cada grupo. 


\section{RESULTADOS E DISCUSSÃO}

A primeira turma, 2007, foi constituída de 26 alunos distribuídos em quatro grupos. A tarefa desafiadora proposta foi a de construir poliedros de Platão (Tetraedro, Hexaedro, Octaedro, Dodecaedro e Icosaedro) com canudinhos inteiros (arestas) e fitilhos considerando em cada grupo uma característica específica adicional, descrita a seguir: G1 - sólidos com a mesma área lateral (total); G2 - sólidos com o mesmo volume; G3 - sólidos inscritíveis em uma esfera; G4 - sólidos circunscritíveis a uma esfera.

No trabalho escrito os grupos deveriam apresentar todos os cálculos realizados para obtenção dos dados para a confecção adequada dos sólidos, os quais foram avaliados, juntamente com o material concreto produzido em cada grupo, segundo critérios explicitados verbalmente pelo docente. Os trabalhos escritos apresentaram os cálculos corretos, porém de forma sucinta. Dois trabalhos foram digitados e dois manuscritos. 0 material concreto entregue apresentou bastante qualidade e suas dimensões se mostraram adequadas para auxiliar os grupos, em sala de aula, no desenvolvimento do raciocínio para deduzir as fórmulas necessárias. Entretanto, como os esqueletos (arestas apenas) dos sólidos ficaram "grandes", conforme mostra a figura 1, observou-se a dificuldade de armazenamento dos mesmos, ficando assim evidenciada a necessidade de redução das dimensões na próxima proposta. Visando um envolvimento efetivo de todos os alunos nas discussões em sala de aula acrescentou-se a apresentação oral dos trabalhos, para as turmas seguintes.

Em 2008, a turma também foi distribuída em quatro grupos e a tarefa desafiadora foi a mesma, exceto pelo tamanho dos esqueletos dos poliedros de Platão, tendo nesta edição, a maior aresta (canudinho) comprimento igual a $10 \mathrm{~cm}$.

Figura 1. Material concreto entregue por um dos grupos da turma de 2007.

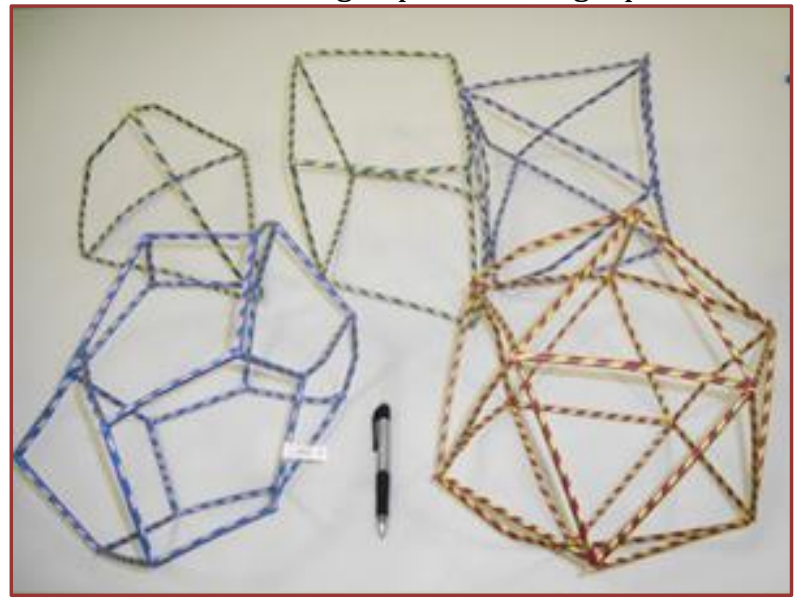

Figura 2. Material concreto entregue por um dos grupos da turma de 2008.

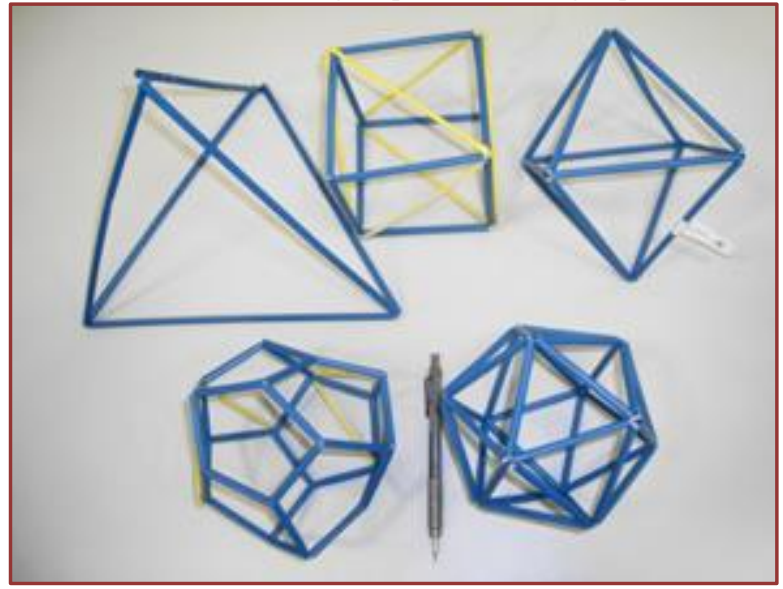


Em 2009, a turma foi dividida em seis grupos, sendo que quatro destes construíram "esqueletos" dos poliedros de Platão com canudinhos e fitilho (ou cordão), tendo a maior aresta comprimento igual a $16 \mathrm{~cm}$ ou $20 \mathrm{~cm}$. Nesta edição, o grupo que construiu os sólidos com a mesma área precisou ainda se preocupar em inscrever em cada um deles, o seu dual (Fig.3). Os outros dois grupos construíram cinco pirâmides regulares equiláteras (inscritas em cones eqüiláteros), tendo o polígono da base $n$ lados ( $n=3,4,5,6$ e 8), conforme mostra a Figura 4, sendo que tais pirâmides devem ser inscritas ou circunscritas numa mesma esfera.

Figura 3. Sólidos com os respectivos duais inscritos - Turma de 2009.

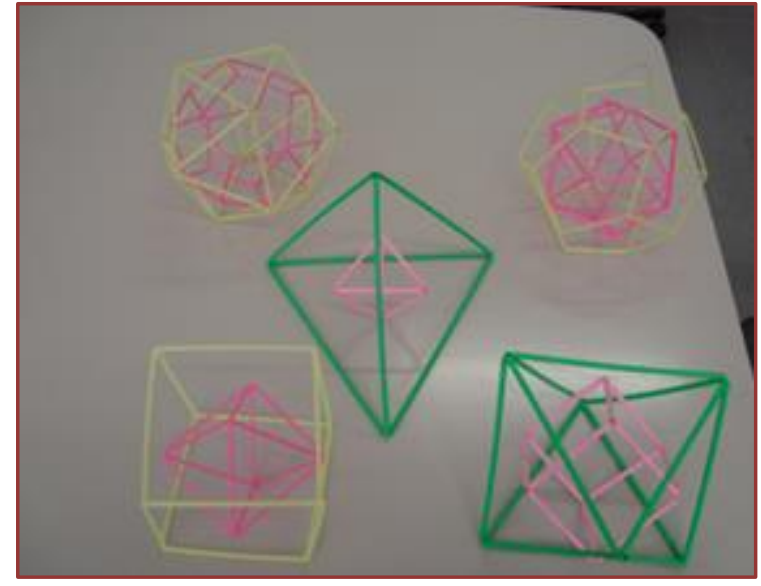

Figura 4. Pirâmides cujos polígonos da base possuem de 3 a 6 e 8 lados - Turma de 2009.

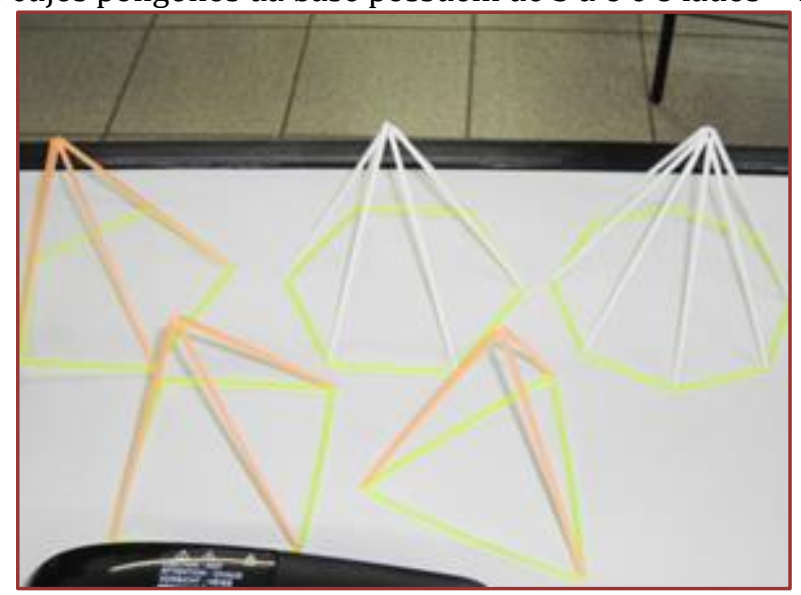

Em 2010, constituiu-se cinco grupos de alunos com a mesma tarefa de construir os "esqueletos" dos poliedros de Platão, acrescido da exigência de construir esferas interiores aos polígonos, tangentes as suas faces e arestas (Fig.5). Introduziu-se também, uma quinta etapa no trabalho, solicitando o planejamento, redação e proposição de um tema de Geometria Espacial que fosse adequado para propostas desafiadoras, para as próximas turmas da disciplina. A proposição desta nova etapa proporcionou maior participação dos alunos na discussão dos temas, visão global dos conteúdos da disciplina e diversificação de temas.

$\mathrm{Na}$ avaliação dos trabalhos resultado das tarefas de cada grupo, foram considerados três itens: a) Trabalho Escrito: capa, formatação, desenvolvimento do tema, cálculos, desenhos, resultados, referências; b) Construção dos Sólidos: acabamento, uniformização, montagem, medidas; c) Apresentação do Trabalho: recursos utilizados, animação, domínio do tema, clareza, precisão, divisão das tarefas, participação dos membros do grupo. 
No ano de 2011, com os alunos distribuídos em seis grupos, foi proposto um o novo tema, proveniente das propostas da turma anterior. Este era inovador, mais desafiador e de confecção muito mais trabalhosa, de modo que cada grupo passou a trabalhar com apenas dois poliedros. 0 tema da tarefa foi poliedros de Kleper-Poisont e os grupos assim distribuídos: G1 - Grande Dodecaedro Estrelado e Pequeno Dodecaedro Estrelado com mesma área; G2 - Grande Dodecaedro Estrelado e Pequeno Dodecaedro Estrelado com mesma esfera circunscrita; G3 - Grande Dodecaedro Estrelado e Pequeno Dodecaedro Estrelado com mesmo volume; G4 - Grande Dodecaedro e Grande Icosaedro com mesma área.G5 - Grande Dodecaedro e Grande Icosaedro com mesma esfera circunscrita; G6 - Grande Dodecaedro e Grande Icosaedro com mesmo volume. 0 resultado do trabalho dos estudantes dessa turma está apresentado na Figura 6.

Com a inovação do tema, devido à maior complexidade do assunto e ao maior número de alunos e grupos, as apresentações foram realizadas em dois dias.

Figura 5. Sólidos com as respectivas esferas inscritas - Turma de 2010.

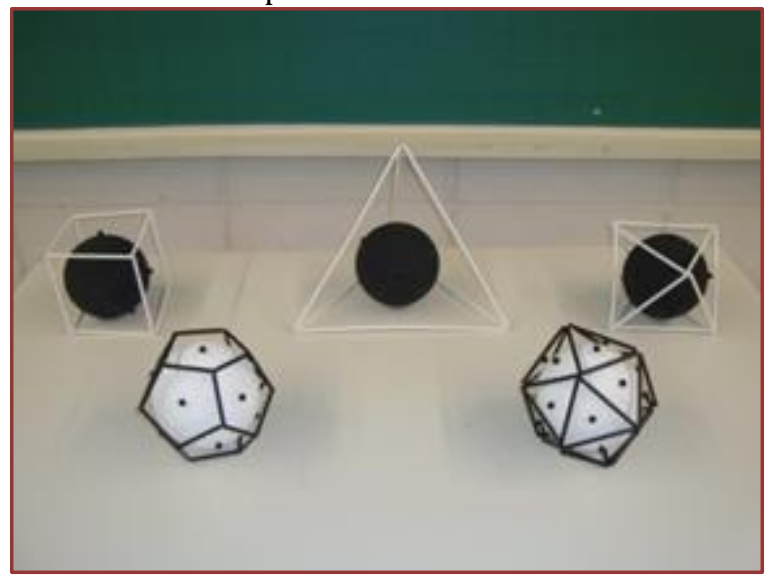

Figura 6. Sólidos estrelados - Turma de 2011.

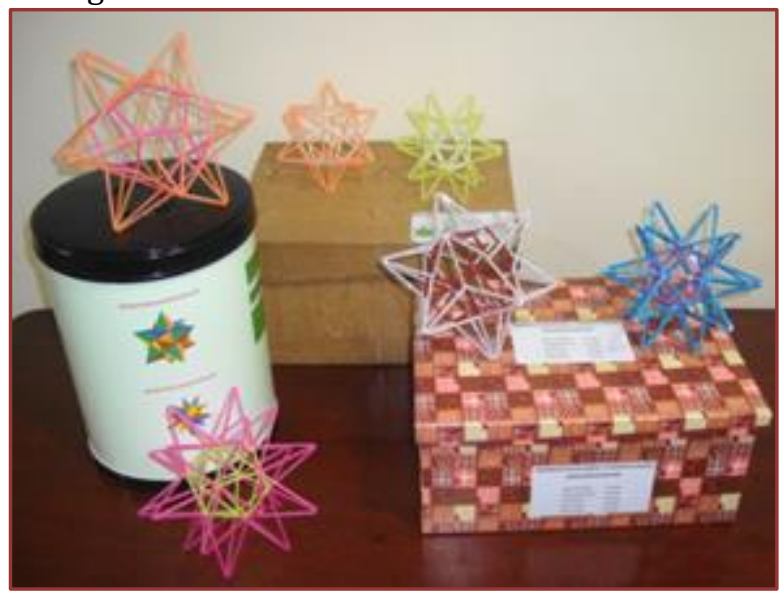

Em 2012, constituíram-se cinco grupos e o tema proposto foi poliedros Arquimedianos (ou semirregulares) de acordo com a seguinte distribuição: G1-Tetraedro Truncado, Cuboctaedro, Cubo Truncado e Octaedro Truncado, com mesmo volume; G2 - Rombicuboctaedro e Cuboctaedro Truncado, com mesmo volume; G3 - Cosidodecaedro, Dodecaedro Truncado e Icosaedro Truncado, com mesma área; G4 - Rombicosidodecaedro e Icosidodecaedro Truncado, com mesma área; G5 - Cubo Snub e Icosidodecaedro Snub, com mesma área 
Figura 7. a - d. Poliedros Arquimedianos - Turma de 2012.
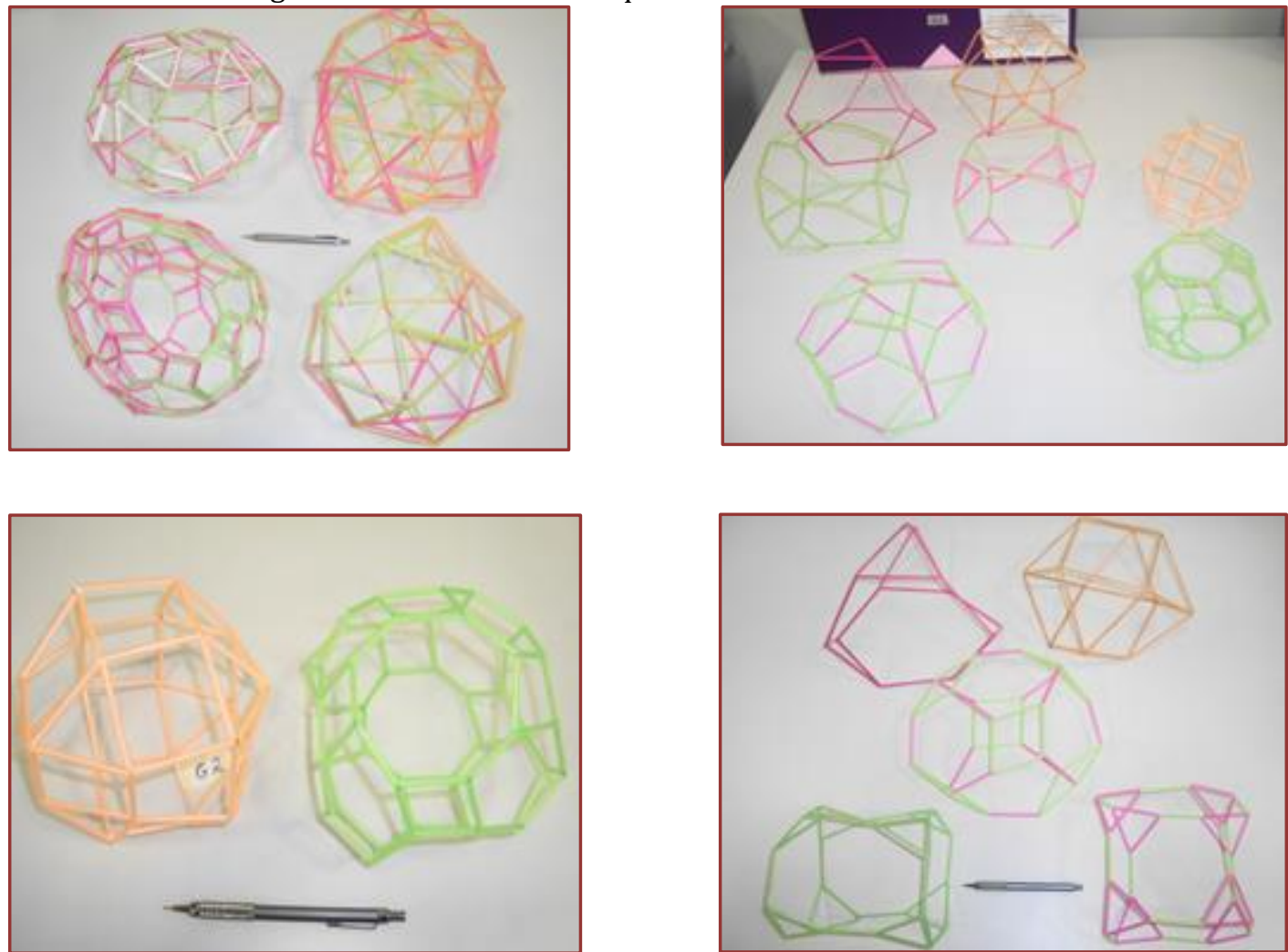

As apresentações desta turma também foram realizadas em dois dias e, à semelhança da turma anterior, mesmo considerando a maior dificuldade de confecção dos sólidos propostos, os trabalhos ficaram muito bem montados e acabados.

\section{CONSIDERAÇÕES FINAIS}

0 trabalho em grupo se mostrou muito adequado às tarefas propostas, visto que a participação muito ativa dos alunos da disciplina, tanto em sala de aula, quanto nas reuniões para desenvolvimento dos trabalhos, se evidenciou fortemente. Os alunos aprenderam efetivamente a utilizar o software gráfico para construção de figuras geométricas e treinaram o desenvolvimento de raciocínio colaborativo em grupo, utilizando o material concreto na dedução algébrica dos resultados e vice-versa. Aprenderam, na prática, a produzir um texto científico e didático, planejaram e construíram material didático concreto de apoio ao texto para uso no Laboratório Didático de Matemática do curso.

Ressalta-se que alguns alunos tiveram a oportunidade de experienciar uma apresentação oral de trabalho, pela primeira vez neste curso de formação de professores.

Esta experiência didática foi publicada inicialmente em (LOCCI; MARQUES, 2013).

Observamos que Radin (2018) e Nogueira (2014), em suas dissertações de mestrado, corroboram com nossa experiência didática, desenvolvendo estratégias e novas abordagens para o ensino de Geometria Espacial através do estudo dos Poliedros de Platão.

\section{REFERÊNCIAS}

[1] Carvalho, Paulo Cezar Pinto. Introdução à geometria espacial. Coleção do Professor de Matemática, Rio de Janeiro: SBM, 1999.

[2] Dolce, Osvaldo; Pompeo, José Nicolau. Geometria espacial, posição e métrica. 5.ed. Coleção Fundamentos de Matemática Elementar, V. 10. São Paulo: Atual, 1998.

[3] Geogebra. Site Oficial. Disponível em <https://www.geogebra.org/>. Acesso em: 29.10.2019. 
[4] Kaleff, Ana Maria; Rei, Dulce Monteiro. Varetas, canudos, arestas e ... sólidos geométricos. Revista do Professor de Matemática. n.28, p.29-36, 1995.

[5] Locci, Valter; Marques, Emília De Mendonça Rosa. Ensino de Geometria Espacial na Licenciatura em Matemática: Uma Proposta de Trabalho com Grupos Colaborativos. CQD - Revista Eletrônica Paulista de Matemática, v. 2, p.1-6, 2013.

[6] Nogueira, Simone Paes Gonçalves. Poliedros de Platão como estratégia no ensino da Geometria Espacial. UFABC. 2014. 123 p. Dissertação (Mestrado Profissional em Matemática em Rede Nacional - PROFMAT) Universidade Federal do ABC. Santo André, 2014.

[7] Parris, Rick. Wingeom (1.01M) for Windows 95/98/ME/2K/XP/Vista/7. 2012. Disponível em: <http://math.exeter.edu/rparris/wingeom.html>. Acesso em: 08.04.2015.

[8] Pedone, Neuma Maria Duarte. Poliedros de Platão. Revista do Professor de Matemática, n.15, p.42-45, 1989.

[9] Radin, Leandro Duarte. Abordagens diversificadas para o ensino dos poliedros de Platão. UFSM. 2018.97 p. Dissertação (Mestrado Profissional em Matemática em Rede Nacional - PROFMAT) - Universidade Federal de Santa Maria. Santa Maria, 2018.

[10] Saraiva, José Cloves Verde. 0 poliedro regular de maior volume. Revista do Professor de Matemática, n. 49, p.15-20, 2002. 


\section{Capítulo 5}

Matemática e jujubas: Uma proposta lúdica do ensino de figuras e sólidos geométricos nos anos iniciais

\section{Hellen Cris de Almeida Rodrigues \\ Emanuella Silveira Vasconcelos \\ Marnilde Silva de Farias \\ João Luiz da Costa Barros}

Resumo: A matemática está em tudo. É comum exercitar durante o dia-a-dia os conhecimentos matemáticos apreendidos ao longo da vida escolar. Assim, o objetivo da intervenção descrita foi ampliar conceitos matemáticos trabalhados em sala de aula e despertar o interesse dos alunos ao conteúdo estudado de forma lúdica. 0 presente relato mostra os resultados e reflexões dos trabalhos realizados com alunos do $2^{\circ}$ ano do Fundamental através de uma proposta de atividades com jujubas a fim de apreender noções de geometria, ou seja, sólidos geométricos, com material construído pelos discentes objetivando ampliar os conceitos matemáticos explorados durante as aulas de forma dinâmica. A atividade de ensino foi desenvolvida no Colégio de Aplicação na Universidade Federal de Roraima CAp/UFRR, no município de Boa Vista no estado de Roraima no ano de 2018.

Palavras-chave: Educação Matemática, Sólidos Geométricos, Ludicidade. 


\section{INTRODUÇÃO}

A matemática está em tudo. 0 ensino desta disciplina ainda se caracteriza como um grande desafio para professores das séries inicias. Diante disso, a ludicidade se configura como uma possibilidade para auxiliar o trabalho docente. Este tipo de metodologia possibilita ao discente a superação das dificuldades existentes de forma prazerosa. Muitas são as indagações recorrentes sobre a utilização do lúdico nas aulas de matemática, tais como: De que maneira as estratégias de ensino podem ser utilizadas para auxiliar na superação das dificuldades na matemática? Como tornar a aula de matemática prazerosas? Qual a importância de trabalhar o lúdico na sala de aula? Buscamos por meio destas reflexões responder estas questões por meio de uma experiência que se mostrou exitosa.

Este trabalho descreve a metodologia de uma proposta lúdica referente ao conteúdo de noções de geometria, abordando conceitos voltados para as séries iniciais, mais precisamente ao 2 o ano do Ensino Fundamental e aponta reflexões a respeito do trabalho com jogos nas aulas de matemática nas séries iniciais. 0 objetivo do presente trabalho foi consolidar a técnica dos sólidos geométricos por meio da técnica de jujubas (balas de goma) numa a perspectiva lúdica a fim de garantir a apreensão dos conceitos mediados ao longo das aulas de matemática. 0 projeto de ensino foi desenvolvido no Colégio de Aplicação na Universidade Federal de Roraima CAp/UFRR, no município de Boa Vista no estado de Roraima. 0 público-alvo foram 24 alunos com a faixa etária entre 7 e 8 anos.

Dessa forma, o presente relato divide-se em dois momentos. Inicialmente o detalhamento da metodologia em que este estudo foi executado e posteriormente explicita-se os resultados da experiência. Buscamos ainda dialogar com as ideias dos autores propostos referentes a temática. Os resultados do presente estudo apontam para a mudança conceitual e atitudinal dos envolvidos no estudo além de se configurar como experiência formadora para a prática docente.

\section{METODOLOGIA}

A proposta de trabalho descrito foi desenvolvido junto a disciplina de Matemática no Colégio de Aplicação - CAp/UFRR, localizado no município de Boa Vista - RR. 0 público-alvo foram 24 alunos do $2^{\circ}$ ano do Fundamental I com faixa etária entre 7 e 8 anos de idade. A proposta de trabalho com jujubas justifica-se por entender que no processo de aprendizagem a ludicidades possibilita a apreensão de conceitos de forma significativa. Além disso, desenvolve outras habilidades, tais como: atenção e concentração do aluno ao mesmo tempo que explora a parceria, valoriza os saberes matemáticos entre outras habilidades.

A proposta de trabalho com do referido conteúdo objetivou dentre outras coisas, possibilitar que os discentes fossem capazes de classificar os diferentes sólidos, estabelecer relação com os objetos do dia-adia, além de construir os sólidos geométricos de maneira independente. A problemática surge a partir da identificação das dificuldades dos alunos em assimilar os conhecimentos abordados. Dessa forma, foi criada uma sequência didática com três momentos/atividades específicas com atividades que facilitariam o processo de ensino e aprendizagem dos alunos.

O primeiro momento consistiu no diálogo das vivências do alunado, ou seja, o resgate do conhecimento prévio que os mesmo possuíam em relação ao tema trabalhado. É preciso destacar que identificou-se uma conhecimento consolidado em relação as figuras geométricas, diferente dos sólidos. Aproveitando o momento de troca de experiências, foi apresentada diferentes embalagens e objetos que são comuns no cotidiano das crianças a fim de levantar de forma coletiva características e ainda construir hipóteses a partir de direcionamentos encaminhados pela professora.

As embalagens e objetos apresentados a foram: caixas de creme dental, rolo de papel higiênico, funil, dados e bola. Depois disso, a turma foi dividida em pequenos grupos responsável por um tipo de sólido. Os grupos ficaram responsáveis em pesquisar informações referente a cada objeto buscando responder as seguintes questões: esse objeto pode rolar? Com que sólidos geométricos se parecem? Por que são chamados de tridimensionais? O que são arestas, vértices e faces? A pesquisa foi realizada no livro didático e em material disponibilizado pela professora aos grupos. Após essa atividade, as repostas foram apresentadas para todo o grupo e sintetizadas em forma de texto coletivo no quadro e anotadas pelas crianças nos cadernos. Além disso, foi disponibilizado do data show imagens informativas que auxiliariam as crianças na execução das atividades. 
Imagem 02: imagem da internet

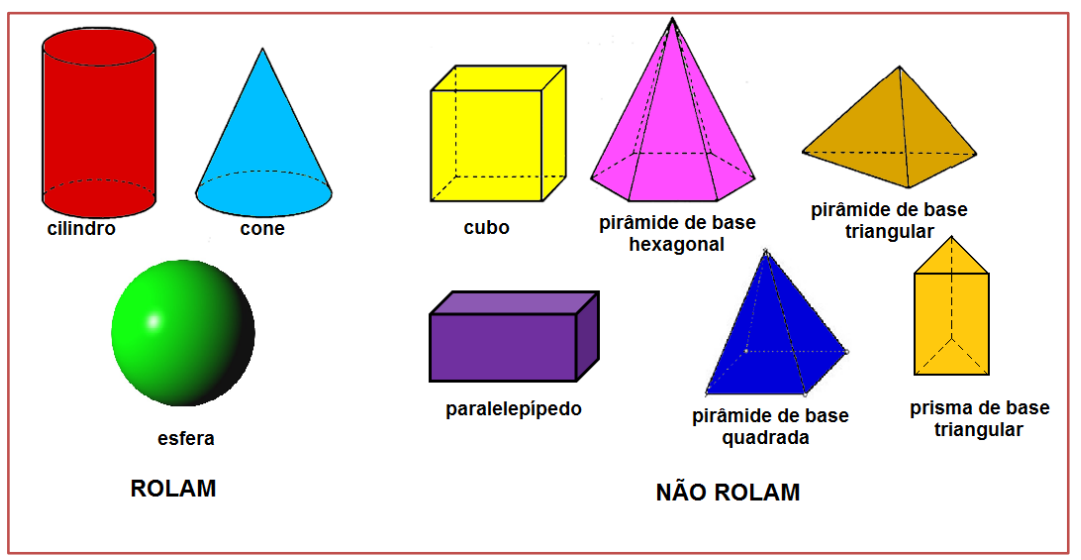

O segundo momento consistiu na construção dos sólidos geométricos. Depois de ser dividida em pequenos grupos, foram distribuídas imagens planificadas de sólidos geométricos. Antes disso, os grupos organizaram informações em tabelas anotando dados importantes, tais como: números de faces, vértices e de figuras geométricas (retângulos, quadrados, círculos e triângulos) encontradas. Os objetos e embalagens bem como as informações anotadas no primeiro momento, serviram de subsidio para a referida atividade. Nesse sentido, foram retomados junto aos alunos as características presentes nos sólidos bem como os seus nomes.

0 terceiro momento foi o de construção dos sólidos geométricos com jujubas e palitos de dentes. Foi pedido antecipadamente que cada aluno trouxesse para a aula de matemática o material necessário para execução da atividade proposta. Durante as aulas que antecederam as atividades foram trabalhados conceitos matemáticos dos conteúdos estabelecidos, a fim de garantir que os discentes relacionassem os conceitos construídos com o concreto.

O trabalho foi realizado de modo coletivo, mas cada aluno possuía jujubas e palitos para construir seu próprio sólido. A atividade foi direcionada pela professora e contou com o apoio da cuidadora de aluno. Após a construção dos sólidos houve uma pequena amostra dos trabalhos realizados para todos os alunos que fazem parte da turma. Os sólidos construídos foram: paralelepípedo, cubo, pirâmide triangular, pirâmide quadrangular e prisma. Após a construção de cada sólido geométrico, foi realizado diálogos com os alunos a fim de resgatar os conceitos trabalhados durantes a execução da sequência didática.

\section{DESENVOLVIMENTO}

Os Parâmetros Curriculares Nacionais de Matemática (BRASIL, 1998), abordam a relação entre as possibilidades que o jogo e o ensino de matemática trazem a aprendizagem das crianças nos anos iniciais de ensino. Segundo o documento, por meio do jogo é possível a criança ter contato com problemas semelhantes os da vida cotidiana, e neste momento ela pode, de forma alegre e divertida elaborar estratégias que visem solucionar os problemas apresentados. Ou seja, é ao jogar, que a criança pode experimentar hipóteses, criar estratégias e simular situações em que a vida real ainda não lhe permite, isso se configura como atividades lúdicas.

Nas aulas com jogos há uma maior interação entre os alunos e a professora e entre os próprios alunos, nas dinâmicas em duplas e grupos, uns ajudam os outros e essa relação de coleguismo contribui muito para uma aprendizagem interativa e divertida, assim as aulas se tornaram mais agradáveis e proporcionam às crianças a oportunidade de criar e imaginar novas formas de aprender, sem ter que sair do conteúdo da disciplina, assim como puderam aprender mais efetivamente os conteúdos, pois houve maior articulação entre teoria e prática.

0 jogo quando usado como recurso pedagógico, mostrasse eficaz para o processo de ensino-aprendizagem no contexto da matemática. Na compreensão de Vigotsky (1998), o brinquedo (situação imaginária) propicia que a criança haja cognitivamente, explora a curiosidade, linguagem, emoção e criatividade. Dessa forma, acreditamos que por meio dos jogos matemáticos elaborados possibilitou o desenvolvimento dos alunos do $2^{\underline{o}}$ ano e fez com que esses gostassem de apreender esta disciplina, mudando assim significativamente a rotina da classe e o interesse dos alunos envolvidos. 
Acreditamos também, que os jogos podem contemplar os aspectos destacados por Cabral (2006) como importantes ao uso do jogo do contexto escolar. São eles: o caráter lúdico, já que teve o intuito de educar ao mesmo tempo em que promover a socialização entre os participantes; o desenvolvimento das técnicas intelectuais, uma vez que diferentes conteúdos e habilidades matemáticas foram exploradas; e por último, a formação de relações sociais, sendo possível observar a maior interação entre os alunos e a necessidade de compreender regras de convívio para que o momento do jogo ocorresse a contento.

Nesse sentido, compreendemos que a presente proposta não teve fim em si mesmo, mas possibilitou significativos avanços em aspectos, motores, emocionais, intelectuais e sociais, e que portanto também cumpre com as funções sociais da escola que é de educar a criança na integralidade.

\section{RESULTADOS E DISCUSSÃO}

Estratégias lúdicas no ensino da matemática nas séries iniciais possibilitam ao aluno o desenvolvimento de habilidades significativas e importantes no processo de ensino e aprendizagem, tais como: atenção, concentração, aquisição do raciocínio lógico, da resolução de situações-problema, criatividade, dentre outras coisas mais. $\mathrm{O}$ envolvimento dos alunos foi perceptível e foi comum ouvi-los dizer que aquela estava sendo uma aula divertida.

Utilizar a ludicidade como ferramenta de ensino é fazer com que os alunos tenham uma aprendizagem diferenciada, com estratégias aliada à construção do conhecimento, devendo planejar cuidadosamente sua execução. Daí a importância do docente, preparar suas aulas utilizando os jogos, as brincadeiras e outras atividades lúdicas como ferramentas que estimulem a aprendizagem e potencializem as possibilidades de aprender os conteúdos de maneira prazerosa e articulada com a realidade em que os alunos vivem.

Entende-se que a motivação dos discentes no processo de aquisição de conhecimentos facilita a apreensão dos conteúdos mediados. Nessa perspectiva, o lúdico se configura como um importante instrumento que possibilita a construção e desconstrução de novos saberes. Nesse sentido, a por meio atividades lúdicas o alunos constrói seu próprio raciocínio e estratégia para a solução de situações problema. Para Grando,

[...] É fundamental inserir as crianças em atividades que permitam um caminho que vai da imaginação à abstração, através de processos de levantamento de hipóteses e testagem de conjecturas, reflexão, análise, síntese e criação, pela criança, de estratégias diversificadas de resolução dos problemas em jogo. (GRANDO, 2000, p. 20).

É importante o professor utilizar metodologias adequadas para cada jogo e atividade, portanto, é necessário pensar sobre: a melhor maneira de organizar os grupos, a quantidade de participantes e a organização de grupos de alunos com diferentes níveis de aprendizagens e dificuldades, de modo a possibilitar maior interação e possibilidades de aprendizagens. A utilização dos jogos como ferramenta de ensino alcançou resultados positivos no que se refere à aprendizagem, no desenvolvimento de aspectos da convivência social e no envolvimento dos alunos nas atividades propostas. Kishimoto (1992, p. 16) diz que "[...] através da atividade lúdica a criança forma conceitos, seleciona ideias e estabelece relações lógicas".

Ao apresentar embalagens e objetos do cotidiano a troca de saberes referente a sólidos geométricos além de divertida ficou bastante ampla. Os alunos identificaram ainda objetos da sala de aula garantindo com que o objetivo da atividade fosse alcançado. Além disso, possibilitar informações a respeito do conteúdo estudado, garante uma ampliação de saberes e ampla de mundo, haja vista que a matemática nos dias de hoje caracterizavam como simples momentos de transmissão de saberes, implicando em visões simplistas da realidade.

A construção de sólidos geométricos a partir de imagens planificadas de sólidos geométricos, atividade da sequência didática, oportunizou o reforço do conteúdo abordado. Essa proposta objetivou tratar a respeito das figuras e sólidos geométricos de modo que os discentes pudessem visualizar como os dois se relacionam a partir da resolução de hipóteses criadas por eles mesmos.

A atividade com palitos de dentes e jujubas/gomas se caracterizou como significativa no processo de apreensão dos conteúdos mediados. 0 trabalho com sequências didáticas no ensino da matemática para as séries iniciais na proposta descrita se configurou como importante instrumento didático para a desenrolar das atividades. Essa forma de mediação possibilita um maior envolvimento dos alunos e valoriza a continuidade das atividades. Nesse sentido, é importante ressaltar que a ludicidade está relacionada com os jogos nas aulas de matemática e estes por sua vez, possibilitam uma aprendizagem significativa. 
As discussões (análises) geradas a partir dos resultados deverão ser criativas, inovadoras e éticas, de maneira a corroborar com as instruções de pesquisa científicas do país. Levando em consideração a referencia a autores e teorias, bem como referenciando os resultados encontrados.

\section{CONSIDERAÇÕES FINAIS}

O ensino de matemática deve ser prazeroso, e não um cumprimento curricular obrigatório. Dessa forma, é necessário romper com o tradicional, principalmente se alunos não conseguem aplicar os conhecimentos ensinados na escola em sua vida cotidiana. Acreditamos que ao incorporarmos as propostas de atividades lúdicas e jogos as aulas de maneira consciente e principalmente compromissada, poderemos colher excelentes frutos no que diz respeito ao desenvolvimento dos alunos.

Por meio do jogo é possível aproximar a criança da elaboração de estratégias de resolução de problemas, que não vinculam-se apenas as questões matemáticas, mas estão presentes cotidianamente em nossas vidas. Para isso, é necessário que o professor compreenda a sua importância na relação mediadora entre objeto do conhecimento e aluno, ao questionar sobre as jogadas, as estratégias e as diferentes interpretações e/ou soluções dos conceitos abordados no jogo. Caso essa mediação não ocorro, a atividade corre o sério risco de não promover aprendizagem e não alcançar os objetivos previstos.

É papel da escola promover situações de aprendizagem significativa, que possibilitem a formação de cidadãos conscientes, que possam aplicar conscientemente em sua vida cotidiana os conhecimentos adquiridos na escola. Acreditamos assim, que as situações aqui relatadas mostraram-se com grade potencial para o desenvolvimento de tais aspectos e possibilitaram reflexões docentes de grande valia.

\section{REFERÊNCIAS}

[1] BRASIL. Secretaria de educação fundamental. Parâmetros Curriculares Nacionais: Matemática. Brasília: MEC/SEF, 1998

[2] CABRAL, Marcos Aurélio. A utilização de jogos no ensino de matemática. Trabalho de Conclusão de Curso. Curso de Matemática - Habilitação em Licenciatura. Universidade Federal de Santa Catarina - RS, 2006.

[3] GRANDO, R. C. (1995). O Jogo e suas Possibilidades Metodológicas no Processo Ensino Aprendizagem da Matemática. Dissertação de Mestrado em Educação - UNICAMP, Campinas.

[4] GUZMÁN, M. de. Contos com contas. Lisboa: Gradiva, 1986.

[5] KISHIMOTO, Tinuko Morchida. O jogo e a educação infantil. São Paulo: Pioneira, 1998

[6] SMOLE, Kátia Stocco. Jogos matemáticos do 1o ao 5oano. Porto Alegre: Artmed, 2007.

[7] VIGOTSKI, L.S. O desenvolvimento psicológico na infância. São Paulo, Martins Fontes, 1998 


\section{Capítulo 6}

\section{Abordagem intuitiva do conceito de área e perímetro de figuras planas através do Simulador PHET}

\section{Gisele Scremin \\ Maria Madalena Dullius \\ Italo Gabriel Neide}

Resumo: 0 presente artigo apresenta os resultados de uma prática pedagógica realizada com alunos do $3^{\circ}$ ano do Ensino Globalizado, de uma escola pública, do município de Cerro Largo/RS, produto da disciplina de Ferramentas Tecnológicas no Ensino, do Programa de Pós-Graduação em Ensino de Ciências Exatas, da Universidade do Vale do Taquari - UNIVATES. 0 objetivo deste trabalho foi desenvolver atividades que proporcionassem a compreensão de modo intuito dos conceitos de área e perímetro de figuras planas através do uso do simulador "Area Builder" do programa PhET. Para isso, a trajetória teórico-metodológica proposta partiu de uma abordagem qualitativa, sendo os dados coletados através de registros orais transcritos de gravação de áudio, de imagens e de registros escritos realizados no decorrer do trabalho em sala de aula. Através desta prática, pode-se perceber a importância e relevância do uso da tecnologia computacional aliada a atividades bem direcionadas, pois facilitam a manipulação e exploração de diferentes imagens em um contexto mais dinâmico e motivador, despertando o interesse e possibilitando a interação dos alunos tanto com o objeto em estudo, quanto com colegas e professores, favorecendo o processo de aprendizagem, em especial do conceito de área e perímetro de figuras.

Palavras-chave: Phet. Geometria. Perímetro. Área. Tecnologia. 


\section{INTRODUÇÃO}

Nas últimas décadas, o uso de tecnologias digitais da informação e comunicação (TDICs) tem crescido de maneira acelerada em toda sociedade, invadindo os espaços no campo familiar, profissional e social, o que acaba desencadeando mudanças nesses ambientes e, de modo especial, também no ambiente escolar. A presença de recursos tecnológicos cada vez mais modernos tem permitido novas formas de realizar ações, reinventando o modo com que o homem se relaciona com o mundo e com seu semelhante, e também potencializando novas formas de perceber e organizar situações de aprendizagem.

Diante desse cenário, percebe-se que o contexto educacional vem se transformando e requer a cada dia mais habilidades dos profissionais desta área, em especial, do professor. É necessário que este esteja apto a trabalhar com alunos da "era digital" e com as tecnologias disponíveis, tornando-as aliadas e parceiras do processo de ensino e aprendizagem.

As tecnologias digitais disponíveis atualmente são muitas, acessíveis, instantâneas e podem ser utilizadas para aprender em qualquer lugar, tempo e de múltiplas formas (Moran, 2004), dispondo de recursos textuais, sonoros e visuais, com facilidade de exploração. No entanto, de acordo com Dullius (2012, pag. 112) "a utilização desta ferramenta deve ocorrer de modo inteligente, pois os meios, por si sós, não são capazes de trazer contribuições para a área educacional", e também serão ineficientes caso utilizados como sendo a peça mais importante do processo educativo.

Para Valente (1997), o uso do computador de modo inteligente requer que o professor reconheça as potencialidades educacionais deste recurso, uma vez que a adoção dessa ferramenta por si só não se constitui em um diferencial positivo. Tal uso está vinculado à maneira como se concebe a tarefa na qual o equipamento será utilizado, de modo a desenvolver atividades que gerem aprendizagem. Moran (2004, $\mathrm{s} / \mathrm{p}$ ) também expressa que "a diferença não está nos aplicativos em si, mas no fato de estarem nas mãos de educadores, gestores, com uma mente aberta e criativa, capaz de fazer encantar, sonhar, de inspirar".

Diante do exposto e tendo conhecimento da importância do uso de ferramentas tecnológicas no processo de ensino e aprendizagem, propomos utilizar o simulador "Area Builder" do Repositório PhET, para desenvolver atividades que proporcionem a compreensão de modo intuitivo dos conceitos de área e perímetro de figuras planas, junto a turma de $3 \stackrel{0}{0}$ ano do Ensino Globalizado, de uma escola pública, do município de Cerro Largo/RS.

O presente artigo é também resultado dos estudos e discussões em torno do bom uso de ferramentas tecnológicas no ensino, ocorridos durante o desenvolvimento da disciplina de Ferramentas Tecnológicas no Ensino, do Curso de Pós-Graduação Stricto Sensu em Ensino de Ciências Exatas, promovido pela Universidade Do Vale do Taquari - UNIVATES, Campus de Lajeado - RS. Os estudos supracitados abordaram a necessidade de utilizar tais ferramentas, valorizando novos espaços educativos para envolver os alunos da atualidade, contribuindo, assim, para a construção de suas aprendizagens.

Nesse sentido, o estudo aqui descrito apresenta inicialmente uma fundamentação teórica acerca do uso de tecnologias no contexto educacional, passando ao contexto da aplicação e aos materiais e métodos empregados na prática desenvolvida, para, por fim, apresentar a discussão e os resultados obtidos, bem como as referências de sua fundamentação.

\section{REFERENCIAL TEÓRICO}

\subsection{O USO DE TECNOLOGIAS NO CONTEXTO EDUCACIONAL}

Os alunos que frequentam as escolas de ensino público ou privado fazem parte de uma geração que nasceu em contato com as tecnologias e descobriu o mundo por meio de diferentes mídias. 0 aluno de hoje está imerso em um mundo digital onde as tecnologias fazem parte do seu dia a dia. Eles são acostumados à velocidade, possuem comportamento multitarefa, associam a diversão à conectividade intrínseca no mundo de fantasia dos seus videogames, da televisão e, especialmente da internet. Neste mundo de possibilidades é natural que se sintam entediados no ambiente escolar tradicional (Rancam, 2011, p. 17). 
0 acesso dos alunos à informação não se limita somente ao espaço físico da sala de aula e ao uso de materiais didáticos convencionais como o livro. Hodiernamente, ele ultrapassa as fronteiras de sua cidade, estado e país, possibilitando-lhe interagir com o mundo globalizado através de um simples toque. Até mesmo crianças em fase de alfabetização têm acesso e convivem com uma imensidão de informações através da televisão, do aparelho celular, do tablet ou do computador. Haja vista que o ser humano está inserido em uma sociedade na qual a comunicação é essencialmente interativa, é deveras importante que ele não seja apenas um consumidor de informações. Aliás, a sociedade globalizada requer indivíduos que tenham consciência crítica, condições de aprender e trabalhar, habilidades em comunicar-se e expressarse através das diferentes tecnologias existentes.

Nessa perspectiva, não cabe mais à escola o papel de proporcionar aos alunos conhecimentos prontos e acabados, como se fossem verdades únicas, mas o de "tornar a informação significativa, a escolher as informações verdadeiramente importantes entre tantas possibilidades, a compreendê-las de forma cada vez mais abrangente e profunda e a torná-las parte do nosso referencial" (Moran, 2000, p. 23), proporcionando-lhes capacidades de aprendizagem que lhes permitam uma assimilação crítica da informação (Pozo e Postigo, 2000), a construção de seu próprio conhecimento, autonomia, criticidade e capacidade de analisar e de construir seu próprio ponto de vista.

Além de despertar a busca pela aprendizagem, é importante nos dias atuais também preparar os alunos para que sejam inovadores, criativos, empreendedores, cidadãos conscientes, éticos e preocupados com a sociedade. Mais do que isso, é vital ao docente que desafie e contribua para que os estudantes "estejam mais motivados, tenham mais iniciativa, explorem novas possibilidades, e as tecnologias podem ser um excelente auxiliar na tarefa de desenvolver esse aluno mais crítico e inovador. (Moran, 2004, pag. 349)

Assim, as tecnologias precisam ser vistas como apoio, como meios que permitem a realização de atividades de aprendizagem de forma diferente da até então praticada (Pozo, 2004), possibilitando a criação de situações de aprendizagens ricas, complexas, diversificadas.

O computador, em particular permite novas formas de trabalho, possibilitando a criação de ambientes de aprendizagem em que os alunos possam pesquisar, fazer antecipações e simulações, confirmar ideias prévias, experimentar, criar soluções e construir novas formas de representação mental (Brasil, 1998).

Entretanto, sua implantação para atividades escolares requer ainda muita reflexão. Segundo Dullius (2012, pag. 112) " os recursos tecnológicos podem ser utilizados de forma a agregar saberes e não simplesmente com o intuito de ocupar o tempo ou "divertir" os alunos". Nesse sentido, percebe-se a importância de um uso inteligente, planejado e definido desses recursos e, para isso, é necessário que os professores estejam preparados, que saibam de fato utilizá-los de maneira crítica na prática escolar, que percebam a importância de preparar as aulas, de conhecer e selecionar bem o recurso a ser empregado (Kaiber, Conceição, 2007). E ainda, segundo Lopes

[...] se um dos objetivos do uso do computador no ensino for o de ser um agente transformador, o professor deve ser capacitado para assumir o papel de facilitador da construção do conhecimento pelo aluno e não um mero transmissor de informações (2004, p. 4).

Desse modo, para que a incorporação das tecnologias nas práticas pedagógicas seja adequada e promova uma mudança educacional, os docentes precisam conhecer essa ferramenta de transformação, uma vez que é fundamental o seu papel como mediador da utilização desses recursos em aula. É importante, também, que o professor repense sua prática e utilize/construa estratégias/ metodologias inovadoras, capazes de promover a construção do conhecimento, em que o aluno seja protagonista. Isso como forma de tornar relevante o uso de tecnologias em sala de aula, promovendo um diferencial nos processos de ensino e de aprendizagem.

\section{MATERIAS E MÉTODOS}

O presente estudo efetivou-se com a participação dos alunos de uma turma de terceiro ano do ensino globalizado. A faixa etária dos alunos é de 8 a 9 anos, sendo que a turma conta com 15.

A primeira autora desenvolveu as atividades junto à uma escola pública, do município de Cerro Largo, utilizando dois notebooks próprios e seis da escola para desenvolver o trabalho, devido à instituição não contar com sala de informática. 
Neste estudo, adotou-se a pesquisa qualitativa, com caráter exploratório. A abordagem qualitativa vem se firmando e mostrando-se promissora possibilidade de investigação em pesquisas realizadas na área de educação, caracterizando-se pelo enfoque interpretativo da realidade. (Erickson, 1989).

Godoy (1995) explicita algumas características principais de uma pesquisa qualitativa, o que embasa também este trabalho:

"considera o ambiente como fonte direta dos dados e o pesquisador como instrumento chave; o processo é o foco principal de abordagem e não o resultado ou o produto; a análise dos dados foi realizada de forma intuitiva e indutivamente pelo pesquisador; não requereu o uso de técnicas e métodos estatísticos; e, por fim, teve como preocupação maior a interpretação de fenômenos e a atribuição de resultados". (Godoy, 1995, p.58)

Assim, a coleta de dados foi realizada através da observação participante, pois atuou-se como professorapesquisadora. Sobre o método de pesquisa qualitativa, considerou-se, ainda, que ele possibilita ao pesquisador aprender mais sobre as atividades das pessoas em seu contexto natural, através da observação e participação nessas atividades (Kawulich, 2005). Nesse sentido, há também a possibilidade de o pesquisador compartilhar experiências não somente observando, mas sentindo (Saunders, Lewis e Thornhill, 2000), aspectos esses que podem ser apontados como vantagens de se utilizar a investigação qualitativa para a situação de estudo proposta.

$\mathrm{Na}$ abordagem de pesquisa valorizou-se, portanto, o contato direto e prolongado do professorpesquisador com o ambiente e a situação que estava sendo estudada. De modo que, para o registro das observações foram utilizados a gravação de áudios e o registro fotográfico. Como instrumentos para coleta de dados também foram utilizados o diário de campo.

0 processo de análise e discussão dos dados coletados esteve ancorado nos pressupostos da análise de conteúdo, que, de acordo com Bardin (2009), tem por objetivo a manipulação de mensagens (conteúdo e expressão deste conteúdo). Trata-se de

[...] um conjunto de técnicas de análise das comunicações, visando obter por procedimentos sistemáticos e objetivos de descrição do conteúdo das mensagens indicadores (quantitativos ou não) que permitam a inferência de conhecimentos relativos às condições de produção/recepção [...] destas mensagens (Bardin, 2009, p. 44).

A proposta didática para este estudo, composta por 4 momentos sequenciais, foi realizada em um encontro com duração de 4 horas/aula, sendo iniciada a partir do uso das figuras da Imagem 1.

Imagem 1: Figuras construídas no Simulador

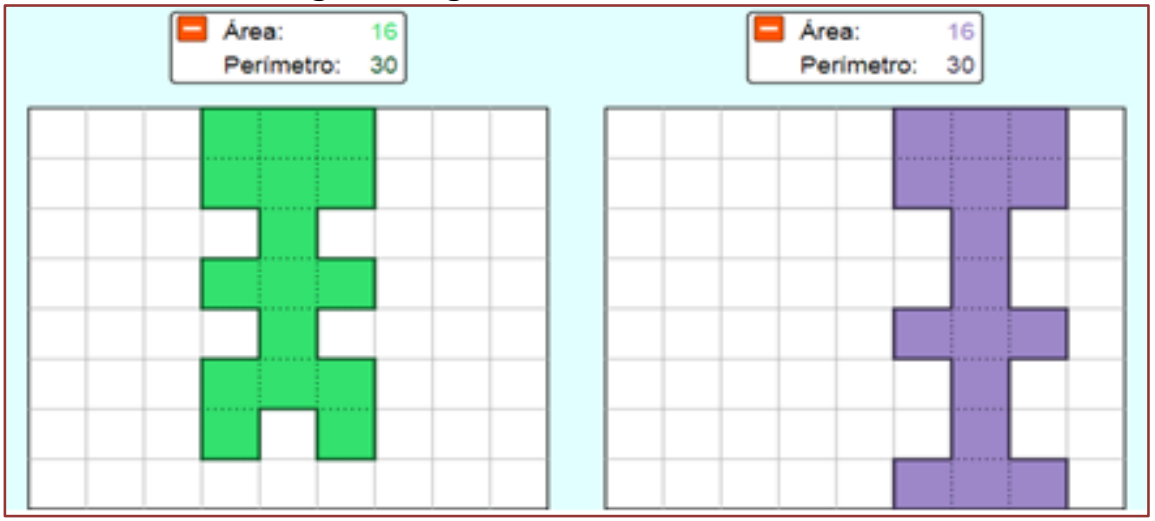

Fonte: Arquivo pessoal das Autoras

Com o objetivo principal de explorar o conceito intuitivo de perímetro e área de figuras planas através do uso do simulador "Area Builder" do repositório PHET, a prática consistiu no desenvolvimento da atividade nos momentos apresentados na sequência. 
Quadro 1 - Momentos das Atividades Propostas

\begin{tabular}{|c|c|c|}
\hline Momento & Objetivos & Atividades \\
\hline Momento 1 & $\begin{array}{l}\text { Quantificar os quadrados pintados das } \\
\text { figuras } 1 \text { e } 2 \text {; Reconhecer os lados que } \\
\text { compõem as figuras e relacionar a } \\
\text { quantidade de quadrados que formam } \\
\text { estes lados. }\end{array}$ & $\begin{array}{l}\text { Quantos quadrados estão pintados na figura A? E na } \\
\text { figura B? Conte quantos são os lados dos } \\
\text { quadradinhos que fazem parte do lado de fora da } \\
\text { figura A? E da figura B? OBS: Expor os resultados } \\
\text { obtidos pelos alunos no quadro. }\end{array}$ \\
\hline Momento 2 & $\begin{array}{l}\text { Explorar diferentes figuras com a } \\
\text { mesma quantidade de quadrados } \\
\text { (área) e mesmo perímetro; Diferenciar } \\
\text { o contorno das figuras do espaço } \\
\text { ocupado por ela; Explorar o conceito } \\
\text { de área que está representada no } \\
\text { simulador pela parte pintada; Explorar } \\
\text { o conceito de perímetro que está } \\
\text { representado nesse simulador pelo } \\
\text { contorno da figura. }\end{array}$ & $\begin{array}{l}\text { A partir dos quadradinhos existentes, construa outra } \\
\text { figura de acordo com a sua criatividade. Mudou a } \\
\text { quantidade de quadradinhos? Por que essa } \\
\text { quantidade não mudou? Descrever, no quadro } \\
\text { branco, as respostas dos alunos. E agora, vamos ver a } \\
\text { quantidade de lados da parte de fora das figuras. } \\
\text { Mudou ou não? Descrever, no quadro branco, as } \\
\text { respostas dos alunos }\end{array}$ \\
\hline Momento 3 & $\begin{array}{l}\text { Analisar quais figuras que possuem a } \\
\text { mesma área podem não ter o mesmo } \\
\text { perímetro e vice-versa. }\end{array}$ & $\begin{array}{l}\text { Na tela } 1 \text { do simulador, construa uma figura que } \\
\text { tenha área (parte pintada) igual a } 20 \text {. Qual o seu } \\
\text { perímetro (contorno dos lados da figura)? Na tela } 2 \\
\text { do simulador, construa outra figura com a mesma } \\
\text { quantidade de quadradinhos. E agora, o perímetro é o } \\
\text { mesmo? Na tela } 1 \text { construa uma figura que tenha } \\
\text { perímetro (contorno dos lados da figura) igual a } 18 . \\
\text { Qual a área (parte pintada) dessa figura? Na tela } 2 \\
\text { construa outra figura com o mesmo perímetro. E } \\
\text { agora, qual a sua área? }\end{array}$ \\
\hline Momento 4 & $\begin{array}{l}\text { Possibilitar a interação dos alunos com } \\
\text { o programa e o conteúdo desenvolvido. }\end{array}$ & $\begin{array}{l}\text { Construção de um desenho utilizando o simulador. } \\
\text { Utilização do Game que consta no próprio simulador, } \\
\text { para verificar se os conceitos trabalhados foram } \\
\text { compreendidos. OBS: Deverá ser analisado pelo } \\
\text { professor até qual nível os alunos serão capazes de } \\
\text { resolver as atividades do game. }\end{array}$ \\
\hline
\end{tabular}

Fonte: Elaborado pelas autoras

\section{APLICAÇÃO DAS ATIVIDADES}

Nos Parâmetros Curriculares Nacionais do Ensino Fundamental (PCN), na área de Matemática, encontramse como referência alguns caminhos para fazer Matemática na sala de aula. Entre os caminhos apontados consta o recurso às tecnologias da informação, destacando que " o computador pode ser usado como elemento de apoio para o ensino (banco de dados, elementos visuais), mas também como fonte de aprendizagem e como ferramenta para o desenvolvimento de habilidades (Brasil,1997) ".

Nesse contexto, ciente da importância do uso inteligente da tecnologia na educação, com destaque ao aprendizado da matemática, desenvolveram-se as atividades com uso do simulador "Area Builder". Assim, com o intuito de oportunizar a comparação entre diferentes elementos que compõem uma figura plana (quadriláteros), observar, diferenciar e relacionar atributos nas imagens que influenciam em seu formato, neste caso, o contorno de seus lados e a quantidade de quadradinhos pintados, as atividades primaram por promover a investigação e a descoberta.

Frente à condição da autora um e proponente da atividade de pesquisa ser a de não se encontrar em sala de aula atualmente, foi necessário buscar um espaço para o desenvolvimento da prática. Já contando com parcerias anteriores, buscou-se o diálogo com a professora regente da classe, na escola supracitada, a qual de pronto autorizou a realização da prática em sua turma. Aliás, consideraram importante a oportunidade de inclusão da tecnologia no contexto educacional de suas turmas, externando que não o fazem devido ao pouco contato e conhecimento a respeito dessa prática até o momento. Vislumbraram, ainda, como sendo uma oportunidade para explorar um ambiente diferente do habitual aos alunos.

\section{RESULTADOS E DISCUSSÃO}

Na análise e discussão dos dados, optamos por explorar cada momento das atividades, de modo a ressaltar a importância de cada uma delas no processo de ensino e aprendizagem. Para iniciar as atividades, a professora mostrou a imagem de duas figuras impressas feitas no simulador (apresentadas acima na 
Imagem 1), as quais solicitou que os alunos em duplas e trio reproduzissem no simulador, o que eles realizaram com facilidade.

Na sequência, começou-se a questionar os alunos sobre a aparência das figuras, se eram iguais ou diferentes, e o que tinham em comum. Os alunos responderam que ambas eram diferentes, mas possuíam cabeça, mãos e pernas iguais. Aproveitando a resposta solicitou-se que contassem o número de quadradinhos de cada figura, ao que os alunos obtiveram como resposta 16 quadrinhos. Neste instante, alguns alunos já haviam se dado conta de que a quantidade de quadradinhos estava relacionada à palavra área do simulador, comentando no grupo, embora alguns ainda não houvessem percebido a relação.

Para continuar a exploração das imagens, partiu-se à contagem dos lados de fora dos quadradinhos que formavam cada figura. Nesse momento da atividade, alguns alunos logo relacionaram a quantidade com a palavra perímetro no simulador e responderam rapidamente, enquanto outros estavam em dúvida sobre quais seriam esses lados. Frente a isso, a professora dirigiu-se até as imagens, mostrando quais seriam os lados dos quadradinhos que formavam as figuras, aproveitando para questionar os alunos sobre se realmente a palavra perímetro estava relacionada a essa quantidade, convidando-os a realizarem a contagem.

Dando continuidade, os alunos responderam que o número de lados dos quadradinhos que formavam a parte de fora das figuras era de 30, confirmando a afirmação levantada por alguns de seus colegas referente à relação entre o contorno das figuras e a palavra perímetro. Finalizando este primeiro momento, realizou-se a contagem do contorno dos lados das figuras e da quantidade de quadradinhos, no grande grupo, socializando a questão da área e do perímetro e a relação com as figuras, de modo que todos os alunos tivessem a oportunidade de expressar sua opinião, sendo a quantidade escrita no quadro pela professora, conforme a Imagem 3.

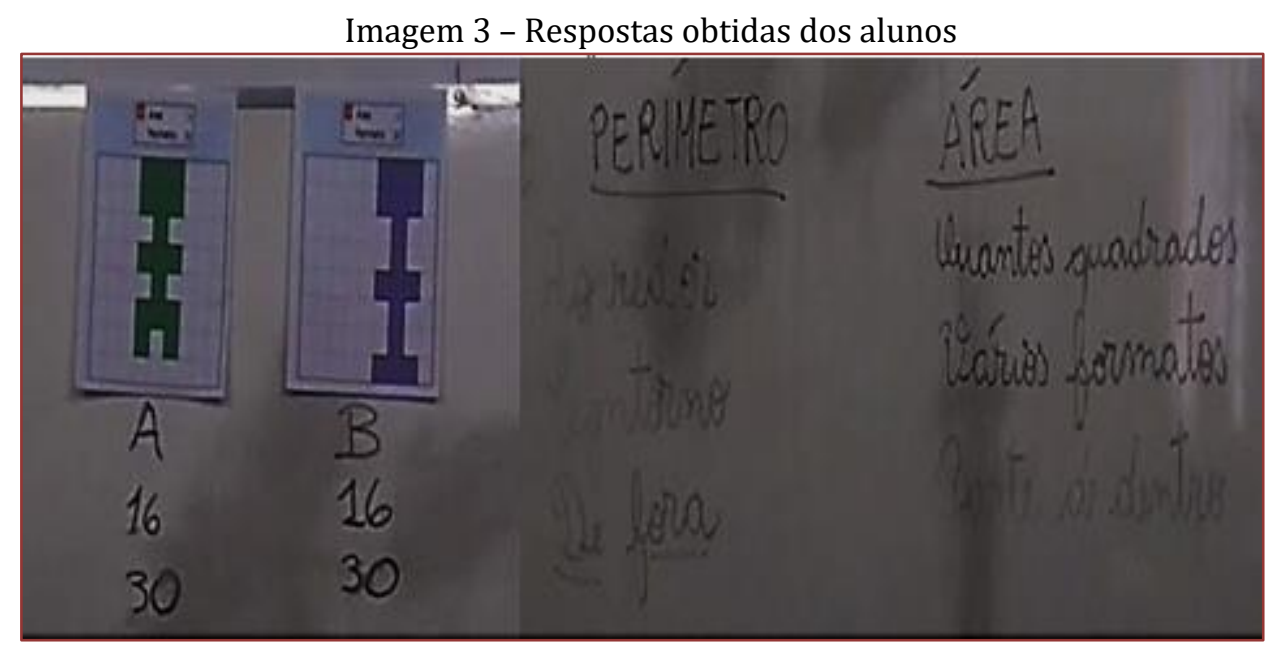

Fonte: arquivo pessoal da autora um.

É notável que, ao passo que se desenvolveu a primeira atividade, foi necessário que a professora assumisse uma postura de mediadora e questionadora frente ao uso do simulador, para que os alunos, de acordo com Valente (1995, pag.43) "pudessem passar do nível do fazer para o compreender", utilizando o computador como uma ferramenta pedagógica.

No segundo momento, solicitou-se a criação de novas figuras através das já construídas anteriormente, de modo a conduzir o aluno à percepção e compreensão de que, possuindo a mesma área, uma figura pode ter um perímetro diferente, e vice-versa. Aproveitando a atividade, a professora passou em cada dupla e trio para registrar as figuras criadas, conforme pode ser observado na Imagem 4, e questionou os alunos sobre o que havia mudado nas figuras, além do formato, e porquê.

Diante do questionamento, noventa por cento dos alunos responderam que a quantidade não havia mudado, pois não haviam colocado nem tirado quadradinhos, de modo que as novas figuras mantiveram a mesma área das anteriores. No entanto, destacaram que o perímetro era outro, pois as figuras haviam mudado de formato. Nesse momento, uma dupla ainda manifestava dúvida, sendo necessárias a mediação e retomada da atividade com eles para que pudessem compreender os conceitos e acompanhar o desenvolvimento das demais atividades. Desse modo, ficou clara a importância de o professor acompanhar o andamento do processo e realizar as devidas intervenções quando necessário. 
Imagem 4 - Figuras criadas pelos alunos com área 16
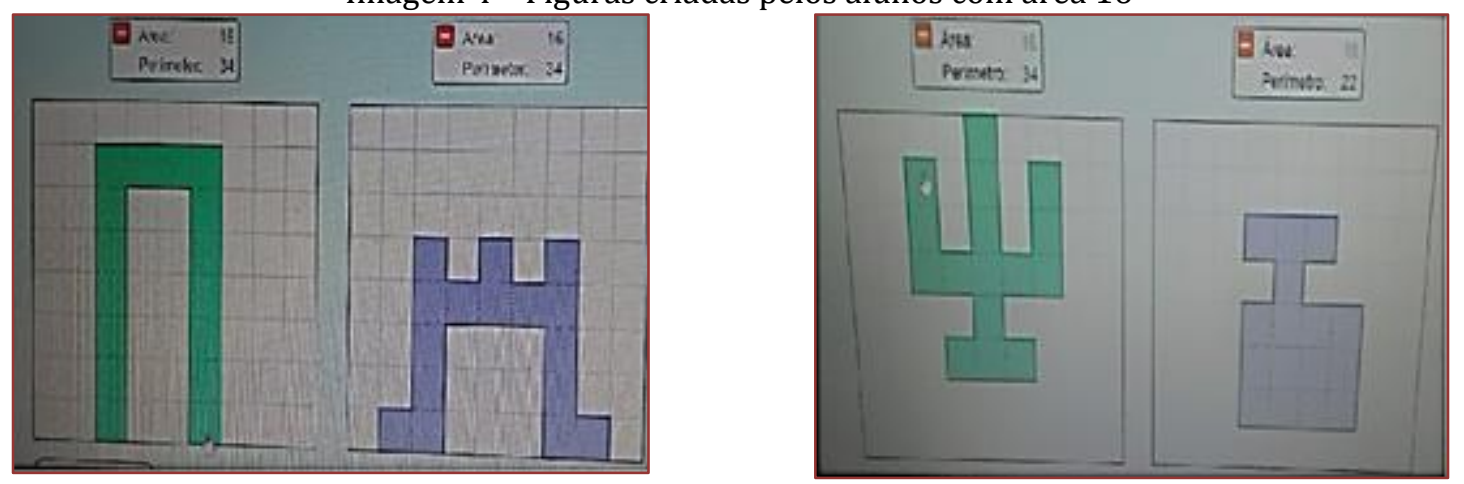

Fonte: Arquivo pessoal da autora um

Neste enfoque, a utilização do computador como ferramenta oferece aos alunos a oportunidade de aprender, de expressar suas ideias, tendo autonomia, ao invés de ser ensinado, corroborando com Valente (1995) sobre a possibilidade de construção de conceitos e o desenvolvimento de habilidades constituindo uma mudança/transformação no processo educacional.

No terceiro momento, após a compreensão de que figuras podem ter mesma área e perímetros diferentes, solicitou-se a construção de outras duas figuras, agora com área 20, deixando livre a escolha do formato e perímetro a serem obtidos. Com essa atividade foram exploradas as possibilidades de obtenção de diferentes perímetros para uma mesma área, oportunidade em que os alunos puderam transitar pela sala e observar as figuras dos colegas. Na sequência solicitou-se que construíssem duas figuras com perímetro 18. Do mesmo modo foram exploradas as figuras obtidas e a área das mesmas, sendo que alguns conseguiram fazer figuras diferentes com mesmo perímetro, enquanto outros optaram por fazer diferentes figuras e obter áreas também diferentes.

Diante da possibilidade de criar e explorar objetos, oportunizados pelo uso do computador, os alunos tornam-se mais participativos e tem a oportunidade de experimentar, testar, observar, assumindo papel ativo em sala de aula, corroborando com as ideias expressas por Martins $(1998$, p. 247) sobre o uso do computador como "uma máquina que possibilita a criação, manipulação e execução simbólica de objetos. Se inserido num ambiente de experimentação, pode possibilitar o indivíduo "dar formas as suas ideias" analisa-las e modifica-las".

Para concluir as atividades, os alunos tiveram a oportunidade de realizar um desenho livre no simulador, de maneira a instigar a criatividade e a descoberta, sempre tentando relacionar a área e o perímetro obtidos através das figuras construídas. Após esse momento de muita criatividade demonstrada pelos alunos, solicitou-se o acesso ao game do simulador, para que fosse possível avaliar se os conceitos trabalhados realmente foram compreendidos. Explicou-se, então, o primeiro desafio, sendo possível observar que todos haviam entendido, pois começaram a jogar e passar de nível muito rapidamente, o que surpreendeu a professora.

Na finalização da aula questionou-se sobre quais objetos da sala de aula poderíamos calcular a área e perímetro, e supreendentemente as respostas vieram:

Alunos: "Do quadro branco, do mapa-múndi, do mural, da mesa, do armário, das nossas classes, da porta, da tela do computador."

Então aproveita-se para seguir questionando:

Professora: "Mas como medir a área, levando em conta o que fizemos hoje?

Alguns alunos: " Podemos dividir em quadrados e contar quantos tem."

Professora: " Ótimo. Mas como medimos as coisas?"

Alunos: "Em metro; com a régua, em centímetros."

Ainda se questionou sobre o perímetro. Apontando para o quadro branco, indagou-se como seria possível calcular o seu perímetro. Obteve-se, então, como resposta, que seria necessário contar os lados do objeto. 
A partir da discussão final e da realização do game pôde-se perceber a importância e relevância da utilização do simulador para o estudo inicial dos conceitos de área e perímetro, o que em muitas vezes é apresentado com fórmulas prontas e acabadas aos alunos, dificultando sua compreensão e ignorando sua aplicabilidade. 0 "aprender fazendo" ideia evocada por Papert e por outros autores, aparece como uma das possibilidades do uso do computador como ferramenta educacional, pois oferece subsídios para que os alunos tenham um ambiente de aprendizagem diferenciado e que possibilita o construir e criar, e deste modo permite o aluno engajar-se na atividade.

\section{CONSIDERAÇÕES FINAIS}

Através da realização deste trabalho prático de ensino e aprendizagem de conceitos básicos matemáticos com a utilização de ferramenta tecnológica em diferentes contextos educacionais pode-se afirmar que o uso das tecnologias com finalidade educacional/pedagógico amplia as possibilidades de trabalho do professor ao conduzir seus alunos e o processo de ensino, assim como possibilita um modo diferente de aprender ao aluno. Quando utilizada com clareza e critério pelo educador, a tecnologia pode contribuir para a aprendizagem e na melhoria do processo de ensino e aprendizagem.

No entanto, é necessário que o professor busque conhecer e estar consciente de que esse uso tecnológico na área educacional tem reflexos em sua prática docente que, como reforçado neste trabalho, precisa ser cuidadosamente planejada. Da mesma forma, interfere na condução para apropriação de conhecimentos, uma vez que se permuta a figura do professor que ensina, demonstra e explica conceitos e conhecimentos, pela do docente que instiga e orienta a dedução dos fatos a serem aprendidos pelos alunos, para que estes construam o conhecimento. Além de que, aumenta o interesse, a participação e a motivação dos alunos, cabendo destacar que se desenvolve nos pequenos o espírito investigativo, encorajando-os a concluírem a partir das suas hipóteses e investigações/experimentações, evidenciando o aspecto significativo da aprendizagem que se constrói. Aspecto esse que ficou evidente na prática descrita, em que os alunos participaram ativamente, facilitando a problematização dos conteúdos e tornando a aula mais produtiva e dinâmica, assumindo eles - alunos - o papel de protagonistas e o professor, o de mediador e questionador.

\section{REFERENCIAS}

[1] Bardin, Laurence. Análise de Conteúdo. Tradução de Luís A. Reto e Augusto Pinheiro. 5ed. Lisboa: Edições 70, 2009.

[2] Brasil. Ministério da Educação. Secretaria de Educação Fundamental. Parâmetros Curriculares Nacionais: matemática. Disponível em: <http://portal.mec.gov.br/seb/arquivos/pdf/matematica.pdf>. Acesso em: 04 ago. 2018.

[3] Dullius, Maria. M. Tecnologias no ensino: por que e como? Caderno pedagógico, Lajeado, v. 9, n. 1, p. 111-118, 2012. Acesso em: 10 ago. 2018. Disponível em: www.univates.br/revistas/index.php/cadped/article/view/849/838.

[4] Erickson, F. (1989). Métodos cualitativos de investigación sobre la enseñanza. In M. Wittrok (Ed.), La investigación de la enseñanza II. Métodos cualitativos de observación. Barcelona: Paidós MEC. Pp. 203-47.Disponível em: https://fcsalud.ua.es/es/documentos/planes-de-estudio/doctorado/actividad-7/lectura-1.pdf . Acesso em: 18 out. 2017.

[5] Godoy, Arilda. S. Introdução à pesquisa qualitativa e suas possibilidades. In: Revista de Administração de Empresas. São Paulo: v.35, n.2, p. 57-63, abr. 1995. Disponível em: http://www.scielo.br/pdf/rae/v35n2/a08v35n2.pdf. Acesso em 19 out. 2017.

[6] Litwin, E. Tecnologia educacional: Política, História e Proposta. Porto Alegre: Artmed, 1998.

[7] Kawulich, Barbara. B. Participant observation as a data collection method. Forum: Qualitative Social Research [On-line journal]. v. 6, n. 2, art. 43. 2005. Disponível em: http://www.qualitativeresearch.net/index.php/fqs/article/view/466/997. Acesso em: 03 ago. 2018.

[8] Kaiber, Carmen. T., Conceição, Cristiano. P. da. Softwares educativos e o ensino da trigonometria. Educação Matemática em Revista -RS. v. 8, n. 8, p. 37-50, 2007.

[9] Martins, Maria. C. O fazer musical em um contexto computacional. Computadores e conhecimento: repensando a educação/ José Armando Valente, organizador - 2ª ed., Campinas/SP: UNICAMP/NIED, 1998.

[10] Moran, José. M. Ensino e aprendizagem inovadores com tecnologias. Informática na Educação: Teoria \& Prática. Porto Alegre, vol.3, n.1 (set. 2000) UFRGS. Programa de Pós-Graduação em Informática na Educação, pag. 137144. Disponível em:< http://www.pucrs.br/ciencias/viali/tic_literatura/artigos/tics/Ensino\%20e\%20aprendizagem\%20inovadores\%20c om\%20tecnologias.pdf>. Acesso em: 15 ago. 2018 
[11] Moran, José. M. A contribuição das tecnologias para uma educação inovadora. Revista Contrapontos, Itajaí, SC., v. 4, n. 2, p. 347-356, mai/ago. 2004.Disponível em: <https://siaiap32.univali.br/seer/index.php/rc/article/view/785>. Acesso em: 05 ago. 2018.

[12] Pozo, Juan. I.; Postigo, Yolanda. A. Los procedimientos como contenidos escolares: uso estratégico de la información. Barcelona: Edebé, 2000. Disponível em: < https://des-

for.infd.edu.ar/sitio/upload/los_procedimientos_como_contenidos_escolares-_POZO.pdf>. Acesso em: 12 ago. 2018.

[13] Pozo, Juan. I. A sociedade da aprendizagem e o Desafio de converter informação em conhecimento. Revista Pátio, ano 8, agosto/outubro 2004. Disponível em: <

http://www.franciscoqueiroz.com.br/portal/phocadownload/NovasTecnologias/a\%20sociedade\%20da\%20aprendi zagem $\% 20 \mathrm{e} \% 20 \mathrm{o} \% 20$ desafio $\% 20 \mathrm{de} \% 20$ converter\%20informao\%20em\%20conhecimento.pdf>. Acesso em: 27 jul. 2018.

[14] Rancan, Graziele. Origami E Tecnologia: Investigando Possibilidades Para Ensinar Geometria No Ensino Fundamental. Porto Alegre, RS, 2011, 80f. Dissertação (Mestrado em Ciências e Matemática) - Faculdade de Física PUCRS, Porto Alegre, RS. Disponível em: <http://repositorio.pucrs.br/dspace/bitstream/10923/3101/1/000436223Texto\%2BCompleto-0.pdf>. Acesso em 26 jul 2018.

[15] Saunders, Mark. N. K.; Lewis, Philip; Thornhill, Adrian. Research methods for business students. England: Pearson Education, $\quad 2000$ https://eclass.teicrete.gr/modules/document/file.php/DLH105/Research\%20Methods\%20for\%20Business\%20Stud ents\%2C\%205th\%20Edition.pdf>. Acesso em: 23 jul. 2017.

[16] Thiollent. Michel. Metodologia da Pesquisa - ação. São Paulo, Cortez Editora, 1985. Disponível em: https://docslide.com.br/documents/thiollent-michel-metodologia-da-pesquisa-acao-sao-paulo-cortez-1998.html. Acesso em: 18 out. 2017.

[17] Valente, Jose. A. 0 uso inteligente do computador na educação. Revista Pátio. Ano I, n. 1, mai/jul, 1997. Disponível em: http://www.pucrs.br/ciencias/viali/tic_literatura/artigos/usointeligente.pdf. Acesso em 04 ago. 2018. 


\section{Capítulo 7}

Ensino de vetores: Sequência didática fundamentada na engenharia didática

\section{César Marcos do Nascimento Lucas}

Raimundo Nonato Barbosa Cavalcante

Resumo: 0 presente artigo apresenta a construção, realização, observação e análise de uma Sequência Didática (SD) fundamentada nas etapas da Engenharia Didática (ED). Para a SD escolhemos o objeto matemático vetor, com foco na aprendizagem do conceito de vetor a partir da ideia de segmento orientado. Nas etapas iniciais da ED, análises preliminares e concepção e análise a priori, identificamos dificuldades com relação à aprendizagem do assunto abordado e que a exploração das Representações Semióticas (RS) dos vetores, potencializada pela utilização do Geogebra, pode facilitar a aprendizagem desse conteúdo matemático. Nas etapas finais da ED, comprovamos algumas hipóteses levantadas durante a construção da SD, como o nível de conhecimento em relação ao objeto matemático vetor e que atividades, explorando as representações semióticas dos vetores com o auxílio do Geogebra, podem contribuir para o ensino dos vetores.

Palavras-chave: Engenharia Didática; Sequência Didática, Vetores, Representações Semióticas, Geogebra. 


\section{INTRODUÇÃO}

A preocupação com o ensino-aprendizagem do objeto matemático vetor surgiu com a prática enquanto docente do Ensino Médio e intensificou-se durante o Mestrado Profissional em Matemática em Rede (PROFMAT). Lecionando Geometria Analítica para Licenciatura em Matemática, comprovamos as deficiências apresentadas pelos discentes com relação a este Objeto Matemático - OM. Consideramos a importância desse objeto matemático tanto para aplicação em outros assuntos abordados no Ensino Médio, como em Geometria e Física, quanto para o estudo de outros tópicos da Matemática Superior, como a Álgebra Linear.

Baseando-se no exposto acima, realizamos uma Sequência Didática - SD fundamentada na Engenharia Didática - ED. Para a SD, escolhemos o OM vetor, com foco na aprendizagem do conceito de vetor a partir da ideia de segmento orientado.

Nas etapas iniciais da ED, a saber: análises preliminares e concepção e análise a priori verificamos o baixo nível de conhecimento sobre o OM considerado e identificamos que a exploração das Representações Semióticas - RS dos vetores, potencializada pela utilização do Geogebra, pode facilitar a aprendizagem deste $\mathrm{OM}$ e construímos a SD.

Na etapa de experimentação e de análise a posteriori e validação aplicamos a SD e, mediante observação das atividades desenvolvidas pelos alunos, comprovamos algumas hipóteses, como o baixo conhecimento dos alunos com relação ao objeto matemático vetor e a importância da exploração das Representações Semióticas para a compreensão do conceito de vetores.

\section{METODOLOGIA}

0 presente trabalho representa uma pesquisa de natureza qualitativa de caráter experimental, na qual é utilizada a Engenharia Didática como metodologia, tendo como sujeitos da pesquisa alunos de uma turma de Geometria Analítica, disciplina ofertada no início da Licenciatura em Matemática. Contamos com teste diagnóstico, aulas de nivelamento e posterior aplicação da metodologia no ensino de vetores quando também contamos com aulas no laboratório de informática para visualização e manipulação de vetores com o software de Geometria Dinâmica, o Geogebra.

Para a realização deste trabalho, as análises preliminares foram realizadas mediante pesquisa bibliográfica, buscando autores que fizeram estudos sobre a ED e/ou sobre o objeto matemático em questão, tentando identificar elementos que pudessem contribuir para a construção da SD. Dentre as leituras realizadas, destacamos Alves (2016); Bittar (2003); Damm (2012); Lucas (2017); Machado (2012) e Martins (2015). Dentre os autores consultados, identificamos alguns elementos que podem contribuir para a construção da segunda etapa da ED. Tais elementos serão descritos a seguir:

(1) - Existe uma multiplicidade de formas e formalizações em torno da noção de vetor (vetor da física, vetor geométrico e vetor elemento de um espaço vetorial). Tal multiplicidade implica o uso de diferentes linguagens, representações e modos de pensar.

(2) - Os vetores são de extrema importância como objeto matemático, como facilitador para resolução de problemas da Geometria e para estudos de disciplinas do Ensino Superior, como Álgebra Linear.

(3) - Dada a importância das representações desse objeto matemático e as atividades de tratamento e conversão (Duval, 2003), o Geogebra torna-se um potencializador para o ensino desse conteúdo.

Na figura 1 temos representações de vetores e aplicações. Da esquerda para direita temos: um vetor, representado no registro figural, apresentado módulo, direção e sentido; os vetores u e v representados nos registros figural e algébrico; paralelepípedos com arestas adjacentes representadas por vetores, calculando o produto misto entre os vetores obtêm-se o volume do paralelepípedo. 
Figura 1. Vetores e aplicações

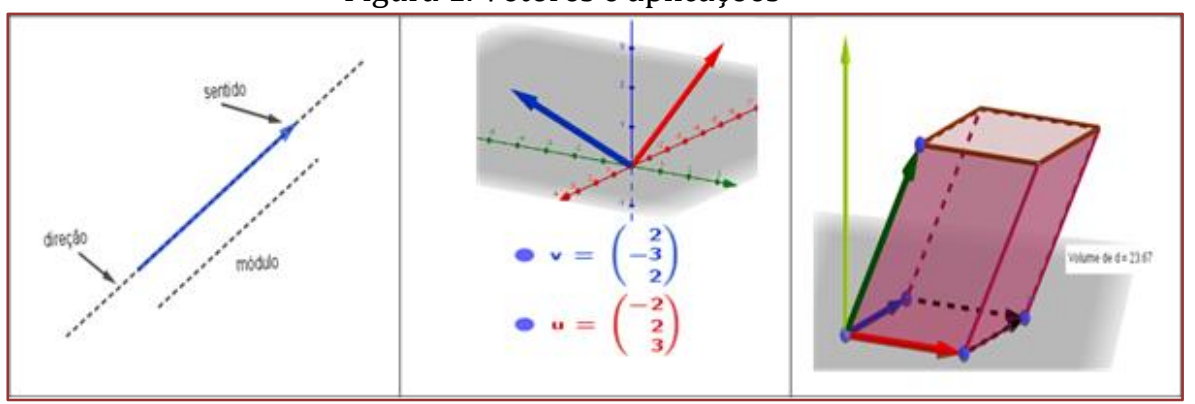

Fonte: Elaborada pelo autor.

Diante dos elementos identificados na primeira fase, elaboramos a segunda fase da ED: concepção e análise a priori. Nesta etapa da ED, foram elaborados o teste diagnóstico e a atividade (conceito de vetor), que foram aplicados na etapa seguinte da ED.

Com o teste diagnóstico, pretendeu-se saber se o aluno era capaz de fazer conversões entre os Registros Algébricos (Representação Numérica e Representação Vetorial), Registro Figural (Representação Gráfica e Representação Geométrica) e Registro da Língua Natural (Representação da Língua Natural), e se dentro de cada registro conseguiam fazer os devidos tratamentos. A atividade (conceito de vetor) foi elaborada para explorar o conceito de vetor a partir da ideia de segmento orientado. Com a realização da atividade, 0 aluno estará visualizando diversos representantes de um vetor em duas de suas representações, a algébrica e a geométrica.

A etapa de experimentação deu-se com aplicação do teste diagnóstico e aplicação da SD. Com o teste diagnóstico, percebemos que muitos alunos não conseguiram resolver os problemas propostos por não saberem realizar atividades de conversão. Problemas em que o registro era diferente do registro de chegada foram, na maioria dos casos, deixados sem resposta pelos alunos.

A aplicação da SD foi realizada no Laboratório de Informática. Como nem todos conheciam o Geogebra, dispomos de uma aula para apresentar as noções básicas e que seriam aplicadas na realização da atividade proposta. Durante a realização da atividade, percebemos uma motivação dos alunos por estarem em um ambiente "diferente" do tradicional, experimentando, explorando o aspecto visual do objeto matemático em questão. Sempre que necessário, intervimos para fazer o aluno refletir sobre as representações e sobre os processos de tratamento e conversão.

Na quarta etapa da ED, com a aplicação do teste diagnóstico, concluímos nossas hipóteses. Boa parte dos alunos chega ao ensino superior sem noções básicas do conceito de vetores. Com a realização da atividade, verificamos o quanto é importante a aplicação do Geogebra para o ensino de vetores, possibilitando que o estudante explore a visualização para a formação de conceitos ao invés de somente realizar processos algorítmicos.

\section{DESENVOLVIMENTO}

O ensino de vetores na disciplina de Matemática ainda não faz parte da maioria das Escolas de Educação Básica, no entanto, pesquisas diversas direcionam para a necessidade de inserir este assunto no currículo de Matemática, seja como objeto matemático ou como uma ferramenta para aplicação a outros tópicos do Ensino Médio, como Geometria Analítica e Geometria Espacial.

Em sua dissertação de mestrado, Cabral (2014) aborda uma proposta do estudo de vetores no plano e no espaço no $3^{\text {o }}$ ano do ensino médio como uma perspectiva de um ganho para os estudos Geometria Analítica. A autora relata que no estudo da disciplina de Geometria Analítica, no Mestrado Profissional de Matemática (PROFMAT), "verificou-se que a introdução do estudo de vetores é de simples compreensão e uma ferramenta poderosa para a Geometria Analítica" (Cabral, 2014, p.06). Os ganhos seriam relativos a uma melhora na visualização de alinhamento e três pontos, da equação da reta e de seus vetores tangentes e normais, além de simplificar a resolução de exercícios.

A maneira como os vetores devem ser abordados no Ensino Médio é citada nas Orientações Curriculares para o Ensino Médio, documento elaborado pelo Ministério da Educação e publicado em 2006. Segundo este documento: 
"É desejável, também, que o professor de Matemática aborde com seus alunos o conceito de vetor, tanto do ponto de vista geométrico (coleção dos segmentos orientados de mesmo comprimento, direção e sentido) quanto algébrico (caracterizado pelas suas coordenadas). Em particular, é importante relacionar as operações executadas com as coordenadas (soma, multiplicação por escalar) com seu significado geométrico. A inclusão da noção de vetor nos temas abordados nas aulas de Matemática viria corrigir a distorção causada pelo fato de que é um tópico matemático importante, mas que está presente no ensino médio somente nas aulas de Física." (OCEM, 2006, p.77).

Percebemos que muitos alunos terminam o ensino médio sem o devido conhecimento sobre o conceito de vetor, e destes, alguns passam a cursar uma licenciatura em Matemática e sentem grandes dificuldades ao cursarem uma disciplina como Geometria Analítica.

Para a construção da SD adotamos a ED como metodologia de pesquisa. Essa metodologia que vem sendo utilizada em pesquisas experimentais desde a década de 1980, tendo como finalidade analisar situações didáticas, objeto de estudo da Didática da Matemática (Cf. Machado, 2012, p. 233).

Artigue (1988) apud Machado (2012, p. 235) caracteriza a Engenharia Didática [...] como um esquema experimental baseado sobre "realizações didáticas" em sala de aula, isto é, sobre a concepção, a realização, a observação e a análise de sequências de ensino.

A ED é organizada em quatro fases: análises preliminares, concepção e análise a priori, experimentação e análise a posteriori e validação. Faremos um resumo das fases, de acordo com Machado (2012).

- Primeira Fase: análises preliminares. É a fase de embasamento da concepção da engenharia, feitas através de levantamento bibliográfico, fazendo considerações sobre o quadro teórico geral e sobre os conhecimentos didáticos já adquiridos sobre o assunto em questão.

- Segunda Fase: concepção e análise a priori. Esta fase comporta uma parte de descrição e outra de previsão. 0 professor/pesquisador elabora a proposta de ensino baseado nas informações colhidas na primeira fase, faz previsões das dificuldades que poderão surgir nas aulas, como também prevê o que se pretende ensinar em cada etapa de sequência de ensino.

- Terceira Fase: experimentação. A fase da experimentação é clássica. É a fase da realização da engenharia com uma certa população de alunos. Ela se inicia no momento em que se dá o contato pesquisador/professor com a população de alunos objeto da investigação.

- Quarta Fase: análise a posteriori e validação. Essa fase se apoia sobre todos os dados colhidos durante a experimentação constante das observações realizadas durante cada sessão de ensino, bem como das produções dos alunos em classe ou fora dela. É da confrontação das análises a priori e a posteriori que se validam ou se refutam as hipóteses levantadas no início da engenharia.

Considerando as representações sugeridas pelas Orientações Curriculares para o Ensino Médio fomos levados à Teoria dos Registros de Representações Semióticas, de acordo com esta Teoria a comunicação em Matemática se estabelece por meio de suas representações. 0 aluno deve conhecer representações de um objeto dado, saber fazer tratamentos em cada uma delas e, além disso, deve saber mudar de uma representação para outra (Duval, 2003). Este autor considera que são três as atividades cognitivas fundamentais de representação ligadas à semiósis: formação, tratamento e conversão, (Duval, 2009, p.54). Na figura 2 temos um exemplo de uma atividade de tratamento e de uma de conversão. 
Figura 2. Tratamento e conversão

Tratamento

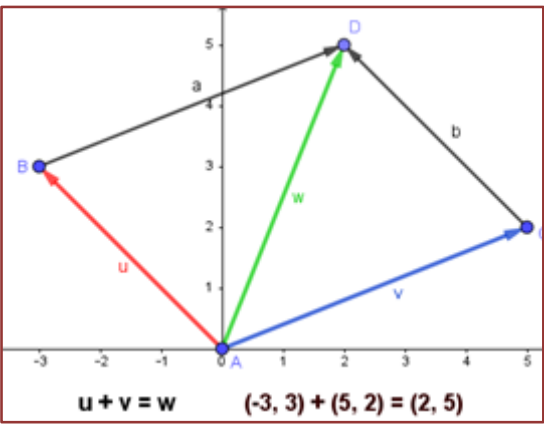

Conversão

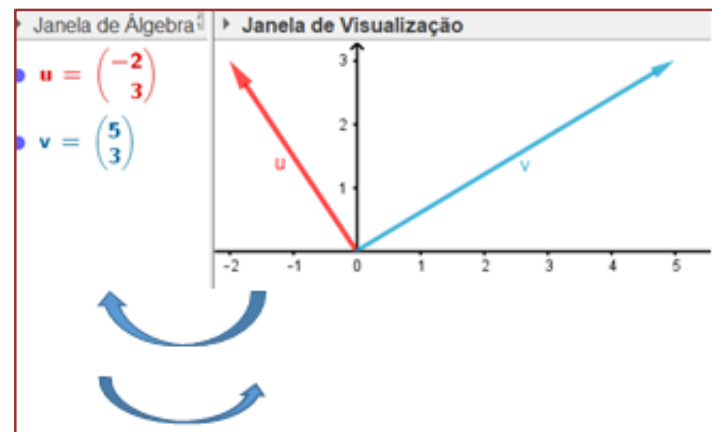

Fonte: Elaborada pelo autor.

Os softwares encontram-se cada vez mais presentes em nosso cotidiano. Pesquisadores em Educação Matemática, como Souza(2010) e Alves(2012), propõem sequências de ensino para conteúdos de matemática amparados pela tecnologia. Um dos softwares bastante utilizados por professores/pesquisadores desta área é o Geogebra, gratuito e que permite uma visualização dos objetos matemáticos em mais de uma representação, incluídas as tradicionais geométrica e algébrica. Para Alves (2012, p.322) a tecnologia e, notadamente, o software Geogebra, pode proporcionar o entendimento e a descrição geométrica-dinâmica de definições e teoremas.

\section{RESULTADOS E DISCUSSÃO}

Analisando uma questão do teste diagnóstico: Seja $u=(5,4)$ e $w=(1,3)$. Determine as coordenadas do vetor $\mathrm{u}$, tal que: (a) $\mathrm{u}=\mathrm{v}+\mathrm{w}$; (b) $\mathrm{u}=\mathrm{v}-\mathrm{w}$; $\mathrm{u}=2 \mathrm{v}-3 \mathrm{w}$. Percebeu-se que há dois registros de partida: o das representações numéricas e o das representações vetoriais, e um de chegada: o registro das representações numéricas. Os vetores $v$ e $w$ foram representados nos registros das representações numéricas, e o vetor $u$ no registro da representação vetorial. A solução deveria ser apresentada no registro das representações numéricas.

A atividade (Conceito de vetor) pode ser consultada em Lucas (2017), e foi elaborada para ser desenvolvida com o auxílio do Geogebra, pois este permite a exploração de ao menos duas representações dos vetores. Trabalha-se o conceito de vetor a partir da ideia de segmento orientado.

Fazendo uso dos recursos do Geogebra, o aluno visualizou diversos representantes de um vetor em duas de suas representações, algébrica e geométrica. Após a realização dessa atividade, esperava-se que o aluno tivesse compreendido o significado das representações de um vetor, vetores iguais e vetores paralelos e fosse capaz de fazer conversão entre estas duas formas de representar este objeto matemático.

\section{CONSIDERAÇÕES FINAIS}

A partir de estudo bibliográfico, identificou-se elementos que dificultam o ensino-aprendizagem de vetores no Ensino Médio. Para amenizar tais dificuldades, percebeu-se que a abordagem didática pode ser de fundamental importância. Assim, foi construída uma Sequência Didática, fundamentada na Engenharia Didática, na Teoria das Representações Semióticas e utilizando o Geogebra para potencializar a exploração dessas representações, mostrando uma possibilidade de abordagem para o ensino de vetores.

Acreditamos que a partir desta SD estamos contribuindo com as pesquisas em Educação Matemática. Outras SD semelhantes relacionadas a esse mesmo objeto matemático poderão ser elaboradas, por exemplo para abordar o conceito conversão, adição, multiplicação de vetor por um número real, entre outros.

\section{REFERÊNCIAS}

[1] Alves, F. R. V. Interpretação geométrica de definições e teoremas: o caso da análise real. In: Conferência Latinoamericana de Geogebra. Montevidéu, 322-329. Disponível em:

[2] http://www.geogebra.org.uy/2012/home.php. Acessado em: 02 set. 2019.

[3] Alves, F. R. V (2016). Engenharia Didática para a generalização da sequência de Fibonacci: uma experiência num curso de licenciatura. Educ. Matem. Pesq., São Paulo, v.18, n.1, p.61-93. 
[4] Bittar, M. O ensino de vetores e o registro de representação semiótica. In: Machado, S.D.A (org). Aprendizagem em Matemática: Registro de representação semiótica. Campinas, SP: Papirus, p. 71-94, 2003.

[5] Brasil, MEC, SEB. Orientações Curriculares para o Ensino Médio. Ciências da Natureza, Matemática e suas Tecnologias. Brasília: 2006.

[6] Castro, R. M. P. Introdução do estudo de vetores no ensino médio: Um ganho significativo para o estudo da Geometria Analítica. 2014. Dissertação(Mestrado em Matemática) - Universidade Federal do Ceará, Fortaleza.

[7] DAMM, R.F. Registros de Representação semiótica e funcionamento cognitivo da compreensão em Matemática. In: Machado, S.D.A (org). Educação matemática: Uma (nova) introdução: 2ª ed. 2ª reimp - São Paulo: EDUC, 2012 p. 167-188.

[8] Duval, R. Registro de Representação Semiótica e funcionamento cognitivo da compreensão em Matemática. In: Machado, S.D.A (org). Aprendizagem em Matemática: Registro de representação semiótica. Campinas, SP: Papirus, p. 11-33, 2003.

[9] Duval, R. Semiósis e Pensamento Humano: registros semióticos e aprendizagem intelectuais. Coleção contexto da ciência. São Paulo: Livraria da Física, 2009.

[10] Lucas, C. M. N. Elaboração de uma sequência de Ensino de Vetores por meio da Sequência Fedathi e exploração de suas representações com uso do Geogebra. 2017. Dissertação (Mestrado em Matemática) Universidade Federal do Piauí, Parnaíba.

[11] Machado, S.D.A. Engenharia Didática. In: Machado, S.D.A. (org). Educação Matemática. Uma (nova) introdução. 3aㅡ ed. revis, 2ª reimp - São Paulo: EDUC, 2012 p. 233-247.

[12] Martins, R. L. 0 ensino de vetores e a interdisciplinaridade. 2015. Dissertação (Mestrado em Matemática) Universidade Estadual da Paraíba, Campina Grande.

[13] Souza, M.J.A. Aplicações da Sequência Fedathi no ensino e aprendizagem da Geometria mediado por tecnologias digitais. 2010. 230f. Tese(Doutorado) - FACED - Universidade Federal do Ceará, Fortaleza - CE. 


\section{Capítulo 8}

As práticas metodológicas inovadoras no ensino da matemática das Escolas Municipais da Cidade de Água Branca-PI

\section{Azenate Pereira de Sousa \\ Edimar Campelo Araujo \\ Osiel Cesar da Trindade Júnior}

Resumo: Aprender Matemática é uma questão bem mais ampla do que apenas compreender conceitos básicos de adição, subtração, multiplicação e divisão. Para tanto, esse saber é, sobretudo, muito relevante ao desenvolvimento do conhecimento lógico presente nas diversas situações da vida cotidiana. Assim, o ensino na educação Matemática releva-se numa prática educativa que depende da interatividade dos alunos com os conteúdos e faz requerer do professor metodologias adequadas na condução desse conhecimento. Desse modo, este artigo tem como objetivo geral analisar as metodologias inovadoras praticadas no ensino da Matemática a partir de um estudo realizado nas escolas municipais da cidade de Água Branca-PI. Por isso, com base nessa abordagem efetuou-se um estudo quanti-qualitativo, bibliográfico e de campo com amostragem de dados de um questionário aplicado a 14 professores de Matemática dessas escolas para a fundamentação de uma análise crítico-reflexiva sobre a metodologia de ensino nessa disciplina. Diante disso, a pesquisa obteve como resultado uma compreensão de que a percepção dos professores de Matemática referente ao processo metodológico tem valor significativo na melhoria da aprendizagem dos alunos e se faz ressaltar num aspecto positivo para a qualidade do ensino dessa disciplina.

Palavras-chave: Ensino. Metodologia. Matemática. 


\section{INTRODUÇÃO}

0 prospecto atual da educação escolar brasileira tem presenciado crescentes discussões acerca de inovações quanto ao trabalho pedagógico na sala de aula como também na renovação dos métodos de ensino. Nesse cenário, o constante desenvolvimento desses elementos assume uma importância substancial na consolidação da aprendizagem dos alunos. A partir disso, muito se tem discutido sobre a aprendizagem escolar e quando se trata da aprendizagem na Matemática são constantes as pesquisas educacionais que com frequência abordam a questão da qualidade no processo metodológico de ensino nessa disciplina.

Sobre isso, observa-se que entre as muitas vertentes que questionam as formas de ensinar Matemática nas escolas geralmente defendem uma nova proposta de ensino para tornar significativa a aprendizagem dos alunos. Em tese, argumentam que a Matemática como um componente curricular tem relevância na estruturação cognitiva do aluno e, portanto precisa ser um conhecimento articulado com a aplicação na vida diária, pois os princípios e conceitos básicos dessa disciplina vão permitir ao aluno aflorar os níveis intelectuais necessários ao seu pleno desenvolvimento e total aprendizagem.

Para tanto, como se observou nos discursos de diversos teóricos considerados na pesquisa, numa realidade educacional podem existir múltiplos fatores ocasionais que diretamente interferem no processo educativo e terminam por prejudicar a qualidade do ensino e aprendizagem dos alunos. Por sua vez, nessa constatação também está à questão da condução dessa disciplina na sala de aula o que se permite então apurar neste estudo as fragilidades existentes nesse processo. Sendo assim, tem o professor diante de si o desafio de educar e lidar com as dificuldades a sua volta ao mesmo tempo em que deve renovar seus métodos e adquirir novas habilidades com competências educacionais.

Assim, por se tratar a temática deste estudo uma questão metodológica e didática do professor o objetivo geral foi analisar as metodologias inovadoras praticadas no ensino da Matemática com base num estudo em escolas do município de Água Branca-PI. Por conseguinte, também tratou de caracterizar algumas práticas dos professores de Matemática nessas escolas. Ademais, também identificou as principais dificuldades no processo de ensino-aprendizagem, assim como discutiu o assunto da contextualização do conhecimento matemático na educação escolar.

Nesse sentido, a pesquisa tem por base teórica autores como Carvalho (1994) que afirma que o ensino de Matemática requer a princípio uma desconstrução do mito dessa disciplina ser apresentada como um saber unicamente individual, vazio e acabado. Para Bitencourt (2010) tão necessária é a compreensão dessa ciência que contribui em diversas representações práticas do cotidiano social. Assim, segundo Pais (2006) o ensino da Matemática na escola deverá nortear a compreensão de uma aprendizagem interdisciplinar que condicione o aluno a interpretar conceitos e a utilizá-los na diversidade social que se encontra ao seu redor.

Vale ressaltar, que o estudo também se fundamentou nos conceitos sobre prática educativa conforme orienta o texto dos Parâmetros Curriculares Nacionais - PCNs da disciplina de Matemática do Ensino Fundamental (BRASIL, 2000). Por meio disso, a busca em outros trabalhos científicos voltados para a educação Matemática serviu para a comparação de ideias e trouxe enriquecimento à pesquisa com a finalidade de "nortear os caminhos apontados para o ensino da matemática e, assim, poder contrastá-los com a prática adotada pelos professores." (NORONHA, 2013, p.9).

\section{METODOLOGIA}

Os procedimentos metodológicos realizados nas pesquisas científicas geralmente obedecem a métodos e técnicas de elaboração própria. Desse modo, segundo Gil (2010) o processo deve, portanto identificar a natureza do método, justificar sua realização, caracterizar os elementos, especificar os instrumentos de coleta de informações e descrever os passos da análise de dados para aprofundamento do conhecimento na realidade observada. Assim, a apresentação dos meios, sobretudo deve ser adequada ao desenvolvimento do trabalho como também deve ser escolhida de forma a melhor possibilitar a descrição do estudo a ser caracterizado. (SANTOS, 2013).

Conforme isso, das concepções apontadas admite-se que este estudo apresenta um processo metodológico que se define por ser uma ação racional e sistemática de investigação reflexiva com a finalidade de levantar dados para propor uma discussão a respeito das metodologias inovadoras no ensino da Matemática, pois se trata de ser a pesquisa científica "um procedimento formal, com método de 
pensamento reflexivo que requer um tratamento científico e se constitui no caminho para conhecer a realidade ou para descobrir verdades parciais." (LAKATOS, 2003, p.155).

\subsection{CENÁRIO DA PESQUISA}

Segundo a proposta desse estudo a pesquisa de campo se realizou nas seis escolas municipais da cidade de Água Branca - PI, que ofertam o Ensino Fundamental menor e maior, com o objetivo de recolher as informações necessárias sobre o assunto. Por meio disso, observou-se que cada escola possui prédio próprio e a estrutura organizacional das mesmas oferece um ambiente propício à educação das crianças. Assim, essa opção de fazer a pesquisa de campo em todas as escolas foi definida pelo fato de ser relevante para este estudo obter uma quantidade de dados mais significativos no universo pesquisado e assim conseguir na análise desses dados uma visão mais ampla da situação investigada.

\subsection{NATUREZA DA PESQUISA}

A pesquisa trata-se de um estudo quanti-qualitativo com proveniência bibliográfica que mediante um estudo de campo situou-se na perspectiva de analisar as considerações teóricas referentes às metodologias inovadoras praticadas no ensino da Matemática. Conforme isso, o desenvolvimento processa-se numa abordagem científica onde os aspectos qualitativos e quantitativos consistiram em traduzira uma análise interpretativa das informações obtidas. (ABREU, 2011).

Diante disso, para o trabalho ter um caráter científico no plano desta elaboração o texto fundamentou-se em fontes que serviram para fundamentar a temática. Por isso, por ser bibliográfica e com respaldo a intervenção direta junto aos professores de Matemática das escolas municipais, a fundamentação em estudos sobre o assunto e a coleta de dados contribuíram para averiguar como estão sendo praticadas as metodologias inovadoras no ensino da Matemática. (ANDRADE, 2003).

\subsection{ELEMENTOS DA PESQUISA}

Feita a apresentação da proposta do estudo à direção das instituições de ensino, em cada escola foi distribuído aos sujeitos da pesquisa um questionário com seis perguntas tanto abertas como fechadas para análise contextual sobre os dados a serem colhidos. Dessa maneira, como planejado o projeto da pesquisa tinha como alvo os professores de Matemática do ensino fundamental de 1ㅇa ao ano de cada escola, no entanto, o estudo deparou-se com a realidade de encontrar situações adversas em algumas das escolas. Por causa disso, ocorreu que do universo de professores localizados apenas 14 responderam às seis perguntas do questionário.

\subsection{INSTRUMENTOS DA PESQUISA}

Para reunir o conjunto de dados relevante ao estudo o instrumento utilizado foi um questionário com seis perguntas abertas e fechadas panejado em função dos objetivos da pesquisa para que junto às respostas dos professores de Matemática se desenvolvesse a análise da pesquisa. Desse modo, essa finalidade indispensável do questionário, sobretudo garantiu ao estudo colher e organizar as respostas a serem desenvolvidas de acordo com os objetivos do trabalho. (SANTOS, 2007).

Contudo, a impossibilidade de se alcançar todos os elementos do universo escolhido tornou a seleção dos dados numa amostragem, entretanto, nem por isso se deixou de apresentar um resultado preciso. Assim, mediante as respostas reunidas das amostras permitiu-se reunir informações concretas e asseguradas em garantir a fidelidade científica na interpretação dos discursos analisados. (SANTOS, 2013).

\section{RESUSTADOS E DISCUSSÕES}

Como proposta apresentada, o estudo analisou os dados coletados do questionário e a partir das tabulações representativas de cada resposta buscou-se fundamentar as interpretações de cada informação e o posicionamento de cada opinião expressada devidamente contextualizada nos teóricos. Assim, a princípio diante da análise das informações reunidas dos sujeitos da pesquisa foram identificados os seguintes aspectos demostrados na Tabela 1. 
Tabela1 - Representação geral quanto aos professores no estudo realizado.

\begin{tabular}{|l|c|c|}
\multicolumn{1}{|c|}{ Categorias } & Quantidade & Total em porcentagem \\
\hline Participantes & 14 & $63,6 \%$ \\
\hline Desistentes & 8 & $36,4 \%$ \\
\hline Formação em Matemática & 7 & $50 \%$ \\
\hline Formação em Pedagogia & 5 & $35,7 \%$ \\
\hline Formação em outra licenciatura & 2 & $14,3 \%$ \\
\hline
\end{tabular}

Fonte: Pesquisa direta, 2015.

Conforme descrito na tabela, o percentual de $63,6 \%$ corresponde ao número de sujeitos que contribuíram com a sua participação voluntária na pesquisa, em contrapartida obteve-se um percentual de $36,4 \%$ desistentes. Também foi possível verificar que $50 \%$ dos sujeitos tem formação em Matemática, $35,7 \%$ em Pedagogia e 14,3\% possuem formação em outra licenciatura. Nesse aspecto, a análise geral do universo da amostragem constatou que $85,7 \%$ dos sujeitos possuem a formação adequada e específica para atuar como professores da disciplina no Ensino Fundamental. Logo, essa demonstração permitiu então visualizar o percentual calculado da quantidade de participantes e claramente informar a qualificação dos sujeitos apresentados.

No que se refere ao estudo, no questionário aplicado primeiro perguntou-se aos sujeitos se o planejamento de um novo método para o ensino da Matemática ajudaria a criança na sua aprendizagem, como resposta $100 \%$ dos entrevistados afirmaram que sim. Diante disso, esse consenso permitiu compreender que a utilização de novos métodos no processo didático tornará possível facilitar a aprendizagem do aluno. Assim, essa constatação vem confirmar que de fato o professor precisa zelar pelo aprendizado de seus alunos com a utilização de novas técnicas e numa perspectiva construtivista sempre que for necessário melhorar a sua prática de ensino. (PAIS, 2006).

A respeito disso, Bitencourt diz que:

O professor é um tipo de profissional que necessita ser autônomo no seu aperfeiçoamento, pois está em constante contado com diferentes exigências advindas do contexto social, político, acadêmico, escolar. Enfim é um profissional que deve está preparado para a qualificação contínua e progressiva, pois tem que ser, na complexidade do sistema educacional que está inserido, responsável pela identificação dos saberes a serem construídos. Assim, esse professor buscará por meio do desenvolvimento profissional, aperfeiçoar-se na sua ação docente. (2010, p.35)

Diante dessa concepção, como afirma o texto é função do professor buscar qualificar-se diante da necessidade do seu meio e compreender que sua prática tem como principal objetivo a aprendizagem dos alunos em todos os sentidos possíveis. Isto porque, o professor exerce um papel ativo com saberes específicos de sua formação, assim se souber direcionar valores aos planejamentos dos métodos estará apto a prover os cenários ideais de aprendizagem de modo a construir um novo pensamento e de uma forma gradativa constituir a base da sua ação pedagógica. (PAIS, 2006).

Conforme isso, segundo Noronha (2013), a exigência atual é que professor de Matemática então estabeleça uma nova abordagem dos métodos e a partir da assimilação de um novo conceito de prática pedagógica então venha a planejar melhor a sua didática. Daí nota-se que essa reflexão traz intrínseca a questão do reavaliar a participação do professor de Matemática na aprendizagem do aluno. Assim, o professor deve ser um agente facilitador durante a aula, por isso fundamental é que seja um profissional que esteja em constante aprendizado. (D’AMBROSIO, 1996).

Em razão disso, a ideia de priorizar a formação integral do aluno traz ao professor de Matemática possibilidades de investir num novo sistema de ensino e com essa ênfase voltar-se para a dimensão subjetiva do novo conceito de ensinar, assim como afirmou Freire (1996) o ensinar não é mais você simplesmente repassar informações como quem entrega um manual de instruções, isso envolve mais comprometimento com a causa, ou seja, é fazer acontecer situações em que o aluno todos os dias seja desafiado a confrontar os fatos e formar seu conhecimento. 
Em outro aspecto, nota-se que no meio dessas mudanças a formação didática do professor de Matemática consequentemente tem demandado novas propostas de formação docente. Quanto a isso, a respeito das novas metodologias de ensino na Matemática contribuir na formação de um novo professor, os sujeitos responderam conforme mostra a Tabela 2.

Tabela 2 - Quanto às novas metodologias no ensino da Matemática contribuir na formação de um novo professor.

\begin{tabular}{|c|c|c|}
\hline Respostas & Frequência & Porcentagem \\
\hline Sim & 13 & 92,8 \\
\hline Não & 1 & 7,2 \\
\hline Muito pouco & - & - \\
\hline Total & 14 & 100 \\
\hline
\end{tabular}

Fonte: Pesquisa direta, 2015.

Através desses dados descritos na tabela acima se verifica que, 92,8\% acreditam que essa contribuição é relevante na formação de um novo professor de Matemática, enquanto isso o percentual de 7,2\% diz não concordar com essa afirmativa. Acerca disso, Candau (2013) destaca ser a pesquisa em estudos didáticos o caminho da construção social de um novo professor. Sobre esse aspecto, Freire (1996) já ponderou que só é possível o ensino através da pesquisa. Do mesmo modo, Bitencourt (2010) comenta que isso implica afirmar que as mudanças sempre sobrevêm às pesquisas.

Assim, nessa relação D’Ambrosio destaca que:

A prática resultante da pesquisa modificará ou aprimorará a teoria de partida. E assim modificada ou aprimorada essa teoria criará necessidade e dará condições de mais pesquisa, com maiores detalhes e profundidade, oque influenciará a teoria e a prática. Nenhuma teoria é final, assim como nenhuma prática e definitiva, e não há teoria e prática desvinculadas. (1996, p.81)

Nesse sentido, declara-se ser a pesquisa a peça fundamental para a produção de um novo conhecimento. Isto significa, que toda pesquisa serve para modificar conceitos e então formar novas teorias, logo a confirmação desse fato conduz à lógica do aperfeiçoamento do professor de Matemática. Dessa maneira, as novas metodologias apresentarão ao novo professor um modelo didático funcional que torne o conhecimento matemático uma ação dinâmica do aluno com os conteúdos ao mesmo tempo em que o motivará a participar ativamente no processo de ensino. (CARVALHO, 1994).

Ao considerar isso, o professor de Matemática precisa ter conhecimento de que a aprendizagem significativa do aluno não irá depender apenas da sua habilidade técnica de conduzir os assuntos, nesse processo será essencial que sua prática também envolva componentes facilitadores da aprendizagem. Em vista disso, quanto à questão das práticas lúdicas contribuírem para o ensino e aprendizagem da Matemática apresentam-se os resultados na Tabela 3.

Tabela 3 - Quanto às práticas lúdicas terem contribuído para o ensino e aprendizagem da Matemática.

\begin{tabular}{|c|c|c|}
\hline Respostas & Frequência & Porcentagem \\
\hline Sim & 13 & 92,8 \\
\hline Não & 1 & 7,2 \\
\hline Muito pouco & - & - \\
\hline Total & 14 & 100 \\
\hline
\end{tabular}


De acordo com a tabela para $92,8 \%$ dos sujeitos as práticas lúdicas têm favorecido a qualidade na aprendizagem do conhecimento matemático, em contrapartida 7,2\% não considerou essa prática ter relevância significativa nesse processo. Sobre essa posição analisa-se que, embora a atitude da maioria dos sujeitos seja positiva quanto ao desenvolvimento de práticas lúdicas no ensino da Matemática ainda existe muita resistência quanto à utilização desse método durante a aula. Isto porque "as abordagens lúdicas ainda desconcentram muitos profissionais, que não sabem bem como apoiar dessa maneira a aprendizagem e o desenvolvimento das crianças." (MOYLES, 2010, p.13).

Sobre isso, segundo Tocantins (2007), como proposta de ensino a Ludicidade tem sido uma área em que muito se exige uma compreensão bem ampla de sua dimensão pedagógica. Por isso, quando se trata de prática lúdica na aprendizagem Matemática a dimensão disso é dar lugar ao novo e trabalhar com atividades de jogos em cima das necessidades dos alunos, ou seja, a utilização de qualquer jogo incita à atividade cognitiva, gera significados e estrutura o raciocínio lógico. (BRASIL, 2000).

Para tanto, os jogos matemáticos requerem do professor um planejamento adequado cujos objetivos precisam ser condicionados aos conteúdos. Por vezes, essa questão dificulta a utilização do método, pois nem sempre a formação acadêmica do professor comtemplou o lúdico como elemento curricular que forneceria ao docente o alicerce de uma capacidade intelectual em conduzir o método no universo dos conteúdos escolares. Assim, o professor de Matemática que ao usar os jogos para ensinar ganhará qualidade no seu ensino e aprenderá a inovar a sua prática todo dia. (SANTOS, 2011).

Portanto, afirma-se que a formação docente num aspecto lúdico só reforça a ideia de que a aprendizagem Matemática numa abordagem lúdica pose ser adquirida de forma prazerosa e apesar de ser a Ludicidade uma característica da Educação Infantil nada impede a aplicação de jogos nos demais níveis da Educação Básica. Desse modo, "a prática docente é reflexo da formação do indivíduo. Por isso quanto mais vivências lúdicas forem proporcionadas nos currículos acadêmicos, mais preparado o educador estará para trabalhar com a criança." (SANTOS, 2011, p.12).

Nessa concepção apontada, fundamental também é que todo professor de Matemática reveja sua postura e procure eliminar as constantes dificuldades dos alunos durante a aula. Dessa maneira, ao tratar sobre essas dificuldades na aprendizagem Matemática serem na maioria dos casos consequências da metodologia de ensino do professor têm-se as seguintes informações registradas na Tabela 4.

Tabela 4 - Quanto às dificuldades de aprendizagem na Matemática ser na maioria consequências da metodologia de ensino do professor.

\begin{tabular}{|c|c|c|}
\hline Respostas & Frequência & Porcentagem \\
\hline Sim & 3 & 21,5 \\
\hline Não & 7 & 50 \\
\hline Muito pouco & 4 & 28,5 \\
\hline Total & 14 & 100 \\
\hline
\end{tabular}

Fonte: Pesquisa direta, 2015.

Conforme a descrição dos dados registrou-se que 21,5\% concordaram que na maioria das vezes são consequências do método de ensino do professor. No entanto, $50 \%$ disseram que não e 28,5\% afirmaram ser muito pouco. Diante disso, ao analisar essa questão primeiro enfatiza-se que diversos são os fatores que interferem no processo de aprendizagem da Matemática como em qualquer outra disciplina. Contudo para este estudo foi mais relevante considerar a ação do professor cuja "competência requerida é de ordem didática, epistemológica, relacional." (PERRENOUD, 2000, p.69).

Segundo Bitencourt analisa-se que:

Parte dos problemas apresentados que se referem ao ensino da matemática está relacionada à formação do professor. 0 desenvolvimento de uma prática de ensino da matemática depende de uma ação pedagógica que vise ao aprimoramento da ação educativa exercida no sistema educacional, no trabalho em sala de aula. Essa ação é caracterizada como a relação entre teoria e prática em que a formação 
profissional qualificada oportunizará que o professor desenvolva estratégias para atingir um determinado fim - ser um educado matemático. (2010, p. 22).

Conforme isso se reconhece aí que a formação do professor de Matemática é um aspecto de grande relevância para a qualidade do ensino e aprendizagem do aluno. Por tais razões, afirma-se que no mínimo o professor de Matemática necessita ter base para dominar a disciplina. Por vezes, o ideal seria o professor ter habilidade didática para desenvolver todos os assuntos e saber utiliza-las a qualquer tempo, sobretudo sem desconsiderar o conhecimento do aluno e o universo por ele compartilhado. (D’AMBROSIO, 1996).

Para isso, essa lógica baseia-se no fato de que em muitas das vezes o professor só utiliza o livro didático para dar aula o que torna insatisfatório o desempenho na aprendizagem Matemática, assim se torna inaceitável permitir que o professor conduza um ensino com primazia na reprodução e acúmulo de informações totalmente desarticuladas de um contexto. Dessa maneira, aprende-se que ensinar Matemática é ir mais além do que a representação teórica dos seus conteúdos. (BRASIL, 2000).

Não obstante, observa-se que a realidade atual não tem garantido a superação de práticas tradicionais. Diante disso, aponta-se que nessa visão é imposta ao aluno uma condição de passividade que diante da autoridade docente apenas reproduz os conteúdos sem nenhum sentido lógico. Sobre isso, percebe-se que hoje a educação Matemática contempla inúmeras concepções de ensino, então se o professor utilizar esses novos meios, isso significa que ele irá mais longe para alcançar resultados positivos. (CARVALHO, 1994).

No entanto, vale lembrar que o curioso é notar que muitos professores de Matemática, muitas das vezes, compreendem que a mudança esteja na reorganização de ambientes físicos com salas estruturadas que nada lembram a visão tradicionalista. Nesse sentido, essa concepção errônea de mudança pedagógica transparece que a solução estaria apenas em modificar o ambiente. Contudo, isso se trata de um conjunto de aspectos que inclui a formação técnica do professor e a formação própria do seu eu. (D’AMBROSIO, 1996).

Ou seja, questiona-se uma educação Matemática que incorpore novos procedimentos para melhorar a atividade docente. Para isso, a construção de uma prática que inove o ensino da Matemática não dependerá de uma visão unilinear, nem tampouco se conseguirá classificar um único método como resposta. Isto é, não será a prática do professor sozinha que irá tornar melhor a aprendizagem mais sim a reconstrução do sistema educativo a cada dia. Por isso, considera-se que o professor deve aplicar o conhecimento matemático mediante práticas ligadas tanto à compreensão da teoria como na construção de significados na prática (BRASIL, 2000).

Referente a isso, tem-se que o trabalho educativo na Matemática não deve estar desarticulado das situações do convívio social. Por essa razão, cumpre esclarecer que a Matemática é uma ciência de linguagem abstrata e que para se desenvolver necessita de conexões integradas ao mundo real da vida prática, "é por este motivo que, mais que nenhuma outra ciência, seu ensino deve ser contextualizado." (DUHALDE, 1998, p.34).

Quanto a isso, confirma-se hoje que a relação dos conteúdos da Matemática com os aspectos do cotidiano do aluno promovem a construção da aprendizagem significativa. Assim, ao se questionar sobre a contextualização no ensino da Matemática garantir uma aprendizagem mais significativa 100\% dos sujeitos concordaram em afirmar que essa forma é a melhor maneira de trabalhar a Matemática na sala de aula.

De todo modo sabe-se que:

A expansão do raciocínio e outras competências associadas são aplicáveis em diversas situações do cotidiano, tais como o desenvolvimento da escrita e da leitura, além de contribuir na formalização do saber escolar e abrir novos horizontes de compreensão das ciências e do mundo no qual o educando está inserido. (PAIS, 2006, p.23)

Como no discurso, observa-se que essa postura procura determinar a relação do contexto social com a aprendizagem escolar. Em tese, a articulação das disciplinares escolares com o cotidiano resulta numa construção de significados para o aluno. Nessa circunstância, a Matemática então não deve ser mais compreendida como um saber imutável, fechado e obsoleto, do mesmo modo o professor não pode deixar de estruturar a formação do pensamento lógico do seu aluno. Assim, entre outros aspectos relevantes na aprendizagem Matemática o meio social tão complexo precisa ser uma área de intenso aprofundamento 
matemático, principalmente quanto à aplicabilidade dos conceitos na resolução de situações problemas. (BRASIL, 2000).

No entanto, como cita Bitencourt (2010) para os professores a questão da contextualização da Matemática no convívio social ainda apresenta muitos impasses, uma vez que a formação acadêmica do docente nem sempre irá qualificar o seu fazer pedagógico. Diante disso, Goulart (1995) enfatiza que o problema estaria no modelo multidisciplinar que fraciona as matérias e inviabiliza a compreensão da "integração do conhecimento num todo harmônico e significativo." (p.95).

Assim, afirma que:

Se quisermos avançar para um currículo interdisciplinar, temos que pensar interdisciplinarmente, isto é, ver o todo não pela simples somatória das partes que o compõem, mas pela percepção de que tudo sempre está em tudo, tudo repercute em tudo, permitindo que o pensamento ocorra com base no diálogo entre as diversas áreas do saber. (GOULART, 1995, p. 97).

Nesse aspecto, essa concepção de interdependência das disciplinas permite indagar a posição da escola e do professor que juntos devem priorizar uma aprendizagem significativa na medida em que garanta ao aluno uma visão completa de informações contextualizadas entre si e também com o meio social. Por isso, a valorização dos conhecimentos empíricos que o aluno traz para a sala de aula tem extrema contribuição, pois eles já construíram suas relações, então o professor pode aproveitar essa situação para desconstruir e reconstruir esse conhecimento. (TOLCHINSK, 2004).

Por tais razões, entende-se que o processo de ensino e aprendizagem seja antes de tudo uma relação de reciprocidade entre o professor e o aluno onde se prevaleça o pleno desenvolvimento do saber. Por conseguinte, visualizar a contribuição do ensino de Matemática na educação escolar tem confirmado a continuidade gradual da aprendizagem lógica e dedutiva dos alunos na vida escolar. Sobre isso, quanto à deficiência da aprendizagem Matemática prejudicar o desenvolvimento cognitivo da criança nas demais disciplinas registrou-se conforme os resultados os seguintes dados na Tabela 5.

Tabela 5 - Quanto à deficiência da aprendizagem na Matemática comprometer o desenvolvimento cognitivo da criança nas demais disciplinas.

\begin{tabular}{|c|c|c|}
\hline Respostas & Frequência & Porcentagem \\
\hline Sim & 7 & 50 \\
\hline Não & 6 & 42,8 \\
\hline Muito pouco & 1 & 7,2 \\
\hline Total & 14 & 100 \\
\hline
\end{tabular}

Fonte: Pesquisa direta, 2015.

Conforme apresentado na tabela acima se observou que $50 \%$ dos sujeitos afirmaram que o aprendizado em outras disciplinas fica prejudicado, 42,8\% disseram não, enquanto que 7,2\% muito pouco. Diante disso, segundo Pais (2006) sabe-se que a Matemática é importante para o desenvolvimento da capacidade cognitivo lógico do aluno. No entanto, o autor deixa bem claro que não se pode especificar uma determinação da Matemática entre as demais disciplinas escolares, pois "todas visam o desenvolvimento do aluno ao mesmo tempo em que apresentam sua especificidade no que se refere ao tipo de raciocínio predominante em sua lógica estrutural." (PAIS, 2006, p.23).

Dessa maneira, como já tido o conveniente seria então que o professor de Matemática reproduzisse um ensino interdisciplinar com atividades educativas que desenvolva várias competências e possibilite ao aluno o favorecimento de sua capacidade intelectual. Para isso, o ensino da Matemática deve desmistificar o pressuposto da neutralidade dando-se a abertura ao novo e por meio disso complementar em outros saberes a reelaboração de significados e conceitos elementares para a efetivação da aprendizagem escolar. (MACHADO, 1994).

Para tanto, vale justificar que: 
O ensino de Matemática prestará sua contribuição à medida que forem exploradas metodologias que priorizem a criação de estratégias, a comprovação, a justificativa, a argumentação, o espírito crítico, e favoreçam a criatividade, o trabalho coletivo, a iniciativa pessoal e a autonomia. (BRASIL, 2000, p.31).

Assim, conforme o texto pressupõe-se que diante de uma nova abordagem no ensino da Matemática será possível pensar um processo educativo que efetive a concepção do conceito de aprendizagem significativa numa extensão imensurável à atuação docente. Desse modo, espera-se que na percepção dos professores quantos aos métodos se estabeleça a essência da prática educativa rumo à superação das falhas e ressignificação do papel da educação na sociedade.

\section{CONSIDERAÇÕES FINAIS}

O estudo realizado permitiu analisar as metodologias inovadoras no ensino da Matemática, para isso, considerou-se caracterizar as práticas de ensino dos professores e identificar quais dificuldades são encontradas durante esse processo. Assim, desenvolveu-se a compreensão reflexiva de que o professor ao analisar a sua prática deve conduzir a aprendizagem do aluno de forma dinâmica e contextualizada aos conceitos práticos do dia a dia.

Desse modo, cumpre destacar que nem sempre a realidade é condizente com o discurso e apesar das contradições observadas durante a pesquisa de campo o resultado da análise dos dados foi positivo quanto à concepção do docente. Assim, ao compreender que aprendizagem seja o produto final do processo de ensino cabe ao professor assumir o compromisso de inovar sua didática mediante a necessidade educacional do seu alunado de maneira a superar as dificuldades que surgirem durante o processo.

\section{REFERÊNCIAS}

[1] ABREU, J. J. V. de. Os caminhos da pesquisa científica: fundamentação, produção e difusão do conhecimento. Teresina: UAB/UESP, 2011.

[2] ANDRADE, M. M. de. Introdução à metodologia do trabalho científico: elaboração de trabalhos na graduação. 6. ed.- São Paulo: Atlas, 2003.

[3] BITENCOURT, K. F. Educação matemática por projetos na escola: prática pedagógica e formação de professores. - Curitiba: Certa Editorial, 2010.

[4] BRASIL. Secretaria de Educação Fundamental. Parâmetros Curriculares nacionais: matemática. - 2. ed. Rio de Janeiro: DP\&A, 2000.

[5] CARVALHO, D. L. de. Metodologia do ensino da matemática. -2. ed. rev. - São Paulo: Cortez, 1994.

[6] CANDAU, V.M. Rumo a uma nova didática. - 23. ed. - Petrópolis, RJ: Vocez, 2013.

[7] D’AMBROSIO, Ubiratan. Educação matemática: da teoria à prática. - Campinas, SP: Papirus, 1996.

[8] DUHALDE, M. E. Encontros iniciais com a Matemática: contribuições à educação infantil. Porto Alegre: Artes Médicas, 1998.

[9] FREIRE, Paulo. Pedagogia da autonomia: saberes necessários à prática educativa. São Paulo: Paz e Terra, 1996.

[10] GIL, A. C. Como elaborar projetos de pesquisa. - 5. ed. - São Paulo: Atlas, 2010.

[11] GOULART, I. B. A educação na perspectiva construtivista: reflexões de uma equipe interdisciplinar. Petrópolis, RJ: Vozes, 1995.

[12] LAKATOS, E. M. Fundamentos de metodologia científica. -5. ed. - São Paulo: Atlas 2003.

[13] MOYLES, Janet. Fundamentos da Educação Infantil: enfrentando o desafio. - Porto Alegre: Artmed, 2010.

[14] NORONHA, G.A. NORONHA, C. A. A Leitura no ensino de matemática: uma prática latente e imprescindível. Anais do II Seminário de Escrita e Leitura em Educação Matemática. São Paulo. p. 1-X, 2013.

[15] PAIS, L. C. Ensinar e aprender Matemática. - Belo Horizonte: Autêntica, 2006.

[16] PERRENOUD, F. Dez novas competências para ensinar. - Porto Alegre: Artmed, 2000.20 
[17] SANTOS, A. R. dos. Metodologia científica: a construção do conhecimento. - 7. ed. rev. - Rio de Janeiro: Lamparina, 2007.

[18] SANTOS, I. E. dos. Manual de métodos e técnicas de pesquisa científica. - Niterói, RJ: Impetus, 2013.

[19] SANTOS, S.M. P. dos. O lúdico na formação do educador. 9.ed. - Petrópolis, RJ: Vozes, 2011.

[20] TOCANTIS. Fundação Universidade do Tocantins UNITINS/ Empresa de Educação Continuada. - Palmas: EDUCON, 2007.

[21] TOLCHINSKY, L. Processo de aprendizagem e formação docente em condições de extrema diversidade. Porto Alegre: Artmed, 2004. 


\section{Capítulo 9}

\section{Ensino da matemática e prática docente: Memórias escolares da tabuada em narrativas de idosos(as)}

\section{José Jorge Casimiro dos Santos \\ Zélia Maria de Arruda Santiago}

Resumo: 0 aumento da população idosa é uma realidade no cenário mundial, igualmente, no contexto brasileiro que em 2030 atingirá um percentual de 20\%, em muitos países europeus $80 \%$ da sua população será idosa em 2050. A sociedade brasileira preocupa-se com suas demandas socioculturais, especialmente educacionais, pois muitos idosos sequer possuem a formação escolar básica. Atualmente, muitos retornam a sala de aula, deparando-se com práticas pedagógicas distantes de suas experiências escolares, por isso, desestimulados na disciplina de Matemática, pois desejam estudar as operações básicas na tabuada. Informações verificadas na análise de memoriais escritos por educandos(as) idosos, cujas práticas de aprendizagem davam-se por meio da tabuada tanto da parte do professor quanto da parte dos alunos, sempre acompanhada da palmatória, motivo de desistência e abandono escolar, mas, também, aprendizado deste conteúdo. Entende-se que estes registros referem-se ao seu contexto educacional, mas orientam a refazer pedagógico das aulas de Matemática, sobretudo no ensino da EJA, pois o professor convive com estas lembranças e reivindicações de educandos adultos e idosos.

Palavras-chave: Memórias. Tabuada. Matemática. Prática docente. 


\section{INTRODUÇÃO}

Vivemos em uma sociedade em constante crescimento, o aumento da população, principalmente a população idosa, devido ao aumento da expectativa de vida e a diminuição da taxa de natalidade, vem sendo palco de discussões mundiais. De acordo com dados da Organização das Nações Unidas (ONU). Estima-se que para 2030, 20\% da população brasileira terá mais de 60 anos, neste sentido, há projeções que nos países europeus mais desenvolvidos em 2050, 80\% da sua população será idosa (MASCARO 2004). Consideramos uma pessoa idosa, aquela de possui idade igual ou superior a 60 anos. Nessa perspectiva, é importante ressaltar que o envelhecimento humano pode ser diferenciado e caracterizado sobre vários conceitos. Segundo Mascaro apud Abreu e Wagner (2004), a idade pode ser: Cronológica (marcada pela data de nascimento); Biológica (determinada pela herança genética e pelo ambiente); Idade Social (relacionada a normas, crenças, estereótipos e demandas sociais) e Idade psicológica (envolve as mudanças de comportamento decorrentes das transformações biológicas). Sendo assim, uma pessoa pode ter diferentes "tempos" e essas idades, não necessariamente, ocorrem simultaneamente. Uma pessoa pode ter atingido a idade cronológica (60 anos), mas não ter atingido a idade biológica, ou então, ela pode atingir a idade social como por exemplo: aderindo a comportamento ditos de pessoas idosas como o modo de se vestir, falar e não ter atingido a idade cronológica. As questões da velhice são tratadas por alguns autores como uma questão de 'sentir', isso vai muito além da idade cronológica. 0 processo de envelhecimento humano não decorre apenas de um fator ele é mais amplo e precisa ser considerado em um contexto mais geral levando em consideração fatores como: mudanças biológicas, psicológicas, o contexto social, o ambiente em que ele está inserido, dentre outros. Junto com o crescimento da população idosa crescem também as demandas sociais e educacionais.

Atualmente temos uma geração de idosos(as) ativos que mantém a sua capacidade de permanecerem como atuantes mediante as demandas sociais. No contexto atual em que a população idosa seja expressiva, a velhice é percebida por muitos, como sinônimo de fraqueza ou inutilidade, cuja percepção ocasiona formas de exclusão social, descaso, violência, discriminação, isto sendo tipos de violência vivenciada e enfrentada pela maioria dos idosos(as). Nessa perspectiva, o contexto educacional não fica de fora, muitos educandos idosos procuram a educação formal como forma de engajar-se no contexto social, e essa, muitas vezes, também se torna um fator de exclusão, tendo em vista que esta se projeta em função dos jovens.

É preciso superar a falsa ideia de que a pessoa idosa e inútil e incapaz, tornando-se um "peso" para a sociedade. Beauvoir (1990) destaca que é a classe dominante que estigmatiza as pessoas idosas e a população ativa se faz cúmplice dela. Mascaro (2004) menciona que as ideias apresentadas na mídia sobre envelhecimento e a velhice são significativas, pois podem oferecer um ponto de referência para os próprios idosos influenciando seus comportamentos e suas atitudes e também as ideias da criança, jovens e adultos o respeito que significa envelhecer na nossa sociedade.

O idosos(as) apresentam vivências e comportamentos diferentes daquelas típicas dos jovens e dos adultos, mas isso não que são incapazes. A nova geração de idosos(as) é cada vez mais participativos, ativos socialmente, estão presentes na política, na economia, em projetos comunitários, entre outros setores. Isso demonstra um comportamento diferente da geração anterior. Mas, infelizmente ainda existe uma invisibilidade em torno da velhice. Pereira (2012) comenta que "a velhice pode ser objeto de uma construção social da invisibilidade".

Nessa perspectiva, homens e mulheres, quando atingem a idade cronológica da velhice, vão perdendo a visibilidade e tornando-se "esquecidos socialmente" do contexto social e familiar. Ainda em termos educacionais, ainda vivemos numa sociedade competitiva e segregacionista, pois quanto ao mercado de trabalho e ocupação social, tal sociedade se programa para conduzir os jovens e adultos, jamais os idosos(as). Esses (as) que, por sua vez, trazem consigo uma larga experiência adquirida ao longo dos anos. A troca de experiências intergeracionais é de extrema importância, e um dos ambientes onde essa troca deve ocorrer é a própria escola. Junto com a população idosa cresce a demanda educacional seja em um ambiente formal (normalmente as escolas que possuam a modalidade EJA) ou informal (as universidades abertas à maturidade - UAMAs).

A Educação escolar possibilita a visibilidade diferenciada de idosos(as) na sociedade, tendo em vista tornarem-se atores sociais acessando informações e conhecimentos necessários a sua formação continuada, logo ela tem grande responsabilidade nesse processo, especialmente ao se tratar da disciplina de Matemática, haja vista sua relevância nos níveis educacionais, embora muitos não tenham tido por ela elevada simpatia. A Memória escolar relacionada ao ensino e a prática docente do professor de Matemática em muitos casos ainda é traumática, principalmente em relação à presença do professor em 
sala de aula. Nesse sentido, surgem algumas questões pertinentes a esta pesquisa: (i) Que conteúdos matemáticos são narrados por educandos idosos(as) em seus memoriais escritos? (ii) Como estes conteúdos dialogam com a prática docente do professor de Matemática na EJA?

Apesar da Matemática percebida por muitos como uma disciplina difícil e, muitas vezes, associada a um 'monstro', ela é reconhecida como indispensável no meio social e cotidiano. Isso acontece, principalmente pelo fato de os mesmos não estabelecerem relação da Matemática escolar com a Matemática do uso cotidiano. No entanto, umas das formas de estabelecer essa conexão é o diálogo que sonda, tematiza e problematiza a matemática da vida cotidiana (FREIRE, 2005). Visão próxima as colocações de D’Ambrosio (2012) ao afirmar que o "objetivo do diálogo é criar um ambiente menos inibidor para os ouvintes" da vida cotidiana que possui muitos saberes matemáticos. Este diálogo com a realidade é um indicativo metodológico essencial na aprendizagem da matemática ou qualquer conteúdo (FREIRE, 2005), sendo indispensável à liberdade de aprender, portanto, este autor evidencia sua importância nas relações interpessoais no processo da aprendizagem ocorrida na escola. Este artigo objetiva analisar memoriais escritos por educandos idosos de um curso de extensão, quanto aos saberes escolares da Matemática, verificando como estes conteúdos dialogam com a prática docente de professores desta disciplina.

Os memoriais são acervos ricos em informações que refletem aspectos de uma marca temporal específicos. 0 memorial das pessoas idosas da UAMA representa um espaço para que estes relatem a história de suas vidas e que outras pessoas incluindo os pesquisadores, possam conhecê-las e estudá-las com mais profundidade (SILVA e SANTIAGO, 2017). Nessas histórias encontramos indícios sobre o contexto educacional daquela época, tais como a organização do ambiente, as metodologias utilizadas, a forma de avaliação utilizada pelo professor e as demandas de aprendizagem (especificamente em Matemática), essas informações servem como subsídios para se repensar a prática docente do professor.

\section{METODOLOGIA}

Este trabalho consiste em uma pesquisa documental cujo foco são os memoriais escritos por educandos idosos participantes de UAMA. Ela é um projeto de extensão, criado pela Universidade Estadual da Paraíba (UEPB) que está na ativa desde 2009 atendendo a população idosa de Campina grande e cidades circunvizinhas. 0 curso tem um total de 1200 horas atuando sobre os eixos: saúde, Saúde e Qualidade de Vida; Educação e Sociedade; Cultura e Cidadania e Arte e Lazer. A UAMA tem como objetivo atender a demanda educativa dos idosos proporcionando-lhes uma melhoria na sua qualidade de vida numa perspectiva inclusiva.

A pesquisa documental é compreendida como um tipo como um tipo de estudo que é baseado em documentos considerados cientificamente autênticos. Apesar de a pesquisa documental abranger uma variedade de documentos, optamos por analisar apenas os memoriais tendo em vista a ter um melhor delineamento da pesquisa. Foram analisados trinta (30) memoriais que foram escritos entre os anos de 2011 a 2015, mas que fazem referência a lembranças de pessoas que nasceram aproximadamente entre as décadas de 30 a 50.

\section{RESULTADOS E DISCUSSÕES}

\subsection{SABERES MATEMÁTICOS: NARRATIVAS DE IDOSOS(AS)}

Como norte desta discussão tem-se trechos narrados através dos memoriais. Um desses educandos destaca que: "Lembro que aprendi as minhas primeiras letras em uma carta do ABC, e os números com a tabuada (...)" A tabuada, naquela época, era o único recurso utilizado para o ensino das operações básicas disponível, a forma como ela era utilizava, em alguns casos, causava traumas, a figura do professor também contribuía para o acontecimento desses traumas. “(...) tinha o argumento de que de tabuada e quem não soubesse levava bolo de palmatória ${ }^{1}$, nas mão e foi lá que eu aprendi a tabuada e nunca mais esqueci! Logo depois fui estudar no grupo escolar São José no centro de lagoa seca, tinha 10 anos e já sabia ler e escrever". A tabuada teve início no Brasil durante o império, segundo Valente (2007), a tabuada deveria ser um conhecimento permanente do aluno, sendo que, esse conteúdo deve ser memorizado pelo aluno.

\footnotetext{
${ }^{1}$ Instrumento de madeira formado por uma base e um circulo na ponta, que durante muito tempo foi utilizado por professores em sala de aula como forma de castigo.
} 
Não acertar as perguntas feitas pela professora era sinônimo de castigo, onde os alunos eram submetidos à palmatória (instrumento quase sempre citado nos memórias sempre quando reportados sobre o tempo escolar). 0 processo de ensino e de aprendizagem em Matemática era feito de forma mecânica e desprovido de sentido. "Minha primeira escola era particular (...) com ela aprendi a Carta do $\mathrm{ABC}^{2}$, a tabuada e a cartilha do povo(...). Lembro-me da forma como aprendia, pois esse tempo tinha o argumento de que, que eram perguntas entre alunos, fazíamos um ao outro e quando um não respondia correto, tinha a palmatória que servia de castigo na forma de "bolo", eu levei várias, mas também deu os meus colegas que não respondiam certo". Com as mudanças na educação, o ensino da tabuada vem ganhando novas formas e novos métodos. Entende-se que seu ensino deva ser pautado não na memorização pura e simples, mas com significado. Mendes e Valente (2017) destacam que tal dispositivo pedagógico atravessa séculos e a cada época ganha diferentes formas e usos significativos. A Educação Matemática, por mais de cinquenta anos esteve pautada na memorização e em se tratando da tabuada, ela era recitada 'de cabeça' e de modo cantado. (BACKHUSER, 1946, apud PINTO, 2010).

Em se tratando da figura do professor, ela era bem marcante, a docência era dedicada exclusivamente às mulheres. "Em Quixadá, estudei na escola particular que era uma casa, a tabuada era aprendida com palmatória, eu tinha uma professora muito brava" Em outro depoimento escrito, encontramos "(...) era uma pessoa muito mal-humorada. Ela fazia nas sextas-feiras uma sabatina onde todos os alunos participavam, a criança que errasse a tabuada levava um "bolo" com palmatória" Entendemos que a figura influência na aprendizagem do educando. 0 aluno sente-se mais disposto a aprender quando ele percebe, na figura do professor, um canal de diálogo, uma troca multa de conhecimentos. "A professora era muito exigente, pois no $2^{\circ}$ ano Primário $^{3}$ eu já sabia da tabuada de multiplicar decorada". Mas é pertinente destacar que, mesmo sob condições traumáticas, muitos educandos relatam, através dos escritos, que até hoje sabem e tabuada ou que agradece os métodos utilizados pelas professoras. "Também tinha a tabuada e era a pior parte, quando não acertávamos, tinha a palmatória, foi por isto que muitas crianças tiveram medo de estudar, existiam muitas professoras severas, agiam de forma grosseira, tipo um líder autoritário em sala de aula, ainda bem que isto foi em época passada mesmo assim eu agradeço a minha primeira professora $(. .$.

Os educandos idosos que já possuem nível superior completo ou incompleto, de certa forma já atingiram um nível de estudo 'elevado' e buscam o espaço escolar como forma de ressocialização, da busca pela autoestima, "E para completar a minha felicidade, participo desse curso para idosos - UAMA que muito contribui para a nossa autoestima para continuarmos vivendo positivamente" fator também de interesse dos idosos que também buscam a UAMA, mas outros fatores podem estar agregado como a busca de um ambiente educacional como forma de retomar os estudos, recuperar o tempo considerado perdido "o que me entristece era o fato de ter deixado de estudar... mulher era para se dedicar aos afazeres domésticos e se preparar para ser uma boa mãe e dona de casa", tendo em vista que alguns tiveram que afastar-se da escola para cuidar da casa, da família, para trabalhar e buscar seu próprio sustento.

Independentemente da idade, as pessoas idosas ainda anseiam determinada atingir metas em meio educacional, como por exemplo: "desejo ainda ser muito feliz em minha vida e fazer o ENEM, fazer um curso de história e eu agradeço a Deus e aos meus professores e professoras porque pra mim os senhores são muito importantes e também a UAMA que foi onde eu aprendi muitas disciplinas que eu não compreendia". A UAMA é um projeto de extensão que atende o público idoso, objetivando atender demandas educativas, proporcionando-lhes melhoria na qualidade de vida em termos inclusivos. Essa qualidade de vida pressupõe também melhorar o entendimento sobre o que é velhice. "Hoje vivo uma nova experiência - 0 envelhecer. Acredito que o objetivo é criar condições para viver mais e com mais qualidade entre as pessoas com que vivemos: os filhos, os netos [...]. O envelhecer é uma oportunidade de saber quem nos ama de verdade." A velhice é uma etapa única, marcada por mudanças no âmbito geral, nesse sentido, à Educação pode contribuir para a redefinição de um projeto envolvendo uma melhor qualidade de vida dentro de uma perspectiva de inclusão social e favorecendo uma velhice satisfatória. A ideia de que a pessoa idosa é um incapaz ou debilitado vem mudando. Netto (2001) afirma que cada vez mais os próprios idosos estão rejeitando as representações negativas a respeito da idade e vencendo os preconceitos e estereótipos que cercam sua condição, eles buscam novos espaços e novas formas de participação social.

\footnotetext{
2 Cartilha utilizada no processo de alfabetização.

${ }^{3}$ Primeiro estágio da educação escolar, hoje é equivalente aos anos iniciais do ensino fundamental.
} 


\section{CONSIDERAÇõES FINAIS}

A matemática não é algo estático, pelo contrário, ela é dinâmica e está sempre em movimento, sua rotatividade é uma das grandes responsáveis pelo desenvolvimento que se tem hoje. Os conteúdos não são os mesmos, mas a forma como eles são aperfeiçoados e trabalhados em sala de aula ganha cada vez mais destaque. Percebe-se que a tabuada está muito presente nos memórias e essas memórias estão, em alguns casos ligados a momentos traumáticos seja com relação ao método ou com relação à figura do professor, este último, sempre ligado a uma figura autoritário. Compreende-se que as experiências escolares com o uso da tabuada narradas por diferentes sujeitos através dos memoriais podem ser utilizadas pelo professor de Matemática na EJA, não apenas para dinamizar suas aulas, mas contribuir com a aprendizagem dos seus educandos. Considerando a UAMA, entende-se que ela trabalha propostas que voltadas a atualização, valores e atitudes das pessoas idosas, ligadas a atividades sociais e culturais também, o que possibilita a integração dessas pessoas no mundo em constante transformação, contribuindo, de modo concreto para uma melhor qualidade de vida às pessoas idosas e ampliando as discussões sobre a velhice.

\section{REFERÊNCIAS}

[1] BEAUVOIR, S. A velhice. Rio de Janeiro: Nova Fronteira, 2001

[2] D’AMBRÓSIO, U. Educação matemática: Da teoria à prática. Campinas, SP: Papirus, 2012.

[3] FREIRE, P.. Pedagogia do Oprimido. 42. ed. Rio de Janeiro: Paz e Terra, 2005.

[4] MASCARO, S. A. O que é velhice. São Paulo: Brasiliense, 2004.

[5] MENDES, I. A.; VALENTE, W. R. A matemática dos manuais escolares: curso primário, 1890-1970. São Paulo: LF Editorial, 2017.

[6] NETTO, A. J. Universidade Aberta para a maturidade: avaliação crítica de uma avançada proposta educacional social. In: KACHAR, V.(org). Longevidade: um novo desafio para a educação. São Paulo: Cortez, 2001.

[7] PEREIRA, J. M. M. A escola do riso e do esquecimento: Idosos na educação de jovens e adultos. Juíz de Fora, 2012. Disponível em: http://www.ufff.br/revistaedufoco/files/2012/08/Texto-014.pdf. Acesso em 09 de set de 2016

[8] PINTO, N. B. O impacto da educação matemática moderna na cultura da escola primária brasileira. In MATOS, J. M.; VALENTE, W. R. A reforma da Matemática moderna em contextos ibero-americanos. Lisboa: Várzea da Rainha Impressores SA, Faculdade de Ciência e Tecnologia da Universidade Nova Lisboa, 2010.

[9] SILVA, R.; SANTIAGO, Z. M. A. Memorial escrito e relatos de aprendizagens de pessoas idosas: ressignificação da vida cotidiana. In: RASIA, M. G. R.; MELO, R. A.; SANTIAGO, Z. M. A. Desenvolvimento humano e educação escolar: enfoques teóricos e práticas educacionais. João Pessoa: Ideia, 2017.

[10] VALENTE, W. R. Uma história da matemática escolar no Brasil 1730-1930. Annablume. 2. ed. São Paulo, 2007. 


\section{Capítulo 10}

\section{Uma reflexão sobre a educação matemática no ensino de jovens e adultos}

\section{Bruno Thayguara de Oliveira Ribeiro \\ Eloy da Silva Rocha}

Resumo: A educação de Jovens e Adultos possui um contexto histórico influenciado por questões políticas que não possuíam como objetivo ter o estudante como ser que está no centro de um processo de formação pedagógica e que à medida que essas políticas sofreram influência de teóricos e movimentos sociais tornaram a EJA uma modalidade de ensino que possui uma especificidade que abrange um grande número de grupos compostos por trabalhadores, idosos, adolescentes e pessoas com necessidades especiais e estudantes com distorção idade-série. A EJA não pode ser tratada como um retalho de políticas adaptadas, mas como uma modalidade de ensino que requer políticas próprias, nesse contexto a matemática deve auxiliar o estudante a compreender as noções lógico-sociais de maneira significativa, tornando o ensino mais próximo da realidade dos estudantes que compõem os diversos grupos da EJA.

Palavras-chave: Educação, jovens, adultos, matemática. 


\section{INTRODUÇÃO}

A EJA (Educação de Jovens e Adultos) é uma modalidade de escolarização para os estudantes que não conseguiram ingressar na escola no período regular. Esta modalidade nos dias atuais dá a muitos grupos sociais que estão descolados no processo de ensino-aprendizagem a oportunidade de formação do cidadão reflexivo e crítico e consciente de sua importância dentro de um contexto social.

Dentro do nosso contexto atual a EJA ainda é situada como uma modalidade deixada à parte nos quadros de políticas e metodologias, a secretarias trata esse programa de ensino apenas no aspecto prático, ressalvando resquícios e objetivos históricos que por vezes situam a EJA como um método de dar diplomas de maneira rápida ao estudante que ainda não o possui e deixa a qualidade de ensino de lado, não favorecendo os diversos grupos que a compõe realmente.

A matemática não pode ser tratada no contexto da EJA como uma disciplina na qual o professor copia o conteúdo do ensino regular e repassa a noite, tratando o estudante como depósito que deve ser preenchido no mais hábil tempo, conduta condenada por Paulo Freire que foi uma das mais notáveis referências no que hoje consideramos educação voltada para Jovens e Adultos.

Entender quais grupos estão inseridos nessa modalidade de ensino e verificar que metodologias estão corretamente adequadas a esses grupos deve ser o aspecto norteador que deve prevalecer nas secretarias tanto municipais quanto estaduais de ensino, respeitando assim o que rege nossa Constituição:

"A educação é direito de todos e dever do Estado e da família..." (Artigo 205) e ainda, ensino fundamental obrigatório e gratuito, inclusive sua oferta garantida para todos os que a ele não tiveram acesso na idade própria (artigo 208, BRASIL, 1988).

\section{METODOLOGIA DA PESQUISA}

Para a construção da pesquisa foi realizada uma análise da proposta curricular da EJA presente na Secretaria de Educação do município de Manaus, onde dentro da pesquisa foi analisada o conteúdo da proposta do $1^{1}$ o segmento em relação aos quatro bimestres e sua correlação matemática envolvendo a lógica desses conteúdos, sendo que a mesma é dividida em habilidades e conteúdo, nesse parâmetro foi comparada a correspondência entre esses conteúdos e suas habilidades levando em consideração as especificidades que cercam a modalidade de ensino.

Após a etapa da analise da proposta curricular foi realizada uma pesquisa documental a respeito do histórico da EJA para correlação política e compreensão dos fatos com a atual situação na presente secretaria, posteriormente a pesquisa documental deu-se através de consulta na GEJA que é Gerência de Educação de Jovens e Adultos, onde foi realizada pesquisa acerca dos índices de aprovação, reprovação e abandono no devido segmento para comparação com a situação dessa proposta de matemática, onde a pesquisa deu-se no âmbito de responder se a construção de uma proposta com problemas de estruturação lógica afetou o desempenho dos estudantes do segmento avaliado e como a falta de formação adequada para os professores afetou esse quadro na rede municipal pesquisada.

\subsection{HISTÓRICO DA EJA}

Inicialmente a pesquisa documental começa com uma análise histórica para situar a EJA no contexto político, entendendo como dar-se-á a construção dessa modalidade de ensino e os aspectos que estão envolvidos nesse contexto histórico.

A EJA (Educação de Jovens e Adultos) vem como uma oportunidade para levar educação para quem não conseguiu entrar na escola no tempo regular ou para aqueles que por alguma especificidade relacionada à carga de trabalho, família entre outros não conseguiram concluir seus estudos. 
Observa-se que a EJA tem seu início na época do Brasil Colônia onde o caráter era doutrinação religiosa e com o passar do tempo começou a tomar novos rumos e sob a égide de nossa Constituição, com um ensino laico segundo os documentos oficiais.

[...] do século XIX e início do século XX, num contexto de emergente desenvolvimento urbano industrial e sob forte influência da cultura europeia, são aprovados projetos de leis que enfatizam a obrigatoriedade da educação de adultos, objetivando aumentar o contingente eleitoral, principalmente no primeiro período republicando e, consequentemente atender aos interesses das elites. (ZANETTI, p. 1,2015).

Com o avanço da sociedade industrial e urbanização do país, tornou-se fundamental para o desenvolvimento do país, alfabetizar esses trabalhadores, surge então projetos e campanhas para os que não haviam concluído a escola em período regular. Paulo Freire traz então a proposta de olhar esse estudante com um ser que necessita de uma educação não apenas baseada no sistema de depósito, mas tornando o estudante como centro de um processo de transformação social. Essa visão deve ser lembrada quando o docente for elaborar suas avaliações ou mesmo fazer o planejamento de seus conteúdos, levando em conta toda especificidade da EJA.

A história da EJA é marcada por conferências que tentaram trazer toda a especificidade de maneira a sensibilizar todos os setores da sociedade, do ponto de vista da internacionalização da EJA, as CONFINTEAS representam um marco político e regulatório muito importante, promovidas pela UNESCO. Essas conferências refletiam o momento histórico em que se situavam as políticas econômicas e sociais de cada época.

CONFINTEA significa Conferência Internacional de Educação de Adultos e são eventos promovidos periodicamente pela UNESCO, a partir da primeira metade do século XX. Essas conferências são pensadas, planejadas e organizadas com o objetivo de construir as Diretrizes e as Políticas Globais em face da problemática da EJA. Ao longo das últimas décadas, foram realizadas seis Conferências e cada uma delas resultou na sistematização de documentos para subsidiar as ações da EJA em cada país participante. (Políticas Públicas para Educação de Jovens e Adultos Integrada à Educação Profissional-IFAM/RN2019).

\subsection{AVALIAÇÃO MATEMÁTICA NA EDUCAÇÃO DE JOVENS E ADULTOS}

Historicamente, a modalidade de EJA foi negligenciada por parte dos governos quanto à investimentos e estruturas e isso influenciou no avanço de novas metodologias de avaliação voltada para ensino da EJA. Na avaliação matemática, ainda ocorre certa resistência a estratégias não tradicionais de ensino tanto por parte dos professores, quanto por parte dos estudantes. Muitos docentes de matemática ainda se confundem, pois, as propostas pedagógicas estão na condição de "não-criança" estão relacionadas somente as limitações impostas pelas estruturas escolares. Há poucos suportes teóricos voltados as especificidades acerca dos processos cognitivos da vida adulta.

Os processos de construção do conhecimento e de aprendizagem dos adultos são assim, muito menos explorados na literatura psicológica do que aqueles referentes às crianças e adolescentes... A pequena atenção dedicada ao desenvolvimento humano após a adolescência pode estar relacionada a um modo de conceber a idade adulta, tradicionalmente encarada como um período de estabilidade e ausência de mudanças. (OLIVEIRA, 1999 apud FONSECA 2012)

O fracasso escolar no ato de avaliar referente à matemática não está apenas no fator evasão escolar, mas na falta de políticas que estimulem dentro das secretarias uma proposta voltada para matemática contextualizada para EJA, o que muitas vezes gera uma inadequação das propostas pedagógicas que pode ser identificada com a infantilização das estratégias de ensino e das atividades. 
Na Secretaria Municipal de Manaus a exemplo, a proposta matemática da EJA, traz um resumo dos descritores do ensino fundamental regular, o que não constitui uma base matemática voltada para EJA. 0 docente ao avaliar esse estudante usará essa proposta como eixo norteador e isso irá impactar o resultado, pois as avaliações serão elaboradas com base em uma proposta que muitas vezes estará aquém a realidade da EJA.

Uma base matemática que fosse construída levando em conta a especificidade da EJA influenciaria no processo de ensino-avaliação de maneira a contextualizar o estudante dentro do conceito matemático.

Os registros das estratégias adotadas pelos alunos na resolução de problemas ou nas atividades propostas podem auxiliar sobremaneira a compreensão de sua forma de organizar e mobilizar o conhecimento adquirido/construído de modo a (re)orientar a própria avaliação do trabalho, bem como as intervenções do professor nas negociações de significados e do contrato didático.(PAIS, 2001 apud FONSECA 2012)

O processo de avaliar passa pelo ato de ensinar, ou seja dentro do contexto o estudante não teria uma organização curricular linear dos conteúdos, mas uma organização que levasse em conta sua realidade e o docente por sua vez realizaria a avaliação contextualizando com essa "realidade" do estudante da EJA, não apenas em 1996 foi realizado um seminário preparatório da V CONFINTEA que consolidou documento intitulado Elementos para um diagnóstico da EJA no Brasil, que estabeleceu os princípios norteadores da educação de jovens e adultos e destacou os vinte e sete compromissos elencados.

0 Artigo 13ำ recomendou: "Estruturar programas alternativos de educação continuada que incluam as seguintes dimensões da EJA: d) educação e trabalho: articulação entre escolas e instituições de formação profissional para a oferta de cursos profissionalizantes" (BRASIL, 2004a, p.36-37).

Ao avaliar o estudante da EJA o docente deve levar em conta os diversos grupos e diversos aspectos cognitivos que compõe sua sala de aula, no caso da matemática, o docente deve levar em conta os aspectos referentes à alfabetização desse estudante, que muitas vezes é fragmentada, realizar exames de verificação se torna uma estratégia útil para saber como está o conhecimento matemático, esse conhecimento deve auxiliar o estudante da EJA no campo da sua vida profissional no que tange às suas necessidades que tornam o ensino significativo.

Usar jogos matemáticos em grupos, mostra-se uma estratégia interessante para trabalhar determinados conteúdos ou até mesmo pode ser usado como uma das avaliações pontuais, tendo em vista que quebra a expectativa de avaliação, ou seja, o estudante será avaliado de maneira mais sensível com relação ao aspecto psicológico, deixando aquele tipo de avaliação tradicional escrita como apenas uma das várias maneiras de se avaliar o estudante.

\subsection{FORMAÇÃO DO PROFESSOR DE MATEMÁTICA PARA EJA}

$\mathrm{O}$ ato de avaliar não se inicia quando o docente assume uma carga de matemática em uma turma de EJA, mas quando o estudante de ensino médio decide ingressar num curso de licenciatura em Matemática. É importante ressaltar que as universidades quando se trata de cursos de exatas, se preocupam muito com a formação técnica e nos cursos de licenciatura, em especial de matemática, deixam a desejar com a formação didática, pois como afirma Shulman (1986 apud PONTE, 1999, p. 3) “o professor tem de conhecer bem os conteúdos que ensina, mas não precisa conhecer da mesma forma que o cientista. 0 professor tem que conhecer as boas maneiras de torna-los compreensíveis e relevantes para os alunos".

As disciplinas de psicologia, didática e pedagógicas em geral são encaradas muitas vezes nos cursos de licenciaturas em matemática como complemento para carga, e isso influência de maneira negativa na formação inicial desses professores que é abordada por Costa e Allevato (2014) quando dizem que:

É na formação inicial que os (futuros) professores têm contato explícito com aspectos sobre o que é ensinar. Daí a importância de associar teoria e prática, pois é durante a formação inicial que esses (futuros) professores terão a oportunidade de refletir e discutir sobre teorias, estratégias ou metodologias de ensino, sobre os conteúdos e sobre o material didático que servirão de suporte em sua prática docente (p.129). 
As universidades devem investir mais na formação dos futuros licenciados que devem possuir uma formação que contemple não apenas a álgebra, geometria, aritmética, pois como o próprio nome do curso já diz é "licenciatura" e não de bacharelado e por mais redundante que possa parecer tal afirmação, muitos coordenadores de curso de exatas ignoram e acabam montando grades de cursos que de licenciaturas viram "bacharelados disfarçados". Prejudicando de maneira substancial a formação desse profissional da matemática, que sai da universidade tendo um bom currículo na área específica, mas que muitas vezes não reconhece um estudante com discalculia em sua própria sala. Fica a reflexão sobre o profissional da matemática que a universidades está formando e seu impacto na educação de nossos jovens e adultos.

As secretarias ao receber o profissional de matemática devem por sua vez, investir em formações continuadas, principalmente na área de Educação de Jovens e Adultos, quando este profissional for atua com esse público. Pois nessas formações esse profissional irá compreender toda especificidade que abrange a EJA, aprendendo a realizar testes diagnósticos, analisar proposta curricular, fazer adaptações e inferências e recebe treinamento referente a novas metodologias voltadas para EJA. Com isso esse professor de matemática irá desenvolver um trabalho significativo e sua avaliação será diferenciada, contextualizada e tornará o processo de ensino-avaliação produtivo para esse estudante, respeitando assim esse público que muitas vezes é esquecido de metodologias diferenciadas.

É preciso respeitar o aluno através de uma metodologia apropriada, uma metodologia que resgate a importância da sua biografia. [...] Os jovens e adultos alfabetizados já foram desrespeitados uma vez quando tiveram seu direito à educação negado. Não podem agora, ao retomar sua instrução, serem humilhados mais uma vez por uma metodologia que lhes nega o direito de afirmação de sua identidade, de seu saber, de sua cultura (GADOTTI, 2003, p. 3).

\subsection{RESUlTADOS DA PESQUISA DOCUMENTAL FEITA A PARTIR DA PROPOSTA CURRICULAR DE MATEMÁTICA NA 1a FASE DA EJA}

A proposta traz com um dos seus objetivos "valorizar a matemática como instrumento para interpretar informações sobre o mundo, reconhecendo sua importância em nossa cultura". Para isso o estudante da EJA precisa de uma sequência lógica de conteúdos de matemática para que o mesmo consiga construir essa base, e isso fica um pouco confuso nessa proposta, inicialmente a mesma traz para a $1^{\mathrm{o}}$ fase no $1^{\mathrm{o}}$ bimestre.

Fig.1. Proposta Matemática/EJA- pág.98

\begin{tabular}{|c|c|}
\hline \multicolumn{2}{|c|}{$I^{\circ}$ BIMIESTRE } \\
\hline \multicolumn{2}{|c|}{ CONHECIMINTO DA AREA: NÜMIEROS E OPERAC ŌES NUMERICAS } \\
\hline HABILIDADES & CONTEUDOS \\
\hline $\begin{array}{l}\text { - Compreender os números e conlecer suas } \\
\text { diversas funçōes. } \\
\text { - Identificar códigos numéricos frequentes nas } \\
\text { atividades do cotidiano. } \\
\text { - Estimar e verificar quantidades por meio de } \\
\text { contagem. } \\
\text { - Utilizar diferentes estratégias de contagem: de } \\
\text { dois em dois, de cinco em cinco, de dez em dez, } \\
\text { de cem em cem. } \\
\text { - Ler e escrever números até unidade de milhar. }\end{array}$ & - Números naturais e sistema de numeração. \\
\hline
\end{tabular}

Inicialmente antes de entrar na noção de números naturais e numerais, a proposta deveria trazer como primeiro tópico a noção de conjunto, para que o estudante comece a entender de maneira paulatina o conceito de número e numeral, trazendo também o conceito de conjunto unitário, vazio, subconjuntos e as operações com reunião de elementos, diferença de conjuntos e intersecção de conjuntos, com esses conteúdos o estudante começa a ter a noção de maneira subjetiva de número e numeral, seguindo uma sequência lógica, quando o professor de matemática inicia seu trabalho com essa noção de conjuntos, torna-se mais fácil para o estudante compreender o que é um número natural, pois o professor primeiramente irá definir o conjunto de números naturais, pois o estudante já tem em seu campo mental a noção de conjuntos que falta nessa proposta que se inicia com números naturais de maneira solta e descontextualizada. 
Aprender Matemática é aprender a resolver problemas. Para isso é preciso apropriar-se dos significados dos conceitos e procedimentos Matemáticos para saber aplicá-los em situações novas. Assim é fundamental que tais conceitos e procedimentos sejam trabalhados com a total compreensão de todos os significados associados a ele (DANTE, 2002, p.11).

A proposta chama a atenção porque traz em seguida no $1^{0}$ bimestre as operações básicas, adição, subtração, multiplicação e divisão num bloco único, ou seja, professor vai definir em um bimestre toda introdução de número, numeral e sistema de base decimal que requer decomposição canônica e nãocanônica é um tópico difícil para os estudantes da EJA segundo pesquisa feita no órgão de avaliação do município, no mesmo bimestre todas as operações básica, não respeitando a questão de que o estudante da 10 fase da EJA é muitas vezes um adulto que pode estar a muito tempo sem estudar, pessoas com transtornos cognitivos e idosos, ou seja, estamos tratando esses estudantes como "ensino regular" e não respeitando que segundo KASIM (2018, pág., 3) “ A EJA tem uma especificidade que precisa ser respeitada, como por exemplo, ter como ponto de partida os conhecimentos prévios do estudante e as expectativas de vida que o mesmo tem, as quais provavelmente o levaram a voltar a estudar".

Contextualizar a Matemática é essencial para todos. Afinal, como deixar de relacionar os elementos de Euclides com o panorama cultural da Grécia antiga? Ou a adoção da numeração indo-arábica na Europa com o florescimento do mercantilismo nos séculos XIV e XV? E não se pode entender Newton descontextualizado (D’AMBRÓSIO, 2005 p. 76-77).

Essa confusão na hora de montar essa proposta prejudica o estudante na hora de desenvolver um raciocínio lógico, pois os tópicos acima são trabalhados como eixo separados que não se completam, ou seja, eles serão trabalhados sem contextualização e pode gerar na cabeça do estudante da EJA um emaranhado de conteúdos soltos que não se completam e sem sentido. Esse tipo de proposta pode prejudicar o professor na hora de gerar situações problemas que tem por objetivo estimular o estudante.

Um dos principais objetivos do ensino de matemática é fazer o aluno pensar produtivamente, para isso, nada melhor que apresentar-lhe situações-problema que o envolvam, o desafie e o motivem a querer resolvê-las (DANTE, 1991, p.11)

A confusão na proposta continua no quarto bimestre, pois não se sabe se por falta de conteúdo, ou confusão na hora de montar a proposta, os problemas com as quatro operações que aparecem primeiro bimestre, voltam com o mesmo texto, seguidos dos tópicos de coleta da informação.

Fig 4.. Proposta Matemática/EJA- pág.101

\begin{tabular}{|c|c|}
\hline \multicolumn{2}{|c|}{ I'BIMESTRE } \\
\hline \multicolumn{2}{|c|}{ CONHECIMINTO DA AREA: NUMIEROS E OPERACOES NUMERICAS } \\
\hline HABILIDADES & CONTELDOS \\
\hline $\begin{array}{l}\text { - Resolver problemas com nímeros naturais, } \\
\text { envolvendo os diferentes significados da adiçầo. } \\
\text { subtraçāo, multiplicação ou divisĩo. } \\
\text { As babilidades estào relacionadas aos } \\
\text { descritores: D18 e D20. }\end{array}$ & $\begin{array}{l}\text { - Adiçào. } \\
\text { - Subtraçào. } \\
\text { - Multiplicação. } \\
\text { - Divisẫo. }\end{array}$ \\
\hline \multicolumn{2}{|c|}{ CONHECIMIENTO DA AREA: INTRODUÇẢO A ESTATISTICA } \\
\hline HABILIDADES & CONTEŨDOS \\
\hline $\begin{array}{l}\text { - Coletar e organizar dados e informaçòes. } \\
\text { - Construir registros pessoais para comunicar } \\
\text { informaçōes coletadas. } \\
\text { As habilidades estào relacionadas aos } \\
\text { descritores: D28. }\end{array}$ & $\begin{array}{l}\text { - Noşôes de coleta, sistematizaçào e análise dos } \\
\text { dados. }\end{array}$ \\
\hline
\end{tabular}

A proposta está dividida de maneira confusa, pois o estudante poderia ver em dois bimestres todos os tópicos referentes às operações básicas, trabalhando a resolução de problemas junto com essas operações, como tópicos que se completam e não separados em diversos campos da proposta como foi mostrado acima, a geometria poderia ser vista junto com as unidades de medida e sendo trabalhada paulatinamente em um bimestre inteiro e quarto bimestre poderia ser dedicado inteiramente ao tratamento dos conceitos 
de estatística, onde o professor poderia trabalhar com diversas metodologias, como pesquisas na própria escola trabalhando a noção de coleta e sistematização e exposição das tabelas construídas pelos estudantes.

Esse tipo de confusão em proposta prejudica o aprendizado das competências e habilidades propostas pela BNCC quando ao raciocínio e consequentemente o letramento matemático.

[...] definido como competências e habilidades de raciocínio, representar, comunicar e argumentar matematicamente, de modo a favorecer 0 estabelecimento de conjecturas, a formulação e a resolução de problemas em uma variedade de contextos, utilizando conceitos, procedimentos, fatos e ferramentas matemáticas. É também o letramento matemático que assegura aos alunos reconhecer que os conhecimentos matemáticos são fundamentais para a compreensão e a atuação no mundo e perceber o caráter de jogo intelectual da matemática, como aspecto que favorece o desenvolvimento do raciocínio lógico e crítico, estimula a investigação e pode ser prazeroso (fruição). (BNCC, p.264)

Dentro dos municípios do Amazonas a modalidade de EJA é oferecida nas escolas municipais no turno noturno, dividas em fases que vão desde a alfabetização ao ensino fundamental, o qual é alocado em duas fases sendo a $4^{\underline{a}}$ fase correspondente ao ensino do sexto e sétimo ano e a $5^{\underline{a}}$ fase correspondente ao ensino do oitavo e nono ano, ou seja, nos anos finais temos 4 anos do ensino fundamental ministrados em dois no ensino de jovens e adultos e, como consequência, temos lacunas na proposta de matemática voltada para Educação de Jovens e Adultos, o que se reflete como uma das possíveis causas nos altos índices de abandono e reprovação que juntos alcançam quase $50 \%$ do total dos estudantes do $1^{\text {o }}$ segmento como mostra os dados da GEJA, a Gerência de Educação de Jovens e Adultos da Secretaria Municipal de Educação.

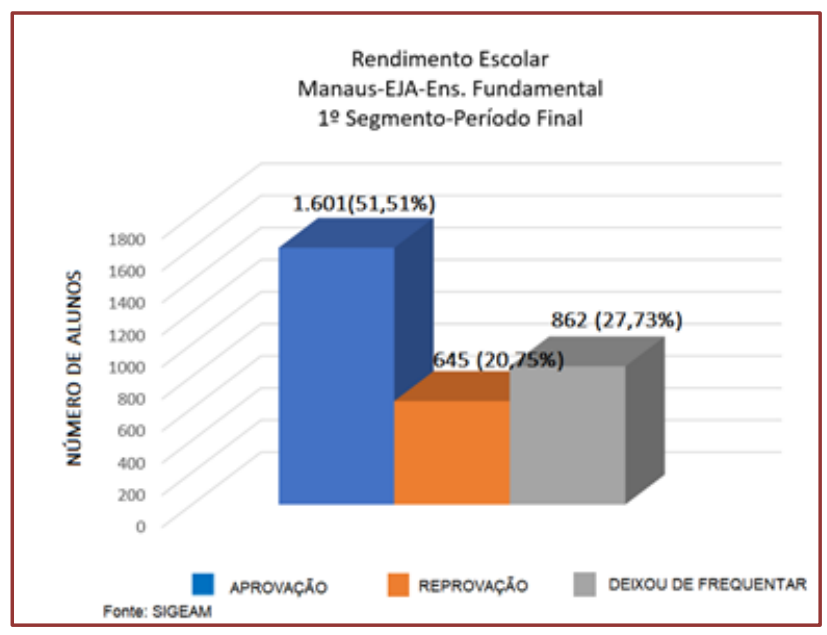

\section{CONSIDERAÇÕES FINAIS}

O processo de avaliação matemática começa na graduação onde os futuros licenciados em matemática devem receber uma formação mais voltada para o cunho pedagógico e não apenas técnica, os futuros professores devem receber uma formação teórica que o auxilie em sala a desenvolver metodologias que mais se adequem a sua realidade e o ajude a identificar estudantes com especificidades que necessitem uma atenção maior. As universidades devem incluir em seu currículo disciplinas voltadas para Educação de Jovens e Adultos no que tange a atender a realidade do ensino básico onde esses estudantes estão inseridos.

As Secretarias devem promover formações que preparem o docente para o trabalho com a EJA, não inseridos diretamente docentes para atuar com esse público, sem que antes os mesmos recebam formação continuada, onde os mesmos recebam toda informação a fim de melhorar o ensino da matemática que por sua vez é um componente curricular que necessita de atenção especial principalmente quando direcionada para EJA. 
As propostas curriculares de matemática devem ser revistas e analisadas por profissionais que tenham formação específica em EJA, afim de não haver construções que não respeitam as reais necessidades dos estudantes e consequentemente auxiliarem o docente no fazer pedagógico e melhorar a construção do processo de avaliação matemática dentro do contexto da EJA.

\section{REFERÊNCIAS}

[1] Brasil, LDB. Lei 9394/96 - Lei de Diretrizes de Bases da Educação Nacional. Disponível em: $<$ www.plantalto.gov.br >. Acesso em: 08 de Ago. 2018.

[2] Brasil. Constituição (1988). Constituição da República Federativa do Brasil: promulgada em cinco de outubro de 1988. Disponível em: <www.plantalto.gov.br >. Acesso em: 10 de Ago. 2018.

[3] Brasil. Resolução CNE/CEB no 1, de 5 de julho de 2000. Estabelece as Diretrizes Curriculares Nacionais para a Educação de Jovens e Adultos. Conselho Nacional de Educação/Câmara de Educação Básica. Diário Oficial da União, Brasília, DF, 9 junho de 2000. Disponível em: <http://portal.mec.gov.br/cne/arquivos/pdf/CEB012000.pdf>. Acesso em 2 de Ago. 2018

[4] Costa, M. S.; Allevato, N. S. G. A escrita de (futuros) Professores de Matemática na Resolução de um Problema sobre o Volume do Cilindro. Revista Educação em Questão (Online), Natal, v. 49, p. 127-152. Disponível em: <http://www.periodicos.ufrn.br/educacaoemquestao/article/view/5907/4710 >. Acesso em 28. ago. 2018.

[5] CNE-Resolução no. 1, de 5 de julho de 2000. Estabelece as Diretrizes Curriculares Nacionais para a Educação de Jovens e Adultos. Brasília, 2000.

[6] Dante, Luiz Roberto. Didática de resolução de problemas de Matemática. 2a ed. São Paulo: Ática. 1991.

[7] D’ambrósio, Ubiratan. Etnomatemática. Elo entre as tradições e a modernidade. Ed. Autêntica, Belo Horizonte, 2005.

[8] Fonseca, Maria C. F. R. Educação Matemática de Jovens e Adultos: especificidades, desafios e contribuições. Autêntica Editora, 2002.

[9] Freire, P. Pedagogia do Oprimido. 39. ed. Rio de Janeiro: Paz e Terra, 2005.

[10] Gadotti, M. Qualidade na educação: uma nova abordagem. São Paulo: Editora e Livraria Instituto Paulo Freire, 2010.

[11] Gadotti, M. A gestão democrática na escola para jovens e adultos: ideias para tornar a escola pública um escola de EJA. In: Encontro de Reflexão Sobre a Reestruturação e Reorientação Curricular da Educação de Jovens e Adultos. Anuais do I Encontro de Reflexão Sobre a Reestruturação e Reorientação Curricular da Educação de Jovens e Adultos, 2003B, São Paulo, 2010. Disponível em :<http://www.paulofreire.org >. Acesso em 25. Ago. 2018.

a. Kabbaz, P.; Brandalise, M. A. T. É possível aprender a metodologia da resolução de problemas num curso de licenciatura em matemática a distância? In: XI Congresso Internacional Sobre Gestão Universitária na América do Sul. Anais do XI Congresso Internacional sobre Gestão Universitária na América do Sul. Florianópolis. UFSC, 2011. Disponível: <https://www.researchgate.net/profile/Priscila_Kabbaz_Alves_Da_Costa3>. Acesso em 03. Ago. 2018.

[12] Lakatos, Eva Maria. Fundamentos de metodologia científica/ Marina de Andrade Marconi, Eva Maria Lakatos.- 7.ed.-São Paulo: Atlas, 2010.

[13] Secretaria Municipal de Educação (Manaus). Gerencia de Educação de Jovens e Adultos. Proposta Pedagógica Para o Primeiro Segmento Do Ensino Fundamental da Educação de Jovens e Adultos. Manaus: Gerência da Educação de Jovens e Adultos, 2016.143 p. 


\section{Capítulo 11}

\section{O uso de vídeo-aulas como recurso didático no ensino e aprendizagem de Cálculo Diferencial e Integral}

\section{Paulo Malicka Musiau}

Resumo: 0 ensino de Cálculo Diferencial e Integral está vinculado a diversos cursos de graduação, principalmente naqueles ligados à área de Exatas e Engenharias. 0 Cálculo se constitui em um dos temas de estudo, no ensino superior, que possui maior índice de reprovação e evasão por parte dos alunos dos cursos superiores, especialmente nas áreas de Ciências Exatas e Engenharia. Inserido neste contexto, as vídeo-aulas surge como uma estratégia pedagógica bastante utilizada no mundo contemporâneo, pois pode promover uma interação parecida com a de uma sala de aula, proporcionando um enriquecimento de experiências, sensações, emoções e atitudes do estudante, que não podem ser alcançadas em uma aula puramente expositiva. Abordar à produção audiovisual, significa também mostrar aos alunos, que o aprendizado não é tão desestimulante como vários acreditam, pois com os avanços da tecnologia, principalmente a internet, o educador não pode mais adotar uma postura de transmissor de conteúdo, mas de mediador crítico, capaz de articular os conteúdos programáticos às mídias que estão presentes no seu campo de trabalho. A inserção dessa atividade pedagógica surgiu com o objetivo de auxiliar os estudantes na disciplina de cálculo diferencial e integral, pois é alto o índice de reprovação e evasão por parte dos alunos dos cursos superiores, especialmente nas áreas de Ciências Exatas e Engenharia. Em relação aos resultados apresentados com esse recurso didático, pode-se avaliar através dos comentários dos educandos que as vídeo-aulas obteve uma boa aceitabilidade, pois os mesmo puderam estudar em diferentes ambientes, assistir várias vezes o mesmo conteúdo e assim puderam sanar suas dúvidas. Portanto, a experiência de elaboração de vídeo-aulas é vista como mecanismos de extrema importância para a renovação do contexto escolar. A relevância desse trabalho consiste, então, em enfatizar o uso de recursos tecnológicos, à medida que deixa a aula menos abstrata, mais dinâmica e significativa.

Palavras-chave: Recurso Didático, Vídeo-Aulas, Ensino-Aprendizagem, Inovação e Tecnologia. 


\section{INTRODUÇÃO}

Nas últimas décadas, vem surgindo no mundo uma nova sociedade voltada para informação e para o uso das multimídias. 0 avanço tecnológico tem modificado a forma de acesso às informações, neste sentido, as vídeo-aulas surge como um importante recurso didático no processo de ensino-aprendizagem.

0 momento atual com as exigências de uma sociedade cada dia mais complexa, implica a necessidade de se repensar o professor e as fronteiras do espaço escolar, bem como a novidade que ainda representa o uso das Tecnologias de Informação e Comunicação (TIC).

Diante desse contexto, as vídeo-aulas surge como uma estratégia pedagógica bastante utilizada no mundo contemporâneo, pois, principalmente, em seus demais estilos, pode promover uma interação parecida com a de uma sala de aula, assim torna-se de suma importância a introdução de novas metodologias de ensino, conforme esclarece Ferres (1996) dizendo que o uso do vídeo e de outras tecnologias proporciona um enriquecimento de experiências, sensações, emoções e atitudes do estudante, que não podem ser alcançadas em uma aula puramente expositiva.

Recorrer à produção audiovisual, significa também mostrar aos alunos, que o aprendizado não é tão sofrível e desestimulante como muitos acreditam, pois com os avanços da tecnologia, principalmente a internet, o professor não pode mais adotar uma postura de transmissor de conteúdo, mas de mediador crítico, capaz de articular os conteúdos programáticos às mídias que estão presentes no seu campo de trabalho.

Contudo, segundo Carli (2014), o uso do vídeo em sala de aula não deve ser encarado como uma substituição total à prática de laboratório ou de todas as demonstrações e experimentos, mas que os mesmos possam ser um complemento em tornar as aulas mais eficientes, atrativas, instrutivas e motivadoras.

A inserção dessa atividade pedagógica surgiu com o objetivo de auxiliar os estudantes na disciplina de cálculo diferencial e integral, pois é alto o índice de reprovação e evasão por parte dos alunos dos cursos superiores, especialmente nas áreas de Ciências Exatas e Engenharia. Em relação aos resultados apresentados com esse recurso didático, pode-se avaliar através dos comentários dos educandos que as vídeo-aulas obteve uma boa aceitabilidade, pois os mesmo puderam estudar em diferentes ambientes, assistir várias vezes o mesmo conteúdo e assim puderam sanar suas dúvidas.

Portanto, a experiência de elaboração de vídeo-aulas é vista como mecanismos de extrema importância para a renovação do contexto escolar. A relevância desse trabalho consiste, então, em enfatizar o uso de recursos tecnológicos, à medida que deixa a aula menos abstrata, mais dinâmica e significativa.

\section{METODOLOGIA}

Com a passar do tempo à necessidade de desenvolver e aprimorar novas técnicas de ensino, foi implantado na Faculdade Panamericana de Ji-Paraná (Unijipa), estado de Rondônia, no ano de 2016, no curso de engenharia civil, a inserção de vídeo-aulas como ferramenta metodológica para auxiliar no processo de ensino e aprendizagem da disciplina de cálculo diferencial e integral.

As atividades de gravações das aulas foram realizadas nos anos de 2016, 2017 e 2018, este não ainda não ocorreu. Contudo esse projeto foi estendido para as outras áreas do conhecimento tais como: Arquitetura, Engenharia Ambiental e Odontologia.

As atividades de gravação eram realizadas nas terças-feiras, em uma sala no próprio campus da Faculdade Panamericana de Ji-Paraná (Unijipa), estado de Rondônia, sala que foi cedida para as gravações, logo em seguida era editado o vídeo e fazia o upload para o portal de acesso aos estudantes.

Com relação ao tempo, cada vídeo aula contém uma média de cinco (5) a nove (9) minutos, e abaixo de cada vídeo o acadêmico pode baixar uma lista de exercício referente a cada vídeo e ir respondendo enquanto visualiza.

Sabe-se, então dos vários fatores que os professores enfrentam para que os alunos possam acompanhar e ter um bom desempenho na disciplina de cálculo. Assim, a inclusão dessa prática pedagógica é uma alternativa eficaz para auxiliar o estudante a sanar as possíveis dúvidas no decorrer da disciplinal 


\section{DESENVOLVIMENTO}

o Cálculo Diferencial e Integral é uma ferramenta matemática importante nos cursos de engenharias, pois possibilita o estudo e a modelagem de problemas reais das mais diversas áreas do conhecimento, mas segundo Silva (2009) o desempenho insatisfatório dos alunos nessa disciplina tem preocupado pesquisadores dessa área, com níveis altíssimos de reprovação e desistências nos cursos de Engenharias.

Em relação aos modelos tradicionais de ensinar onde se prioriza a memorização treinando o aluno a adotar certos procedimentos, os quais já são esperados pelo professor, precisa ser revisto. Pois, de acordo com Oliveira e Barros (2013), com a chegada das novas tecnologias e com o ascendente crescimento das redes sociais, o modelo atual de ensinar não é mais suficiente para motivar os alunos a compreenderem os conceitos de algumas disciplinas.

Diante dessa realidade, inserir vídeo-aulas como recurso didático para auxiliar os estudantes no desenvolvimento dessa área do conhecimento é uma estratégia relevante. Pois, segundo Clemes, Filho e Costa (2012), as vídeo-aulas podem auxiliar na carência de visualização conceitual que os alunos muitas vezes têm e na dinamização das aulas, sendo uma boa via de inserção de conhecimento.

É interessante destacar que as tecnologias, através dos inúmeros recursos midiáticos, favorecem na minimização de possíveis problemas de compreensão e desinteresse oportunizando um aprendizado real e atraente. Para Borba e Penteado (2005), a relação entre informática e educação deve ser pensada como transformadora da prática educativa.

No mundo contemporâneo há uma diversidade de metodologias que podem ser utilizadas em sala de aula, tais como as vídeo-aulas que podem servir para dinamizar as aulas de Física. Para Morin (2005), o vídeo é um recurso que impressiona alguns sentidos humanos, podendo facilitar o processo de ensinoaprendizagem.

A utilização de tecnologias da informação e comunicação como estratégia para tornar o ensino mais atraente e menos tradicional é uma realidade do mundo atual, onde segundo Marcelino Jr.et al (2004), o uso do vídeo como recurso pedagógico traz a possibilidade de utilizar não somente palavras, mas também imagens, muitas vezes bem mais atrativas do que a fala do professor, podendo trazer um impacto muito maior do que um livro ou de uma aula expositiva.

Vicentini e Domingues (2008) também divulgam que entre as várias tecnologias que se tem destacado nos últimos anos, o vídeo tem sido uma das mais populares. Entretanto, a incorporação dessa tecnologia pelas instituições de ensino e pelos professores não é tão simples quanto parece. Até hoje, grande parte dos profissionais da educação enfrenta dificuldades para empregar a tecnologia audiovisual como um recurso pedagógico.

Entretanto, conforme esclarece Dalla costa et al (2004), o vídeo, por si só, não faz nada. Dessa forma a autora acredita que para seu uso eficiente se faz necessário que este esteja intimamente ligado com a temática trabalhada, também esteja ligado a outras atividades educativas, onde assim tornará a aprendizagem mais significativa.

Contudo, os professores precisam refletir cada vez mais sobre mudanças nas práticas pedagógicas, pois, segundo Santos (2012), o modelo de aprendizagem que embasa as necessidades de nosso tempo não é mais o modelo tradicional que acredita que o aluno deve receber informações prontas e ter, como única tarefa, repeti-las na íntegra.

A proliferação das tecnologias digitais vem acentuando uma maior necessidade de um pensamento criativo. Então, é necessário que se ultrapasse o aspecto meramente instrumental, e aulas expositivas.

Por lidar com um conhecimento altamente abstrato, o ensino da matemática necessita de ferramentas que explorem e facilitem a compreensão do estudante, além de possibilitar ao professor abordagens mais criativas, assim, de acordo com Pereira (2008), os vídeos didáticos ou vídeos-aula podem auxiliar o professor nas suas aulas com um recurso didático relevante no mundo atual.

No meio educativo, é fundamental que os educadores saibam explorar e utilizar esses recursos, como uma maneira de facilitar o processo de ensino e aprendizagem.

Portanto, uma estratégia pedagógica relevante é utilizar os recursos tecnológicos, pois também pode ser uma forma eficiente para facilitar a compreensão dos conteúdos abordados em sala de aula de maneira expositiva, principalmente com as vídeo-aulas, podendo dessa maneira auxiliar os educandos no processo de ensino-aprendizagem. 


\section{RESULTADOS E DISCUSSÃO}

A ferramenta foi de suma importância, pois os acessos são constantes e razoavelmente altos, pois segundo os acadêmicos, houve mais facilidade em aprender o conteúdo, pois podemos assistir várias vezes a mesma resolução, e um outro aspecto positivo, são os exercícios resolvidos e disponibilizados no site baseados na ementa e na aula expositiva abordada pelo educador.

O número de visualizações até o respectivo momento das atividades destinadas aos estudantes é o seguinte: Estudo da Cálculo Diferencial e Integral: Seis mil novecentos e dois (6902), onde pode ser constatado nos respectivos endereços abaixo:

- www.sosengenheiro.com.br/video/integral-indefinida-por-substituicao-parte

- www.sosengenheiro.com.br/video/derivada-funcao-exponencial/

- www.sosengenheiro.com.br/video/derivada-regra-do-quociente-parte

Nas respostas dos alunos chamou a atenção, pois alguns alunos deixaram seus comentários referentes aos vídeos propostos, que se encontram abaixo.

" 0 projeto foi bastante importante, pois o conteúdo que tinha dificuldade nas aulas, através das vídeoaulas tive a oportunidade de ver e rever inúmeras vezes através dos vídeos e assim fui diminuindo as dificuldades na disciplina de cálculo" (Aluno1).

"Particularmente, achei a iniciativa de adotar nas aulas de cálculo diferencial e integral vídeo-aulas como suporte para sanar as dúvidas muito interessante, pois tenho várias dificuldades e poder assistir com calma, quantas vezes quiser, contribui muito para ter um desenvolvimento positivo no decorrer da disciplina" (Aluno2).

Em entrevista a Diretora da Faculdade Panamericana de Ji-Paraná (Unijipa) Rosângela Aparecida Silva respondeu que:

"Sem dúvidas esse é um projeto inovador, é muito gratificante este tipo de iniciativa de poder ajudar os alunos que apresentam dificuldades no processor de ensino-aprendizagem. Iremos acompanhar e contribuir no que for necessário para que não se perca este espírito de buscar estratégias pedagógicas para auxiliar nossos acadêmicos."

Analisando os comentários dos alunos observamos que essa prática pedagógica foi considerada positiva e eficaz pela maioria dos alunos.

\section{CONSIDERAÇõES FINAIS}

Podemos sintetizar que a problemática do ensino e aprendizagem do cálculo é bastante vasta a ser investigada e analisada e que sugestões de mudanças devem estar sempre presentes ao currículo da disciplina. Nesse contexto, considera-se importante a busca por novos cursos e metodologias que possam apoiar o estudo dessa disciplina.

Dessa forma, a inserção de video-aulas no processo de ensino-aprendizagem da disciplina de cálculo diferencial e integral foi bastante aceita pelos estudantes, pois os mesmo puderam estudar em diferentes ambientes, assistir várias vezes o mesmo conteúdo e assim poder sanar suas dúvidas.

0 uso e produção dos vídeos quando explorado de forma adequada torna-se uma importante ferramenta de ensino-aprendizagem, visto que contempla a construção e socialização de muitos conhecimentos.

Em relação os resultados apresentados neste trabalho, pode-se avaliar que a proposta didática, através das vídeo-aulas, teve uma boa aceitabilidade pela maioria dos alunos e notamos que são inúmeras as razões para que estratégia pedagógica seja inserida no âmbito escolar.

Portanto, a introdução de novas metodologias de ensino, onde a busca por métodos inovadores que deixem a aula menos abstrata e mais dinâmica, são pontos a serem revistados pelos educadores.Porém, temos que estar ciente que trata-se de um recurso didático para contribuir no ensino-aprendizagem, sendo importante ficar evidente que essas tecnologias não substituem o papel do professor. 


\section{REFERÊNCIAS}

[1] BORBA, Marcelo Carvalho; PENTEADO, Miriam Codoy. Informática e Educação matemática. 3르ed, 1aㅡ reimpressão. Belo Horizonte, Autêntica, 2005.

[2] CARLI, Eloir. Utilizando demonstrações em vídeo para o ensino de física térmica no ensino médio. Dissertação de Mestrado Profissional no Ensino de Física- UFRS. Porto Alegre, 2014.

[3] CLEMES, Glenda et al. Vídeo aula como estratégia de Ensino em Física. In: SIMPÓSIO DE INTEGRAÇÃO CIENTÍFICA E TECNOLÓGICA DO SUL CATARINENSE, 2012, Criciúma. Anais... Criciúma: IFSC, 2012. p. 422-431.

[4] DALlACOSTA, Adriana et.al. O Vídeo Digital e a Educação. XV Simpósio Brasileiro de Informática na Educação. 2004.

[5] FERRÉS, Joan. Vídeo e Educação. 2ª ed. Artes Médicas, 1996.

[6] MARCELINO-Jr, Cristiano de Almeida C. et al. Perfumes essências: a utilização de um vídeo na abordagem das funções orgânicas. Química Nova na Escola, v. 19, n. 1, p. 15-18, 2004.

[7] MORAN, José M. Integração das Tecnologias na Educação. Desafios da televisão e do vídeo à escola. Secretaria de Educação a Distância, SEED. 2005.

[8] OLIVEIRA, Eder D. et AL. Gaia Abstração Game: Proposta de um Jogo para Mediar o Processo de EnsinoAprendizagem do Paradigma da orientação a objetos. XII SB Games - São Paulo - SP - Brasil, outubro 16-18, 2013.

[9] PEREIRA, Marcus V. Da construção ao uso sem sala de aula de um vídeo didático de física térmica. Cadernos do Aplicação, Porto Alegre, v.21, n.2, 2008.

[10] SANTOS, Júlio César F. “O Desafio de Promover a Aprendizagem Significativa”, Disponíve<lhttp://cenfophistoria.files.wordpress.com/2012/02/texto desafio.pdf>. Acesso em: 29 de abr. 2019.

[11] SILVA, Benedito. A. Componentes do processo de ensino e aprendizagem de cálculo: saber, aluno e professor. In: Seminário Internacional de Pesquisa em Educação Matemática, 4, 2009, Brasília. Anais... Brasília: Sociedade Brasileira de EducaçãoMatemática,2009.

[12] VICENTINI, Gustavo W. et al. O uso do vídeo como instrumento didático e educativo em sala. XIX ENANGRAD. Curitiba, Pr, 01 a 03 de outubro de 2008. 


\section{Capítulo 12}

\section{Aprendizagem Matemática: Relato de experiência com utilização de resíduo do óleo de dendê}

\section{Luciano Santana de Cerqueira \\ Bianca Daéb's Seixas Almeida \\ Maise Silva}

Resumo: Neste trabalho relatamos estratégia de desenvolvimento de conteúdo matemático do conceito de frações, cálculo de porcentagem e noções de função do primeiro grau utilizando tema transversal relativo ao meio ambiente. Para a aula e estudo da matemática e problematização do conteúdo foi escolhido o tema Biomassa, centrado no azeite de dendê bastante utilizado na culinária local para fritura de comida típica regional. E muito apreciado pelos estudantes, de amplo conhecimento no contexto cultural na cidade de Salvador e no Estado da Bahia. A atividade foi desenvolvida no Colégio Estadual Deputado Rogério Rêgo no bairro de Cajazeiras. A metodologia utilizada permitiu a associação entre teoria e prática pelos estudantes permitindo aprendizagem significativa. Cerca de $75 \%$ dos estudantes participaram ativamente de todas as etapas das aulas. As soluções apresentadas pelos estudantes segundo tarefas propostas mostraram boa compreensão do conteúdo e desenvolvimento de habilidades para resolução de problemas matemáticos do conteúdo estudado. Também foi observado que o tema transversal foi discutido e houve ampliação da percepção da responsabilidade socioambiental dos estudantes. 0 presente relato corrobora dados obtidos em estudos anteriores sobre aprendizagem significativa. 0 tema Bioenergia pode ser utilizado para discutir tema transversal (meio ambiente) no currículo da disciplina matemática associado a temas matemáticos a partir de problematização de fatos e situações do cotidiano dos estudantes. ${ }^{4}$

Palavras-chave: Ensino. Meio Ambiente. Bioenergia. Aprendizagem significativa. Habilidades.

"Este artigo foi publicado pela primeira vez nos ANAIS da IV Jornada Ibero-Americana de Pesquisas em Políticas Educacionais e experiências Interdisciplinares na Educação, Salvador - Bahia."4 


\section{INTRODUÇÃO}

O estudo da Matemática é visto pelos estudantes como uma disciplina de difícil assimilação devido ao nível de abstração exigido para compreensão e acomodação de alguns conteúdos (Tomaz e David, 2013). Este fato pode estar relacionado a etapas anteriores do processo de aprendizagem ou, na maioria das vezes, a desarticulação do aprendizado matemático com fatos e o fazer cotidiano do estudante. No século XX o ensino das Ciências Naturais e Exatas tem exigido a utilização de recursos didáticos alternativos com valor significativo. Para D'Ambrósio (2012), as avaliações tradicionais tais como "provas, testes, exames e similares são erroneamente utilizadas para testar alunos, sendo mais adequado analisar os efeitos de uma aprendizagem por meio da análise de impacto social, assim como de comportamento de indivíduos e da sociedade como um todo.

Desse modo, como afirma Paulo Freire (1992), o professor precisa estar atento ao fato de que os estudantes adentram os espaços escolares com um conhecimento prévio, uma leitura de mundo que lhes ajudam nos processos de compreensão e aplicação dos novos conhecimentos. Assim, a experiência matemática não é simplesmente técnica, ela é uma linguagem, uma forma de dizer o mundo, e como tal, carrega em si as nuances culturais desse mundo diverso e plural. Desta maneira, os estudantes poderão, a partir de experiências e memória prévia, ter a oportunidade de associar o conteúdo apresentado em aula, ressignificar os temas discutidos, relacioná-los com atividades cotidianas associadas a sua cultura e seu modo de vida, por fim tornar o aprendizado temático permanente, associativo e significativo.

Trabalhos realizados por Fiorentini (2005), Santos e Melo (2016), Santos et al (2015) e D'Ambrósio (2012) relatam que para haver um bom resultado no aprendizado da matemática é importante que se processe a migração do currículo cartesiano para um currículo dinâmico que considere as experiências prévias dos estudantes e do contexto sociocultural em que vivem.

É, na perspectiva de uma pedagogia autônoma, desenvolvida por meio de um currículo dinâmico o qual contempla o contexto sócio cultural do estudante, a partir de experiências e memória prévia, ter a oportunidade de associar o conteúdo apresentado em aula, ressignificar os temas discutidos, relacioná-los com atividades cotidianas associadas a sua cultura e seu modo de vida, por fim tornar o aprendizado temático permanente, associativo e significativo.

A escolha do uso da biomassa como elemento central desta experiência pedagógica se deu pelo fato de que esta pode ser obtida de materiais como a madeira e seus resíduos, nos resíduos orgânicos agrícolas, urbanos e industriais, nos óleos vegetais, como por exemplo mamona, soja, dendê, amendoim que se constituem em recursos naturais disponíveis capazes de gerar formas mais elaboradas de energia, a exemplo dos biocombustíveis tais como o bioetanol, o biodiesel e o biogás (Cortez, Lora e Gomez, 2008; BNDES, 2008).

As diversas fontes de biomassa da matriz energética brasileira estão classificadas no grupo das energias renováveis e sua utilização, como combustível, contribui significativamente para diminuir impactos ambientais negativos, a exemplo do efeito estufa e aquecimento global.

A biomassa obtida através dos biofluidos, que são os vários tipos de óleos vegetais (Cortez, Lora e Gomez, 2008), presentes em abundância tanto nas residências, onde são utilizados no preparo das refeições das famílias, como nos estabelecimentos comerciais, a exemplo dos resíduos de óleo obtidos a partir das frituras de alimentos, apresentando-se assim como um potencial de biomassa na produção de bioenergia (biodiesel). Todavia, quando o óleo residual de fritura é descartado de forma inadequada pode representar sérios riscos à saúde do meio ambiente, bem como perdas econômicas devido ao não reaproveitamento como energia renovável e limpa.

Por isso, foi feita escolha do resíduo do óleo de dendê produzido por baianas de acarajé na fritura desses quitutes, bastante conhecidos no contexto cultural na cidade de Salvador e no Estado da Bahia para estudo do conteúdo matemático sobre frações, porcentagem e noções de função do primeiro grau e posterior problematização.

\section{METODOLOGIA}

\subsection{ONDE FOI DESENVOLVIDA A EXPERIÊNCIA DE APRENDIZAGEM?}

Este relato de experiência foi resultado do trabalho desenvolvido com os estudantes do segundo ano do Colégio Estadual Deputado Rogério Rêgo, localizado na Rua Luciano Gomes, s/n, no bairro de Jardim Cajazeiras, Salvador-Bahia. O Colégio funciona no regime de três turnos (matutino, vespertino e noturno) e 
oferece ensino no nível da Educação Fundamental (6º ao 9ำ ano), Educação de Jovens e Adultos (EJA) e o Ensino Médio (1ํㅡ a $3^{\underline{a}}$ série).

A escola tem utilizado um sistema de avaliação baseado na pedagogia do exame em que, de acordo com Luckesi (2003), o que importa são as notas. Neste tipo de prática pedagógica os estudantes são treinados para fazer provas e exames. Durante o ano, as notas normalmente vão sendo observadas e são elas que predominam: não importa como elas foram obtidas, nem por quais caminhos. São operadas e manipuladas como se nada tivessem a ver com o percurso ativo do processo de aprendizagem.

A Unidade escolar está localizada num bairro periférico da cidade e a comunidade escolar é composta por adolescentes, em sua maioria filhos de trabalhadores de baixa renda residentes nos bairros circunvizinhos.

\subsection{A ESCOLHA DO COLÉGIO E DO TEMA}

A escolha do Colégio foi definida por: a) o primeiro autor é docente do estabelecimento e ministra aulas de matemática; b) conhecimento prévio sobre o funcionamento e dinâmica da comunidade escolar e c) a expectativa, e o desejo, da equipe contribuir para o ensino e aprendizagem da matemática de maneira contextualizada e com significação.

No contexto do curso do Programa de Pós-Graduação Mestrado Profissional em Tecnologias Aplicáveis à Bioenergia, foi pensado um projeto que possibilitasse desenvolver práticas educativas associadas à matemática, alinhadas ao contexto do estudo de biomassa (bioenergia) que oportunizasse o aprendizado participativo com os estudantes envolvidos dessa disciplina.

Sendo assim, foi realizada discussão sobre a apropriação, pelas comunidades escolares, da cultura baiana relativa a comida típica conhecida como acarajé. A escolha dessa temática tornou possível discutir com os estudantes um dos temas transversais do currículo escolar, a saber, meio ambiente e sustentabilidade, com abordagem centrada nas fontes de biomassas e na matriz energética brasileira. A problematização da quantidade de óleo de dendê residual descartado pela baiana do acarajé se constituiu num caminho de aproximação entre a vivência cotidiana do estudante e a aplicação de conteúdos da matemática.

Em conversa com os estudantes, e após ampla discussão, todos concordaram que na cidade Salvador é encontrado com abundância o resíduo do óleo de dendê produzido após a fritura do bolinho de acarajé feito pelas baianas e resultou na escolha desta biomassa em conjunto com a turma como tema focal da problematização.

\subsection{PLANEJAMENTO DIDÁTICO-PEDAGÓGICO E DISCUSSÃO}

O desenvolvimento do trabalho consistiu em cinco etapas. Na primeira foram feitas observações relacionadas às questões do ensino-aprendizagem e dos processos avaliativos no componente matemática no qual o primeiro autor (LC) é professor. As observações apontaram para a necessidade do diálogo acerca das possíveis dificuldades encontrada pelos estudantes e pelo professor na sua prática docente. Assim, houve reunião com a coordenação do Colégio para proposição e desenvolvimento de atividade diferenciada na turma do 2 o ano do ensino médio, classe com 20 estudantes. Como método de proposição do diálogo optou-se pelas rodas de conversas pois, a mesma, abre espaço para que os sujeitos envolvidos no processo de ensino-aprendizagem estabeleçam espaços de diálogos e interação no contexto escolar, ampliando suas percepções acerca das limitações e das possibilidades de compreensão dos conteúdos apresentados no componente de matemática (Barbosa e Horn, 2008).

Da segunda etapa, que consistiu na realização das rodas de conversas, surgiu a necessidade de buscar práxis pedagógica que pudesse dar sentido, e significado, aos conteúdos matemáticos apresentados em sala de aula (conceito de frações, cálculo de porcentagem e noções de função do primeiro grau) reduzindo seu grau de abstração, de modo a conectá-lo ao cotidiano dos estudantes. Assim, foi proposto à turma trabalhar o tema Biomassa.

A introdução do tema transversal e a problematização contextualizada ocorreram de maneira gradativa, em cinco etapas. A etapa 1, igual a aula 1, que teve duração de três horas, consistiu em uma intervenção com objetivo de familiarizar a turma com o tema da bioenergia e biomassa e sua importância social e ambiental. Para isso, houve aula expositiva dialogada sobre definições e conceitos da bioenergia, tipos de biomassas. Também foram apresentadas imagens de locais onde os diferentes tipos de biomassas podem ser encontrados na cidade de Salvador e os tipos de energia gerada, para cada exemplo. 
Na mesma aula, foi realizada atividade comparativa e dialógica sobre energias renováveis a partir da biomassa e fontes de energias oriundas de recursos fósseis (carvão, petróleo). Depois, foram exibidos dois vídeos, um que apresentava o processo de produção do biogás e os diferentes tipos de biomassas utilizadas na produção deste tipo de combustível; e o segundo vídeo mostrava como produzir biodiesel e alguns tipos de biomassas utilizadas.

Na etapa 2 (aula 2) foi aplicado questionário para conhecer a percepção dos estudantes sobre biomassas. Em seguida, foi realizada discussão participativa de análise das questões e as diversas respostas para enriquecer o conhecimento adquirido e dirimir dúvidas.

Na etapa 3, os estudantes analisaram materiais informativos sobre matriz energética mundial e brasileira, de diversas fontes (jornais, livros, revistas), e puderam comparar os dados do Brasil em relação as fontes de energias renováveis (p. ex. Gómez et al., 2012; Lima et al, 2014). Em seguida, foi realizada segunda mostra de vídeo centrada na matriz energética da China, Estados Unidos, Japão e da Europa. Ao final da aula foi proposta atividade escrita visando consolidação e aprofundamento dos conhecimentos.

A quarta etapa foi realizada atividade prática da fritura do bolinho do acarajé na cantina do Colégio, mediada por uma baiana de acarajé. Para isso, os estudantes se organizaram em grupos e foi solicitado que tomassem notas dos produtos e processos, principalmente da quantidade do azeite do dendê utilizado, antes de depois da fritura.

Na quinta e última etapa ocorreu os desdobramentos. O professor (LC) solicitou que, de posse de suas anotações e de acordo com as orientações e conhecimentos matemáticos adquiridos, os estudantes aplicassem os dados coletados na atividade prática (fritura dos bolinhos) para: 1) Determinar a relação percentual observada entre o azeite de dendê residual, recolhido após a fritura, e o volume de azeite adicionado no início da fritura; 2) Construir uma sentença matemática, ou a lei da função, que expressasse a relação entre a grandeza $\mathrm{X}$, significando a quantidade de azeite antes da fritura, e a grandeza $Y$, representada pela quantidade de azeite residual após a fritura; 3) Construir uma tabela contendo seis (06) baianas que representassem, ou descrevessem, o azeite utilizado antes da fritura e o azeite residual após a fritura, como exemplificado na tabela 1 abaixo:

Tabela 1 - Azeite virgem e o residual produzido pelas baianas de acarajé

\begin{tabular}{|c|c|c|}
\hline Baianas & $\begin{array}{l}\text { Quantidade de azeite antes } \\
\text { da fritura (litros) }\end{array}$ & $\begin{array}{l}\text { Quantidade de azeite residual } \\
\text { produzido após fritura (litros) }\end{array}$ \\
\hline A & 5 & 3,5 \\
\hline B & 10 & 7 \\
\hline $\mathrm{C}$ & 12 & 8,4 \\
\hline $\mathrm{D}$ & 15 & 10,5 \\
\hline$E$ & 18 & 12,6 \\
\hline $\mathrm{F}$ & 20 & 14 \\
\hline
\end{tabular}

Por fim, e nesta última etapa, os estudantes foram convidados para mais uma roda de diálogos sobre suas impressões acerca do novo modo de abordagem do conteúdo da matemática relacionado ao cotidiano deles. Desse diálogo, assim como dos anteriores, foram feitos registros escritos em forma de relatos. Tais registros nos possibilitaram a escrita deste texto e as demais observações pedagógicas que lastreiam esta pesquisa.

\section{RESULTADOS E DISCUSSÃO}

A culminância do processo da aula de matemática com tema transversal relativo ao meio ambiente (biomassa), baseado em elemento cultural da culinária típica local, foi a obtenção de dados reais da quantidade do azeite antes e após a fritura do bolinho de acarajé.

Os estudantes refletiram que o resíduo de óleo de dendê (biomassa) produzido pelas baianas, diariamente, poderia ser uma oportunidade de negócio, com retorno ao sistema produtivo (com valor econômico) caso fosse reaproveitado para produção de energia. Além disso, a reciclagem do óleo impactou na mudança de percepção dos estudantes, pois sendo uma forma de contribuição social para a diminuição de impactos ambientais negativos. Nesta etapa, a discussão em grupo mostrou que a turma havia assimilado o conceito de biomassa e apresentava posicionamento crítico, responsável e cidadão. 
Foi observado que $75 \%$ da turma participou e desenvolveu todas as atividades propostas. Estes dados indicam que a utilização de referências que estão relacionadas a diversos problemas sociais e culturais vivenciados pelos estudantes, diariamente, quando utilizada como elemento provocador e motivador, contribui, de modo significativo, para o exercício de construção e desenvolvimento do raciocínio lógico e crítico.

Assim, a disciplina pode ser vista como meio de solucionar problemas diários ou como ferramenta para entender e resolver situações, ou relações de disputas, que possam ocorrer no seu entorno, no convívio social (Tomaz e David, 2013, por exemplo). Mas, em diversas escolas públicas, historicamente, o conteúdo matemático tem sido apresentado ao estudante como conteúdo abstrato, fixo e sem muitas possibilidades de construção coletiva, ou passível de manuseio dos números pela turma. E assim, nestas aulas, via de regra, a participação ativa dos estudantes não atingem números significativos no desempenho escolar e as avaliações objetivas tendem a mostrar resultados insuficiente de aprendizagem.

Segundo Ausubel, Novak e Hanesian (1980) para que a aprendizagem seja significativa, o estudante precisa ter em sua estrutura cognitiva conhecimentos prévios que irá associar ao novo cenário, conteúdo de aprendizagem. As expressões verbais utilizadas por alguns estudantes, durante a realização da atividade prática, indicam que o processo de apropriação do conteúdo matemático estava sendo associado a uma percepção crítica objetiva, a exemplo de "professor, agora deu pra entender pra que serve alguns assuntos de matemática na nossa vida..."; "foi legal, deu para perceber a matemática no meu dia a dia...". As manifestações espontâneas nos indicaram que a estratégia desenvolvida resultou em significação na aprendizagem do conteúdo matemático no qual foram abordados frações, porcentagem e noção de função do $1^{o}$ grau. Condizente com o que preconiza a teoria da aprendizagem significativa e as recomendações de Biembengut e Hein (2016).

Após a fritura dos bolinhos de acarajé, os estudantes obtiveram 3,5 litros de óleo de dendê residual. E utilizaram 5 (cinco) litros como volume inicial.

As soluções apresentadas pelos estudantes à problematização (vide descrição da tarefa proposta acima, em metodologia, na quinta aula) foram: 1) $\frac{3,5}{5}$ ou $\frac{7}{10}$, representação da fração do óleo residual de dendê sobre o total do óleo virgem; 2) 3,5:5 = 70\% , representação percentual do óleo residual de dendê sobre o total do óleo virgem; 3$) \mathrm{f}(\mathrm{x})=\frac{7}{10} X$ ou $\mathrm{y}=\frac{7}{10} X$, a lei de formação que se aproxima de uma função referente a quantidade de óleo de azeite de dendê residual produzido pelas seis baianas; 4) Construção de uma tabela demonstrando a quantidade do azeite utilizado, pelas seis baianas, antes da fritura e o azeite residual produzido após a fritura. Os estudantes também apresentaram a resolução da problematização no formato de tabela 2 como segue abaixo:

Tabela 2 - Função aproximada da quantidade residual de azeite de dendê

\begin{tabular}{|c|c|c|c|} 
Baiana & $\begin{array}{c}\text { Quantidade de } \\
\text { azeite de dendê } \\
\text { virgem (litros) }\end{array}$ & \multicolumn{2}{c|}{$Y=\frac{7}{10} X$} \\
A & 5 & $\frac{7}{10} \cdot 5=3,5$ & 3,5 \\
\hline B & 10 & $\frac{7}{10} \cdot 10=7$ & 7 \\
\hline C & 12 & $\frac{7}{10} \cdot 12=8,4$ & 8,4 \\
\hline D & 15 & $\frac{7}{10} \cdot 15=10,5$ & 10,5 \\
\hline E & 18 & $\frac{7}{10} \cdot 18=12,6$ & 12,6 \\
\hline F & 20 & $\frac{7}{10} \cdot 20=14$ & 14 \\
\hline
\end{tabular}

Poucos estudantes (cerca de 30\%) responderam a situação problema de maneira inadequada indicando bom aproveitamento da turma. A Lei de Diretrizes e Bases da Educação Nacional (Lei 9.394/96)estabelece no seu artigo 32 que "um dos objetivos da Educação Básica é a formação do cidadão mediante o desenvolvimento da capacidade de aprender, tendo como meios básicos o pleno domínio da leitura, da escrita e do cálculo; a compreensão do ambiente natural e social, do sistema político, da tecnologia, das artes e dos 
valores em que se fundamenta a sociedade." Neste sentido, é possível compreender que a Educação é um processo transformador e é instrumento de construção do indivíduo, e com o mesmo, de maneira que o indivíduo tenha condições de transformar sua realidade, e do seu próximo, em razão da observação das próprias necessidades e enquanto sujeito coletivo.

\section{CONSIDERAÇÕES FINAIS}

A maior parte, (75\%) da turma, 15 dos 20 estudantes, participou ativamente de todas as etapas das aulas e realizaram as atividades propostas.

Este relato corrobora dados obtidos em estudos sobre aprendizagem significativa. 0 tema Bioenergia pode ser utilizado para discutir tema transversal (meio ambiente) no currículo da disciplina matemática e apresentação de temas matemáticos a partir de problematização de fatos e situações do cotidiano dos estudantes.

Foi possível perceber que os estudantes se mostraram mais motivados para desenvolver problema-prática a partir do contexto sociocultural local (cozimento do bolinho do acarajé e o uso de azeite de dendê). Foi possível perceber que os estudantes se sentiram conectados com os conteúdos de matemática discutidos e relacionaram problemas do seu dia-dia. Esta percepção deve ter auxiliado na ampliação da consciência cidadã e identificação de si mesmo enquanto sujeito com responsabilidade e capacidade para contribuir no contexto onde vive.

No entanto, é necessário repetir as etapas com outros temas, como descarte de lixo, perda urbana de frutos de mangueiras, dentre outro, com melhor controle do processo de aprendizagem com avaliação comparativa sistemática entre uma aula tradicional e com estratégia problematizadora.

\section{REFERÊNCIAS}

[1] Ausubel, D. P.; Novak, J. D.; Hanesian, H. Psicologia Educacional. Tradução Eva Nick. Rio de Janeiro: 2ª edição, Interamericana 1980.

[2] Barbosa, Maria Carmem Silveira; HORN, Maria da Graça Souza. Projetos pedagógicos na educação infantil. Porto Alegre: Artmed, 2008.

[3] Biembengut, M.S.; Hein, N. Modelagem Matemática no Ensino. 5. ed., 5a reimpressão - São Paulo: Contexto, 2016.

[4] Brasil. Bioetanol de cana-de-açúcar: Energia para o desenvolvimento sustentável / organização BNDES e CGEE. - Rio de Janeiro: BNDES, 2008. 316 p.

[5] Brasil. Lei de Diretrizes e Bases da Educação Nacional do Brasil. Lei 9.394/96.

[6] Brasil. Parâmetros Curriculares Nacionais. 1997

[7] Cortez, L.A.B; Lora, E.E.S.; Gomez, E.O. (org). "Biomassa para energia”. Campinas, São Paulo. Editora da Unicamp, 2008

[8] D’ambrosio, Ubiratan. Educação Matemática da Teoria à Prática. 23ª Ed. - Campinas, SP: Papirus, 2012 Coleção Perspectivas em Educação Matemática.

[9] Fiorentini, D.. A Formação Matemática e Didático-pedagógica nas Disciplinas da Licenciatura em Matemática, Revista de Educação PUC-Campinas, Campinas, n. 18, p. 107-115, junho 2005.

[10] Freire, P. Pedagogia da Esperança: Um reencontro com a Pedagogia do Oprimido. Ed. Paz e Terra, Rio de Janeiro,1992.

[11] Gómez, JM.; Chamon, PH.; Lima, SB. Por uma Nova Ordem Energética Global? Potencialidades e Perspectivas da Questão Energética entre os Países Brics. Contexto Internacional. v. 34, no 2, p. 531-574, 2012.

[12] Luckesi, CC. Avaliação da aprendizagem na escola: reelaborando conceitos e recriando a prática. 7 ed. Salvador: Malabares Comunicação e Eventos, 2003.

[13] Lima, MTSL.; Souza, MC.; Flores, TS.; Cruz, NGS.; Diamantino, HD.; Barroso, LA.; ROCHA, BA.; Souza, RLM.; Ramos, PC.; Macedo, MHM. Sobre a Situação Energética Brasileira: De 1970 a 2030. Ciência e Natura v., p. 06-16, 2014.

[14] Santos, E.F.; Melo, K.C. A Educação Matemática e a Temática Ambiental: Construindo Conhecimento Sobre Geração de Energia com Sistema Solar Fotovoltaico, São Paulo, 13 a 16 de julho de 2016, Sociedade Brasileira de Educação Matemática - XII Encontro Nacional de Educação Matemática. 
[15] Santos, C. J. S., Brasileiro, S. G. S., Maciel, M. L. A., Souza, R. D. Ensino de Ciências: Novas abordagens metodológicas para o ensino fundamental. Remoa - v. 14, Ed. Especial UFMT, 2015, p. 217 - 227.

[16] Tomaz, V.S.; David, M.M.M.S. Interdisciplinaridade e Aprendizagem na Sala de Aula. 3a Ed - Belo Horizonte: Autêntica Editora, 2013 - Coleção Tendências em Educação Matemática. 


\section{Capítulo 13}

História da Matemática auxiliando na construção de conceitos: 0 caso dos números irracionais

\section{Vania de Moura Barbosa Duarte \\ Marcos Antonio Heleno Duarte}

Resumo: 0 presente artigo esboça considerações no tocante aos aspectos voltados à abordagem e uso da História da Matemática na construção do conceito de números irracionais, embasados nas discussões oriundas de momentos de formação continuada com um grupo de professores de matemática da Secretaria de Educação de Pernambuco. Fazendo uso de propostas e referenciais curriculares tais como: Base Curricular Comum de Pernambuco (BCC-PE), Parâmetros Curriculares de Matemática para o Ensino Fundamental e Médio (PCPE), Parâmetros Curriculares Nacionais (PCN) e Base Nacional Comum Curricular (BNCC) e, por livros didáticos de Matemática que contemplam o conceito de números irracionais.

Palavras-chave: História da matemática, Formação de professores, Propostas Curriculares. 


\section{INTRODUÇÃO}

A motivação que originou o desenvolvimento deste artigo deu-se a partir de encontros com professores de Matemática em momentos de formação continuada, nos quais tínhamos como proposta promover estudos e discussões sobre os referenciais para o ensino de Matemática e as possíveis conexões de conceitos estruturados nos eixos de Números e Operações; Álgebra e Funções; Geometria; Grandezas e Medidas; Estatística e Combinatória. No decorrer das discussões sugiram aspectos voltados às tendências atuais para o ensino de Matemática e como os referenciais explicitam a abordagem destas tendências.

Diante deste fato, foram realizadas diversas análises e discussões, sendo que neste artigo apresentamos um recorte das principais considerações traçadas com relação ao eixo Números e Operações, mais especificamente, aspectos voltados à abordagem e uso da História da Matemática na construção do conceito de números irracionais embasados em como os referenciais norteiam metodologicamente este uso.

Tendo como objetivo promover análises e discussões provenientes da abordagem apresentada em referenciais curriculares e livros didáticos sobre o uso da História da Matemática para a construção do conceito de números irracionais.

Para responder ao nosso objetivo, inicialmente apresentaremos nas nossas discussões como esta abordagem é apresentada por propostas curriculares existentes no estado de Pernambuco: na Base Curricular Comum de Pernambuco (BCC-PE) e nos Parâmetros Curriculares de Matemática para o Ensino Fundamental e Médio (PCPE); nos Parâmetros Curriculares Nacionais (PCN) e na Base Nacional Comum Curricular (BNCC), e por alguns autores de livros didáticos de Matemática que abordam o conceito de números irracionais resgatando aqui sobre à importância da presença da História da Matemática nos livros didáticos. Posteriormente apresentamos as conclusões das nossas discussões elencando os principais resultados bem como apontando a necessidade de aprofundamento em pesquisas futuras. Desta forma apresentaremos a seguir como foi estruturado no estudo.

\section{METODOLOGIA}

No intuito de atender ao objetivo previsto esta pesquisa está caracterizada num método qualitativo na tentativa de explicar as principais características expressas em referenciais curriculares e livros didáticos de Matemática do Ensino Médio sobre o uso da História da Matemática para a construção do conceito de números irracionais.

Segundo Oliveira (1999, p.117), as abordagens qualitativas facilitam descrever a complexidade de problemas e hipóteses, bem como analisar a interpretação entre varáveis, compreender e classificar determinados processos sociais, oferecer contribuições no processo das mudanças, criação ou formação de opiniões de determinados grupos e interpretação das particularidades dos comportamentos ou atitudes dos indivíduos.

Temos também nesta pesquisa um cunho bibliográfico para a qual segundo Gil (2008) é desenvolvida com base em material já elaborado, constituído principalmente de livros e documentos técnicos científicos.

Para tanto construímos e desenvolvemos duas etapas conforme descrito a seguir:

1a Etapa: Análise e discussão das inferências apresentadas em referenciais curriculares de Matemática com relação à introdução da História da Matemática como recurso metodológico;

$2^{a}$ etapa: Análise de situações apresentadas em livros didáticos de Matemática com relação à História da Matemática como recurso ao ensino dos números irracionais;

Na primeira etapa selecionamos referenciais curriculares de Matemática de Pernambuco que foram elaborados nos últimos oito anos, bem como resgatamos documentos curriculares de Matemática elaborados pelo MEC nas últimas décadas.

Na segunda etapa selecionamos três livros didáticos de Matemática do $1^{\circ}$ ano do Ensino Médio através de um levantamento do setor da reserva técnica da Secretaria de Educação de PE responsável pela escolha de livro didático. 


\section{RESULTADOS E DISCUSSÕES}

A História da Matemática é uma tendência da Educação Matemática que permite um entendimento de como se deu à construção dos conceitos no decorrer dos tempos, tornando-se um valioso instrumento para o ensino-aprendizagem da Matemática, contudo é importante destacar alguns aspectos referentes às possibilidades de suas abordagens.

Segundo Miorim (2005), para os autores dos Parâmetros Curriculares Nacionais, a História da Matemática, se tratada como um assunto específico ou conteúdo seria insuficiente para contribuir para o processo de ensino aprendizagem da matemática, contudo para alguns historiadores e investigadores o conhecimento histórico da Matemática despertaria o interesse do aluno pelo conteúdo matemático que lhe estaria sendo ensinado. Essa visão também é destacada nas Orientações Curriculares Nacionais, para a qual a utilização da História da Matemática também pode ser vista como elemento importante no processo de atribuição de significados aos conceitos matemáticos. Destaca ainda que a História da Matemática pode contribuir para que o próprio professor compreenda algumas dificuldades dos alunos, que, de certa maneira, pode refletir históricas dificuldades presentes também na construção do conhecimento matemático, por exemplo, a construção dos números irracionais.

Os mais ingênuos, contudo, acabam atribuindo à história um poder quase que mágico de modificar a atitude do aluno em relação à Matemática. Nessa visão teríamos a história como motivadora, dentro de uma concepção lúdica ou recreativa, a qual conforme destacado por Miorim (2005) tem-se se referindo ao ideário do movimento da Escola Nova:

E, por fim, com o intuito de aumentar o interesse do aluno, o curso será incidentalmente entremeado de ligeiras alusões a problemas clássicos e curiosos e aos fatos da história da matemática bem como à biografia dos grandes vultos desta ciência. (Portaria Ministerial, de 30-6-1931, apud Bicudo, 1942, p. 8)

Outra visão teria o recurso à História da Matemática como a possibilidade de mostrar ao educando que as teorias que hoje aparecem acabadas e elegantes resultaram sempre de desafios que os matemáticos enfrentaram que foram desenvolvidas com grande esforço e, quase sempre, numa ordem bem diferente daquela em que são apresentadas após todo o processo de descoberta, como também, ainda apresenta-se importante para reforçar o caráter dinâmico do conhecimento matemático e, assim, permitir que os educandos realizem conexões entre os conhecimentos. Esses aspectos são relevantes de serem destacados, pois se tratando de ensino os professores podem identificar que algumas dificuldades que surgem na sala de aula hoje já apareceram no passado, além de constatar que um resultado aparentemente simples pode ser fruto de uma evolução árdua e gradual e que a História pode evidenciar que a Matemática não se limita a um sistema de regras e verdades rígidas, mas é algo humano e envolvente, ou seja, humaniza a matemática.

Com essa última visão, podemos observar que a História da Matemática permite a contextualização do saber, mostrando que seus conceitos e algoritmos aparecem numa época histórica, dentro de um contexto social e político. Nesse sentido, a Matemática passa a ser entendida pelo educando, como um saber que tem significado, construído pelo homem para auxiliá-lo em sua prática.

Diante dessas visões, outra questão que surge, é relacionada à forma como o livro didático traz para a sala de aula contribuições históricas e em quais aspectos? Sabemos que o livro didático traz para a sala de aula mais um personagem, seu autor, que passa a estabelecer um diálogo com o professor e seus alunos. Nesse diálogo segundo a BCC-PE (p.65) o autor do texto intervêm com sua perspectiva sobre o saber a ser estudado e sobre o modo de se conseguir aprendê-lo mais eficazmente. Dessa forma, é importante destacar que o livro didático vem sendo objeto de análise promovida pelo MEC, no âmbito do Programa Nacional do Livro Didático (PNLD) de 6o a 9o ano, através da qual, podemos verificar que o mesmo trata, dentre outras análises, da que diz respeito à contextualização, a própria matemática, as práticas sociais atuais, a outras áreas de conhecimento, e a História da Matemática, apresentando análises do tipo: A História da Matemática é usada de forma significativa e coerente para iniciar o estudo de alguns conteúdos. Ou, elementos da História da Matemática são adequadamente usados como recurso didático, seja pela apresentação de algumas informações históricas, seja como apoio à compreensão de certos conteúdos, como sistema de numeração. Ou que, o recurso à História da Matemática é realizada de forma integrada coma apresentação dos conteúdos e não apenas como episódio informativo. Ou seja, que o aproveitamento de aspectos históricos para desenvolver o ensino e a aprendizagem é destaque na obra, já que ultrapassa a simples informação. 
Partindo destes aspectos os PCNs orientam que a História da Matemática pode ser utilizada como recurso no processo de ensino aprendizagem:

A História da Matemática pode oferecer uma importante contribuição ao processo de ensino e aprendizagem dessa área do conhecimento. Ao revelar a Matemática como uma criação humana, ao mostrar necessidades e preocupações de diferentes culturas, em diferentes momentos históricos, ao estabelecer comparações entre conceitos e processos matemáticos do passado e do presente, o professor cria condições para que o aluno desenvolva atitudes e valores mais favoráveis diante desse conhecimento (Parâmetros Curriculares Nacionais: Matemática/Secretaria de Educação Fundamental - Brasília : MEC/SEF, 1988. 148p.)

A Base Nacional Comum Curricular (BNCC), no tocante a Matemática, também se aproxima do Parâmetros Curriculares Nacionais (PCN), tendo em vista que esses documentos visam a construção de um referencial que oriente a prática escolar. De acordo com a BNCC (2016)

"a Matemática deve ser vista como um processo em permanente construção, como mostra a Historia da Matemática. Seu estudo não deve se reduzir a apropriação de um aglomerado de conceitos. 0 estudante deve ser motivado a, em seu percurso escolar, questionar, formular, testar e validar hipóteses, buscar contra exemplos, modelar situações, verificar a adequação da resposta a um problema, desenvolver linguagens e, como consequência, construir formas de pensar que o levem a refletir e agir de maneira critica sobre as questões com as quais ele se depara em seu cotidiano." (p.131).

Essa busca de novas perspectivas metodológicas para aperfeiçoar o processo ensino-aprendizagem, envolve a maioria dos professores, sobretudo os professores de matemática e que o uso de História da Matemática como instrumento metodológico surge como um meio adicional não apenas como motivação para criar disponibilidade ao aprendizado como também para a compreensão dos conteúdos apresentados.

Nos PCPE-Parâmetros Curriculares de Matemática de Pernambuco (2012) a perspectiva da História da Matemática na abordagem metodológica significa mais que descrever fatos ocorridos no passado ou a atuação de personagens famosos. Em primeiro lugar, é importante que as articulações da Matemática com as necessidades humanas de cada época sejam evidenciadas. Mais importante ainda, é preciso levar em conta as contribuições do processo de construção histórica dos conceitos e procedimentos matemáticos para a superação das dificuldades de aprendizagem desses conceitos em sala de aula.

Temos também de acordo com as Orientações Curriculares que ensinar as características do sistema decimal é fundamental para que os alunos avancem na aprendizagem da Matemática. Para isso, precisamos promover o uso dos números em diferentes contextos e o debate de hipóteses.

Segundo a BCC-PE (2008) a contextualização objetiva levar o aluno a estabelecer relações entre os diferentes conhecimentos com os quais ele entrará em contato, buscando, nessas relações, identificar as complementaridades, as divergências e as convergências entre ele, destacando que uma das formas mais eficazes de atribuir significado aos conceitos matemáticos é contextualizá-los no processo de evolução histórica desses conceitos. Esse enfoque nos remete a teoria das Situações Didáticas desenvolvidas por Brousseau, que parte da noção de obstáculo epistemológico criada por Bachelard, para a qual tem-se como princípio que "cada conhecimento ou saber pode ser determinado por uma situação", entendida como, uma ação entre o aluno (ou os alunos), o entorno e o professor por um problema estabelecido para a reconstrução de um conhecimento, tendo que para a situação seja solucionada, é preciso que os alunos mobilizem o conhecimento correspondente.

A BNCC (2016) destaca o cuidado com a contextualização explicitando que:

é fundamental na medida em que ela é importante que o/a estudante atribua sentido aos conceitos em jogo. Considerando que a Matemática nos oferece modelos para compreender a realidade, as situações escolares permitem envolver infinitos contextos, sejam eles oriundos de práticas sociais, de outras áreas de conhecimento ou, até mesmo contextos da própria matemática. Nunca é demais reforçar que o mais importante é que as situações permitam ao/a estudante atribuir significado aos conceitos envolvidos. (p.135-136) 
No tocante aos conjuntos numéricos a BNCC (2016) enfatiza também que o estudo das grandezas e medidas é fundamental para a discussão sobre a necessidade de ampliação dos conjuntos numéricos, principalmente dos racionais para os reais, a partir da utilização de números irracionais para a representação de medidas de segmentos incomensuráveis.

Diante desses enfoques, consideramos alguns aspectos referentes à continuidade para a consolidação dos conceitos de número irracional e de reta numérica apoiada nas ideias já iniciadas nas etapas anteriores, explicitada na BCC (2008), para o eixo de Números e Operações na etapa do ensino Médio, constituindo-se em objetivo importante a ser atingido.

Ao analisar atividades apresentadas nos livros didáticos do Ensino Médio voltadas para a construção de atividades didáticas suscitando abordagens da História da Matemática para o conceito de número irracional, observamos que a maior parte de autores dos livros analisados não lança mão desse recurso para promover a contextualização de conceitos, tornando o aluno incapaz de atribuir um significado aos conteúdos matemáticos, restringindo seu conhecimento ao aspecto operacional. Contudo neste estudo conforme observado nas orientações da BCC-PE tem-se que uma das formas mais eficazes de atribuir significado aos conceitos matemáticos é contextualizá-los no processo de evolução histórica desses conceitos.

No decorrer das análises dos livros, foi observado que o livro de matemática de Dante, 1a série, o mais adotado pelos professores, segundo o levantamento realizado através do setor da reserva técnica da Secretaria de Educação de PE responsável pela escolha de livro didático, apresenta aspectos referentes a como à História da Matemática aparece dentro do contexto de ensino aprendizagem, apresentando uma introdução de elementos da História da matemática, sugerindo através de uma leitura optativa a prova de que $\sqrt{2}$ é irracional. Ao inferir esse aspecto, é possível observar que ele se propõe a fornecer ao aluno informações históricas, acrescentando mais adiante a obtenção de $\sqrt{2}$ a partir de Pitágoras, o caso, do quadrado cujo lado mede 1, no qual, calcula-se a medida da sua diagonal para posteriormente, destacar a questão da representação na reta dos números $\sqrt{2},-\sqrt{2}$ e $\sqrt{3}$ e $-\sqrt{3}$ (Ver fig. 1).

Fig. 1

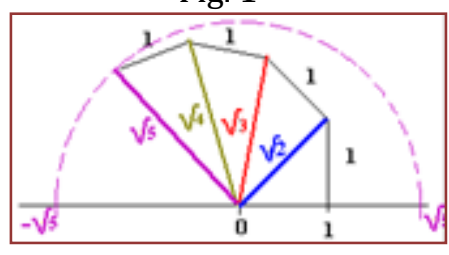

Esta análise nos remete a discussão do estudo de um recorte histórico da descoberta das grandezas irracionais, explicitado no texto A descoberta das Grandezas Irracionais de Evens, o qual destaca que essa descoberta foi uma das grandes realizações dos pitagóricos. Em particular os pitagóricos provaram que não há nenhum número racional ao qual corresponda o ponto $\mathrm{P}$ da reta no caso em que OP é igual à diagonal de um quadrado cujos lados medem uma unidade (ver fig 2).

Fig. 2

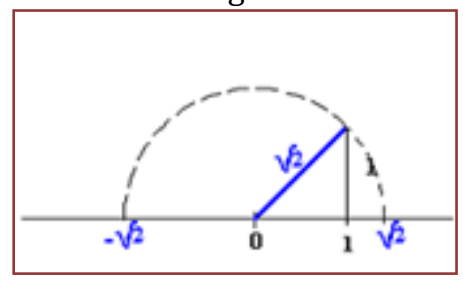

Diante disso, novos números tiveram que ser inventados para serem associados a esses pontos: e não sendo racionais, vieram a se chamar números irracionais. A descoberta desses números assinala um dos grandes marcos da história da matemática. 0 estudo desse recorte histórico referente à origem histórica da necessidade de criação dos números irracionais está ligada com dados geométricos que se podem 
concretizar no problema da medida da diagonal do quadrado, quando comparada com o seu lado, os números irracionais positivos que representam medidas de segmentos que são incomensuráveis com a unidade.

Diante desse fato podemos destacar que é possível trabalhar com esta ideia tentando expressar a medida exata de um segmento de reta, chegando à construção dos números irracionais positivos, coincidindo com a evolução histórica. Ressaltando a relevância do elemento histórico no ensino da matemática, especificamente com relação a "recorte" de situações apresentadas em livros tratando da História da Matemática (EVES e BOYER, p. ex.), ou seja, contextualizar a partir do enfoque histórico auxiliando processo de ensino e aprendizagem da matemática. Propiciando também conexões com outros eixos da matemática.

Autores de outros livros didáticos analisados com Souza (2010) e Silva (2005) apresentam pequeno esboço destes aspectos ao tratarem do conjunto dos Números Irracionais conforme podemos observar nos extratos dos livros abaixo

Extrato 1: Souza (2010)

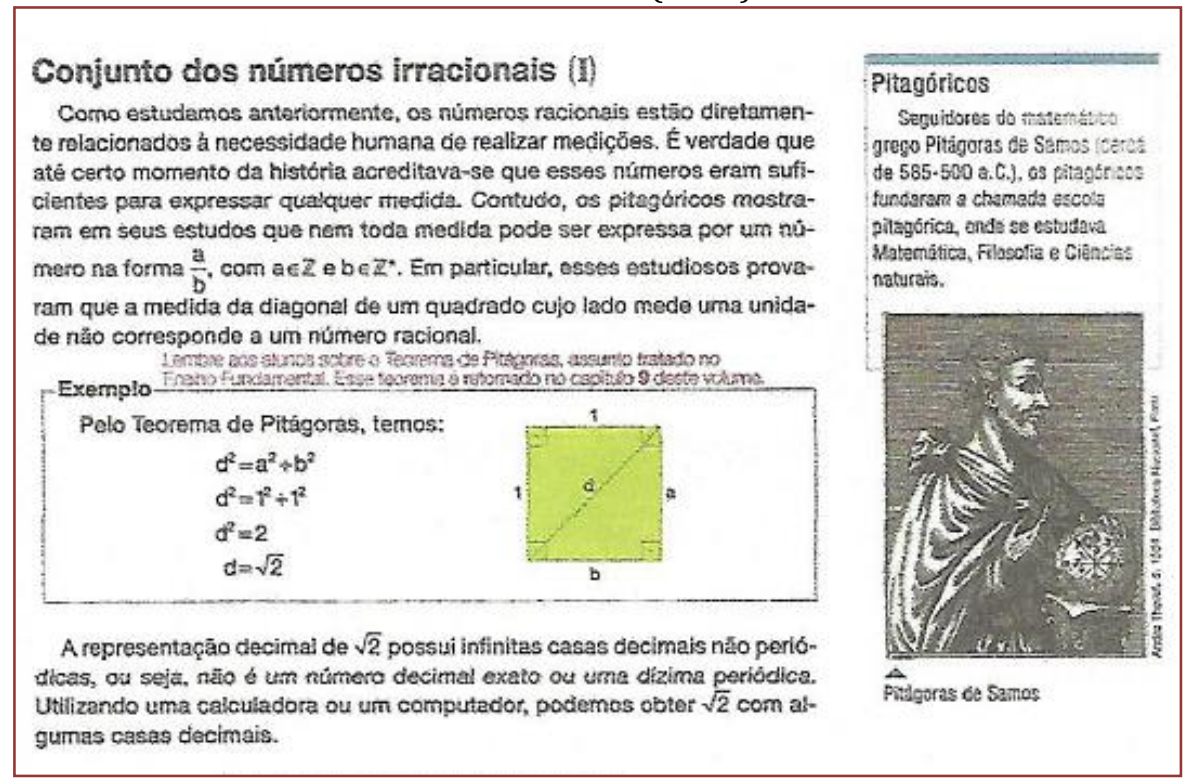

Extrato 2: Silva (2005)

\section{Conjanto $\pi_{R}$ dos misneros imacionats}

Os números racionais mä́o solacionanm muitos problemas envolvendo a Geornetrì e a

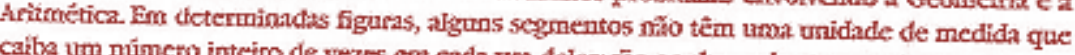
caiba um número inteiro de vezes en cada um dejes; siāo os chamados segmentos incomersur-

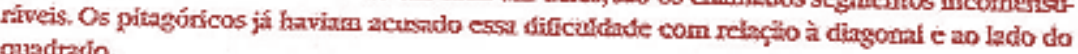
quadialo.

Excemplificartio, para un quadrado de lado $\ell=1$ e diagonal d, temos:

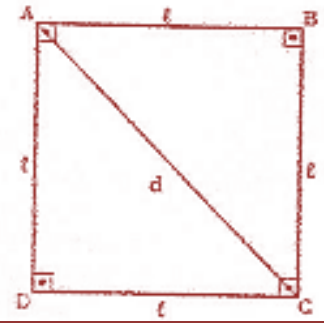

Aplicando o teorena de Pitigoras no trilingulo ABC, obtemos:

$\mathbb{d}^{2}=1^{2}+1^{2}$

$d^{2}=2$

$\mathrm{d}=\sqrt{2}=1,4142 \ldots \in Q$ 
Podemos destacar de acordo com os extratos 1 e 2 , que os autores tentam utilizar o recurso à História da Matemática de forma integrada coma apresentação dos conteúdos e não apenas como episódio informativo contudo ainda de forma muito breve. No caso do recorte histórico, existe a possibilidade de conexões do eixo numérico com os eixos geométricos envolvendo conceitos como triângulos, teorema de Pitágoras, lugar geométrico, retas paralelas e perpendiculares, ângulos e o eixo das grandezas e medidas.

\section{CONCLUSÕES}

A questão que fica é a de que as formas de apropriação da importância da História da Matemática nas práticas pedagógicas merecem ser cada vez mais serem enfatizadas nas investigações acadêmicas e nos momentos de formações continuadas com os professores quando tratar de Educação Matemática.

Considerando-se as orientações explicitadas nos documentos curriculares de matemática que a construção progressiva dos números naturais, racionais, irracionais, negativos e imaginários ao longo da história é uma fonte importante para a didática atual desses conceitos.

\section{REFERÊNCIAS}

[1] Brasil. Secretaria de Educacao Infantil E Fundamental. Guia de Livros Didáticos 2005. V. 3: Matemática/ Brasília: Ministério da Educação, 2005.

[2] ___ Base Nacional Comum Curricular- MEC 2 $2^{\text {a }}$ versão revista/Abril 2016

[3] Boyer. Carl B. História da Matemática. Editora Edgard Blücher Ltda, 2ª edição. São Paulo, 1996.

[4] Brousseau. Guy. Introdução ao Estudo das Situações Didáticas. Editora Ática. São Paulo, 2008.

[5] dante, Luiz Roberto. Coleção Matemática. 1aㅗ série. Editora Ática. São Paulo, 2008.

[6] Eves. Howard. Introdução à História da Matemática. Editora Unicamp. Campinas. SP. 2008.

[7] Gil, Antônio Carlos. Como elaborar projeto de pesquisa. 4⿳亠丷a Edição. São Paulo. Atlas, 2008.

[8] Miorim. Maria Ângela. Miguel. Antonio. História na Educação Matemática. Propostas e Desafios. Coleção Tendências em Educação matemática. Autêntica. Belo Horizonte. 2005

[9] Oliveira, Sílvio Luiz de. Tratado de Metodologia científica: projetos de pesquisas, TGI, Tcc, Monografias, Dissertações e Teses. São Paulo: Pioneira, 1999, 320 p.

[10] Parâmetros Curriculares Nacionais: Matemática. Secretaria de

[11] Educação Fundamental. Brasília: MEC/SEF, 1988.

[12] Pernambuco. Secretaria de Educação Base Curricular Comum para as Redes Públicas de Ensino de Pernambuco: matemática / Secretaria de Educação. - Recife: SE. 2008.

[13] Secretaria de Educação Parâmetros Curriculares de Matemática para o Ensino Fundamental e Médio / Secretaria de Educação. - Recife: SE. 2012.

[14] Silva, Cláudio Xavier da; Benigno Barreto Filho- 2aa ed renov- São Paulo: FTD, 2005- Coleção matemática aula por aula. Vol 1 Ensino Médio

[15] Souza, Joamir Roberto de. Novo olhar matemática- 1 ed.- São Paulo: FTD, 2010. Coleção Novo Olhar; v.1 


\section{Capítulo 14}

Dominó de Frações: Uma ferramenta para o ensino de frações

\section{Jean Oliveira da Silva}

Hailson da Costa Trindade

Francklim Sideney Vidal de Santana

Thamy Saraiva Alves

Resumo: 0 presente artigo busca demostrar a importância do conhecimento de fração para o cotidiano dos alunos e assim para o desenvolvimento matemático, aponto de estimular os alunos na aprendizagem de frações de uma maneira mais lúdica através do jogo dominó de frações, mostrando aos educadores e os educandos que por meio de material concreto e ludicidade são primordiais para o ensino e aprendizagem de fração, especificamente o jogo "Dominó de Fração" ao ensino de Fração no 5o ano, na Escola Municipal de Ensino Fundamental Prof. a Ilta Maria, na cidade de Igarapé Açu - PA. 0 aporte teórico se alicerça nos autores Struik (1989); Nunes \& Bryant (1997); Boyer (2012/1996); Oliveira (2007); Brenelli (2008), e outros que dizem que o desenvolvimento do conceito de fração é preciso o reconhecimento de seu uso em diversas situações e em diferentes contextos, trazendo uma proposta metodológica uma reflexão no sentido de que o conhecimento de fração, seja significativo em dinâmica e atividades em sala de aula, sendo o discente estimulado pela cooperação e não pela coação. A relevância do artigo, prediz com intuito de contribuir para o ensino e aprendizagem de Frações, utilizando o jogo "dominó de frações" como ferramenta metodológica na prática de ensino aprendizagem em sala de aula.

Palavras chave: Frações, Jogos de aprendizagem, Aprendizagem. 


\section{INTRODUÇÃO}

Existem processos que estão relacionados com o fato do ser humano viver em sociedade, em grupos e em culturas. Com relação ao processo cultural, podemos pensar na questão dos problemas motivadores no ensino da matemática e em suas próprias necessidades intelectuais e materiais. Estes dois aspectos, o material e o intelectual ajudam a entender o sentido do conhecimento matemático produzido por uma sociedade e o uso desse conhecimento no cotidiano.

Os professores e alunos devem tomar consciência e valorizar os processos da matemática e o que podemos tirar dela para ser usado no nosso dia a dia, assim, torna-se mais fácil saber que a matemática serve para resolver vários tipos de problemas. Se o professor não considerar tal aspecto importante, certamente causará alguns transtornos para o processo de ensino e aprendizado. No entanto, é perceptível que o ensino da matemática é ensinado por muitos professores de forma mecanizada, gerando um atraso na aprendizagem dos educandos.

Este artigo versa a intensão dos autores em buscar um ensino diferenciado com vistas a uma aprendizagem significativa, quando consabido que as maiorias das pessoas já possuem uma barreira, quando se trata de qualquer assunto relacionado com a matemática, justamente por pensarem todo conteúdo dessa disciplina é difícil.

Essa presente constatação nos motivou em pesquisar sobre um assunto de matemática muito presente no cotidiano do aluno, que é a FRAÇÃO. Diante dessa problemática, temos como objetivo geral demostrar a importância do conhecimento de fração para o cotidiano dos alunos e assim para o desenvolvimento matemático, por meio da apresentação do jogo "DOMINÓ DE FRAÇõES" para resolução de problemas fracionários, visto que os discentes têm dificuldade em operacionalizar situações nos conteúdos a presença das frações.

Destarte, que as atividades em sala de aula, quando se refere a fração, é considerado uma barreira entre o aluno e a própria matemática, trazendo muitas vezes de casa, o medo pela matemática, a qual o professor tem que desconstruir esse paradigma hereditário, promovendo métodos ou estratégias de didáticas voltada para o ensino prazeroso, surgindo dessa perspectiva a ideia dos jogos de aprendizagem, nesse caso, dominó de frações: uma ferramenta para o ensino de frações, que segundo Henrique et al (2015), a introdução dos jogos matemáticos como estratégia de ensino e aprendizagem na sala de aula é um recurso pedagógico que apresenta excelentes resultados, pois desenvolve a criatividade, o raciocínio lógico, possibilita a elaboração de estratégias por meio de uma matemática prazerosa e quebra da monotonia das aulas, além de promover interação social entre os alunos. Sendo assim, o jogo ajuda os alunos a lidar com situações-problema dando a eles oportunidade de pensar e agir por si mesmos, e faz com que o aluno pense e raciocine (FONSECA et al, 2014).

É perceptível que Fração é uma temática vista como uma grande dificuldade encontrada pelos educandos na compreensão do conceito para resoluções de atividades. Pois o conceito espontâneo da criança vem inicialmente do sociocultural, é na escola com a ajuda do professor que a criança aprimora esse conceito científico. Por isso o professor tem um papel fundamental, isto é, o docente é o mediador de conhecimento, que vai usar métodos no aperfeiçoamento cognitivo do educando. Trabalhar esta temática na instituição de ensino, é imprescindível, porque nos leva a refletir que Fração está presente no cotidiano das pessoas, pois precisamos compreender as questões que nos rodeiam no ambiente em que estamos inseridos.

Mediante ao exposto, a pesquisa teve como aporte teórico, os autores; Struik (1989); Nunes \& Bryant (1997); Boyer (1996); Oliveira (2007); Henrique (2014); Fonseca (2015), entre outros, que buscam na linguagem especifica da matemática, exercer a influencia na construção do pensamento, no raciocínio e na resolução de problemas matemáticos do dia a dia, ressaltando que a matemática tem um papel fundamental na formação de um cidadão critico e criativo, pois fomenta ferramentas que permitem desenvolver estratégias, enfrentar desafios e explicar resultados por meio de iniciativas pessoais e trabalhos coletivos.

Entretanto, a metodologia usada, foi de abordagem qualitativa e quantitativa, além de um levantamento bibliográfico a respeito do tema, elencando que os jogos de aprendizagem, a ludicidade proporcionam o conhecimento de forma prazerosa, ou seja, satisfatória, trazendo possibilidades de fixação do conteúdo, estimulando os alunos na aprendizagem de frações de uma maneira mais lúdica por meio de material concreto e ludicidade que são importantes para o ensino e aprendizagem de fração, especificamente o jogo "Dominó de Fração" ao ensino de Fração que foi aplicado a turma de 5o ano da Escola Municipal de Ensino Fundamental Prof. ․ Ilta Maria, na cidade de Igarapé Açu - no Estado do Pará. 
A praticidade do jogo "Domino de Fração" desenvolvido em atividades na sala de aula, em grupos, buscando assim a socialização ao abordarmos o estudo das frações com uso do jogo, propunha ensino por meio do lúdico e a aprendizagem ocorria contemplando todos os participantes em atividade no jogo proposto. Assim, este artigo foi desenvolvido no intuito de contribuir para o ensino e aprendizagem de Frações. Utilizando como objeto metodológico o jogo "dominó de frações" no qual busca auxiliar no ensino de frações, estimulando o conhecimento de tal temática para a construção do conhecimento.

\section{O PROCESSO DE ENSINO E APRENDIZAGEM DA MATEMÁTICA}

Hoje, a Matemática é usada para modelar, descrever, e resolver/solucionar problemas nas diversas áreas da atividade humana, visto que a importância da matemática não se limite somente a isso, abarcando que seu ensino pode e deve ser feito utilizando várias facetas, o que inclui os desafios matemáticos, as curiosidades matemáticas, a História da Matemática, dentre outros aspectos. Segundo as Diretrizes Curriculares da Educação Básica de Matemática (DCEs), o objetivo da aprendizagem da Matemática é assim registrado:

A aprendizagem da Matemática consiste em criar estratégias que possibilitam ao aluno atribuir sentido e construir significado às ideias matemáticas, de modo a tornar-se capaz de estabelecer relações, justificar, analisar, discutir e criar. Desse modo, supera o ensino baseado apenas em desenvolver habilidades, como calcular e resolver problemas ou fixar conceitos pela memorização ou listas de exercícios (PARANÁ, 2008, p.45).

Nessa perspectiva, a relevancia da Matemática no currículo escolar é destacada quanto ao papel que desenvolve o professor em sala de aula, que perpassa pela visão de educador, de estimulador, construindo as condições ideais aos seus propósitos e ao planejamento pedagógico, mediante diretrizes que ampliem os conhecimentos de mundo, em associação com os conteúdos escolares, "vendo o sujeito histórico, inserido no mundo, visando sempre ao seu crescimento" (ALVES, 2007, p.22).

Assim, Santos (2014), afirma que a função do professor é ser mediador entre o conhecimento e o aluno. No pressuposto, o docente precisa interferir o mínimo possível no processo de aquisição do conhecimento e dar oportunidade ao discente de desenvolver seus próprios conceitos, deduzir fórmulas e evoluir seu raciocínio lógico, propiciando que reflita sobre sua maneira de pensar e crie mecanismo que facilitem cada vez mais seu aprendizado.

Entretanto, Santos, (2014, p.27), fomenta que um jogo possui um objetivo em um contexto específico, a sua utilização em sala de aula tem finalidades para além da ideia original do jogo, no qual se apresenta como um produtivo facilitador da aprendizagem, desenvolvendo competências como o raciocínio, a experimentação, a reflexão, o levantamento de hipóteses, e a própria avaliação, em associação com a criação da autonomia, do aumento da autoestima e da prática da socialização

Nesse contexto, o processo de ensino e aprendizagem da matemática, destaca o papel do professor mediante ao ensino da matemática e a conduta do aluno perante adquirir conceitos matemáticos.

\subsection{O PROFESSOR, O ALUNO E A MATEMÁTICA.}

O professor tem o papel de protagonista no processo de ensino e aprendizagem, uma vez que, é ele que tem contato com a criança buscando instigar o educando a querer a aprender. Para que o aluno possa aprender é essencial que os assuntos matemáticos sejam menos formais, pois facilitariam na aprendizagem. É de responsabilidade da comunidade escolar transformar o saber abstrato em saber escolar, também não se esquecendo do contexto em que esse aluno está inserido.

0 ensino de matemática, na maioria das vezes, é discriminado como sendo centrado em si mesmo, pois o mesmo não explora outras áreas de conhecimento. É necessário ressaltar que o problema não está presente só na matemática, quando falamos de processo de ensino e aprendizagem, há um fator muito importante à formação do docente, se a matemática não é bem aceita por determinados educandos é porque muitos professores não receberam uma formação adequada para trabalhar tal disciplina.

Sabemos que o processo de ensino-aprendizagem de frações ainda é visto como um desafio, pois docentes têm dificuldades com o processo de ensino de modo que este se revele em aprendizagem, e para os alunos esse conhecimento é considerado complicado porque pode trazer dificuldades para a aprendizagem deste e de outros conteúdos de matemática na continuidade dos estudos. Para Sanches \& Santos (2011), esse 
estado de compreensão conceitual de fração não se limita aos educandos do ensino fundamental, mas de uma forma geral, no que ressalta Fornari \& Massa (2014) ressaltam que ao considerar as dificuldades enfrentadas por boa parte dos alunos no aprendizado da Matemática, principalmente quando se refere ao conteúdo de frações, os materiais manipulativos, especialmente os jogos, colaboram muito para a construção dos conceitos, facilitando o processo de ensino e aprendizagem.

Nesse sentido, cada um tem o papel importante, tanto o docente quanto o discente contribuem para melhora o processo de ensino e aprendizagem em sala de aula.

\subsection{UM BREVE CONTEXTO HISTÓRICO DE FRAÇÃO}

Segundo Boyer (2012), não se pode afirmar nada sobre a origem da matemática, seja aritmética, seja da geometria, afinal, seu princípio é mais antigo do que a arte de escrever. Não se podem apontar épocas e datas exatas pela falta registros das civilizações antigas. Isso não é diferente com as frações. Berlingoff \& Gouvêa (2010) dizem que as frações fazem parte da matemática há 4 mil anos ou mais. Mas não é possível precisar quando elas surgiram ou quem as descobriu, novamente porque os registros são poucos e talvez as primeiras ideias sobre frações nem tenham sido registradas por falta de meios para fazer isso.

A noção de número está presente desde muito cedo na história nas mais variedades de atividade. Essa noção de número só veio a ter seu êxito com o desenvolvimento da linguagem, sobre isto Boyer (2012, p. 3), afirma:

O homem difere dos outros animais de modo mais acentuado pela sua linguagem, cujo desenvolvimento foi essencial para que surgisse o pensamento matemático abstrato, no entanto palavras que exprimem ideias numéricas aparecem lentamente. Sinais par números provavelmente precederam as palavras para números, pois é mais fácil fazer incisões num bastão do que estabelecer uma frase bem modulada para identificar número. (Boyer,2012, p. 3)

De maneira intuitiva que surgiu a noção de número natural por meio do "princípio da correspondência biunívoca", onde o homem relacionava um determinado objeto com algo que determina sua existência.

Um dos primeiros registros que temos notícia sobre frações foram encontradas em pesquisas arqueológicas que comprovam sua existência há milhares de anos, no antigo Egito, quando esta civilização teve a necessidade de contar e medir terras, colheitas, líquidos, tecidos e tudo isso, motivando a um mecanismo numérico que pudesse realizar tal contagem e medida com rapidez e eficiência, que culminou para o estudo e desenvolvimento daquilo que compreendemos hoje como frações.

\subsection{O ENSINO DE FRAÇÕES}

0 ensino de frações deve ser iniciado nas escolas brasileiras, segundo Base Nacional Comum Curricular (BNCC), a partir do segundo ciclo do ensino fundamental (4ํ e 5o anos). 0 ensino de frações é um processo complicado e este é agravado quando os educandos transferem as propriedades dos números naturais para as frações. Segundo Nunes e Bryant (1997), "os alunos parecem ter uma compreensão completa das frações, utilizam de termos corretos, resolvem alguns problemas, mas diversos aspectos cruciais das frações ainda lhes fogem".

É perceptível que os alunos não se interagem com frações fora da sala de aula em relação com os números naturais. Sendo assim pouca praticada no cotidiano assim levando ao esquecimento. Diante as dificuldades, é notório que o ensino e aprendizagem de frações é vista como um obstáculo presente para professores e alunos no Brasil. Nesse sentido o ensino de frações mesma estudada no ensino fundamental menor poucas pessoas sabem fazer cálculos envolvendo frações.

As frações representam um primeiro passo dos alunos do ensino fundamental com os números racionais, pois resolver questões de fração o aluno cria abstrações da qual passa por outros conhecimentos como: sistema de numeração, conjunto de números naturais, expressões numéricas, múltiplos e divisores de um número, noções de estatística, conjunto dos números racionais para que os mesmos lhe permitam ter a noção para interpretar representações fracionarias.

A partir da necessidade da aprendizagem de frações, percebemos que existe uma carência muito grande de recursos metodológicos para auxiliar o professor e aluno no processo de ensino e aprendizagem, diante 
dessa problemática no próximo capítulo veremos a importância de inserir um objeto concreto: o jogo "dominó de frações", no qual se pergunta: Em que medida o jogo "dominó de frações" contribui para ensino frações?

\subsection{O MATERIAL LÚDICO NO ENSINO DAS FRAÇÕES}

A matemática em geral, veio ao longo do tempo se tornando uma das matérias mais complicadas de serem desenvolvidas nas escolas, devido a possuir conteúdos abstratos que se tornam trabalhosos para serem formalizados. Além desse problema, o método geralmente utilizado no ensino da matemática, tende a piorar a situação: quadro, giz, e o professor trabalhando os exercícios que não possuem conexão com a realidade dos alunos e nem os fazem entender porque precisam aprender tais conteúdos (OLIVEIRA, 2007)

A construção matemática dos números racionais é complexa, tendo a necessidade de se trabalhar com materiais concretos, possibilitando ao aluno a formação dos conceitos que se deseja passar, segundo Struik (1989), os materiais que podem ser usados nesse trabalho com frações são jogos reformulados para a matemática, softwares, e materiais básicos como: tiras de cartolina, tampinhas de garrafa, balança, botões e outros materiais auxiliares.

As habilidades que se desenvolvem quando o aluno joga, ele se depara com a necessidade de resolver problemas, instigar e descobrir a melhor jogada, refletir e analisar as regras, estabelecendo relações entre os elementos do jogo e os conceitos matemáticos. Os jogos despertam o interesse do aluno em aprender, instigam o desenvolvimento de estratégias em busca da resolução do problema.

O dominó de frações tem por objetivo fixar o conteúdo apresentado em sala de aula, desenvolver o raciocínio lógico-matemático e estratégias de jogo. As 28 peças que compõem o jogo. As 28 que compõem o jogo podem ser confeccionadas pelos próprios alunos.

Para Mendes (2009, p.51), a valorização das atividades lúdicas "no processo de construção do conhecimento matemático pelo aluno, por meio de uma prática na qual o professor utiliza jogos pedagógicos como elementos facilitadores do ato de ensinar e de aprender", têm sido uma constante na Educação. Nesse sentido, às aulas de Matemática, a utilização dos jogos possibilita uma mudança significativa no processo de ensino e aprendizagem dos conteúdos matemáticos em sala de aula.

\section{METODOLOGIA}

A metodologia desenvolvida com alunos do 5o ano do ensino fundamental, na Escola Municipal de Ensino Fundamental Prof. a Ilta Maria, na cidade de Igarapé Açu - PA, no qual utilizamos o jogo - dominó de fração, como proposta metodológica para o ensino de frações, na perspectiva de analisar o quanto o próprio contribui para seu ensino em sala de aula. As etapas perpassadas foram: Na 1a Etapa - Chegando ao local foi desenvolvido um questionamento oral aos alunos referente se eles gostam de matemática e da temática fração em que o professor chefe de classe já tinha ministrado a aula sobre o conteúdo, e a maioria respondeu que não gostam de matemática e que no ponto de vista deles a matemática é difícil e que eles aprenderam fração superficialmente, ou não aprendem. Entretanto, na 2a Etapa - Logo após, apresentaremos à turma a temática da aula: Frações, questionando-os se já ouviram tal tema, com isso, começaremos com alguns conceitos de frações de forma lúdica no quadro, mostrando a eles exemplos que fazem parte do cotidiano para uma melhor compreensão.

Após essa etapa foi feita uma socialização sobre o que os alunos tinham aprendido sobre frações naquele momento, deu se a perceber que lhes compreendiam as frações, mas os próprios não tinham conhecimentos prévios sobre: 0 que é uma fração? Como representar uma fração por meio de desenho? Logo adiante aplicamos uma prova escrita com objetivo de fazer uma análise prévia dos conhecimentos relacionados ao conteúdo de frações e em seguida mostramos o jogo, explicando como funcionam, suas regras, como a seguir.

O Jogo dominó de frações tem como objetivo contribuir o ensino de frações, pois o mesmo tem como conceituar o conteúdo de fração por meio de brincadeiras, porém o professor tem que usar sua criatividade. As primeiras partes é dividir as 28 peças entre 4 participantes daí os participantes irão entrar em consenso para um jogador sair (jogar a primeira peça).

Na 3 ${ }^{\text {a }}$ Etapa - No momento sucessivo a atividade anterior de socialização, apresentamos o jogo dominó de frações, no qual nós explicamos suas regras e como jogar, no decorrer em que eles iam jogando e 
interagindo com o jogo, fomos inserindo os conceitos e como representar as frações por meio desenho. Enquanto, que na 4a Etapa - Em seguida foi aplicada uma prova escrita com questões envolvendo operações com frações e objetivando a assimilação de conhecimento por meio do uso de material concreto o "jogo dominó de frações".

Portanto, após a realização da aula, foi elaborado um questionário de carácter qualitativo (Apêndice 1), no qual o docente falou sobre sua formação acadêmica, que a universidade contribuiu para seu ensino, principalmente o elo teoria e prática, em que a academia apenas norteia o discente acadêmico para a busca de conhecimento em sua praticidade em sala de aula. Sua familiaridade com a matemática ajuda a desenvolver o conteúdo de frações e que é útil no dia a dia dos educandos.

Nesse pressuposto, a docente afirma que o projeto pedagógico curricular da escola está adequado ao ensino de frações porque foi elaborado de acordo com a realidade do aluno e da escola utilizando o método de Paulo Freire. Ao relacionar com o conteúdo de frações afirma a professora, que alguns alunos do $5^{\circ}$ ano do ensino fundamental têm dificuldade na resolução da temática proposto, por não dominarem as operações básicas da matemática. A utilização de materiais lúdicos em suas aulas motiva e atrai os alunos e que muitos desses jogos são confeccionados na própria sala com a participação de todos, tornando a aula criativa e prazerosa para o aluno.

Para Mendes (2009, p. 25), o uso de materiais concretos e jogos no ensino da Matemática é uma alternativa didática diferenciada, muito importante para que o professor possa realizar intervenções na sala de aula. São atividades que contêm uma estrutura matemática a ser descoberta pelo aluno, na medida em que se torna agente ativo na construção do seu próprio conhecimento matemático.

Diante disso, é perceptível que o jogo “Dominó de Frações” não é utilizado na sala de aula pela professora, podendo ser um ponto de intervenção como ferramenta metodológica para o ensino de frações.

\section{RESULTADOS E DISCUSSÃO}

A partir de uma análise bibliográfica e de campo, o material concreto, especificamente o jogo "Dominó de frações" contribui de forma significativa para o ensino e aprendizagem de frações. A partir das análises das provas aplicadas com 10 (dez) questões de múltipla escolha, com 10 (dez) alunos e o uso do material concreto didático, podemos relacionar os seguintes resultados nas tabelas abaixo:

Tabela 1: Mostra a primeira prova aplicada, antes do uso do “Dominó de Frações”

\begin{tabular}{|c|c|c|}
\hline Alunos & $\begin{array}{c}\text { № de questões } \\
\text { corretas }\end{array}$ & $\begin{array}{c}\text { № de questões } \\
\text { erradas }\end{array}$ \\
\hline Aluno A & 3 & 7 \\
\hline Aluno B & 7 & 3 \\
\hline Aluno C & 8 & 2 \\
\hline Aluno D & 4 & 6 \\
\hline Aluno E & 1 & 9 \\
\hline Aluno F & 2 & 8 \\
\hline Aluno G & 5 & 5 \\
\hline Aluno $\mathrm{H}$ & 9 & 1 \\
\hline Aluno I & 2 & 8 \\
\hline Aluno J & 9 & 1 \\
\hline
\end{tabular}


Tabela 2: Mostra a segunda prova aplicada, depois do uso do “Dominó de Frações”

\begin{tabular}{|c|c|c|}
\hline Alunos & $\begin{array}{c}\text { № de questões } \\
\text { corretas }\end{array}$ & $\begin{array}{c}\text { № de questões } \\
\text { erradas }\end{array}$ \\
\hline Aluno A & 6 & 4 \\
\hline Aluno B & 9 & 1 \\
\hline Aluno C & 10 & 0 \\
\hline Aluno D & 10 & 0 \\
\hline Aluno E & 7 & 3 \\
\hline Aluno F & 7 & 3 \\
\hline Aluno G & 9 & 1 \\
\hline Aluno $\mathrm{H}$ & 10 & 0 \\
\hline Aluno I & 8 & 2 \\
\hline Aluno J & 10 & 0 \\
\hline
\end{tabular}

Fonte: TRINDADE, SILVA \& SANTANA (2019)

É notório que na primeira tabela o desempenho dos alunos não é satisfatório e já na segunda tabela o índice de aproveitamento elevou 36\% a mais em relação a anterior. 0 teórico OLIVEIRA (2007) afirma que a matemática em geral, é discriminada uma das matérias mais complicadas de serem desenvolvidas nas escolas, devido a possuir conteúdos abstratos que se tornam trabalhosos para serem formalizados. A partir da finalização da pesquisa realizada na Escola Ilta Maria, percebemos que isso é uma realidade, pois a matemática é vista por alunos como uma temática difícil de ser compreendida.

A partir da apresentação do jogo dominó de frações os alunos conseguiram compreender um pouco mais sobre os conceitos de frações, então pode concluir que os materiais concretos contribuem para o ensino de frações como afirma Struik (1989), que os alunos desenvolvem habilidades quando joga, ele se depara com a necessidade de resolver problemas, instigar e descobrir a melhor jogada, refletir e analisar as regras, estabelecendo relações entre os elementos do jogo e os conceitos matemáticos.

Os jogos despertam o interesse do aluno em aprender, instigam o desenvolvimento de estratégias em busca da resolução do problema. Assim, o dominó de frações tem por objetivo fixar o conteúdo apresentado em sala de aula, desenvolver o raciocínio lógico-matemático e estratégias de jogo. As 28 peças que compõem o jogo podem ser confeccionadas pelos próprios alunos.

Para Druzian (2007), as atividades realizadas com a utilização de jogos nas aulas de matemática como recurso metodológico representam situações muito motivadoras e de desafio, pois, possibilita no jogo, faze-lo um recurso lúdico que permite ao educador fazer a mediação entre as possibilidades dos alunos e as exigências da sala de aula, que de acordo com Fonseca et al (2014), o jogo ajuda os alunos a lidar com situações-problema, dando a eles, oportunidade de pensar e agir por si mesmos, faz com que o aluno pense, raciocine.

Entretanto, Santos (2014), a utilização dos jogos como metodologia de ensino, propicia momento de diversão e interação entre os agentes do processo ensino-aprendizagem, o desenvolvimento de capacidades logicas e argumentativas dos alunos.

\section{CONSIDERAÇÕES FINAIS}

Na realização da pesquisa de campo, observamos que a atividade dominó de frações: uma ferramenta para o ensino de frações, instigava o raciocínio lógico permitindo desenvolver estratégias de jogo. Entretanto, Druzian (2009), argumenta que o jogo é um recurso que possibilita ao educador fazer a mediação entre as possibilidades dos alunos e as exigências da sala de aula, e são muitas as contribuições que a utilização do jogo apresenta enquanto recurso didático.

Nesta perspectiva, Santana (2014), conclui que o jogo precisa cumprir algumas regras para que se tenha uma abordagem pedagógica, tais como o desafio de alcançar metas diante de um obstáculo que surge a cada momento, ser interessante o bastante para que seja trabalhado e vivenciado individualmente ou em equipe e ter objetivo que permita ao indivíduo o conhecimento e reconhecimento de si mesmo.

Destarte, que a aplicação do questionário, e do jogo como atividade em sala de aula, demonstrou que os alunos tem uma baixa habilidade em operacionalizar frações quando são expostos ao conteúdo de fração. Mas, proporcionou observar quanto a realização da atividade proposta, o interesse dos alunos em relação ao tema estudado, considerando um avanço dos alunos em relação ao conteúdo trabalhado, o qual 
possibilitou a abstração do conceito de fração, visto que a atividade escolhida para objeto de pesquisa foi o jogo "Dominó de Frações", que conforme Araújo (2000, p. 60), atividades lúdicas são atividades que geram prazer, equilíbrio emocional, levando o sujeito a autonomia sobre seus atos e pensamentos, aponto de contribuir para o desenvolvimento social, além de tornarem as aulas diferenciadas, animadas, criativas e prazerosas, facilitando assim o processo de ensino e aprendizagem dos alunos.

Segundo Brenelli (2008), a utilização do lúdico no aprendizado do aluno é importante para auxiliar na compreensão dos conceitos e ideias sobre os assuntos vistos em sala de aula, neste caso, a fração, facilitando até mesmo as tarefas escolares, no seu desenvolvimento físico, intelectual e social, o jogo vem ampliando sua importância deixando de ser um simples divertimento, tornando-se a ponte entre o contexto lúdico da sala de aula e a realidade do aluno. Nesse contexto, a relevância da pesquisa quanto ao Dominó de frações: uma ferramenta para o ensino de frações, promover aos discentes a criatividade, o domínio de si, à afirmação da personalidade, além disso, para Mota (2009, p. 47), "O jogo é facilitador da aprendizagem devido ao seu carácter motivador, é um dos recursos didáticos que podem levar os alunos a gostar mais de Matemática". Logo, temos que, através dos jogos podemos resgatar o interesse e o estimulo dos alunos em relação à matemática e seus conteúdos. Tornando-a menos complexa e mais atrativa para os mesmos.

\section{REFERÊNCIAS}

[1] Alves, E. M. S. A ludicidade e o ensino de Matemática: uma prática possível. 4. Ed. Campinas, SP: Papirus, 2007.

[2] Alves, Denis Rogério Sanches; Martenes, Adam Santos. Desafios para a construção do conhecimento de frações nas séries intermediárias do ensino fundamental. In: X Congresso Nacional de Educação - Educere. Anais. Curitiba: PUC, 2011. P. 7-10.

[3] Araújo, Iracema Rezende de Oliveira; A utilização de lúdicos para auxiliar a aprendizagem e desmistificar o ensino da matemática; Ano de 2000.

[4] Berlingoff, W.P.; Gouvêa, F.Q. A matemática através dos tempos: um guia fácil e prático para professores e entusiastas. Trad. Elza Gomide, Elena Castro. São Paulo: Edgard Blucher, 2010.

[5] Boyer, C.B. Merzbach, U. C. História da matemática. Trad. Helena Casrto. São Paulo: Blucher, 2012/1996.

[6] Brasil. Parâmetros Curriculares Nacionais: Matemática. Disponível em: Acesso em: 28. Set.2019.

[7] Brenelli, Rosely Palermo; 0 jogo como espaço para pensar: a construção de noções lógicas e aritméticas; 8Edição; Papirus, 2008;

[8] Druzian, Maria Eliana Barreto; Jogos como recurso didático no ensino aprendizagem de frações; Ano de 2009.

[9] Fonseca, Fernanda Souza. et al. 0 ensino da matemática trabalhado através de oficinas lúdicas com atividades diferenciadas e jogos. In: $2^{\circ}$ Encontro Nacional PIBID Matemática. Anais. 2014

[10] Fornari, Elaine Lima da Silva; Massa, Lindemberg Sousa. O uso do tangram no ensino de frações em turmas de 6oano. Os desafios da escola pública paranaense na perspectiva do professor. PDE. Caderno de Artigos, 2014.

[11] Mendes, I. A. Matemática e investigação em sala de aula: tecendo redes cognitivas na aprendizagem. São Paulo: Editora Livraria da Física, 2009.

[12] Mota, Paula Cristina Costa Leite de Moura; Jogos no ensino da matemática; Ano de 2009.

[13] Nunes, T.; Bryant, P. Crianças fazendo matemática, Porto Alegre, 1997.

[14] Oliveira, A.C. N. Reconstruindo Frações - o Significado Através do Lúdico. UFPel 2007.

[15] Paraná. Diretrizes Curriculares do Estado do Paraná: Matemática. Disponível em: <http://www.diaadiaeducacao.pr.gov.br/diaadia/diadia/arvosFile/diretrizes_2008/matematica pdf>. Acesso em: 29. Set.2019.

[16] Santana, Washington Jose de ET al. 0 jogo no processo de ensino-aprendizagem da matemática: um estudo das estratégias metodológicas em ludicidade no Projeto Travessia. 2014. P. 25. Dissertação (Mestrado) - Universidade Lusófona de Humanidades e Tecnologias, Instituto de Educação, Lisboa, 2014.

[17] Santos, Maria José Batista de Souza. O ensino e aprendizagem das frações utilizando materiais concretos. 2014. 13p. Monografia (Graduação em Matemática) - Universidade Estadual da Paraíba, Paraíba, 2014.

[18] Struik. D. J. História Concisa das Matemáticas. Gradativa - Publicações, L.da Lisboa. 1989. 


\section{Capítulo 15}

\section{A Teoria dos Campos Conceituais e suas implicações sobre o Campo Aditivo para o ensino de Matemática no 6a ano do Ensino Fundamental}

\section{Walisson da Silva Araújo \\ Rosimeyre Vieira da Silva}

Resumo: Considerando a situação atual do ensino, baseado no desempenho discente em testes de conhecimento na área da Matemática e em provas, observando a inadequação que reside nos processos de ensino que estão associados a metodologias que nem sempre atendem as reais necessidades dos discentes, sistematizou-se a pesquisa fundamentada na Teoria dos Campos Conceituais de Gerard Vergnaud, que é referência no âmbito da Didática Matemática. A pesquisa mapeou a literatura recorrente sobre a teoria dos Campos Conceituais e sobre o processo de ensino e aprendizagem da Matemática sustentada por autores como Vergnaud (1998, 1999), dentre outros que apoiam suas discussões relativas a aspectos da didática e ensino da Matemática como D’Amore (2007), Pais (2002), Toledo e Toledo (1997). A investigação foi realizada em duas escolas da zona rural do município de Piripiri - PI, considerando como interlocutores dois professores de Matemática de turmas de sexto ano do Ensino Fundamental. Como a finalidade de investigação ancorava-se em um estudo de natureza qualitativo-descritivo como instrumento para a coleta dos dados utilizou-se a entrevista para os professores, o questionário e aplicação de testes articulados à observação do desempenho dos alunos. Com o objetivo geral de analisar como situações didáticas fundamentadas nas Teorias dos Campos Conceituais potencializam a aprendizagem do campo aditivo, a pesquisa confirma a tese de Vergnaud de que são as situações didáticas que dão sentido aos conceitos, ou seja, um conceito não pode estar restrito a uma definição, mas conceitos são construídos pelo sujeito em um longo período conforme as situações que ele vivencia.

Palavras-chave: Teoria dos Campos Conceituais. Situações Didáticas. Campo Conceitual Aditivo. Conceitos. Matemática. 


\section{INTRODUÇÃO}

No cenário da sociedade atual, as relevantes modificações sofridas no decorrer do tempo, dentre elas o desenvolvimento tecnológico e o aprimoramento de novas maneiras de pensar os processos pedagógicos, têm possibilitado inúmeras reflexões referentes às ações dos docentes e alunos no contexto do processo ensino-aprendizagem em todos os níveis e etapas de ensino. Neste cenário, é necessário reflexões sobre o processo educativo, para o desenvolvimento de formas didáticas e metodológicas que promovam práticas pedagógicas dentro de um enfoque motivador e dinâmico, conforme o contexto na qual se desenvolvem.

Urge que a figura do professor no contexto de formação deste século esteja ancorada numa perspectiva de mediador do processo ensino-aprendizagem a partir de uma concepção de que sua prática em sala de aula tem papel fundamental no desenvolvimento intelectual do aluno, podendo ele ser o foco de crescimento ou de introspecção do mesmo quando da sua aplicação metodológica na condução da aprendizagem.

Hoje, ao fazer análises e reflexões acerca das práticas docentes, uma das maiores críticas se concentra na forma de trabalho compartimentalizado dos professores, fato muitas vezes justificado pela forma como se construiu a formação inicial do professor. Em âmbito nacional e internacional emergem discussões acerca da formação docente a partir da análise das práticas pedagógicas de professores desenvolvidas em realidades bem diferentes e algumas vezes antagônicas, que se tornam subsídios para análises e reflexões sobre o fazer docente.

As situações de análises das práticas docentes, bem como dos processos de ensino-aprendizagem são altamente significativas na formação profissional, enriquecedoras na construção dos saberes docentes e fontes para reflexão sobre o desenvolvimento de práticas de ensino que possam favorecer um processo de aprendizagem efetivo. Advogamos que as múltiplas experiências vivenciadas no processo de formação inicial, que possibilitam articulação teoria e prática, potencializam a futura atuação profissional e fortalecem a ação docente.

Assim, por compreendermos que as situações de investigação, realizadas na formação dos licenciandos de Matemática sejam momentos ricos de análise e reflexão, momentos que propiciam experiências de articulação entre teoria e prática de forma efetiva, sistematizamos uma pesquisa no final do 2017 que se estendeu durante vários meses do 2018, considerando uma proposta do Programa Institucional de Bolsas de Iniciação Científica (PIBIC), logo a seguinte pesquisa trata-se de um recorte da pesquisa. A investigação teve a finalidade principal de analisar situações metodológicas de ensino fundamentadas na Teoria dos Campos Conceituais (TCC) de Vergnaud (1990; 1993).

Considerando a Teoria dos Campos Conceituais e a investigação realizada durante o desenvolvimento da pesquisa do PIBIC, bem como a realidade atual das escolas públicas de Piripiri e, observando-se a inadequação que reside nos processos de ensino, que muito está associado às metodologias de ensino escolhidas pelos docentes, sistematizou-se uma investigação pautada no seguinte problema: Situações didáticas fundamentadas nas Teorias dos Campos Conceituais potencializam a aprendizagem do campo aditivo?

Pretende-se observar as implicações das práticas desenvolvidas à luz da Teoria dos Campos Conceituais no processo de aprendizagem, visando aquisição de informações relevantes para uma abordagem crítica das ações didáticas desenvolvidas na área da Matemática.

Como objetivo geral delineamos analisar como as situações didáticas fundamentadas na Teoria dos Campos Conceituais potencializam a aprendizagem do campo aditivo. A pesquisa estruturou-se de forma a alcançar os seguintes objetivos específicos: caracterizar as situações didáticas envolvendo o campo aditivo fundamentadas na TCC; identificar elementos e momentos que limitam ou potencializam as práticas metodológicas dos professores de Matemática com a TCC; avaliar junto aos professores as implicações das práticas com situações didáticas fundamentadas na TCC em relação a sua formação inicial e continuada.

A presente produção científica se estrutura a partir de um breve histórico sobre a teoria dos Campos Conceituais, buscando situar o leitor nas características e base conceitual que a fundamentam. No tópico sobre A didática do professor de Matemática em articulação com a Teoria dos Campos Conceituais faz-se uma análise das implicações do conhecimento sobre a teoria para condução do processo de ensino considerando o campo aditivo. No último tópico discursivo do referencial teórico faz-se uma abordagem do campo conceitual aditivo, explicitando como este se constitui e quais os cuidados que docentes devem ter em relação às estruturas aditivas e o campo conceitual. 
Na metodologia apresentamos o detalhamento quanto às bases teóricas que fundamentam a produção, os dispositivos de coleta de dados utilizados como questionários, entrevistas e testes padronizados considerando a proposta de pesquisa qualitativa desenvolvida durante a pesquisa do PIBIC.

As análises de dados foram desenvolvidas a partir da concepção de análise de conteúdos na perspectiva de Lakatos e Marconi (2007) com categorização e discussão conforme as fases de desenvolvimento da pesquisa. Nas considerações finais apresentamos nossas percepções sobre a investigação e potencial formativo da Teoria dos Campos Conceituais bem como as possíveis propostas para intervenção considerando a amostra investigada.

\section{CONSIDERAÇOES SOBRE A TEORIA DOS CAMPOS CONCEITUAIS}

Trata-se de uma teoria cognitivista que busca analisar o desenvolvimento e a aprendizagem de competências complexas dos estudantes, não é uma teoria didática. Para isso, subsidia o professor de modo que ele possa compreender os processos e as práticas de ensino que possibilitem o desencadeamento dos processos cognitivos da aprendizagem.

A Teoria dos Campos Conceituais foi proposta pelo pesquisador francês Gérard Vergnaud ${ }^{5}$, com gênese na Teoria Piagetiana, e algumas nuances observadas por Vergnaud (1996), como, por exemplo: Piaget reduz seu estudo às estruturas lógicas gerais, independentemente do conteúdo do conhecimento, o qual chamou de complexidade lógica geral. Além disso, ele não trabalhou em contextos escolares, centro de interesse de Vergnaud. O autor entende como conhecimento "tanto o saber fazer como os saberes expressos" (Vergnaud, 1996, p. 155). No saber fazer estão envolvidas as competências e as habilidades e, nestas, podem ser observados e analisados os saberes expressos pelo estudante, quando defrontado com as situações e, a partir daí, pode-se analisar a sua aprendizagem.

Para Vergnaud, Piaget deixou um legado muito importante para a educação, mas viu que ele não trabalhou suas pesquisas e fundamentos dentro da sala de aula, pois a partir do momento que nos interessamos por aquilo que se passa em sala de aula, somos obrigados a nos interessar também pelo conteúdo do conhecimento. Partindo desse pressuposto, Vergnaud sentiu-se obrigado a interessar-se por Matemática mais do que Piaget, para estudar a dificuldade apresentada pelos alunos dentro dos campos aditivos e multiplicativos. Ficando claro que as dificuldades dos alunos não são as mesmas e podem variar de um campo para o outro.

Mas ainda assim reconheceu o trabalho de Piaget dentro de sua pesquisa, destacando as ideias trabalhadas pelo mesmo como pedras angulares para a investigação da didática no ensino das Ciências e Matemática. Mas, acreditamos que a maior contribuição pode ser referenciada ao conceito de esquema, que é chave importante na pesquisa de Vergnaud.

Segundo o autor, quando confrontamos os estudantes com novas situações, eles buscam utilizar os conhecimentos adquiridos em suas experiências passadas, quando em situações mais simples e mais familiares, e tentam adaptá-las a essas novas (Vergnaud, 1988, p. 141). Nesse mesmo caminhar, buscamos compreender os conhecimentos dos professores, ao se depararem com circunstâncias que os instigam a refletir sobre a sua prática de ensino (o saber fazer) em relação a determinados conceitos matemáticos (os saberes envolvidos). É nesse momento que encontramos elementos para entender os seus conhecimentos.

Nessa visão, o autor concebe o conhecimento em Campos Conceituais, em que alguns podem ser importantes para a compreensão de outros. Dessa forma, Vergnaud (1996) considera útil falar em distintos Campos Conceituais, se eles puderem ser consistentemente descritos. Nesta perspectiva é praticamente impossível estudar as coisas separadamente e isoladas, por isso mesmo, é preciso fazer recortes considerando o todo que envolve as partes. Nesse sentido, os Campos Conceituais são unidades de estudo capazes de dar sentido aos problemas e às observações feitas em relação à conceitualização.

Para Vergnaud, um campo conceitual significa "um conjunto informal e heterogêneo de problemas, situações, conceitos, relações, conteúdos e operações de pensamento, conectados uns aos outros e, provavelmente, interligados durante o processo de aquisição (Vergnaud, 1982, p. 40).

\footnotetext{
${ }^{5}$ Gerard Vergnaud é um referencial no âmbito da Didática da Matemática. Formado em Psicologia e tendo como orientador de tese doutoral Jean Piaget, sua teoria veio a adentrar o Brasil ao fim dos anos 1980. In: Lima, Ivoneide Pinheiro [et al.]. A formação de professores de matemática sob diferentes perspectivas teóricas. Teresina: EDUFPI, 2013.
} 
Observamos que, para o autor, as ligações do conceito com seus elementos constituem o significado fundamental de um Campo Conceitual. Acreditamos que, no processo de ensino, o trabalho com o conceito precisa ser estruturado de forma que a prática de ensino contemple a variedade de situações que o envolvem. Assim, entender o conceito envolve compreensão do significado que este tem considerando os diversos contextos, dessa forma, os conceitos são construídos pela mediação do professor em estruturar situações didáticas diversas que favoreçam a internalização e compreensão do conceito.

Uma das concepções que fundamentam a teoria e das internalizações que importam ao professor de Matemática ou de outras áreas é a de que um conceito não pode se restringir a uma definição. É importante o compromisso docente em estabelecer situações diversas que possam propiciar ao aluno a vivência de uma variedade de situações correspondentes ao conceito.

Apesar de Vergnaud delimitar o campo de investigação inicialmente com um olhar especial para a Matemática, sua teoria não se limita a esta área do conhecimento, podendo ser aplicada nas diversas áreas do conhecimento. Destaca-se neste caso teóricos como Moreira (2002), Justo (2010), Braga (2006), Grings et al. (2006) dentre outros que fazem uso dessa teoria para explorar respectivamente áreas como Ensino de Ciências, Educação Física, Computação e Ensino de Física.

\section{A DIDÁTICA DO PROFESSOR DE MATEMÁTICA EM ARTICULAÇÃO COM A TEORIA DOS CAMPOS CONCEITUAIS}

Atualmente, existem inúmeras propostas de metodologias de ensino que facilitam a transmissão do conhecimento e promovem aprendizado ao aluno, mas nem sempre algumas metodologias na área da Matemática, que exigem fundamentação teórico-prática, chegam à sala de aula, em alguns casos em função da pouca ou inexistente discussão sobre estas ou pesquisas que divulguem o que realmente refletem estas teorias no Ensino de Matemática.

A falta de conhecimento tardia de alguns docentes da Matemática, sobre as várias teorias que fundamentam aspectos referentes às metodologias de ensino e didática da Matemática, tem como consequência a reprodução da sistematização e organização dos processos de ensino e aprendizagem, pois esses docentes de forma ingênua, são influenciados a um fazer docente igual ao que vivenciaram como estudantes e utilizam metodologias desligadas da atualidade e longe das propostas contemporâneas da área da Educação Matemática.

Ainda é comum, nos dias atuais, práticas de ensino em Matemática em que professores repassam os conteúdos com abordagens, práticas metodológicas e recursos pedagógicos de décadas anteriores e que não atendem às expectativas do público desse novo milênio, pois não permitem o desenvolvimento de domínios cognitivos que favoreçam ao aluno entender o significado dos conceitos, conteúdos e saberes e não promovam a compreensão para o aluno. (Nacaratto; Passos; Mengali, 2009).

Segundo Abrantes, Serrazina e Oliveira (1999, p.27):

0 professor é o elemento chave na criação do ambiente que se vive na sala de aula. Cabe-lhe a responsabilidade de propor e organizar as tarefas, realizá-las e de coordenar o desenvolvimento das atividades dos alunos, o que requer um conhecimento do conteúdo a ensinar.

O autor aponta o papel e a responsabilidade do professor no processo de construção do conhecimento e destaca que a seleção ou a opção didático- metodológica exigem conhecimento do conteúdo de ensino. Neste sentido, a discussão do conteúdo do conhecimento e a reflexão sobre a forma como se dá o seu ensino oportuniza pensar numa transformação nas metodologias dos professores, pois, é importante entender que será a experiência e o envolvimento de cada aluno com as experiências de ensino e a aprendizagem que irão determinar o quanto o objeto de estudo será ou não útil ao mesmo (Vergnaud, 1996c, p.68).

Assim, para que se efetive a aprendizagem dos conceitos matemáticos os professores devem oportunizar a vivência de experiências que desafiem os alunos a refletir e questionar os contextos de aprendizagem ao tempo em que esses docentes também se permitam refletir sobre sua ação docente.

Os professores devem organizar um ambiente favorável à aprendizagem, preparar atividades pedagógicas diferentes, utilizar diferentes recursos pedagógicos como jogos e atividades lúdicas, recursos tecnológicos, fazer uso de contextos diferentes e até outras atividades diferenciadas, estruturadas matematicamente para auxiliar a aprendizagem do aluno, através da manipulação de objetos, aplicações e discussões com o 
professor e colegas, fazendo o aluno entender a importância do conhecimento matemático e levando-o a sentir prazer em tentar resolver os problemas propostos.

A imagem negativa em relação à Matemática por parte do aluno em alguns casos, é o reflexo de aulas não concluídas, enfadonhas, repetitivas, cansativas e que tem consequências negativas para os alunos e impactam outros componentes curriculares no âmbito escolar. Professores mais entusiasmados, conseguem fazer aulas de Matemática mais convincentes, prender a atenção, ser mais ativos, positivos e sentir prazer no que fazem.

Advogamos que o envolvimento do professor na organização do trabalho pedagógico com a Matemática do sexto ao nono ano exige profundo conhecimento sobre esta área, considerando a especificidade das unidades temáticas, números, álgebra, geometria, grandezas e medidas e probabilidade e estatística propostos pela Base Nacional Comum Curricular (BNCC), e exige também fortalecimento das teorias que fundamentam os conhecimentos didático-pedagógicos, considerando diferentes aspectos como os da psicologia do desenvolvimento e da aprendizagem, filosofia e sociologia da educação, para que possa fortalecer os saberes da didática da Matemática.

A postura de mediador do professor de Matemática, considerando a Teoria dos Campos Conceituais, deve ser direcionada para que:

[...] o professor não deve pensar pelo aluno, mas possibilitar o desenvolvimento da capacidade de pensar várias possibilidades de alcançar o resultado, sem interferência direta do professor, principalmente por meio de palavras-chave para indicar as operações a serem realizadas nas situações-problemas que podem conduzir os alunos ao erro. (Reges, Sá, Silva, 2013, p. 39)

De forma geral o citado implica reconhecer que, independentemente do tipo de atividade ou estratégia de ensino que o professor escolhe para encaminhar o processo de ensino, o mais importante consiste em desafiar e acompanhar o desenvolvimento do educando, sem fornecer a resposta a priori ou modelos prescritos a serem seguidos. No tópico seguinte serão expressas as considerações sobre esta perspectiva de atuação docente, contemplando as especificidades do campo aditivo.

\subsection{A ATUAÇ̃̃O DO DOCENTE DE MATEMÁTICA E O CAMPO CONCEITUAL ADITIVO}

Para a atuação docente que favoreça o desenvolvimento das habilidades matemáticas devemos ter em mente que a compreensão dos conceitos que envolvem as operações de adição não surge a partir de uma única situação, para que tal compreensão ocorra, torna-se necessário que o indivíduo se depare com diversas e distintas situações, pois "os conceitos matemáticos traçam seus sentidos a partir de uma variedade de situações, e cada situação normalmente não pode ser analisada com a ajuda de apenas um conceito" (Magina et al., 2008, p. 8).

Se os alunos estiverem repetindo procedimentos, ou realizando o que lhes for dito para fazer, não desenvolverão estratégias de resolução, a atividade apenas se converterá em exercício repetitivo ou em execução algorítmica

O raciocínio aditivo envolve relações entre as partes e o todo, ou seja, ao somar as partes encontramos o todo, ao subtrair uma parte do todo encontramos a outra parte, ou seja, envolve ações de juntar, separar e corresponder um a um.

O campo conceitual das estruturas aditivas é o conjunto de situações que pode ser gerado por seis relações básicas: composições simples, transformações simples, composições com uma das partes desconhecidas, transformações com uma das partes desconhecidas, transformações com a parte inicial desconhecida e comparações, ou por combinações delas. O conjunto das estruturas aditivas não é homogêneo e as dificuldades se distribuem nas variadas situações.

Para o autor da TCC, a definição de um conceito está vinculada ao conjunto de situações que constituem as referências de suas diferentes propriedades e ao conjunto de esquemas utilizados pelos sujeitos nessas situações (Vergnaud, 1996a).

A ação operatória envolve a utilização de significantes explícitos (palavras, enunciados, símbolos e signos) e isso é indispensável à conceitualização o que, segundo Vergnaud (1996a) conduz a consideração de que a formação de um conceito está apoiada em um tripé de conjuntos $(S, I, R)$, no qual $S$ é um conjunto de situações que dão sentido ao conceito (a referência); $I$ é um conjunto de invariantes sobre os quais repousa a operacionalidade dos esquemas (o significado); e $R$ é um conjunto de formas que permitem 
representar simbolicamente o conceito, as suas propriedades, as situações e os procedimentos de tratamento (o significante).

Neste estudo, as situações $(S)$ envolvidas dão sentido aos conceitos do Campo Conceitual Aditivo; os invariantes operatórios $(I)$ dão significado aos procedimentos operatórios envolvidos na resolução dos problemas aditivos, representados pelos estudantes, na maioria das vezes, pelo cardinal da soma ou da subtração, os significantes $(R)$.

Refletindo sobre o campo aditivo, Vergnaud (1999) classificou em seis classes os tipos de problemas que podem ser considerados conforme esse campo e que intitulou de "relações aditivas de base". 0 Quadro 01 apresenta a explicação dos tipos de situações-problemas do campo aditivo apontando exemplos.

Quadro 01: Situações-problema do Campo Aditivo

\begin{tabular}{|c|c|c|}
\hline $\begin{array}{l}\text { Situação- } \\
\text { problema }\end{array}$ & Análise da situação-problema & Exemplo \\
\hline $\begin{array}{l}\text { Composição de } \\
\text { Quantidades }\end{array}$ & $\begin{array}{l}\text { Nesse tipo de situação trabalha-se } \\
\text { com relação parte-todo, onde há a } \\
\text { composição de duas ou mais } \\
\text { quantidades para se formar o todo, ou } \\
\text { tira-se uma parte de um todo, } \\
\text { obtendo-se a outra parte }\end{array}$ & $\begin{array}{l}\text { Regina tem } 04 \text { canetas de cor azul e duas pretas. } \\
\text { Quantas canetas tem ao todo? - Regina tem } 06 \text { canetas, } \\
\text { sendo } 04 \text { de cor azul e algumas pretas. Quantas canetas } \\
\text { pretas ela possui? }\end{array}$ \\
\hline $\begin{array}{l}\text { Transformação de } \\
\text { Quantidades }\end{array}$ & $\begin{array}{l}\text { São problemas que permitem } \\
\text { relacionar um estado inicial, seguindo } \\
\text { de uma transformação para obter um } \\
\text { estado final }\end{array}$ & $\begin{array}{l}\text { Bia tinha } 03 \text { bonecas, ganhou mais } 02 \text { de sua mãe no } \\
\text { seu aniversário. Quantas bonecas ele tem agora? Bia } \\
\text { tinha algumas bonecas, ganhou mais } 02 \text {, de aniversário, } \\
\text { de sua mãe. Agora Bia ficou com } 05 \text { bonecas. Quantas } \\
\text { ela possuía antes do aniversário? }\end{array}$ \\
\hline $\begin{array}{l}\text { Comparação de } \\
\text { Quantidades }\end{array}$ & $\begin{array}{l}\text { Fazem sempre uma relação entre } \\
\text { duas partes, comparando-as. As } \\
\text { partes são denominadas referente e } \\
\text { referido, existindo uma relação fixa } \\
\text { entre elas. }\end{array}$ & $\begin{array}{l}\text { Cláudio tem } 06 \text { bolinhas de gude e Pedro tem } 04 \text { a mais } \\
\text { do que ele. Quantas bolinhas de gude tem Pedro? Ao fim } \\
\text { do jogo de bolas de gude, Pedro ficou com } 10 \text { bolinhas. } \\
\text { Sabendo que Cláudio tem } 04 \text { a menos do que Pedro, } \\
\text { quantas bolinhas tem Cláudio? Cláudio tem } 06 \text { bolinhas } \\
\text { de gude e Pedro tem } 10 \text {. Quem dos dois possui mais } \\
\text { bolinhas? Quantas a mais? }\end{array}$ \\
\hline $\begin{array}{l}\text { Comparação de } \\
\text { Transformações }\end{array}$ & $\begin{array}{l}\text { Nesse tipo de situação, demonstram- } \\
\text { se as transformaçôes sucessivas e } \\
\text { busca-se o resultado dessas, que será } \\
\text { calculado com base na composição. }\end{array}$ & $\begin{array}{l}\text { No aniversário de Júlia, ela ganhou } 08 \text { livros de seus } \\
\text { colegas de classe. Ao chegar em casa, seus pais lhe } \\
\text { deram } 04 \text { livros. Quantos livros Júlia ganhou no seu } \\
\text { aniversário? M No dia das crianças, Vivi ganhou de seus } \\
\text { pais duas bonecas. Ao chegar à casa da sua avó, ela } \\
\text { ganhou mais uma. Quantas bonecas Vivi ganhou no dia } \\
\text { das crianças? }\end{array}$ \\
\hline $\begin{array}{l}\text { Composição de } \\
\text { Relações }\end{array}$ & $\begin{array}{l}\text { Nessa situação, realiza-se uma } \\
\text { composição de duas quantidades que } \\
\text { são dadas em uma relação estática. }\end{array}$ & $\begin{array}{l}\text { Danilo deve } 12 \text { reais a Ricardo e } 08 \text { reais a Pedro. } \\
\text { Quantos reais Danilo deve no total? }\end{array}$ \\
\hline $\begin{array}{l}\text { Transformação de } \\
\text { Relações }\end{array}$ & $\begin{array}{l}\text { É dada uma relação e objetiva-se } \\
\text { descobrir a nova, originada da } \\
\text { transformação da relação estática. }\end{array}$ & $\begin{array}{l}\text { Roberta tinha } 16 \text { chaveiros a mais que Fernando. Ele } \\
\text { ganhou } 05 \text { chaveiros. Quantos chaveiros Roberta tem a } \\
\text { mais do que Fernando? }\end{array}$ \\
\hline
\end{tabular}

Fonte: Adaptado de Reges, Sá e Silva (2013)

Essa variedade de situações com diferentes graus de complexidade exige que o professor tenha clareza das dificuldades presentes nos problemas que propõe, para não ficar repetindo situações que exigem do aluno sempre o mesmo raciocínio. Cabe a ele propor uma ação planejada que oportunize a vivência de um conjunto de situações que envolvam conceitos de naturezas distintas para evitar o insucesso e potencializar a compreensão de seus alunos na resolução deles.

À luz da Teoria dos Campos Conceituais, compreende-se que a variedade de operações pertencentes a uma determinada categoria estudada, possibilita ao professor direcionar os alunos a situações-problema em diversas complexidades e contextualidades. 


\section{PERCURSO METODOLÓGICO DA INVESTIGAÇ̃̃O}

A revisão da literatura evidenciou que esse é um tema atual, embora seja uma teoria que surgiu ainda no século passado, e que, analisando os resultados encontrados em diferentes contextos e regiões do país, é possível verificar que são muito semelhantes aos que foram evidenciados nesta pesquisa, fato que se torna preocupante, considerando a dimensão do nosso país.

Quase sempre os alunos tendem a manifestar atitudes afetivas menos favoráveis em relação à Matemática à medida que aumentam os anos de escolarização, pois o percentual de crianças que terminam o ensino fundamental com algum déficit em relação as operações básicas da Matemática e/ou interpretação textual de questões contextualizadas é recorrente e preocupante a todos os professores da área das ciências exatas. Assim, optamos por investigar o $6^{\circ}$ ano do ensino fundamental por ser um ano escolar de transição dentro do nível de ensino fundamental e porque na maioria dos livros didáticos adotados neste ano letivo tem-se o campo aditivo como objeto de conhecimento na primeira unidade.

A pesquisa foi realizada em duas escolas da zona rural do município de Piripiri-PI, considerando como interlocutores dois professores de Matemática e duas turmas de sexto ano do Ensino Fundamental.

Dentre os diversos procedimentos operacionais que servem para mediar de forma prática a realização das pesquisas, fizemos a opção por dispositivos adequados à natureza do problema de pesquisa. Como a finalidade de investigação ancorava-se em um estudo de natureza qualitativa descritiva, como instrumento para a coleta dos dados, utilizamos o questionário com perguntas abertas para os alunos, a entrevista com professores e aplicação de testes articulados à observação do desempenho dos alunos.

Segundo Gil (2007, p. 125), o questionário é o “[...] conjunto de questões sistematicamente articuladas, que se destinam a levantar informações escritas por parte dos sujeitos pesquisados, com vistas a conhecer a opinião dos mesmos sobre os assuntos em estudo".

A entrevista e a observação utilizadas como técnica para coleta de dados, ao mesmo tempo em que valorizam a presença do investigador, também dão espaço para que o sujeito investigado tenha liberdade de participar da pesquisa e enriquecê-la. As entrevistas com os professores das duas turmas no decorrer da pesquisa a partir de um roteiro semiestruturado, teve a finalidade de melhor compreendermos os colaboradores e o locus da pesquisa.

Assim, a seguir descrevemos nosso percurso investigativo, contudo, é oportuno destacar que as fases da pesquisa não aconteceram necessariamente em sequência de ações e sim num processo de articulação entre as fases.

FASE 01 DA PESQUISA: Aplicação de testes e dispositivos de coleta de dados como Questionário, Entrevista e Observação.

TESTE 1: aplicado com os alunos no primeiro dia da pesquisa, antes de qualquer conceito acerca do conhecimento sobre campo aditivo. Teve dois objetivos: (a) levantar os modelos explicativos dos estudantes e (b) iniciar uma discussão acerca do campo aditivo.

TESTE 2: aplicado ao final do estudo do campo aditivo e das sequências de ensino realizadas pelo professor da turma.

FASE 02 DA PESQUISA: Análise dos dados da pesquisa

Neste sentido, após a coleta de dados, Lakatos e Marconi (2007) sugerem a classificação deles de forma sistemática, através de seleção (exame minucioso dos dados), codificação (técnica operacional de categorização) e tabulação (disposição dos dados de forma a verificar as inter-relações). Esta classificação possibilita maior clareza e organização na última etapa da pesquisa, que é a elaboração do texto do artigo.

A organização e a análise dos dados foram realizadas mediante a construção de instrumentos para tabulação de dados, como fichas de interpretação analítica em que se volta à coleta de informações sobre um ou vários casos particularizados fazendo interpretações. No processo de análise recorremos de início aos testes aplicados com alunos do $6^{\circ}$ ano e somente depois consideramos os dados das entrevistas e questionários.

A pesquisa mapeou a literatura recorrente referenciada na temática, para isso, a discussão sobre a teoria dos Campos Conceituais e sobre o processo de ensino e atuação docente em Matemática foi fundamentada em D'Amore (2007), Pais (2002), Toledo e Toledo (1997) e Vergnaud (1999, 1990, 1993,1998), dentre outros que apoiam suas discussões quanto aos aspectos como formação e didática do ensino da Matemática. 
A etapa de exercícios é realizada com utilização do livro didático com questões em que são explorados diversos exercícios para fixação do conhecimento. As correções, segundo os docentes, quase sempre são coletivas em função da quantidade de alunos por turma.

Compreendemos que a organização da aula adotada pelos docentes favorece ao aluno entender alguns conceitos do campo aditivo, porém, este tipo de metodologias não favorece o desenvolvimento de domínios cognitivos mais complexos como compreensão, análise e síntese das estruturas do campo aditivo, pois a simples aplicação dos conceitos através de exercícios não possibilita o desenvolvimento desses esquemas cognitivos de ordem complexa.

Argumentamos em relação a esta dificuldade ou impossibilidade de desenvolvimento cognitivo das ideias associadas ao campo aditivo, porque observamos tanto através das entrevistas quanto das observações do livro didático e do desempenho dos alunos que, ao trabalhar o campo aditivo a ação docente se restringiu ao desenvolvimento das ideias de juntar quantidades e acrescentar uma quantidade a outra já existente. Compreendemos que desenvolver domínios cognitivos de compreensão, análise e síntese sobre conceitos do campo aditivo envolve trabalho com situações didáticas que propiciem a apropriação de conceitos como composição de quantidades, comparação de quantidades, comparação de transformações, composição de relações, transformação de relações e outras que permeiam o campo aditivo; trabalho com conceitos através de situações problemas de forma sistemática e dinâmica, pois as diversidades e intensidades das atividades e situações fortalecerão a aprendizagem.

É importante destacar que, no 6o no do Ensino Fundamental da escola investigada, o campo aditivo foi explorado no primeiro bimestre, correspondendo a unidade 02 do livro didático adotado. A Imagem 02 apresenta a única seção do livro adotado que traz exercícios e problemas envolvendo o campo aditivo.

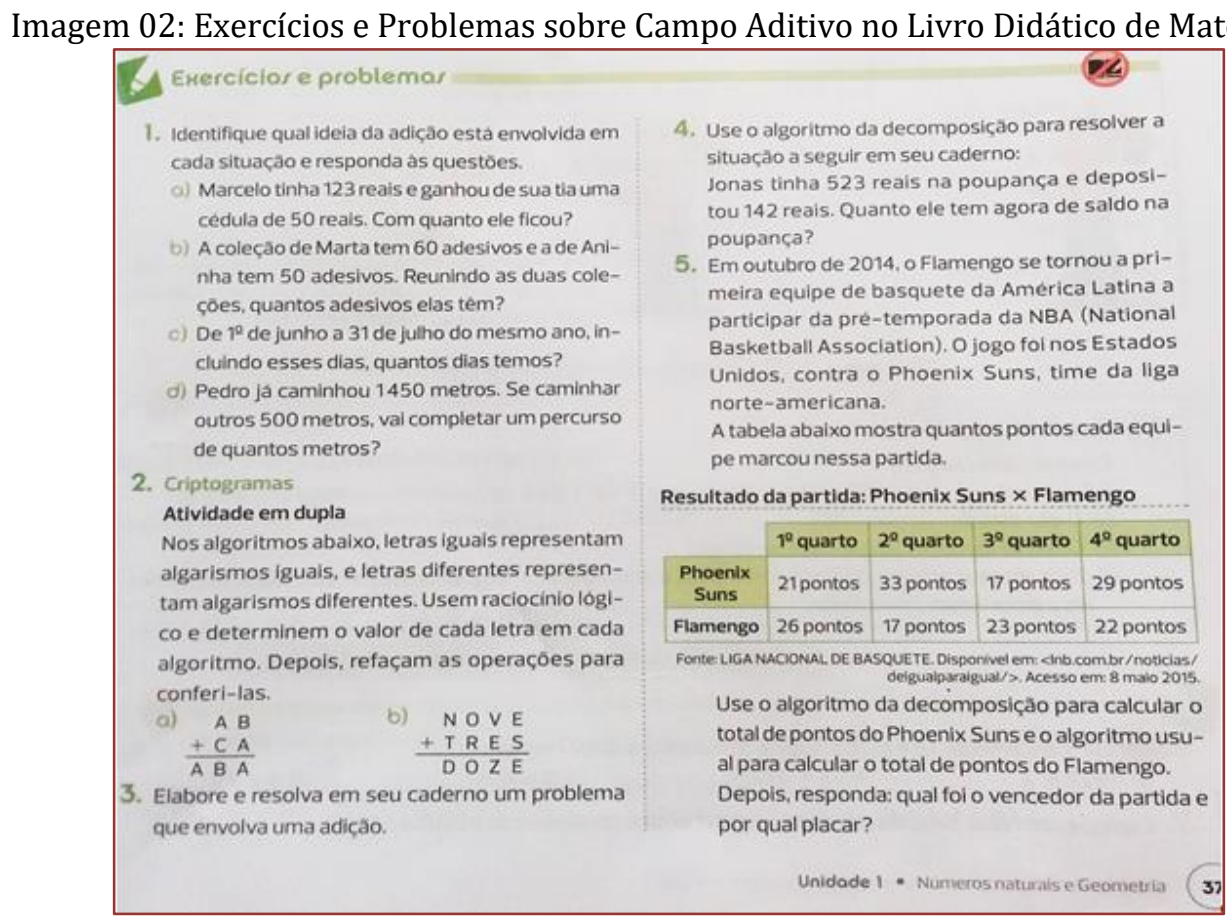

Fonte: Livro Didático de Matemática (Dante, 2015)

Observamos que se o professor ficar restrito ao livro didático, não vai conseguir favorecer a aprendizagem dos conceitos que envolvem o campo aditivo pois são poucos exercícios e problemas para o desenvolvimento dos conceitos sobre o campo aditivo, sendo importante a complementação e exploração através de outras atividades diversificadas como listas de exercícios, jogos, atividades em grupos, resolução de situações problemas individuais e coletivas e outras estratégias didático-pedagógicas.

Em síntese, para a formação dos conceitos do campo aditivo é necessário que os alunos interajam com uma diversidade de situações didáticas que visem ao desenvolvimento e maturação de estruturas cognitivas responsáveis pela evolução do pensamento mais complexo, pois, conforme Vergnaud (1996) o conhecimento é fruto da maturação do indivíduo, de sua experiência e de sua aprendizagem. 
Considerando o objetivo de identificar elementos e momentos que limitam ou potencializam as práticas metodológicas dos professores de Matemática com a TCC, nossas análises nos permitiram sistematizar a Figura 02 que representa os aspectos limitadores e potencializadores.

Figura 02: Elementos e momentos que limitam ou potencializam as práticas metodológicas com TCC

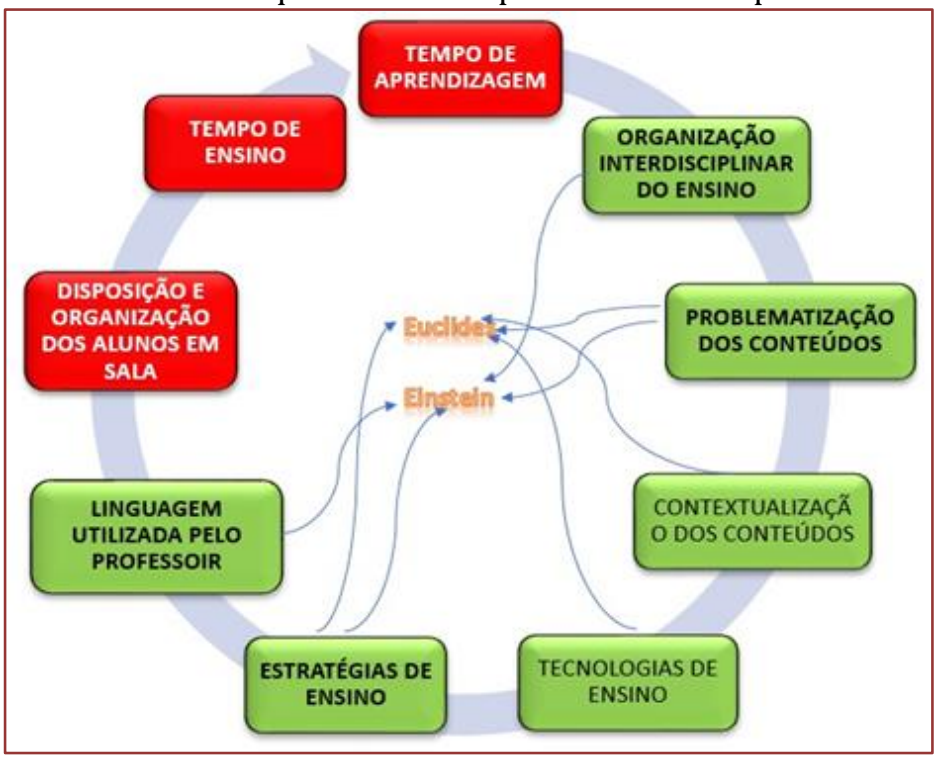

Fonte: Produzida pelo primeiro autor com dados da pesquisa

$\mathrm{Na}$ percepção dos docentes investigados, os aspectos apresentados tanto podem limitar a prática metodológica quanto potencializar, vai depender das concepções e condições de trabalho docente. Destacam como fator limitador do trabalho docente principalmente o tempo de ensino e de aprendizagem, bem como a disposição e a organização dos alunos em sala.

Quanto ao tempo de aprendizagem, consideram o fato de a maioria dos alunos apresentarem déficit de aprendizagem em relação aos saberes das quatro operações matemáticas, um fator determinante para aprendizagem da Matemática no sexto ano. Neste aspecto compreendemos que realmente seja importante que o aluno já saiba as quatro operações matemáticas ao iniciar o $6^{\circ}$ ano do Ensino Fundamental, porém, quando o conhecimento não foi apreendido, cabe ao professor tomar a decisão de desenvolver os conceitos considerando estratégias e práticas que promovam vivências com diversas situações necessárias à internalização e compreensão dos conceitos.

Apesar de elementos e momentos como recursos didáticos pedagógicos, estratégias de ensino, tecnologias de ensino, contextualização dos conteúdos, problematização dos conteúdos e organização interdisciplinar do ensino serem apontados pelos docentes, existe uma contradição entre o idealizado e o executado, visto que, no modo de organização da aula apresentada, não foi possível comprovar a utilização desses elementos na sistematização pedagógica do ensino dos docentes investigados.

Sobre a importância da contextualização dos conteúdos matemáticos, ambos concordam com a importância da contextualização em sala, enfatizado a fala do professor Euclides que diz: "além de preparar o aluno para avaliações futuras, estamos fazendo a aprendizagem ser ativa, saindo da decoreba e sim buscando o aprender", e remete às políticas de currículos que tratam a contextualização como princípio pedagógico e consideram que:

A contextualização não pode ser feita de maneira ingênua, visto que ela será fundamental para as aprendizagens a serem realizadas - o professor precisa antecipar os conteúdos que são objetos de aprendizagem. Em outras palavras, a contextualização aparece não como uma forma de "ilustrar" o enunciado de um problema, mas como uma maneira de dar sentido ao conhecimento matemático na escola. (Brasil, 1997, p. 83).

A referência acima tem uma relação direta com a TCC em sala de aula, pois muitos alunos têm dificuldade quanto ao conhecimento matemático, demonstrações, cálculos e interpretações, então a ausência de 
contextualização do conhecimento matemático pode acarretar inúmeras dificuldades futuras, incluindo lacunas no processo de compreensão da linguagem matemática.

Ao serem interrogados sobre as estratégias utilizadas em sala de aula, foi identificado um problema que não é só dos professores que contribuíram para a pesquisa, mas dos professores de Matemática de forma geral: o tempo de aula e de organização do trabalho pedagógico. Durante a formação inicial é orientado que se devem fazer aulas mais dinâmicas, mais atrativas, que prendam a atenção dos alunos, mas que não fuja do conteúdo proposto. A fala do interlocutor da pesquisa ressalta esse problema:

Por conta do tempo estar sendo corrido e por não ter feito o planejamento anual, estou explorando o método tradicional de ensino. (Professor Euclides).

Diante da resposta do professor Euclides, vemos que em meio a tantos avanços tecnológicos e nas concepções sobre ensino, o modelo de aula de alguns professores ainda continua privilegiando práticas metodológicas centralizadas no docente e apenas com a utilização de recursos como: pincel, quadro, caneta, caderno e livro.

É necessário reflexão, parar de olhar para o passado e seguir em direção à superação da escola limitada a ler, escrever, contar e receber informações de cultura geral. Para a formação dos cidadãos para o contexto atual e do futuro necessita que seja oferecido desde os primeiros anos de escolarização processo de formação que permita a construção do conhecimento a partir de uma participação mais ativa e efetiva.

Criar condições para uma participação mais ativa dos alunos, implica transformar esse "modelo tradicional", o desenvolvimento de estratégias que garantem um aprendizado maior e estejam interligadas ás situações reais.

Quanto às estratégias, ambos as utilizam para fortalecimento do campo aditivo e fazem referência a duas metodologias utilizadas em sala de aula. O Professor Euclides relatou que faz "associações com situações do cotidiano, de preferência aquelas que ele tem maior contato" enquanto o Professor Einstein explica: "Em muitos momentos das series iniciais do fundamental é importante recorrer ao ábaco, caroços de feijão, fazer uso do concreto". São esses tipos de situações didáticas que devem ser valorizadas e fortalecidas, fazendo-as estar presentes no cotidiano da sala de aula de forma sistemática e planejada.

Ao avaliar junto aos professores as implicações das práticas com situações didáticas fundamentadas na TCC em relação a sua formação inicial e continuada, verificamos que os docentes já tinham conhecimento sobre a TCC de discussões e leituras realizadas nas disciplinas cursadas na formação inicial, porém, foi possível inferir a partir dos relatos que foram conhecimentos superficiais e que ambos têm necessidades formativas diversas e entre elas apontaram a de aprofundar saberes e conhecimentos sobre as Teorias dos Campos conceituais de Vergnaud bem como de outras teorias didáticas, metodologias de ensino relacionadas a conteúdos específicos da Matemática, recursos pedagógicos.

Neste aspecto defendemos que o professor precisa sempre rever suas metodologias e inovar, considerando os resultados obtidos em sala de aula, buscando sempre fazer o processo de ensino e aprendizagem ser eficaz, pois ele é o responsável por pensar sobre o ensino e sobre o modo de ensinar. Assim, a formação continuada deve ser estimulada pelos sistemas e buscada pelos professores, pois eles precisam ser estimulados sempre a refletir sobre o uso de estratégias e metodologias diversificadas, e a ter um olhar crítico ao contexto escolar e educacional, visando alcançar sucesso no processo de ensino e aprendizagem.

\section{CONSIDERAÇÕES FINAIS}

A pesquisa desenvolvida que buscou analisar a utilização da Teoria dos Campos Conceituais no ensino da Matemática, considerando o campo aditivo conclui que são vários os condicionantes que influenciam o processo de ensino e aprendizagem, alguns internos ao trabalho da escola e outros externos, que impactam no processo de aprender os conceitos relacionados ao campo aditivo.

Realmente a diversidade de situações de ensino com as quais os alunos estejam envolvidos durante o processo de construção do conhecimento favorece o fortalecimento das estruturas cognitivas e consequentemente da compreensão sobre os conceitos do campo. Porém, é necessário que o professor esteja ciente sobre o processo de conhecer e aprender o conhecimento por parte do aluno, assim, exige fortalecimento de seus saberes docentes da especificidade da área de atuação, dos pedagógicos e das teorias que fundamentam os processos de aprendizagem. 
Dentre os dilemas que envolvem o tema em discussão, que acreditamos ser o ponto inicial de reflexão, encontra-se o de compreender a raiz do problema e, em nossa perspectiva, o primeiro passo para estudar o progressivo domínio de um campo conceitual por parte do aluno é identificar e classificar situações diversas que podem compor um campo conceitual. Assim, é necessário também entender que o domínio de certos campos conceituais é um programa de longo prazo que exige tempo e dedicação no processo de sistematização metodológica do ensino, com observações constantes do progresso da aprendizagem, identificando as lacunas formativas.

Assim, defendemos que investir na formação docente torna-se urgente como meio de compreender os processos de ensinar e aprender Matemática, deve ser ponto de atenção contínua na agenda das políticas para melhoria da aprendizagem no atual contexto.

\section{REFERÊNCIAS}

[1] Abrantes, P.; Serrazina, L.; Oliveira, I. A Matemática na Educação Básica: reflexão participada sobre os currículos do ensino básico. Lisboa: Ministério da Educação / Departamento da Educação Básica, 1999.

[2] Braga. M. M. Design de software educacional baseada na Teoria dos Campos Conceituais. Dissertação. Mestrado em Ciências da Computação. UFPE - RECIFE. 2006.

[3] Brasil. Lei no 9.394, de 20 de dezembro de 1996. Diretrizes e Bases da Educação Nacional. Brasília, DF. 1996

[4] D’amore, Bruno. Elementos de Didática da Matemática. São Paulo: Editora Livraria da Física, 2007.

[5] Dante, Luiz Roberto. Projeto Teláris: Matemática Ensino Fundamental 2. 2. ed. São Paulo: Ática, 2015, p. 61,

62.

[6] Grings, E. T. O. et al. Possíveis indicadores de invariantes operatórios apresentados por estudantes em conceitos de termodinâmica. Revista Brasileira de Ensino de Física. v. 28o. № 4. p. 463-47. 2006.

[7] Justo, A. S. Teoria dos Campos Conceituais e a Educação Física: uma contribuição pedagógica. Trabalho de Conclusão de Curso. Universidade Estadual de Londrina. Londrina, 2010.

[8] Lakatos. Eva Maria, MARCONI. Marina de Andrade. In: Metodologia do trabalho científico: procedimentos básicos, pesquisa bibliográfica, projeto e relatório, publicações e trabalhos científicos. 6. ed. São Paulo: Atlas, 2007

[9] Lima, Ivoneide Pinheiro. et al. A formação de professores de Matemática sob diferentes perspectivas teóricas. Teresina. EDUFPI, 2013.

[10] Magina, S. et al. Repensando adição e subtração: contribuições da teoria dos campos conceituais. 3. ed - São Paulo: PROEM, 2008.

[11] Moreira, M. A. A Teoria dos Campos Conceituais de Vergnaud, o Ensino de Ciência e a pesquisa nessa área. Investigações no Ensino de Ciências, v. 7, no 1, p. 7 - 29. 2002.

[12] Nacarato, A. M.; Mengali, B. L. S.; Passos, C. L. B. A matemática nos anos iniciais do ensino fundamental: tecendo fios do ensinar e do aprender. Belo Horizonte: Autêntica, 2009.

[13] Pais, Luiz Carlos. Didática da Matemática: uma análise da influência francesa. 2 ed. Belo Horizonte: Autêntica, 2002.

[14] Toledo, Marilia, Toledo, Mauro. Didática da Matemática. São Paulo: FTD, 1997.

[15] Vergnaud, G. A comprehensive theory of representation for mathematics Education. Journal of Mathematical Behavior, v. 2, n. 17, p. 167-181, 1998.

[16] Vergnaud, G. A formação de competências profissionais. Revista do GEEMPA, Porto Alegre, n.4, p.63-70, jul., 1996c.

[17] Vergnaud, G. A Teoria dos Campos Conceituais. In: Brun, Jean (Org.). Didáctica das Matemáticas. Tradução de Maria José Figueiredo. Lisboa: Instituto Piaget, 1996a, p.155 - 191.

[18] Vergnaud, G. A trama dos Campos Conceituais na construção dos conhecimentos. Revista do GEEMPA, Porto Alegre, n.4, p.9-20, julho, 1996b.

[19] Vergnaud, G. et al. Epistemology and psychology of mathematics education. In : Nesher, P. ; Kilpatrick, J. (Eds.) Mathematics and cognition: A research synthesis by International Group for the Psychology of Mathematics Education. Cambridge: Cambridge University Press, 1990.

[20] Vergnaud, G. Gérard Vergnaud: "Todos perdem quando a pesquisa não é colocada em prática". (2008) disponível no link: <https://www.passeidireto.com/arquivo/6640821/gerard-vergnaud-entevista>. 
[21] Vergnaud, G. La théorie des champs conceptuels. Recherches en didactique des Mathématiques, v. 10, n. 23, p. 133-170, 1990.

[22] Vergnaud, G. Teoria dos campos conceituais. In: Nasser, L. (Ed.). Seminário Internacional de Educação Matemática, 1, 1993, Rio de Janeiro. Anais do Seminário Internacional de Educação Matemática. p. 1-26.

[23] Vergnaud, G. Teoria dos campos conceituais. In: NASSER, L. (Ed.). Seminário Internacional DE Educação Matemática, 1, 1993, Rio de Janeiro. Anais do Semiário Internacional de Educação Matemática. p. 1-26. 


\section{Capítulo 16}

\section{Avaliação da aprendizagem na proposta de investigação matemática com o geogebra}

\section{Maxwell Gonçalves Araújo \\ Duelci Aparecido de Freitas Vaz \\ Elivanete Alves de Jesus \\ Paulo César de Jesus Cruvinel}

Resumo: Apresentamos uma experiência sobre o processo de avaliação em educação Matemática, vivenciada num curso de licenciatura em Matemática. Representa uma proposta de intervenção relacionada a inserção de tecnologias na educação Matemática, numa metodologia denominada de Investigação Matemática com o GeoGebra, que pode ser resumida em seis etapas: experimentar, conjecturar, formalizar, generalizar, monitorar e avaliar. A ideia principal consiste em desenvolver processos investigativos sobre problemas matemáticos e, no desenrolar da atividade, avaliar o desenvolvimento do aluno. Inicialmente é proposto um problema investigativo como arranque da aula. A partir disso, realizamos com o aluno experimentações utilizando o software GeoGebra que, com a mediação pedagógica do professor, possibilitará suscitar conjecturas a serem formalizadas. Em seguida, para validar ou formalizar as conjecturas, o escolar, juntamente com o professor, deverá procurar argumentos adequados de acordo com o desenvolvimento cognitivo dos estudantes. A generalização consiste em investigar se 0 problema pode ser generalizado, uma característica do pensamento matemático. 0 processo avaliativo perpassa todo processo desde o princípio, iniciando com um monitoramento de toda atividade, com a finalidade de garantir que todos os escolares participem do processo e possibilite uma aprendizagem mais eficaz. No final, os alunos devem apresentar como atividade avaliativa um projeto de intervenção com a finalidade de percebermos seu nível cognitivo com relação a aprendizagem de conteúdos matemáticos e com relação a proposta metodológica. Como resultados exitosos, temos percebido a adesão de alunos e professores da Instituição, constatados na produção monográfica e artigos publicados por eles.

Palavras-chave: Avaliação, Aprendizagem, Investigação, Matemática, GeoGebra. 


\section{INTRODUÇÃO}

Um dos problemas encontrados na formação de professores está relacionado a didática. Se por um lado, nos cursos de formação de professores de pedagogia, é dada especial atenção à formação geral em didática, por outro é disponibilizado pouca atenção às didáticas específicas, como por exemplo, o tempo dedicado a formação metodológica para ensino de Matemática ou ciências em geral. Pesquisadores apontam que isso passa a ser um fato que vem prejudicando a formação dos escolares, principalmente nas séries iniciais (LIBÂNEO, 2010, p. 581).

Já nos cursos de formação específica, como Matemática, Física, Química, e outros, é dada pouca ênfase a didática e muita ênfase ao saber específico. Sem qualquer sombra de dúvida, o foco no conteúdo, sem a devida articulação deste com outras áreas e com a didática, tem sido apontado como um grande problema para o ensino-aprendizagem.

Nos cursos de formação de professores de Matemática impera um sincretismo metodológico, com predominância do ensino formal, onde professores descrevem e transmitem ao escolar o aspecto científico, com pouca interação entre aluno e objeto de conhecimento. Há também a presença de um tecnicismo exacerbado, com ênfase nas técnicas de cálculo em detrimento do entendimento delas. Por fim, temos que ressaltar a presença de um certo "construtivismo", onde não se consegue perceber a filiação metodológica do professor, impera um emaranhado de concepções construtivistas que acabam não resultando em nenhuma, uma vez que muitos aportes teóricos são antagônicos.

No que tange a metodologias que propiciam a inserção de tecnologias no ensino-aprendizagem da Matemática temos complicações maiores, uma vez que é impossível pensar a inserção de tecnologias na educação Matemática, sem pensar sua complexidade, predominando concepções teóricas variadas sobre o tema. Há sempre uma tentativa de adaptar as tecnologias a maneira própria do professor e isso o permite adaptar as tecnologias ao seu método tradicional. Chamamos isso de inovação conservadora, devido ao fato de que o professor usa tecnologias modernas para reproduzir o mesmo método.

A grande pergunta a ser feita é: "De que forma poderemos utilizar tecnologias modernas de forma inovadora ou como podemos aplicar teorias de conhecimento, matemática e tecnologias numa didática?".

Nesta direção apresentamos a Investigação Matemática com o GeoGebra procurando integrar vários aspectos relacionados, com o foco na aprendizagem de conteúdos de Matemática. Pensamos as tecnologias como ferramentas uteis para que o escolar tenha um alto nível de relacionamento com o saber. As teorias de conhecimento nos dão a base de que para um ensino-aprendizagem eficaz é necessário um planejamento em termos de ações e tarefas, de tal modo que, ao final da atividade, o aluno compreenda os aspectos centrais do conceito e saiba aplicá-lo em situações diversas.

Na concepção de uma metodologia de ensino-aprendizagem de Matemática integrada as tecnologias, levamos em consideração, vários aspectos do saber matemático, das teorias de conhecimento articuladas em uma didática. Com relação ao saber matemático, consideramos sua historicidade, ou seja, os objetos matemáticos são conceituados ao longo da história e, portanto, possuem um dinamismo e estão relacionados com outros conceitos, e possuem movimento histórico sofrendo evoluções contínuas. Também com relação a esses aspectos históricos levamos em consideração que conceitos emergem dentro de uma certa demanda social, de necessidades específicas, e podem ter diferentes significados ao longo da história. Na articulação entre tecnologias e educação matemática, é necessário realizar um movimento no sentido de trazer a tona o conhecimento histórico produzido e isso pode ser realizado através de um problema gerador, introduzindo como arranque da aula.

Assumimos que a função principal da escola é fazer com que o escolar se aproprie da experiência científica da humanidade, se inteirando, portanto, de seu arsenal cultural (ciências, éticas, artes, etc.). Assim, se faz necessário que os conhecimentos historicamente produzidos façam parte da formação do aluno. Dessa maneira, o professor deve planejar o ensino de modo que o aluno tenha um contato direto com objeto, mas de forma que, ao cumprir etapas desse planejamento, ele vá se apropriando do saber gradativamente. De certa forma, o professor planeja a atividade de tal modo que ao realizá-la, o estudante percebe o caminho histórico percorrido pelo cientista que determinou a formação daquele conceito.

Nossa proposta metodológica para o ensino-aprendizagem da Matemática foi denominada de Investigação Matemática com o GeoGebra. Pressupõe um trabalho com o aluno, no qual participa ativamente do processo de apropriação do conhecimento. Numa fase inicial da aula, os alunos, em um laboratório de ensino, são colocados em atividade com a finalidade de apropriação das ferramentas fundamentais dos softwares. Isso permite ao aluno ter agilidade em construir figuras, em escrever equações na janela algébrica, em movimentar os objetos. 
O software GeoGebra é gratuito e está disponível em múltiplas plataformas. Trabalha todo o conteúdo de Matemática do ensino fundamental e superior. Existe, na rede de Internet, uma vasta produção de trabalhos em todos os níveis de ensino (monografias de final de curso, dissertações de mestrado, teses de doutorado, artigos científicos e livros), além do mais, é fácil encontrar tutoriais explicativos de como realizar construções diversas. 0 próprio software disponibiliza uma página onde disponibiliza trabalhos de pesquisadores do mundo todo.

É uma ferramenta importante, pois possibilita ao escolar, a partir de uma mediação pedagógica, a construção de objetos matemáticos dinâmicos, o que implica numa maturidade do pensamento matemático do aluno, uma vez que nele se pode testar hipóteses e ainda trabalhar álgebra e geometria ao mesmo tempo, na mesma tela, possibilitando uma articulação entre esses dois aspectos da linguagem Matemática.

\section{INVESTIGAÇÃO MATEMÁTICA COM 0 GEOGEBRA (METODOLOGIA)}

A ideia da Investigação Matemática com o GeoGebra consiste em articular o saber matemático historicamente construído com uma metodologia de ensino na qual o aluno participa ativamente do processo. Logo, orientamos a divisão da atividade ou aula em etapas e ainda começar determinado tema, utilizando um problema motivador, a partir do qual se chega ao aspecto nuclear do objeto a ser estudado.

Assim, por exemplo, se vamos estudar o teorema de Pitágoras, a ideia é criar um problema cuja investigação remeterá à sua essência. Essa parte do problema é fundamental, uma vez que, ao longo da história da humanidade, os matemáticos resolveram problemas que nasceram de necessidades próprias e necessárias a sua sobrevivência. Em sua essência, a Matemática se desenvolveu numa dinâmica de resolver problemas.

Uma vez definido um problema de investigação e explicado aos alunos claramente o que se deseja, o professor, de preferência num laboratório de ensino, coloca o aluno em atividade e começa a explorar a primeira etapa que é a possibilidade de experimentar a situação problema, isto é, alunos e professor podem, em um laboratório de informática, usar o software para trabalhar atividades matemáticas que permitem o aluno, movimentando os objetos matemáticos, comparar suas representações algébricas e geométricas, perceber propriedades, definições e construir conceitos através da interação com o objeto de conhecimento que é possibilitada com a mediação do professor.

A segunda fase do processo seria levantar conjecturas relacionadas à primeira etapa. Conjecturar significa que, depois de perceber as relações suscitadas na experimentação, é possível vislumbrar propriedades, relações, resultados gerais importantes para o bom desenvolvimento do ensino-aprendizagem da Matemática. As conjecturas desempenham um papel importante no desenvolvimento da matemática. São situações que precisam ser resolvidas e estão articuladas com o desenvolvimento do conhecimento matemático. Uma vez, explorado essa conjectura, o aluno pode enunciá-la como um resultado a ser explorado, até o entendimento total dele.

A terceira etapa é a formalização que seria a demonstração matemática do fato propriamente dita ou uma contra proposição da conjectura levantada, nos dois casos com um argumento pedagógica compatível à série que se está trabalhando, uma validação da conjectura utilizando uma argumentação que promova aprendizado. Tal atitude é importante pois não podemos, através da experimentação, generalizar os resultados sob o risco de não estarmos praticando os ideais da Matemática. Os resultados dessa ciência devem ser argumentados, respeitando os níveis de entendimento do aluno. Não é uma boa ideia provar que uma função do segundo grau, com a > 0, tem a concavidade para cima pelo uso da operação derivada primeira ou segunda numa turma do nono ano do ensino fundamental ou numa turma de primeiro ano do ensino médio, mas podemos usar argumentos compatíveis para se provar tal resultado.

Depois de experimentar, conjecturar e formalizar o saber matemático, é importante tentar fazer a generalização do resultado, isto é, investigar outras situações pertinentes, situações particulares, enfim, explorar o alcance do resultado obtido. Foi surpreendente, em muitos casos, que releituras de conteúdos tenham nos dado situações que ainda não tinham sido percebidas e também, em muitas atividades que se pretendia investigar determinadas propriedades, o aluno percebeu outras.

Ressaltamos que, durante todo processo, é necessário que o professor faça um monitoramento de todas as suas etapas e que todos os alunos entrem em atividade participando ativamente da aula; assim, o monitoramento garantirá que todos desenvolverão as etapas e, por conseguinte, terão mais chance de êxito na aprendizagem. Nenhum aluno deve, portanto, ficar para traz e todos devem ser incentivados a 
desenvolver um trabalho coletivo, compartilhando seus aprendizados, ajudando a consolidar os saberes. Pessoas mais preparadas tem papel fundamental no desenvolvimento cognitivo de outros que tem menos experiência.

\section{AVALIAÇÃO DA APRENDIZAGEM NA ATIVIDADE DE INVESTIGAÇÃO MATEMÁTICA COM 0 GEOGEBRA (DESENVOLVIMENTO)}

Como a investigação é uma atividade pedagógica, uma avaliação da atividade é muito importante. Aqui pensamos a avaliação como está em Luckesi (1999, p. 85-101), ou seja, a avaliação do trabalho pedagógico foge dos exames tradicionais, onde se procura atribuir um número ao aprendizado do aluno. Discordamos desse tipo de avaliação por pensarmos que as avaliações tradicionais exploram demasiadamente a memória do aluno, não explorando ações mentais que podem ser construídas no processo de ensinoaprendizagem. Assim, adotamos um modo de avaliar dentro da própria Investigação que se estabelece no início do processo e perpassa todo ele pelo uso do monitoramento contínuo da atividade. Neste monitoramento, realizamos ações contínuas com relação a superação das dificuldades imediatas. Não trabalhamos de forma que alunos fiquem com dificuldades e não acompanhem o processo. Trabalhamos no sentido de coletividade, onde todos cooperam entre si e chegam ao mesmo estágio.

Esse tipo de trabalho vem sendo apresentado a algum tempo em cursos de formação de professores de Matemática. Em nosso caso, geralmente, na disciplina de Tecnologias na educação Matemática e na Prática Profissional como Componente Curricular (PPCC), sendo que neste último tem um caráter mais introdutório e onde se enfatiza, inicialmente, uma interação com as ferramentas do software no sentido de apropriar do significado delas, mas já articulando com alguma atividade no contexto da Matemática. Na PPCC os temas trabalhados são todos relacionados a conteúdo do ensino fundamental. Na parte final da disciplina, os alunos são motivados a trabalhar com a investigação matemática com o Geogebra. Para tanto, são apresentados alguns exemplos que são desenvolvidos juntamente com eles no laboratório de informática.

Já na disciplina de Tecnologias no Ensino da Matemática, além de uma discussão mais profunda sobe a Investigação Matemática com o Geogebra, também abordamos teóricos da área de tecnologias e da didática, essa discussão tem o objetivo de que os alunos tenham consciência das teorias envolvidas e que a partir delas seja constituída suas ações pedagógicas.

Assim, a proposta é colocada com suas justificativas teóricas que busca, num primeiro momento, amadurecer o aluno e, também, capacitá-lo a aplicar teorias de aprendizagem nos processos de ensinoaprendizagem de conteúdos matemáticos.

Durante o desenrolar da disciplina são apresentadas inúmeras situações de investigação em temas elementares. Concebemos a investigação com o Geogebra como uma atividade que pode ser desenvolvida em todos os conteúdos de Matemática, embora sabemos que essa seja, apenas, uma contribuição a outras metodologias existentes.

No planejamento da disciplina de Tecnologias e da PPCC, apresentadas no início do semestre aos alunos do curso de licenciatura em matemática, deixa-se muito claro que o processo avaliativo da disciplina consistirá do desenvolvimento de duas atividades avaliativas fundadas na apresentação de projetos investigativos com o Geogebra. Como a disciplina Tecnologias na Educação Matemática tem amplas possibilidades de desenvolvimento, agregamos um processo avaliativo contínuo para discutir com os estudantes as outras tecnologias e suas articulações com a educação Matemática. A avaliação, portanto, consiste de duas atividades principais e de diversas atividades integradas durante o percurso da disciplina.

Mas o que se avalia neste processo? Usamos como critério avaliativo e isso é deixado muito claro ao estudante que o objetivo principal da atividade é que o escolar se aproprie da essência do conceito, neste caso, avaliamos se o estudante de licenciatura em Matemática compreende e sabe aplicar tal metodologia e também se apropriou-se do conhecimento matemático que está trabalhando. Assim, na apresentação da atividade (ou do projeto), esta deve assumir um caráter de Investigação Matemática com o Geogebra. Desse modo, o aluno da disciplina apresenta como se fosse uma aula, onde o apresentador deve encarar a atividade como uma aula real, ou seja, todos devem se envolver no processo e todos deverão apresentar sua proposta. A apresentação é individual ou em duplas, dependendo do número de alunos de cada turma. Por se tratar de uma disciplina exclusiva do curso de licenciatura em Matemática, até hoje não excedeu a quantidade de vinte alunos. 
Temos obtido resultados relevantes com este trabalho e o envolvimento de vários alunos com a proposta, levando-a para além da disciplina. Entretanto, uma das dificuldades encontradas, refere-se ao fato de que os alunos de licenciatura carecem de uma formação em didática mais profunda, isso é muito comum nos cursos de licenciatura em Matemática o que dificulta o aluno a compreender as diferenças metodológicas e as filiações teóricas que tanto atrapalham o trabalho pedagógico.

Outros alunos têm até mesmo produzido artigos científicos com a Investigação Matemática com o Geogebra. Além disso, a proposta despertou o interesse de muitos colegas de trabalho, desenvolvendo trabalhos de monografia de especialização. A seguir arrolamos alguns destes trabalhos.

\section{RESULTADOS E DISCUSSÃO}

No artigo Investigação matemática com o Geogebra, em uma propriedade dos polígonos, Vaz, Vasconcelos e Freitas Filho (2015) utilizam a Investigação Matemática com o Geogebra para estudar uma propriedade dos polígonos. Identificaram, na condução da atividade, o potencial da proposta, uma vez que nos auxiliou na generalização do resultado a partir de uma álgebra vetorial elementar sobre casos particulares. Segundo os autores, a utilização do software GeoGebra foi importante na percepção da propriedade, através das demonstrações visuais realizadas em diversas situações e conjecturas suscitadas a partir das experimentações.

A investigação matemática com o software Geogebra por meio do estágio supervisionado foi uma pesquisa realizada por Oliveira e Vaz (2014) e apresentou os resultados parciais do projeto de Mestrado Profissional em Educação para Ciências e Matemática desenvolvido no Instituto Federal de Goiás, Campus Jataí, buscando identificar algumas contribuições da realização do Estágio Supervisionado com pesquisa na formação dos acadêmicos do curso de Licenciatura em Matemática da Universidade Estadual de Goiás (UEG), Campus Iporá. De acordo com as pesquisas dos acadêmicos, a Investigação Matemática com o Geogebra foi importante no processo de ensino dos conteúdos de Matemática por permitir a aprendizagem dos alunos pelas suas próprias construções, realizadas de forma dinâmica na interação com o software. 0 professor mediador foi um orientador no trabalho investigativo enquanto os alunos aprenderam raciocinando, levantando hipóteses, conjecturando, experimentando, testando e formalizando matematicamente os conteúdos. Os resultados parciais mostram que a pesquisa possibilitou aos acadêmicos a oportunidade de refletir sobre o ensino de Matemática, sobre a metodologia de Investigação Matemática, sobre o uso dos softwares educacionais, em especial do Geogebra, como recurso de ensino e aprendizagem por meio da vivência das suas primeiras experiências na sala de aula em um contexto desafiador.

Utilizando a investigação matemática com o Geogebra para caracterizar funções de uma variável real que são inversas de si mesmas foi um trabalho realizado por Vaz e Vasquez (2015), resultado de um estudo que investigou as propriedades das funções de uma variável real que são inversas de si mesmas. Começa apresentando casos particulares e na percepção de uma infinidade de soluções que permitiram investigar propriedades interessantes conjecturadas a partir de casos experimentados com o auxílio do software Geogebra. Na formalização dessas propriedades, utilizou-se ideias obtidas da visualização e dinamização que o software permite. A experiência mostra que a investigação Matemática com o Geogebra proposta em Vaz (2012) é um critério eficaz para este tipo de trabalho.

Experimentando, Conjecturando, Formalizando e Generalizando: articulando investigação matemática com a Geogebra é um artigo produzido por Vaz (2012), onde apresenta uma proposta de trabalho com o software Geogebra inspirada no construtivismo pela ação baseada em experimentar, conjecturar, formalizar e generalizar o saber matemático. As atividades foram planejadas em projetos de pesquisas desenvolvidos com grupos de diferentes níveis levando em consideração a participação coletiva dos alunos envolvidos no processo. Nas atividades, em muitos momentos, foi possível desenvolver a investigação matemática, pois as conjecturas suscitadas em muitas experiências permitiram o desenvolvimento de descobertas e releituras interessantes, possibilitando ao aluno perceber o caráter dedutivo e generalizante da Matemática.

\section{CONSIDERAÇÕES FINAIS}

No Brasil, nos últimos anos, temos assistido ao avanço das políticas neoliberais na educação como nunca antes. Tal perspectiva tem modificado a estrutura de nosso ensino transformando-o numa atividade que não tem como foco o conhecimento teórico, mas sim, o ensino empírico. 0 ensino teórico é aquele capaz de 
formar ações mentais nos escolares, auxiliando-os a formar ações mentais e resolver problemas adequadamente, para tanto, no processo, o aspecto nuclear do objeto científico deve ser revelado; já o ensino empírico é aquele que trabalha as características externas dos objetos científicos, obtidas sensorialmente e, portanto, não forma ações mentais nos escolares, embora seja um tipo de conhecimento necessário ao científico (SILVA, 2014).

Essas políticas públicas orientadas por organismos multilaterais impõem, na nossa educação, um ensino baseado em testes, ou seja, orienta-se a educação para que se tenha como fim único o treinamento do escolar para esses testes. Também conseguem alterar a metodologia do professor utilizando a meritocracia, incentivando, ao mesmo tempo impondo, o cumprimento de determinadas tarefas pelo professor, em detrimento do saber científico (SILVA, 2014).

Uma alternativa a esse tipo de política é que o professor adote metodologias e filiações teóricas que transformem o conhecimento empírico do aluno em conhecimento teórico. Para tanto, a escola formadora de professores tem que pensar formas inovadoras de fazê-lo. A partir disso, o professor poderá pensar modos de avaliar de acordo com essa proposta, em sua prática educacional diária. Como passo inicial deve entender que o ensino e a avaliação tradicional atendem interesses que não são legítimo a uma educação libertadora, sendo reprodutora de uma cultura de interesse mercantilista.

A percepção do processo de educação e avaliação inovadoras devem ser apresentadas nos cursos de formação de professores de forma enfática, para que o futuro professor perceba a importância de uma educação científica adequada ao enfretamento dos problemas escolares com determinação.

Apresentamos a metodologia da Investigação Matemática com o Geogebra como uma articulação entre o conhecimento Matemático e as Tecnologias numa didática especifica. Como todo processo pedagógico, entendemos que a avaliação dessa proposta deva ser realizada em três momentos complementares, a saber: no monitoramento das etapas, no fim do processo de formação e na produção posterior ao processo.

O monitoramento da atividade investigativa permite o acompanhamento do aluno pelo professor em todo processo de atividade e entendemos isso como um recurso potencializador da aprendizagem, permitindo ao professor perceber as dificuldades inerentes ao processo e, a partir disso, atuar junto ao aluno para que supere essas dificuldades e continue o processo investigativo com seus pares.

Além do mais, o aluno, futuro professor, deve apresentar duas atividades de investigação para seus pares e será avaliado com relação a sua capacidade de realizá-las, cumprindo todas as etapas propstas.

Com relação avaliação da produtividade, consideramos exitosas as experiências vivenciadas com nossos alunos, futuros professores de matemática. Esse dado é comprovado a partir das experiências realizadas no interior do curso de Matemática que trabalhamos notadamente na produção científica sobre o tema por alunos do curso em monografias e artigos científicos publicados.

\section{REFERÊNCIAS}

[1] LIBÂNEO, J. C. 0 ensino da Didática, das metodologias específicas e dos conteúdos específicos do ensino fundamental nos currículos dos cursos de Pedagogia. Revista Brasileira de Estudos Pedagógicos, Brasília, v. 91, n. 229, set-dez. 2010. p. 562-583. Disponível em: http://rbep.inep.gov.br/index.php/rbep/article/download/630/610. Acesso em: 15 Ago. 2019.

[2] LUCKESI, Cipriano Carlos. Verificação ou Avaliação: o que pratica na escola? In: LUCKESI, Cipriano Carlos. Avaliação da aprendizagem escolar: estudos e proposições. 9. ed. - São Paulo: Cortez, 1999. p. 85-101. Disponível em: https://docplayer.com.br/77769386-Avaliacao-da-aprendizagem-escolar.html. Acesso em: 15 Ago. 2019.

[3] OLIVEIRA, Claudimary Moreira Silva. A investigação matemática com o GeoGebra no estágio com pesquisa do curso de licenciatura em matemática da UEG/Iporá. 2015. Dissertação (Mestrado em Mestrado em ensino de ciências e educação Matemáti) - Instituto Federal de Educação, Ciência e Tecnologia de Goiás, Fundação de Amparo a Pesquisa do Estado de Goiás. Orientador: Duelci Aparecido de Freitas Vaz. Disponível em: http://www.cefetgo.br/attachments/article/1279/Disserta\%C3\%A7\%C3\%A3oClaudimary\%20Moreira\%20Silva\%200liveira-2015\%20(.pdf\%204031\%20kb).pdf Acesso em: 16 Ago. 2019.

[4] SILVA, Simônia Peres da. O processo de implementação das políticas educacionais e repercussões nas formas de gestão da escola e no processo de ensino-aprendizagem [manuscrito]: o Pacto pela Educação em Goiás / Simônia Peres da Silva. - Goiânia, 2014. Disponível em: http://tede2.pucgoias.edu.br:8080/bitstream/tede/709/1/SIMONIA\%20PERES\%20DA\%20SILVA.pdf. Acesso em: 19 Ago. 2019. 
[5] VAZ, Duelci Aparecido de Freitas. Experimentando, conjecturando, formalizando e generalizando: articulando investigação matemática com o geogebra. Educativa (Goiânia. Online), v. 15, p. 39-51, 2012. Disponível em: http://seer.pucgoias.edu.br/index.php/educativa/article/download/2491/1549. Acesso em: 15 Ago. 2019.

[6] VAZ, Duelci Aparecido de Freitas; JESUS, Elivanete Alves de. Investigação matemática com o GeoGebra: um exemplo com matrizes e determinantes. Boletim GEPEM (Online), v. 62, p. 165-170, 2013. Disponível em: http://doi.editoracubo.com.br/10.4322/gepem.2014.030. Acesso em: 28 ago. 2017.

[7] VAZ, Duelci Aparecido de Freitas; VASCONCELOS, José Eder Salvador de; FREITAS FILHO, Osni Oliveira de. Investigação matemática com o GeoGebra em uma propriedade dos polígonos. Revista do Professor de Matemática. São Paulo: SBM, 2015. n. 1, v. 3. ISSN 2319-023X. Disponível em: http://pmo.sbm.org.br/wpcontent/uploads/sites/16/2016/02/pmo-sbm-v003-n001-vaz-vasconcelos-e-freitas-filho.pdf Acesso em: 16 Ago. 2019.

[8] VAZ, Duelci Aparecido de Freitas; VASQUEZ, Julio Cezar Saavedra. Utilizando a investigação matemática com o GeoGebra para caracterizar funções de uma variável real que são inversas de si mesmas. Revista educativa. Goiânia: Gráfica PUC GOIÁS, 2015. v. 17, n. 2, p. 656-668. Disponível em: http://tede2.pucgoias.edu.br/index.php/educativa/article/viewFile/4566/2604. Acesso em: 28 ago. 2017. 


\section{Capítulo 17}

\section{O pensamento relacional na Álgebra: O que sabem os estudantes?}

\section{Sheila Marques Moreira Medeiros \\ Mayara Dias de Araújo \\ Severina Andréa Dantas de Farias}

Resumo: Este estudo buscou identificar os conhecimentos prévios de alunos do $5^{\circ}$ ano do Ensino Fundamental em relação à compreensão da álgebra na Matemática de uma escola pública. Assim nos aproximamos de documentos oficiais vigentes e de estudos teóricos que discutem o pensamento relacional na Álgebra. 0 estudo é de caráter qualitativo e foi dividido em duas etapas: identificação do perfil e dos conhecimentos prévios dos participantes com relação ao conhecimento algébrico. Para isso nos aproximamos de três turmas de $5^{\circ}$ ano do Ensino Fundamental, com setenta e sete estudantes de uma escola pública, campesina, no município de João Pessoa, Paraíba. Os instrumentos utilizados foram o questionário semiestruturado e o diário de campo no período de maio a agosto de 2019. Como resultado constatamos que a maioria dos participantes não compreendeu a função de elementos faltantes apresentadas em sentenças, bem como a função do sinal de igualdade. Concluímos que os participantes apresentaram dificuldades do pensamento relacional quando este foi apresentado em sentenças envolvendo adição e subtração para solucionar as questões, sendo evidenciado o pouco conhecimento prévio dos participantes com relação a este tipo de pensamento tão necessário a formulação de abstrações em situações-problema de Matemática.

Palavras-chave: Ensino de Matemática; Ensino Fundamental; Pensamento relacional; Ensino de Álgebra. 


\section{INTRODUÇÃO}

Os documentos oficias tratam de garantir a oferta da educação básica e gratuita, como é citado na Emenda Constitucional no 59/2009 assegurando uma Educação Básica obrigatória, gratuita para todos, garantido o acesso escolar na idade própria (BRASIL, 2009).

Para que o processo educacional possa acontecer de forma plena, é fundamental que o aluno encontre condições adequadas no ambiente escolar, proporcionando a ele um resultado satisfatório no processo de ensino e aprendizagem, respeitando as diferenças apresentadas por cada um na sua individualidade.

Os estudantes nessa etapa passam por mudanças que interferem diretamente no processo de aprendizagem, desde aspectos físicos, sociais e emocionais que precisam ser desenvolvidos adequadamente devendo garantir a aprendizagem curricular e desenvolvimento pleno no aluno (BRASIL, 2017).

Como forma de padronizar e oferecer uma educação básica com qualidade nas diferentes regiões do Brasil, está sendo normatizado por documentos curriculares (BRASIL, 2017) a Base Nacional Comum Curricular - BNCC, que pressupõe: [...] que a aprendizagem em Matemática está intrinsecamente relacionada à compreensão, ou seja, à apreensão de significados dos objetos matemáticos, sem deixar de lado suas aplicações (BRASIL, 2017, p. 274).

A Matemática aparece como disciplina obrigatória que deve ser discutida desde os primeiros anos inicias da Educação Básica, conforme legislação vigente (BRASIL, 2017). Esta ciência está presente na vida do aluno, seja no cotidiano, seja na escola; sempre provocando seus conhecimentos para proporcionar seu desenvolvimento em várias habilidades da vida de modo geral.

Com base nessa nova legislação foram apresentados diferentes campos da Matemática que reúnem um conjunto de ideias fundamentais e que produzem articulações caracterizados por unidades temáticas, nas quais são: Números, Álgebra, Geometria, Grandezas e Medidas, e Probabilidade e Estatística, sendo estas correlacionadas à formulação de habilidades a serem desenvolvidas ao longo do Ensino Básico.

Neste estudo, nos detivemos a unidade temática Álgebra, tendo como finalidade o desenvolvimento de um tipo especial de pensamento - pensamento algébrico - que é essencial para utilizar modelos matemáticos na compreensão, representação e análise de relações quantitativas de grandezas e, também, de situações e estruturas matemáticas, fazendo uso de letras e outros símbolos (BRASIL, 2017).

A Álgebra constitui um dos grandes ramos da Matemática. Esta tem como um de seus objetivos de estudo no ensino básico de é desenvolver o pensamento algébrico nos educandos. Este pensamento inclui a capacidade de manipulação de símbolos, mas, vai muito além disso, como a capacidade de lidar com expressões algébricas, equações, inequações e funções. Inclui também, igualmente, a capacidade de lidar com outras relações e estruturas matemáticas e usá-las na interpretação e resolução de problemas matemáticos ou de outros domínios. Podemos dizer que o pensamento algébrico inclui três vertentes: representar, raciocinar e resolver problemas.

Diante do que aqui foi exposto sobre o ensino da álgebra, elegemos como a problemática principal de estudo: Quais os conhecimentos prévios dos estudantes de 5o ano de uma escola pública com relação ao pensamento relacional na álgebra?

Desta forma a presente pesquisa teve como objetivo geral identificar os conhecimentos prévios de alunos do 5o ano do Ensino Fundamental em relação à compreensão da álgebra na Matemática de uma escola pública com base nos conhecimentos trazidos pelos estudantes com relação ao pensamento algébrico.

\section{A ÁLGEBRA ESCOLAR}

Na discussão da Álgebra escolar temos o pensamento relacional, que segundo Van de Walle (2009), possibilita a ampliação da percepção dos estudantes com relação a matemática ao estimular a observação e o uso de relações numéricas existentes, para favorecer a compressão de relações simbólicas com os diversos conhecimentos matemáticos.

A Matemática provoca naturalmente ao aluno a necessidade de pensar, e assim conseguir realizar inferências diante de conceitos, procedimentos e fatos das situações apresentada a ele. Quando colocamos a Álgebra na discussão, essa necessidade se torna mais evidente. Segundo Kaput (1999 apud VAN DE WALLE, 2009, p. 288), a álgebra "[...] envolve generalizar e expressar essa generalização usando linguagens cada vez mais formais". A matemática provoca, naturalmente, o ato de pensar, de interpretar, 
seja qual for o conceito apresentado, porém, na álgebra com maior relevância. Com isso o aluno pode se sentir mais próximo da matemática, entendendo que os dados analisados nas questões são aplicáveis na sua vida cotidiana, e assim entender que ela não é "para poucos", mas sim para todos.

Segundo a BNCC (BRASIL, 2017), os objetos de aprendizagem que conduzem a unidade temática Álgebra devem ser apresentados e discutidos em atividades que envolvam os seguintes conhecimentos matemáticos elencados abaixo, espera-se que sejam desenvolvidos ao longo do Ensino Fundamental anos iniciais.

- Sequências recursivas: observando regras e padrões.

- Construção de sequências repetitivas e identificação de regularidades;

- Relação de igualdade

- Sequência numérica recursiva formada por múltiplos de Número Natural;

- Sequência numérica recursiva formada por números que deixem o mesmo resto ao ser dividido por um mesmo número diferente de zero;

- Relações entre adição e subtração e entre multiplicação e divisão;

- Propriedades da igualdade;

- Propriedade da igualdade e noções de equivalência;

- Grandezas diretamente proporcionais;

- Problemas envolvendo a partição de um todo em duas partes proporcionais.

Com base nos conhecimentos matemáticos apresentados na BNCC (2017), elaboramos atividades de Álgebra para os anos iniciais que possibilitam discutir alguns objetos de aprendizagem afim que sejam assimilados pelos estudantes. Pata isso, as atividades não deverão se apoiar em mera repetição de teoremas, nem em memorização de resultados, mas que proporcionem uma reflexão ao estudante, mediante a aquisição do conhecimento matemático e que possibilitem estabelecer relações entre teoria e prática do que é estudado na escola com seu contexto social.

Nessa perspectiva, os objetos de conhecimento matemático apontam para a priorização do desenvolvimento e da compreensão dos estudantes. Espera-se que as atividades proporcionem experiências escolares que possibilite a assimilação e internalização dos principais conteúdos de álgebra, quando estes forem aplicados ao ensino da Matemática escolarizada.

Com relação as dificuldades citadas nas formas de generalizações dentro da álgebra, encontramos o sinal da igualdade com grande destaque para a dificuldade na compreensão dos alunos sobre os seus significados, pois não lhe atribuído o sentido de equivalência.

Para Van de Walle (2009), o sinal de igualdade é um dos símbolos mais importantes na aritmética, na álgebra e em toda matemática ao usar números e operações. Ao mesmo tempo, que o símbolo da igualdade “ = " é muito mal compreendido entre os estudantes, sendo usado na maioria das vezes apenas para fornecer resultados.

As questões apresentavam identidades com elementos ausentes, que segundo Van de Walle (2009, p. 289 e 290) o pensamento relacional vai além do cálculo e em vez disso se concentra em como uma operação ou série de operações se relaciona com as outras. Baseado nesse fundamento, elaboramos questões com sentenças abertas de acordo com a BNCC (BRASIL, 2017), nas quais os itens foram distribuídos em questão 1 e 2 que tratam da resolução das sentenças abertas e da discussão de uma situação problema na verificação de leitura, interpretação de pequenos textos, na escrita e na compreensão de elementos ausentes para representação, conforme indicado no Quadro 1. Para melhor compreensão, estruturamos alguns itens relacionando-os com as habilidades da BNCC conforme apresentamos no Quadro 1: 
Quadro 1 - Itens do questionário com habilidades da BNCC (BRASIL, 2017)

\begin{tabular}{|c|c|}
\hline Questão 1. & Habilidades \\
\hline a) $18+25=\square$ & $\begin{array}{c}\text { (EF03MA11) Compreender a ideia de igualdade para escrever } \\
\text { diferentes sentenças de adições. }\end{array}$ \\
\hline b) $\square+17=101$ & \multirow{3}{*}{$\begin{array}{c}\text { (EF04MA13) Reconhecer, por meio de investigações, utilizando } \\
\text { a calculadora quando necessário, as relações inversas entre as } \\
\text { operações de adição e de subtração. }\end{array}$} \\
\hline c) $9+\square=10$ & \\
\hline e) $\square-12=50$ & \\
\hline d) $29+\square=30+5$ & \multirow{2}{*}{$\begin{array}{l}\text { (EF04MA15) Determinar o número desconhecido que torna } \\
\text { verdadeira uma igualdade que envolve as operações } \\
\text { fundamentais com números naturais. }\end{array}$} \\
\hline f) $1023-23=\square+523$ & \\
\hline $\begin{array}{c}\text { Questão } 2 . \\
\text { Situação problema - } \\
\begin{array}{c}17+2=2+\square\end{array}\end{array}$ & $\begin{array}{c}\text { (EF04MA15) Determinar o número desconhecido que torna } \\
\text { verdadeira uma igualdade que envolve as operações } \\
\text { fundamentais com números naturais. }\end{array}$ \\
\hline
\end{tabular}

As questões apresentadas no Quadro 1 foram elaboradas de acordo com os conteúdos apresentados em anos anteriores, correspondendo a itens do $3^{\circ}$ e $4^{\circ}$ ano do Ensino Fundamental e com base na BNCC (BRASIL, 2017).

\section{ATIVIDADES PARA SUPERAR DIFICULDADES NA ÁLGEBRA}

As atividades de álgebra propostas neste estudo com intuito de superar as principais dificuldades devem priorizar:

A discussão das propriedades da igualdade, noção de equivalência, descoberta de números desconhecidos e sentenças verdadeiras ou falsas utilizando a representação da balança de dois pratos. Depois apresente uma balança de dois pratos, ainda muito utilizada em feiras de nossa região, para que os alunos entendam o instrumento e sua importância. Neste momento o professor deve realizar perguntas investigativas para saber do conhecimento da turma sobre o instrumento, tais como: Vocês sabem o que é uma balança de dois pratos? (Figura1). Onde ela é utilizada? Com a ajuda de frutas da região e objetos da sala de aula será realizada a explosão conceitual da igualdade e da equivalência de sentenças por meio da manipulação de objetos, observando conceitos de maior $(>)$, menor $(<)$ ou igual $(=)$, conforme a Figura. Após observação da balança, solicite que os alunos registrem suas descobertas no caderno. Em seguida realizar uma proposta de atividades para que os alunos registrem e identifiquem através das representações das balanças.

Figura 1 - Representação de atividades utilizando balanças

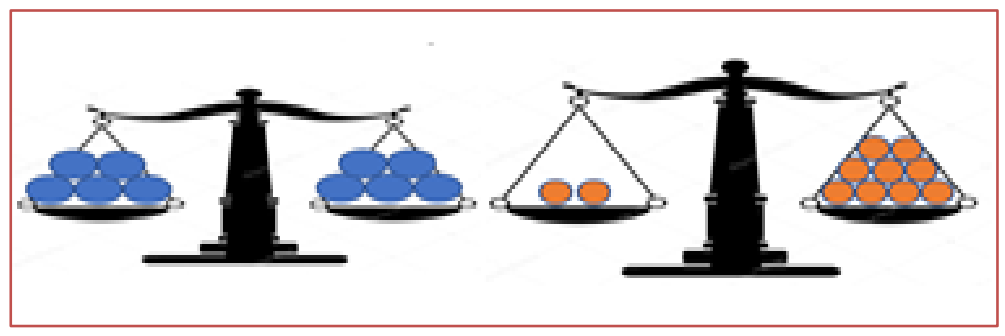

Fonte: Elaboração das autoras 
Apresentar aos alunos o desafio de construir sentenças. Distribuir dados com as faces indicando os símbolos das operações matemáticas (adição, subtração, multiplicação e divisão.) E as duas faces restantes, uma representada pelo sinal de igualdade (=) e a outra por um ícone ou desenho que represente o elemento ausente e um dado para registro aritmético. Em seguida, organizar os alunos em duplas, onde cada dupla jogará os dados até formular uma sentença aberta, registrando e resolvendo o item, como exemplo no Quadro 2:

Quadro 2 - Sentenças abertas

a) $+6=12$
b) $9+1=\overline{=18}$
c) $9+\square=5-3$
d) $6-\square=22 \times 4$
e) $4+\overline{6}=\overline{ }$
f) $\quad=22 \times$

Fonte: Elaboração das autoras

Por exemplo, os dados serão jogados pelas duplas, o número indicado, operação ou figura deverá ser registrado pelos alunos, até elaborar uma sentença aberta. Ao final os alunos deverão expor para turma quais sentenças formularam com o preenchimento dos espaços e apresentando suas soluções.

A discussão com sentenças abertas, manipulação de objetos na discussão conceitual de maior ( $>$ ), menor $(<)$ ou igual (=) e identificação de termos desconhecidos em sequência geométricas e numéricas. Como sugerido na Figura 3, onde é solicitado ao aluno que apresente o próximo elemento da sequência geométrica:

Figura 3 - Identificar o próximo elemento da sequência geométrica

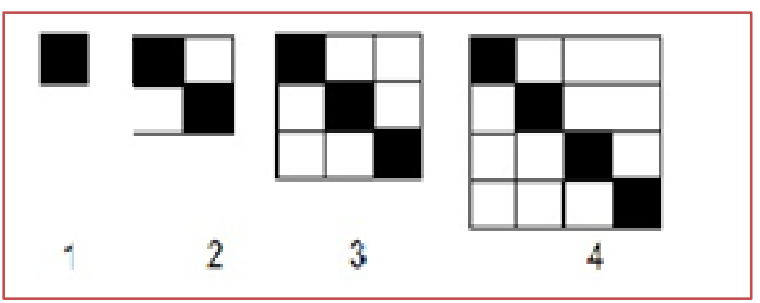

Fonte: Caderno Soma (2017, p. )

A discussão a partir de uma resolução de problema:

Eva levou pirulitos para dividir com sua turma na escola. Na quinta-feira levou 10 pirulitos de morango e 5 pirulitos de abacaxi e distribuiu com todos os alunos da turma. Na sexta-feira, levou 5 pirulitos de morango e o restante de abacaxi. Pergunta-se: Quantos pirulitos de abacaxi Eva levou para a escola na sexta-feira? Represente a situação através de desenho.

\section{METODOLOGIA DO ESTUDO}

0 estudo adotou a perspectiva metodológica de abordagem exploratória, de caráter qualitativo, que foi definido por Gil $(2011,27)$ como tendo "[...] finalidade de esclarecer e modificar conceitos e ideias, tendo em vista a formulação de problemas mais precisos ou hipóteses pesquisáveis para estudos posteriores".

Quanto aos instrumentos de pesquisa utilizados foram o questionário semiestruturado e o diário de campo no período de maio a agosto de 2019. A análise de dados priorizou aspectos quantitativos e qualitativos nas atividades que priorizaram aspectos do pensamento relacional na álgebra. 
A pesquisa foi desenvolvida por duas estudantes do curso de Pedagogia, sob orientação docente sendo parte de uma pesquisa vinculada ao Programa de Licenciatura - PROLICEN, da Universidade Federal da Paraíba, com intuito de identificar conhecimentos prévios dos alunos sobre o pensamento relacional. Contamos com a participação de 77 alunos em três turmas de uma escola pública do 5o ano do Ensino Fundamental, do município de João Pessoa, Paraíba, no período de maio a agosto de 2019.

\section{RESULTADOS E DISCUSSÃO}

Inicialmente, nosso primeiro passo foi realizar um estudo diagnóstico. Para isso utilizamos um questionário semiestruturado composto por duas partes: verificação do perfil dos participantes e seus conhecimentos prévios com relação à álgebra escolarizada. Os resultados estão sintetizados nas Tabelas 2 e 3:

Tabela 2: Perfil dos participantes

\begin{tabular}{|c|c|c|}
\hline QUESTÕES & \multicolumn{2}{|c|}{ RESPOSTAS } \\
\hline Distância da escola & $41 \%$ moram perto da escola & $\begin{array}{l}56 \% \text { moram longe } \\
3 \% \text { não responderam }\end{array}$ \\
\hline Afinidade pela Matemática & $35 \% \operatorname{sim}$ & $\begin{array}{l}59 \% \text { não } \\
6 \% \text { não responderam }\end{array}$ \\
\hline
\end{tabular}

Fonte: Elaboração das autoras

Na Tabela 2, inicialmente perguntamos qual a idade dos participantes. Verificamos que a maioria dos participantes indicaram que 97\%, possuem idades superior a 10 anos de idade. Estes dados indicam que muitas crianças estão fora da faixa etária indicada, segundo os documentos oficiais vigentes (PARAIBA, 2010; BRASIL, 2017).

Quanto ao aspecto de gênero, verificamos na Tabela 1 que a maioria, 59\%, pertence ao sexo masculino, enquanto que $41 \%$ ao gênero feminino. Estes dados indicam uma proximidade do equilíbrio nas salas participantes com relação ao gênero.

Com relação ao município onde residem os alunos, constatamos que $66 \%$ indicaram que residem da zona urbana do município participante, enquanto que $25 \%$ são estudantes residentes da zona rural deste mesmo município.

O meio de locomoção que os alunos utilizam para realizar seu deslocamento de sua residência até a escola verificamos que a maioria, $46 \%$, se dirigem à escola caminhando, a pé, enquanto que $15 \%$ utilizam motos, 9\% usam bicicletas, 18\% utilizam o transporte urbano, 9\% usam outros meios de transporte e 3\% não responderam ao item. Percebemos com esses dados que boa parte dos alunos se deslocam a pé devido à proximidade da escola. Os demais utilizam meios distintos de transporte devido não residirem próximo a instituição.

Quanto a afinidade pela disciplina de Matemática, constatamos que 35\% dos alunos participantes afirmaram que gostam da disciplina, enquanto que 59\% não possuem afinidade pela matemática e 6\% não responderam. Este fato muito nos preocupa, pois, a motivação e o direcionamento à aquisição de novos conhecimentos são necessários para aprendizagem da matemática. Este fato indica rejeição inicial dos 
participantes o que pode ser um empecilho à aprendizagem desta ciência, causando um obstáculo epistemológico, que as vezes são decorrentes de anteriores (FARIAS, AZEREDO, RÊGO, 2016).

Tabela 3: Questões matemáticas envolvendo o pensamento relacional

\begin{tabular}{|c|c|c|c|}
\hline \multirow[t]{2}{*}{ Questões } & \multicolumn{2}{|c|}{ Resultados } & Não respondeu \\
\hline & Acertos & Erros & \\
\hline a) $18+25=\square$ & $69 \%$ & $28 \%$ & $3 \%$ \\
\hline b) $\square+17=101$ & $47 \%$ & $28 \%$ & $25 \%$ \\
\hline c) $9+\square=10$ & $91 \%$ & $6 \%$ & $3 \%$ \\
\hline d) $29+\square=30+5$ & $6 \%$ & $88 \%$ & $6 \%$ \\
\hline e) $\square-12=50$ & $38 \%$ & $56 \%$ & $6 \%$ \\
\hline f) $1023-23=\square+523$ & $0 \%$ & $81 \%$ & $19 \%$ \\
\hline
\end{tabular}

Fonte: construção das autoras

A Tabela 3 apresenta os dados dos questionários das três turmas de 5o anos participantes, com relação aos conhecimentos prévios do pensamento relacional da álgebra no momento da investigação.

A primeira questão, o item a), tratou de investigar os números faltantes com relação ao preenchimento das sentenças e análise do sinal da igualdade, atentando para o uso correto e adequado da simbologia matemática e da compreensão do pensamento relacional sem a necessidade imediata de cálculos para o preenchimento correto das sentenças.

Na letra a) constatamos que 69\% dos participantes responderam corretamente, pois compreendem que o sinal da igualdade está sendo atribuído ao resultado da operação. Fato este que já foi modificado nos itens, letra b) com resultado de $47 \%$ e a letra e) com resultado de 38\%. Percebemos que nestes dois itens, os alunos apresentaram um menor entendimento do sinal da igualdade com relação ao item anterior (a)) e ao item c) onde também obtivemos percentual favorável com 91\% de acertos no preenchimento dos números faltantes das sentenças. Os baixos índices obtidos nas letras b) e e) indicam a necessidade de discussões de questões semelhantes com relação às turmas investigadas que favoreçam o pensamento relacional, já que as operações utilizadas nas sentenças, adição e subtração simples, entendemos são conhecimentos que já deveriam ter sido consolidados em anos anteriores.

As letras d) e f) remetem a sentenças que explicitam o raciocino relacional da álgebra. Os resultados indicam que no item d) tivemos 6\% de acertos e no item f) nenhum acerto (0\%). Estes dados sinalizam a falta de conhecimentos com relação aos elementos ausentes apresentados nas sentenças, pois estes remetiam a conhecimentos do pensamento algébrico, como possibilidade de relacioná-los com conceitos de número aproximado e estimativa, sem necessitar diretamente do cálculo numérico na identificação do número ausente. É este tipo de pensamento, mais complexos, que requer um grau de abstração mais refinado que é proposto quando discutimos álgebra no nível final do primeiro segmento dos anos iniciais. Segundo Van de Walle (2009) essas questões estimulam o raciocínio e compreensão da estrutura das sentenças algébricas na matemática.

A segunda questão apresentava uma situação-problema onde esperávamos que os alunos realizassem a leitura, a interpretação e a resolução com conceitos do pensamento relacional. Constatamos que, percebemos que as questões com mais

Ao analisarmos a questão 2, referente a resolução de problemas, constatamos que 98\% dos alunos erraram a questão, 1\% respondeu corretamente e 1\% destes não respondeu. Neste momento vários pontos podem ser levados em conta para explicar esse resultado. Um deles, se deve a falta do uso da leitura para ensinar matemática, usando apenas os números, e sempre aparecendo na mesma ordem e usando apenas uma operação para o cálculo. Isso confirma que os alunos não possuem o pensamento relacional, sendo uma ausência em sua formação, além das dificuldades na leitura, interpretação e registro do que se pedia na situação problema. 
Ao analisarmos os dados de forma geral, percebemos que estes remetem à valores que apesar de se tratar de adições e ou subtrações simples indicam que não houve uma compreensão das sentenças e da função do sinal da igualdade na maioria dos itens. Constatamos também que dependendo da posição do número faltante estes resultados mudam de índices drasticamente. Temos como hipóteses que as turmas participantes não estão habituadas a utilizarem algumas sentenças apresentadas no questionário, principalmente a d) e a f). Devemos provocar o aluno a pensar de modo diferente, para que possa entender que é possível chegar a um resultado utilizando outros caminhos que não seja, especificamente o cálculo, como aproximações, arredondamento, estimativas, operações inversas tão necessárias no nosso dia a dia utilizando relações matemáticas.

Os resultados apresentados nas Tabelas 2 e 3 indicaram que os estudantes apresentaram dificuldades na compreensão de elementos ausentes (primeiro e no segundo termo de uma identidade), na compreensão do sinal de igualdade e na resolução de problemas.

\section{CONSIDERAÇÕES FINAIS}

Com intuito de desenvolvermos atividades didáticas voltadas para turmas de 4o e 5ำ anos do Ensino Fundamental e discutir o conceito do pensamento relacional em álgebra, realizamos estudos teóricos e elaboramos atividades diversificadas de ensino com intuito de facilitar a aprendizagem de obrigatórios de álgebra. Elaboramos atividades e realizamos ensaios para identificação de conhecimentos prévios dos participantes com relação à proposta.

Os resultados indicaram que as atividades elaboradas abordam os principais conceitos de álgebra para os anos iniciais do Ensino Fundamental e favoreceram a compreensão dos estudantes quando utilizam materiais manipulativos e consideram o contexto dos participantes com relação ao pensamento relacional. A igualdade de sentenças, o reconhecimento de números faltantes e a compreensão do sinal de igualdade foram as habilidades trabalhadas nas atividades de álgebra e identificadas como necessárias na compreensão dos participantes.

Percebemos ao final do estudo que existiu uma dificuldade de compreensão nas turmas participantes com relação ao pensamento relacional da álgebra nos anos iniciais do Ensino Fundamental. As atividades que foram sugeridas no questionário inicial para verificação, traziam habilidades propostas a partir do $3^{0}$ ano do Ensino Fundamental. Verificamos que as respostas das questões evidenciaram grande dificuldade dos participantes para resolver as questões que exigiam conhecimentos de anos anteriores, como adição e subtração. Dificuldades também nas sentenças com elementos ausentes apontam que os alunos apresentaram confusões e erros no uso do sinal da igualdade.

Como proposta para melhorar os conhecimentos de álgebra, sugerimos a utilização de sequências didáticas como sistematização do conhecimento, juntamente com o uso de materiais concretos nas atividades iniciais, pois estas podem auxiliar na internalização de conceitos, de forma gradativa possibilitando que o aluno consiga realizar registro e a compreensão da matemática na sua forma abstrata.

A experiência que nos foi ofertada, através da realização desta pesquisa, de estar na sala de aula conhecendo, ainda que de modo observatório, este ambiente, nos fez ver o quanto é importante passar o conhecimento aos alunos da maneira que eles possam compreender, respeitando a realidade social de cada um, o conhecimento prévio que trazem pra sala; por outro ponto de vista, ao evidenciarmos o quanto o conhecimento dos professores podem fazer a diferença no processo de ensino-aprendizagem de matemática e com relação ao que se estabelece entre aluno e professor(a).

\section{REFERÊNCIAS}

[1] BRASIL. Ministério da Educação. Base Nacional Comum Curricular. Secretaria de Ensino Fundamental. BRASIL: MEC/SEF, 2017. Disponível em: http://basenacionalcomum.mec.gov.br. Acesso em: Junho/2018.

[2] BRASIL. Constituição Federal de 1988. Disponível em: http://www.planalto.gov.br/ccivil_03/constituicao/constituicao.htm. Acesso em: Julho/2019.

[3] . Ministério da Educação Conselho Nacional de Educação Câmara de Educação Básica. Resolução № 4, de 13 de Julho de 2010. Diretrizes para o Ensino Básico. 2010. SEB/MEC. Disponível em: http://portal.mec.gov.br/index.php?option=com_docman\&view=download\&alias=15548-d-c-n-educacao-basicanova-pdf\&Itemid=30192 Acesso em Junho/2019. 
[4] CADERNO SOMA. Paraíba. Relações numéricas, espaciais e de grandezas - Consolidando - 3o ano. Caderno 1 (Coleção Práticas de Letramentos no Ciclo de Alfabetização). João Pessoa: Editora do CCTA, 2017.

[5] FARIAS, Severina Andréa Dantas de.; AZÊREDO, Maria Alves de; RÊGO Rogéria Gaudencio do. Matemática no Ensino Fundamental: Considerações teóricas e metodológicas. João Pessoa: SADF, 2016.

[6] GIL, A. C. Métodos e técnicas de pesquisa social. 6 edição. São Paulo: Atlas, 2011.

[7] PARAÍBA, Estado. Referenciais Curriculares do Ensino Fundamental do Estado da Paraíba, João Pessoa: SEE/PB, 2010.

[8] VAN DE WALLE, John. A. Matemática no ensino fundamental: formação de professores e aplicação em sala de aula. 6o ed. Porto Alegre: Artmed, 2009. 


\section{Capítulo 18}

\section{Fatores que interferem na motivação para o}

aprendizado da matemática

\section{Ivan Rodrigues de Moura \\ Vilani Ferreira Feitosa Amaral}

Resumo: A presente pesquisa tem a iniciativa de identificar os fatores que interferem na motivação para o aprendizado de Matemática dos alunos do $1^{\circ}$ ano do Ensino Médio do Instituto Federal de Educação, Ciência e Tecnologia (PI) Campus Angical do Piauí-PI. O estudo foi realizado com o contato de maneira direta o público alvo (estudantes do $1^{\circ}$ ano) e a metodologia empregada nesta pesquisa têm como base aplicar um questionário composto por questões subjetivas. Esse questionário terá como principal objetivo revelar os principais fatores que motivam os alunos do ensino médio para aquisição do conhecimento no ensino da Matemática. Pretende-se assim, portanto, relacionar os mesmos fatores com a literatura de motivação e com métodos de instrução da Matemática. Após a análise e interpretação dos dados, confirmamos com o referencial teórico CHIAVENATO(2005), MAXIMILIANO (2007), ROSA (2012), PRODANOV e FREITAS (2013) que é diverso os fatores que interferem na motivação do estudante na disciplina de matemática. Mas podemos identificar que alguns são ditos como principais ou até mesmo indispensáveis em termos de conhecimento.

Palavras-chave: Motivação, Matemática, Alunos. 


\section{INTRODUÇÃO}

A prática de ensino da Matemática na ultima etapa da Educação Básica segue, na grande maioria, métodos tradicionais na ação docente que, muitas vezes, causam a rejeição de grande parte dos estudantes em relação ao conteúdo apresentado. Observa-se que é muito comum o aluno apresentar dificuldades para realizar cálculos e compreender conceitos matemáticos e isso acaba desmotivando-o durante as aulas. Tal situação tem levado a um baixo aproveitamento na aprendizagem de Matemática, contribuindo para a baixa autoestima e também a indisciplina escolar, gerando conflitos entre alunos e professores.

Muitos destes conflitos poderiam ser evitados se houvesse por parte dos professores um estudo mais detalhado sobre a motivação na aprendizagem. Então, é de extrema importância as considerações desta respectiva pesquisa, pois poderá de certa forma contribuir para um melhor aproveitamento e desenvolvimento da aula.

Tais considerações norteiam esse trabalho, cuja investigação apontam os fatores intrínsecos e extrínsecos relacionados a motivação da aprendizagem em Matemática dos alunos do ensino médio. Com isso, pretende-se realizar uma reflexão sobre a relação existente entre a motivação e aprendizagem tomando por base a teorias psicológicas da aprendizagem que favorecem a compreensão da motivação e dos fatores que colaboram na aprendizagem da Matemática.

A motivação tornou-se um aspecto determinante no ambiente escolar e também necessário para o sucesso da aprendizagem. De acordo com Lima "que desencadeia uma ação, que lhe dá direção, mantém seu curso em direção a um objetivo e a finaliza" Winterstein (apoud Lima 2000, p. 149).

Como motivação para este estudo, partimos do seguinte problema: Quais são os principais fatores que motivam os alunos do ensino médio para o aprendizado do Ensino da Matemática?

A respectiva estrutura do trabalho apresenta uma análise da pesquisa e também uma fundamentação em pesquisadores mais experientes sobre o tema da análise. Nele, vai estar à metodologia detalhada de como foi realizado o estudo. Incluindo uma conclusão sobre a ressalva, mostrando os resultados obtidos no decorrer da observação.

\section{JUSTIFICATIVA}

Motivação é um processo responsável por impulso no comportamento do ser humano para uma determinada ação, que o estimula para realizar suas tarefas de forma que o objetivo esperado seja alcançado de forma satisfatória.

De acordo com Robbins (2005) a motivação possui três propriedades que a regem, uma é a direção, o foco da pessoa em sua meta e como realizar, outra é a intensidade, se o objetivo proposto é feito como algo que vai lhe trazer satisfação ou será realizado por obrigação, e a permanência. "A motivação é específica. Uma pessoa motivada para trabalhar pode não ter motivação para estudar ou vice-versa. Não há um estado geral de motivação, que leve uma pessoa a sempre ter disposição para tudo." (MAXIMILIANO, 2007, p.250).

De acordo com Chiavenato (2005), a motivação vai estar sempre relacionada ao comportamento humano, principalmente quando se deseja alcançar algum objetivo, a uma variedade de fatores que poderão influenciar a motivação do individuo, quando o mesmo tem a necessidade de busca de mecanismos para a satisfação ou a garantia de garantir um conforto ou realização, ainda segundo o autor:

"Os seres humanos são motivados por uma grande variedade de fatores. 0 processo motivacional pode ser explicado da seguinte forma: as necessidades e carências provocam tensão e desconforto na pessoa e desencadeiam um processo que busca reduzir ou eliminar a tensão. A pessoa escolhe um curso de ação para satisfazer determinada necessidade ou carência. Se a pessoa consegue satisfazer a necessidade, o processo motivacional é bem-sucedido. Essa avaliação do desempenho determina algum tipo de recompensa ou punição à pessoa." (CHIAVENATO, 2005 p. 273)

Essas considerações referentes à motivação nos levam a entender que o processo motivacional está ligado ao comportamento que o individuo deseja adquirir, ou seja, o que ele busca alcançar. 


\subsection{MOTIVAÇÃO NA DISCIPLINA MATEMÁTICA}

O ensino nas escolas nos obriga a compreender as várias tentativas de incentivar o aluno a aprender os possíveis reflexos na aceitação ou rejeição das tarefas, bem como sua tendência em se perseverar na realização das mesmas. Destacando-se assim, as variáveis indicadas no fator motivacional em sala de aula que tendem a variar ao longo do tempo (SALVADOR, 2000).

Segundo Lima (2000, p.150) "a facilidade com que um aluno aprende pode ser atribuída à motivação, e sua falta é um fator que leva os estudantes à lentidão ou, em casos extremos, à ausência de aprendizagem." Assim notamos que vários autores consideram a motivação uma grande influência no aprendizado do aluno. Pintrich e Schunk (2002) relatam que se pode estabelecer algo entre motivação, aprendizagem e estratégia, ou seja, a aprendizagem influencia a aprendizagem dos alunos.

Sabendo que o professor sempre busca formas para motivar os alunos demonstrando a importância da matemática para o seu futuro independente da carreira profissional que o mesmo deseje, assim tendo que instiga-los a uma serie de exercícios diferenciados como geradores de aprendizagem:

"É bastante comum o aluno desistir de solucionar um problema matemático, afirmando não ter aprendido como resolver aquele tipo de questão ainda, quando ele não consegue reconhecer qual o algoritmo ou processo de solução apropriado para aquele problema. Faltam aos alunos uma flexibilidade de solução e a coragem de tentar soluções alternativas, diferentes das propostas pelos professores" (D'AMBROSIO, 1989, p.1).

Segundo a autora D'Ambrosio, é preciso que os professores façam os alunos pesquisarem sobre a matemática, de modo que eles desenvolvam a criatividade ao se trabalhar com determinadas situações. Também devido às propostas pedagógicas da escola muitas vezes os docentes acabam aplicando todo o conteúdo ao invés de priorizar a qualidade da aprendizagem do discente.

Para que ocorra todo o processo de aprendizagem do aluno é necessário que o professor tenha uma preparação assim organizando as atividades a serem expostas e praticadas de acordo com o apoio da escola assim utilizando os recursos disponibilizados pela mesma. Para Rosa (2012) as aulas mais dinâmicas e diferenciadas do modelo tradicional e expositivo podem ser mais efetivas e gerar mais aprendizado entre os alunos, mesmo que aja dificuldade para os docentes:

"A aprendizagem tanto em aulas realizadas em sala de aula, quanto em aulas diferenciadas, depende de muitos fatores, como motivação, afetividade, estímulo, criatividade, entre vários outros. Por estes motivos, aulas diferenciadas podem ser consideradas uma ótima ferramenta de ensino. (...) os professores encontram dificuldades na execução de certos projetos, como saídas de campo, aulas fora da escola, e até mesmo nas atividades realizadas dentro do colégio. É preciso encontrar uma maneira de minimizar os efeitos desses contratempos que muitas vezes impossibilitam a execução das atividades. Organizar melhor o tempo de aula, e até mesmo o conteúdo, para que seja possível oferecer aos alunos um ensino de qualidade, não depende somente dos professores, mas também de todos os envolvidos direta ou indiretamente no processo de aprendizagem dos alunos, e deve ser pensado e planejado para que possa ser executado" (ROSA, 2012, p. 37-38).

\section{METODOLOGIA}

A pesquisa é de cunho exploratório de abordagem qualitativa, pois se compreende que o método que poderá proporcionar maior conhecimento e familiaridade com o problema.

Pesquisa exploratória é quando a pesquisa se encontra na fase preliminar, tem como finalidade proporcionar mais informações sobre o assunto que vamos investigar, possibilitando sua definição e seu delineamento, isto é, facilitar a delimitação do tema da pesquisa; orientar a fixação dos objetivos e a formulação das hipóteses ou descobrir um novo tipo de enfoque para o assunto. Assume, em geral, as formas de pesquisas bibliográficas e estudos de caso. (PRODANOV e FREITAS, 2013, p. 51-52). 
A metodologia empregada neste artigo com suas respectivas pesquisas têm como base aplicar um questionário composto por questões subjetivas. Esse questionário apresenta o objetivo de revelar os principais fatores que motivam os alunos do ensino médio para o aprendizado do ensino Matemática.

Para a realização da aplicação do questionário houve uma breve explicação sobre o tema abordado para os estudantes mostrando alguns fatores que poderiam influenciar os mesmos a ter interesse no aprendizado matemático, assim verificando as praticas que favoreceram a motivação em sala de aula.

A análise concluída é a partir de questionários, assim demonstrando os reais interesses que levam os alunos a querer estudar Matemática.

\section{RESULTADOS E DISCUSSÃO}

Como uma atividade em sequência à metodologia, esta parte da pesquisa se dedica exclusivamente em prol de verificar os dados coletados do questionário na qual foi aplicado aos alunos do Instituto Federal de Educação, Ciência e Tecnologia do Campus de Angical do Piauí-PI..

0 questionário foi aplicado aos alunos da $1^{\circ}$ série do Ensino Médio que cursam o Técnico em Informática do IFPI Campus Angical. No momento da aplicação do questionário foi realizada uma apresentação pesquisa com seus respectivos objetivos e aspectos metodológicos.

Entre os alunos participantes constatou-se que a maioria foi mulheres, como observamos nos gráficos a seguir:

\section{QUESTÃO 1}

Em relação à distribuição por idade temos os seguintes dados:

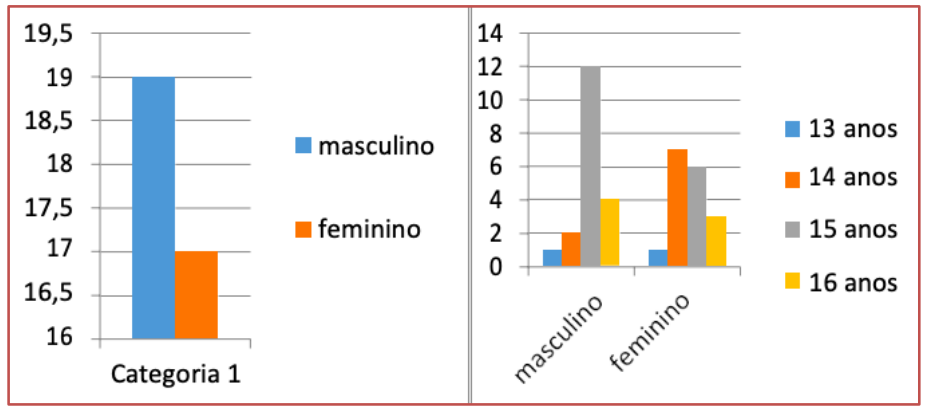

Dados do autor-2018

Terminado as questões em que se referem a sexo e idade, exporemos agora dados no qual fazem importância indispensáveis aos objetivos deste artigo.

As questões no qual foram submetidas aos alunos foram do tipo analítico-expositivas e objetivas. Estas questões tiveram como objetivos principais e diretos identificar e verificar fatores que interferem na motivação dos estudantes. Observaremos agora os dados no qual se referem às questões relacionadas a motivação:

\section{QUESTÃo 2}

A segunda questão foi criada com o objetivo de identificar logo de início a quantidade de alunos que gostam de matemática para eles conseguirem responder com mais segurança as perguntas seguintes. 
2) Você gosta de matemática? Se sim, por quê? Se não, por quê?

\section{QUESTÃO 3}

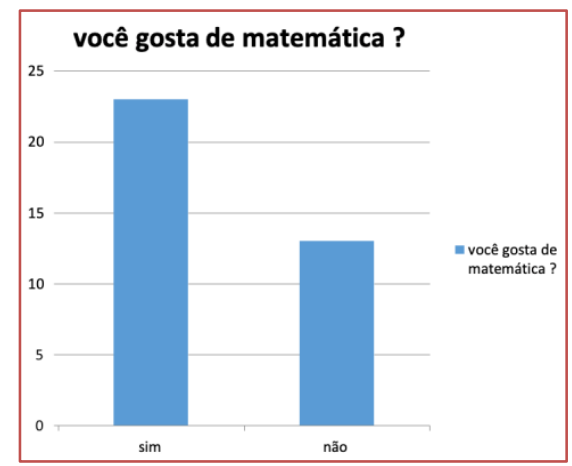

Dados do autor-2018

A terceira questão foi criada com o objetivo de induzir os alunos a fazerem uma avaliação de si mesmo em relação ao aprendizado de matemática. E também de conseguir entender o significado de ser "bom aluno" na concepção deles.

2) Você se considera um bom aluno (a) em matemática? Por quê?

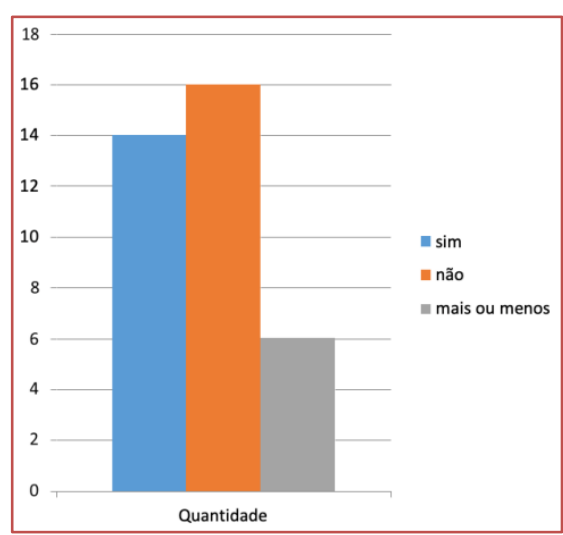

Dados do autor-2018

\section{QUESTÃO 4}

5o Você considera Matemática importante?

A quarta questão foi criada com o objetivo de descobrir a opinião dos alunos sobre a importância da Matemática.

\section{QUESTÕES OBJETIVAS}

\section{QUESTÃO 5}

6) Considerando seus professores de matemática, você percebe que eles:

1-Incentivam os alunos a melhorar

2-Estão disponíveis para esclarecer as dúvidas dos alunos

3-Dão oportunidade aos alunos para exporem opiniões nas aulas

4-Relacionam-se bem com os alunos

5-Continuam a explicar até que todos entendam a matéria

6-Mostram interesse pelo aprendizado de todos os alunos 


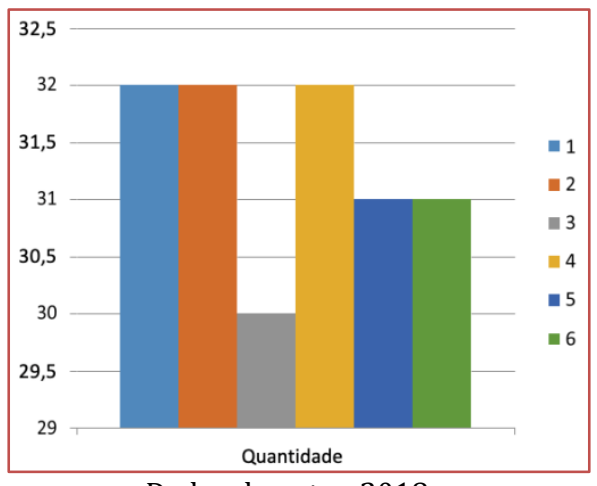

Dados do autor-2018

\section{QUESTÃO 6}

4) Você considera como motivação para estudar matemática:

1- Professores 2-curiosidades 3- desafios 4- importância

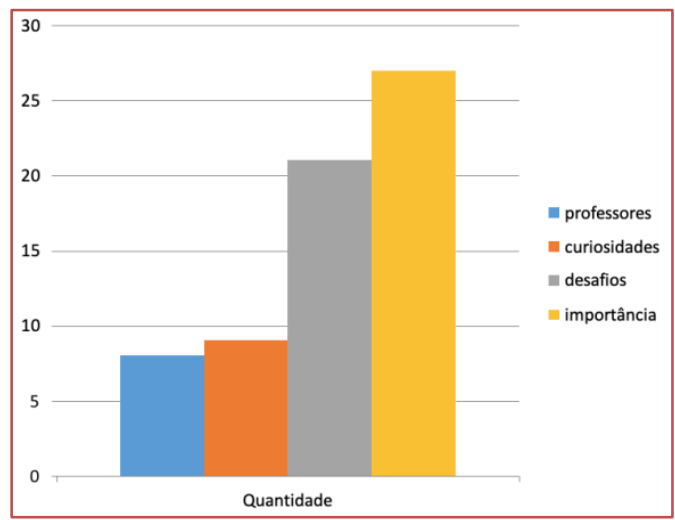

Dados do autor-2018

\section{QUESTÃO 7}

A questão sete é umas das questões principais para o presente projeto, com a conviç̧ão e certeza de que os alunos a responderam com absoluta segurança.

3) Você tem motivação para estudar matemática?

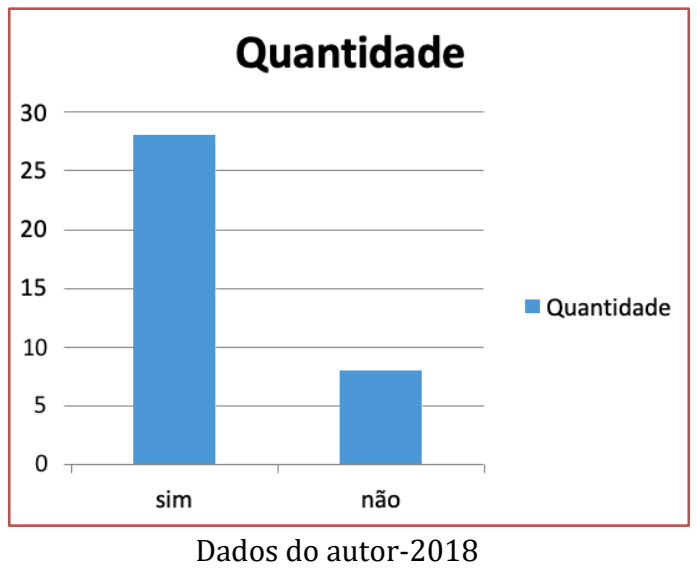


Observamos que a maioria dos alunos no qual foram submetidos ao questionário conseguiu emitir dados que serão indispensáveis para alcançarmos o objeto do estudo.

\section{CONSIDERAÇõES FINAIS}

Após a análise e interpretação dos dados, confirmamos com o referencial teórico que é diverso os fatores que interferem na motivação do estudante para o estudo da Matemática ao longo da trajetória acadêmica dos alunos. Mas podemos identificar que alguns são ditos como principais ou até mesmo indispensáveis em termos de conhecimento.

Com base no estudo o que podemos observar é que para haver um maior e melhor rendimento do aluno no estudo da Matemática é necessário que haja uma didática desde o principio do planejamento voltada para o sentido de mostra-la como ela realmente é para o estudante. Isto implica em aulas dinâmicas e com aplicações, na qual haja a participação de todos os alunos da turma. Além é claro, de enaltecer a sua importância de modo a chamar a atenção do aluno para um maior pensamento crítico em relação à disciplina e, com isso, uma maior motivação para o estudo da mesma.

\section{REFERÊNCIAS}

[1] BZUNECK, J.A. A motivação do aluno: aspectos introdutórios. In: BORUCHOVITCH, E. \& BZUNECK, J. A. (Orgs.). A Motivação do Aluno: contribuições da Psicologia Contemporânea. 4⿳ạa ed. Petrópolis, RJ: Vozes, 2009. P. 9-36

[2] CHIAVENATO, Idalberto. Comportamento Organizacional: a dinâmica do sucesso das organizações. $2^{\circ}$ ed. Rio de Janeiro: Elsevier, 2005.

[3] D’AMBRosio, B. S. Como ensinar matemática hoje? Temas e debates. SBEM. Ano II. N2. Brasília, DF, 1989. P.15-19

[4] LIMA, L. M. S. Motivação em sala de aula: a mola propulsora da aprendizagem. In: SISTO, F. F.; OLIVEIRA, G. C.; FINI, L. D. T. (Org.). Leituras de psicologia para formação de professores. Petrópolis: Vozes, 2000. P.148-160.

[5] MAXIMIANO, Antônio César Amaru. Teoria Geral da Administração: da revolução urbana a revolução digital. 6ㅇe ed. São Paulo: Atlas, 2007.

[6] PINTRICH, P. R.; SCHUNK, D. H. Motivation in education: theory, research and aplications. Upper Saddle River: Prentice Hall, 2002.

[7] PRODANOV, C. C.; FREITAS, E. C. D. Metodologia do trabalho científico: Métodos e Técnicas da Pesquisa e do Trabalho Acadêmico. 2a․ ed. Novo Hamburgo: Universiade Freevale, 2013.

[8] ROBBINS, Steplen P, Comportamento organizacional. 11ํo ed. São Paulo: Pearson Prentice Hall, 2005.

[9] ROSA, A.B. Aula diferenciada e seus efeitos na aprendizagem dos alunos: o que os professores de Biologia têm a dizer sobre isso? - Porto Alegre, 2012. Disponível em:< HTTPS://www.lume.ufrgs.br/bitstream/handle/10183/72356/000872151.pdf?Sequence=1>. Acesso em: 27 Jul.2018.

[10] SALVADOR, C.C. Psicologia do ensino. Porto Alegre: Artes Médicas Sul, 2000. 


\section{Capítulo 19}

\section{Interdisciplinaridade entre Educação Física e Matemática: Construindo conceitos matemáticos através de uma aplicação no Campeonato Francês de Vôlei}

\section{Nicéias Silva Vilela}

\section{Dâmocles Aurélio Nascimento da Silva Alves}

Resumo: Apresentamos por meio deste artigo o resultado de uma pesquisa aplicada ao Campeonato Frances de vôlei 2018/2019, como exemplo de uma metodologia de previsão de resultado das partidas que pode ser utilizado nas unidades escolares, por estudantes da educação básica. Para criação do modelo de previsão, foram necessários inicialmente os dados dos sets marcados e sofridos pelas 13 (treze) equipes da categoria masculina e 14 (quatorze) da categoria feminina, apenas as componentes da Liga A, em que foi recolhido o número de sets marcados e sofridos nas partidas de classificação das integrantes do torneio. Após o término do recolhimento, iniciou-se o processo de calcular um fator ataque e um fator defesa de cada equipe, para aplicar na distribuição de Poisson, com a finalidade de sua aplicação fornecer probabilidades de sets a serem marcados por uma equipe em uma partida do Campeonato Francês, cujo placar mais provável da partida é determinado pela maior probabilidade de sets a serem marcados por cada equipe na disputa. Dessa forma, foi possível prever parte das rodadas, o conjunto amostragem escolhido, e também as fases eliminatórias, sendo as quartas-final, semifinais e finais, em que depois de dada fase ocorrer podia-se prever a seguinte, até encontrar um campeão da categoria masculina e uma campeã da categoria feminina da Liga A do campeonato francês.

Palavras-chave: Interdisciplinaridade, Probabilidade, Vôlei, Poisson. 


\section{INTRODUÇÃO}

Os jogos escolares da juventude no Brasil são divididos em 14 esportes, onde um deles é o Vôlei. Apenas uma escola representa cada estado da federação e estas podem escrever nove alunos-atletas e um técnico. 0 campeonato é organizado na fase classificatória com jogos de 3 sets, onde os dois primeiros sets são de 25 pontos e o terceiro set, quando necessário, de 15 pontos. Nas fases finais os jogos são realizados em melhor de cinco sets. As regras são as mesmas adotadas pela Confederação Brasileira de Vôlei (CBV) e as alturas da rede variam de acordo com a categoria e o sexo. Esse ano a competição será realizada em Natal/RN, no período de 20 a 24 de setembro, nas categorias de 12 a 14 anos e 15 a 17 anos, divididos em masculino e feminino.

Os trabalhos que encontramos na literatura relacionam as disciplinas de educação física e matemática, explorando conteúdo matemático de forma introdutória, como no artigo de Borges e Kieckow, que utilizou um método para ensinar frações com alunos do 6o ano do ensino fundamental. Já no trabalho de Lobato e Almeida (2013), é realizada uma intervenção pedagógica, onde explora regras de jogos com regras e disciplinas na sala de aula. Então objetivando explorar a Estatística e a Educação Física, realizamos pesquisas em busca de dados sobre aos resultados dos sets nos Jogos de Vôlei realizados pelos jogos escolares da juventude no Brasil e não encontramos. Decidimos assim, buscar dados dos campeonatos de vôlei para modelar previsões de resultados e assim disponibilizar um métodos simples para previsão, usando estatística vivenciada na educação básica, como média, divisões e porcentagens.

Buscamos campeonatos que estivessem em andamento para aplicar metodologia de previsão e um dos campeonatos em andamento era o Campeonato Francês. O Campeonato Francês de vôlei é a principal competição entre clubes da França, nas categorias masculina e feminina. 0 torneio é organizado pela Ligue Nationale de Volley (LNV), entidade filiada à Federação Francesa de voleibol (FFVB) que acede o acesso do campeão e vice, da categoria masculina, à Liga dos Campeões da Europa e do terceiro e quarto colocados à Copa CEV.

A disputa é dividida em duas divisórias Liga A e Liga B, ambas formadas pelos melhores jogadores franceses, na qual é composta cada liga por 13 equipes da categoria masculina e 14 equipes da categoria feminina. 0 campeonato é disputado pelos homens desde a temporada de 1937/1938, sendo considerada uma das ligas nacionais mais fortes da Europa, e pelas mulheres desde 1991/1992, essa ocupando a 54 a posição do ranking mundial da FIVB, segundo dados de 6 de outubro de 2015.

Desde as últimas décadas, o vôlei vem se tornando crescente constante preferência de muitos amantes esportivos, nos diversos lugares do mundo. Ou seja, é cada vez mais praticado por grupos de pessoas de diversas faixas etárias como forma de diversão e laser nas horas vagas. Além disso, este também tem conquistado um grande público que acompanha e assiste às partidas das suas equipes favoritas nos inúmeros torneios nacionais e internacionais.

Em virtude dos melhores jogadores constituírem as fortes equipes que participam dos grandes torneios, como: Torneio Olímpico de vôlei, Campeonato Mundial, Copa do Mundo, Liga Mundial, Grand Prix, Copa dos Campeões do Voleibol, Campeonatos Sul-Americanos e Jogos Pan-Americanos; isso deixa os torcedores que são apaixonados pelo vôlei ainda mais empolgados, desencadeando discussões a respeito e até mesmo motivando-os a tentarem adivinhar quem vencerá tal partida.

Perante a paixão nacional pelo vôlei, tencionamos estudar as possibilidades de todas as equipes da Liga A, nas duas categorias, vencerem o torneio. Visto que, para uma equipe se sair bem é necessário estudar estatisticamente a equipe adversária, seja pela sua pontuação em partidas anteriores, número de vitórias e derrotas, se ela se saiu melhor jogando em casa ou fora, até mesmo os sets pró e contra; usufruindo dessa forte correlação entre estatística e vôlei, surgiu a ideia de prever os resultados das partidas de uma das divisórias do campeonato francês de vôlei.

Para isso se elaborou um modelo de previsão, aplicado na distribuição de probabilidades de Poisson, de modo que se calculou a probabilidade de sets a serem marcados por uma equipe em dada partida. Nele foram analisadas as médias de sets das 27 equipes a partir do histórico de classificação, e disso encontraram-se os fatores de ataque e de defesa de cada equipe participante do campeonato, possibilitando a partir desses fatores, encontrar uma média de sets para aplicarmos na distribuição de Poisson. Mais na aplicação verificar no confronto o quantitativo mais provável de sets marcados de cada equipe na disputa, com a porcentagem de ocorrência, e assim determinar o placar mais possível da partida. 
Analisaram-se todos os placares mais prováveis de cada partida, em recorrência disso determinou-se o seu posicionamento para a próxima rodada, e quem seguiria para a etapa seguinte, no caso das quartas, semifinais e finais. Além disso, averiguamos todos os resultados, e corrigimos o empate nas etapas eliminatórias, assegurando que houvesse um vencedor em cada categoria, para isso anotou-se o resultado mais provável de cada disputa, para assim encontrarmos um campeão da Liga A do Campeonato Francês de vôlei.

\section{METODOLOGIA}

Para a previsão das partidas do campeonato Francês de vôlei utilizou-se a Distribuição de Poisson, descoberta em 1838, pelo matemático francês Siméon Denis Poisson. Na qual, essa realiza uma aproximação de probabilidade aplicável a ocorrências de um número de eventos reais, por meio de médias em relação a dado intervalo.

Além disso, trata-se de uma distribuição discreta, de tal modo que o modelo de Poisson pode ser deduzido através do modelo binomial para o caso onde se tem infinitas tentativas. Ou seja, um caso limite de uma função que se desenvolve quando o número de $n$ tentativas aumenta indefinidamente, enquanto o produto $\lambda=n . p$, que é o valor esperado do número de sucessos das tentativas, permanece constante. Dessa forma, considere a função de probabilidade binomial.

$$
\begin{gathered}
p(x)=\mathbb{P}(X=x)=\left(\begin{array}{c}
n \\
x
\end{array}\right) p^{x}(1-p)^{n-x} \\
\longrightarrow p(x)=\mathbb{P}(X=x)=\frac{n !}{x !(n-x) !} p^{x}(1-p)^{n-x}
\end{gathered}
$$

Observe que é possível reescrever a expressão acima da seguinte forma,

$$
\begin{aligned}
\mathbb{P}(X=x) & =\frac{n !}{x !(n-x) !} p^{x} \frac{n^{x}}{n^{x}}\left(1-\frac{n p}{n}\right)^{n-x}=\frac{n !}{x !(n-x) !} \frac{(n p)^{x}}{n^{x}}\left(1-\frac{n p}{n}\right)^{n-x} \longrightarrow \\
& \longrightarrow \mathbb{P}(X=x)=\frac{(n p)^{x}}{x !} \frac{n !}{n^{x}(n-x) !}\left(1-\frac{n p}{n}\right)^{n-x} \longrightarrow \\
\longrightarrow & \mathbb{P}(X=x)=\frac{(n p)^{x}}{x !} \frac{n !}{n^{x}(n-x) !}\left(1-\frac{n p}{n}\right)^{n}\left(1-\frac{n p}{n}\right)^{-x}
\end{aligned}
$$

e tomando $\lambda=$ n.p, segue que

$$
\mathbb{P}(X=x)=\frac{\lambda^{x}}{x !} \frac{n !}{n^{x}(n-x) !}\left(1-\frac{\lambda}{n}\right)^{n}\left(1-\frac{\lambda}{n}\right)^{-x}
$$

A expressão pode ser separada para assim avaliarmos os limites quando $n$ tende ao infinito. Sendo assim, 


$$
\lim (n \rightarrow \infty) \frac{n !}{n^{x}(n-x) !}=\lim (n \rightarrow \infty)\left\{\frac{n(n-1) \cdots(n-x+1)}{x !}\right\}=1
$$

$$
\lim (n \rightarrow \infty)\left(1-\frac{\lambda}{n}\right)^{n}=e^{-\lambda}
$$

$$
\lim (n \rightarrow \infty)\left(1-\frac{\lambda}{n}\right)^{-x}=1
$$

Substituindo (I), (II) e (III) na expressão, temos

$$
\lim _{n \rightarrow \infty} \mathbb{P}(X=x)=\frac{e^{-\lambda} \lambda^{x}}{x !}
$$

Em que $\lambda$ representa o número estimado de ocorrências num certo intervalo de tempo e $x$ representa um inteiro não negativo que esperamos do qual encontrar a ocorrência de sua probabilidade na expressão.

Aplicando-a na condição do Campeonato Francês de vôlei, elaboramos um modelo a partir desta, associando a média $\lambda$ com a relação das capacidades de ataque e defesa de cada equipe. Enquanto a $x$, esse representa a quantidade de sets que uma equipe pode marcar em uma partida, também foi calculada em cada caso, a probabilidade de ocorrência dessa quantidade de sets para cada equipe em todas as partidas da Liga A do campeonato, das duas categorias.

\section{DESCRIÇÃO DO MÉTODO}

Para isso, foi utilizado como base o desempenho das equipes participantes do campeonato, as componentes da Liga A, nas partidas jogadas para a classificação das integrantes do torneio.

Como já mencionado anteriormente, a média de $\lambda$ foi obtida a partir das relações do fator ataque e fator defesa das equipes, ao decorrer dessa descrição está detalhado o processo para encontrar tais fatores. Dispondo como dados, através do espaço de pesquisa, o desempenho das equipes participantes do campeonato foi utilizado para calculá-los, em que houve a extração da média de sets marcados e sofridos de cada equipe nas partidas de classificação para o torneio, dividida pela média de sets marcados e sofridos por todas as equipes.

Tomemos como exemplo o cálculo do fator ataque e fator defesa da Montpellier, equipe da categoria masculina:

Nas 22 partidas jogadas pela Montpellier para a classificação das equipes do torneio, ela marcou 52 sets e sofreu 33 sets:

Em virtude disso, a média de sets marcados pelo Montpellier é a razão entre os sets marcados e o total de partidas jogadas: $52 / 22=2,36364$, e a média de sets sofridos é a razão entre os sets sofridos e o total de partidas jogadas: $33 / 22=1,50$. 
Contudo, ainda não é o suficiente, precisamos dos dados gerais de todas as equipes, em que elas disputaram nas partidas para a classificação no torneio. Foram 288 partidas, marcaram 534 sets e sofreram 534 sets, por consequência a média de sets marcados foi: 534/288 = 1,85417, de forma análoga, a média de sets sofridos foi: $534 / 288=1,85417$.

A partir desses dados, podemos calcular o fator ataque (FA) e o fator defesa (FD) da equipe Montpellier. Vejamos:

- $\quad \mathrm{FA}=$ média de sets marcados pela Montpellier/média de sets marcados pelas equipes

$2,36364 / 1,85417=1,27478$

- $\quad \mathrm{FD}=$ média de sets sofridos pela Montpellier/média de sets sofridos pelas equipes $1,50 / 1,85417=0,80899$

Dessa forma, depois de calcular os fatores de ataque e defesa de todas as equipes da Liga A, seguimos para a etapa das previsões das partidas do campeonato, em que calculamos a média $\lambda$, que será usada no cálculo do quantitativo de sets que uma equipe poderá marcar na sua adversária, pela distribuição de Poisson.

Acerca de todas as partidas da Liga A do campeonato, o enfrentamento entre as equipes $m$ e $n$, a obtenção da média para $m$ resultará do produto do fator de ataque de $m\left(\mathrm{FA}_{\mathrm{m}}\right)$ com o fator de defesa de $\mathrm{n}\left(\mathrm{FD}_{\mathrm{n}}\right)$, e a média para $n$ será obtida pelo produto do fator de ataque de $n\left(F A_{n}\right)$ com fator de defesa de $m\left(F D_{m}\right)$.

Vejamos como exemplo, a primeira partida da equipe Ajaccio contra Chaumont, na rodada 25, em que usaremos a média $\lambda$ para prever o número de sets da Ajaccio:

$\lambda$ Ajaccio $=$ FA Ajaccio $*$ FD Chaumont $=1,5334915940$

Finalizada essa parte, obtivemos a previsão de sets da Ajaccio para prevermos a partida e alcançar o placar mais provável entre as equipes, mas antes é necessário calcular a média $\lambda$ para previsão de sets da Chaumont na disputa, dada pelo processo a seguir:

$\lambda$ Chaumont $=$ FA Chaumont $*$ FD Ajaccio $=0,5528261232$

Tal como vimos anteriormente, obtivemos mutuamente a média para previsão de sets da Ajaccio contra a Chaumont, e em seguida aplicamos na fórmula da distribuição de Poisson, com uma variância de $k=$ $(0,1,2, \ldots, 5)$, correspondente ao número de sets, para calcular a probabilidade de ocorrência em cada situação. Tendo como exemplo, se substituirmos $k=0$ na fórmula, com a média da Ajaccio, obteremos a probabilidade da mesma marcar nenhum set na Chaumont, dessa forma calculamos a probabilidade até um possível 3 sets marcados pela Ajaccio contra a Chaumont.

A seguir apresentamos as probabilidades obtidas em todas as partidas das rodadas analisadas da categoria masculina e da feminina, respectivamente.

\section{RESULTADOS}

\subsection{CATEGORIA MASCULINA}

- $\quad$ Rodada 25: Nessa primeira rodada analisada, composta por 6 partidas, prevíamos 4 vitórias para as equipes mandantes (de casa), e 2 vitórias para as equipes visitantes.

Em vista das partidas das observadas, percebemos que apenas a $1^{\text {a }}$ partida não saiu como previsto, porém, nas demais a modelagem funcionou precisamente. Podemos verificar todas as informações detalhadamente nas duas tabelas abaixo:

Tabela 1: Médias para previsão da probabilidade de sets entre as respectivas equipes de cada partida.

MANDANTE
\begin{tabular}{|c|c|c|c|c|}
\hline Sète & 0,85 & $\mathbf{3 X} \mathbf{1}$ & 1,14 & VISITANTE \\
\hline Nice & 1,75 & $\mathbf{3 X} \mathbf{0}$ & 0,47 & Tourtiers \\
\hline Ajaccio & 1,53 & $\mathbf{3 X} \mathbf{1}$ & 0,55 & Chaumont \\
\hline Cannes & 0,56 & $\mathbf{2 X} \mathbf{3}$ & 1,66 & Tours \\
\hline Montpellier & 1,23 & $\mathbf{3 X} \mathbf{0}$ & 0,66 & Rennes \\
\hline Nantes & 1,80 & $\mathbf{3 X} \mathbf{0}$ & 0,31 & Toulouse \\
\hline
\end{tabular}


Tabela 2: Dados apresentados no espaço de pesquisa.

\begin{tabular}{|cllc|}
\hline \multicolumn{2}{ll}{ Rodada 25} & & \\
\hline $05.04 .14: 30$ & Sète & Poitiers & $3: 1$ \\
\hline $05.04 .15: 00$ & Nice & Tourcoing & $3: 0$ \\
\hline $06.04 .15: 00$ & Ajaccio & Chaumont & $3: 1$ \\
\hline $06.04 .15: 00$ & Cannes & Tours & $2: 3$ \\
\hline $06.04 .15: 00$ & Montpellier & Rennes & $3: 0$ \\
\hline $05.04 .15: 00$ & Nice & Tourcoing & $3: 0$ \\
\hline
\end{tabular}

- Rodada 26: Nessa rodada analisada, composta por 6 partidas, prevíamos que as equipes vencedoras, de todas as partidas, seriam as mandantes.

Perante todas as informações observadas a respeito da rodada, concluímos que apenas a 4 a partida não saiu como previsto, porém, nas demais a modelagem funcionou satisfatoriamente. É possível analisar essas informações detalhadamente nas duas tabelas a seguir:

Tabela 3: Médias para previsão da probabilidade de sets entre as respectivas equipes de cada partida.

\begin{tabular}{|c|c|c|c|c|}
\hline MANDANTE & & LACA & & VISITANTE \\
\hline Chaumont & 1,94 & $3 \mathbf{X 1}$ & 0,26 & Cannes \\
\hline Poiteirs & 1,01 & 3X0 & 0,87 & Nice \\
\hline Rennes & 1,74 & $3 \mathbf{X 0}$ & 0,50 & Nantes \\
\hline Toulouse & 1,38 & $2 \times 3$ & 1,00 & Narbonne \\
\hline Tourcoing & 1,59 & $3 \times 1$ & 0,20 & Sète \\
\hline Tours & 1,67 & 3X0 & 0,32 & Montpellier \\
\hline
\end{tabular}

Tabela 4: Dados apresentados no espaço da pesquisa

\begin{tabular}{|c|c|c|c|}
\hline \multicolumn{4}{|l|}{ Rodada 26} \\
\hline 13.04. $15: 00$ & Chaumont & Cannes & $3: 1$ \\
\hline 13.04. $15: 00$ & Poitiers & Nice & $3: 0$ \\
\hline 13.04. $15: 00$ & Rennes & Nantes & $3: 0$ \\
\hline 13.04. $15: 00$ & Toulouse & Narbonne & $2: 3$ \\
\hline 13.04. $15: 00$ & Tourcoing & Sète & $3: 1$ \\
\hline 13.04. 15:00 & Tours & Montpellier & $3: 1$ \\
\hline
\end{tabular}

- Quartas-final: Nessa fase eliminatória, composta por 9 partidas, prevíamos que 8 vitórias seriam para as equipes de casa e 1 para as equipes visitantes.

A partir das informações apresentadas a respeito dessa rodada, vimos que apenas a $1^{\underline{a}}$ e $8^{\underline{a}}$ partida não saiu como previsto, mas, nas demais a modelagem funcionou corretamente. Podemos analisar essas informações detalhadamente nas duas tabelas a seguir:

Tabela 5: Médias para previsão da probabilidade de sets entre as respectivas equipes de cada partida.

\begin{tabular}{|c|c|c|c|c|}
\hline MANDANTE & & PLACAR & & VISITANTE \\
\hline Poiteirs & 1,06 & $2 \times 3$ & 0,97 & Ajaccio \\
\hline Chaumont & 1,31 & $3 \times 0$ & 0,95 & Montpellier \\
\hline Nantes & 0,90 & $1 \times 3$ & 1,15 & Tours \\
\hline Nice & 1,10 & $3 \mathrm{X1}$ & 0,72 & Rennes \\
\hline Ajaccio & 1,53 & $3 \times 0$ & 0,46 & Poiteirs \\
\hline Montpellier & 1,59 & $0 \times 3$ & 0,66 & Chaumont \\
\hline Rennes & 1,46 & $3 \times 0$ & 0,69 & Nice \\
\hline Tours & 1,98 & $3 \times 0$ & 0,19 & Nantes \\
\hline Nice & 1,10 & $3 \times 1$ & 0,72 & Rennes \\
\hline
\end{tabular}


Tabela 6: Dados apresentados no espaço de pesquisa.

\begin{tabular}{|c|c|c|c|c|}
\hline \multicolumn{5}{|l|}{ Quartos-final } \\
\hline 19.04. 14:30 & Poitiers & Ajaccio & $2: 3$ & \\
\hline 19.04. 15:00 & Chaumont & Montpellier & $3: 0$ & \\
\hline 19.04. $15: 00$ & Nantes & Tours & $1: 3$ & \\
\hline 19.04. $15: 00$ & Nice & Rennes & $3: 1$ & \\
\hline 23.04. $15: 00$ & 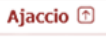 & Poitiers & $3: 0$ & (i) \\
\hline 23.04. $15: 00$ & Montpellier & Chaumont $(\uparrow$ & $0: 3$ & (1) \\
\hline 23.04. $15: 00$ & Rennes & Nice & $3: 0$ & (i) \\
\hline 23.04. 15:00 & Tours $(1)$ & Nantes & $3: 0$ & (i) \\
\hline 19.04. 15:00 & Nice & Rennes & $3: 1$ & \\
\hline
\end{tabular}

- Semi-final: Nessa fase eliminatória, composta por 5 partidas, prevíamos que as equipes vencedoras, de cada partida, seriam as mandantes.

Em vista das partidas ocorridas, observamos que apenas a $1^{\text {a }}$ e $5^{\underline{a}}$ partida não saiu como previsto, porém, nas demais a modelagem funcionou precisamente. É possível verificar essas informações em detalhes nas duas tabelas a seguir:

Tabela 7: Médias para previsão da probabilidade de sets entre as respectivas equipes de cada partida.

MANDANTE
\begin{tabular}{|c|c|ccc|}
\hline PLACAR & \multicolumn{1}{c|}{ VISITANTE } \\
\hline Nice & 0,97 & $\mathbf{2 X 3}$ & 0,94 & Tours \\
\hline Chaumont & 1,37 & $\mathbf{3 X 0}$ & 0,87 & Ajaccio \\
\hline Tours & 1,67 & $\mathbf{3 X 0}$ & 0,26 & Nice \\
\hline Ajaccio & 1,53 & $\mathbf{3 X 1}$ & 0,55 & Chaumont \\
\hline Ajaccio & 1,53 & $\mathbf{1 X 3}$ & 0,55 & Chaumont \\
\hline
\end{tabular}

Tabela 8: Dados apresentados no espaço de pesquisa.

\begin{tabular}{|cllc|}
\hline \multicolumn{1}{|l|}{ Semi-finais } & & & \\
\hline 27.04. $15: 00$ & Nice & Tours & $2: 3$ \\
\hline $28.04 .12: 00$ & Chaumont & Ajaccio & $3: 0$ \\
$02.05 .15: 00$ & Tours $\uparrow$ & Nice & $3: 0$ \\
\hline $02.05 .15: 00$ & Ajaccio & Chaumont & $3: \mathbf{1}$ \\
\hline $03.05 .15: 00$ & Ajaccio & Chaumont $\uparrow$ & $\mathbf{1}: \mathbf{3}$ \\
\hline
\end{tabular}

- $\quad$ Final: Nessa última fase eliminatória, composta por 2 partidas, prevíamos ambas as vitórias para a equipe Tours, ou seja, ela seria a campeã.

Diante todas as informações verificadas a respeito dessa última fase, concluímos que a modelagem funcionou precisamente, e conseguiu prever corretamente a campeã do campeonato, da categoria masculina. Podemos verificar essas informações em detalhes nas duas tabelas abaixo:

Tabela 9: Médias para previsão da probabilidade de sets entre as respectivas equipes de cada partida.

\begin{tabular}{|} 
MANDANTE & \multicolumn{3}{c}{ PLACAR } & \multicolumn{1}{c|}{ VISITANTE } \\
\begin{tabular}{|c|c|c|c|c|}
\hline Chaumont & 0,94 & $\mathbf{1 X 3}$ & 1,30 & Tours \\
\hline Tours & 1,75 & $\mathbf{3 X} 1$ & 0,33 & Chaumont \\
\hline
\end{tabular}
\end{tabular}

Tabela 10: Dados apresentados no espaço de pesquisa.

\begin{tabular}{|c|c|c|}
\hline \multicolumn{3}{|l|}{ Final } \\
\hline 07:05.15:45 Chaumont & Tours & $2: 3$ \\
\hline 10.05: 15:45Tours (1) & Chaumont & $3: 0$ \\
\hline
\end{tabular}




\subsection{CATEGORIA FEMININA}

- $\quad$ Rodada 23: Nessa primeira rodada analisada, composta por 7 partidas, prevíamos 4 vitórias para as equipes mandantes (de casa), e 3 vitórias para as equipes visitantes.

Perante todas as informações analisadas a respeito dessa rodada, vimos que apenas a $4^{a}$, $5^{\underline{a}}$ e $7^{\underline{a}}$ partida não saiu como previsto, porém, nas demais a modelagem funcionou corretamente. É possível verificar essas informações detalhadamente nas duas tabelas seguintes:

Tabela 11: Médias para previsão da probabilidade de sets entre as respectivas equipes de cada partida.

\begin{tabular}{|c|c|c|c|c|}
\hline MANDANTE & \multicolumn{3}{|c|}{ PLACAR } & VISITANTE \\
\hline Le Cannet $\mathrm{M}$ & 1,45 & $3 \times 1$ & 0,71 & Paris M \\
\hline Chamalierois M & 0,52 & $\mathbf{0 \times 3}$ & 1,06 & Marcq Baroeul M \\
\hline France Avenir $2024 \mathrm{M}$ & 0,13 & $\mathbf{0 \times 3}$ & 2,26 & RC Cannes M \\
\hline Vandoeuvre $\mathrm{M}$ & 1,10 & $2 \times 3$ & 1,04 & Venelles M \\
\hline Nantes $\mathbf{M}$ & 0,61 & $3 \times 2$ & 1,04 & Mulhouse M \\
\hline Mougins $\mathbf{M}$ & 1,32 & $3 \times 1$ & 0,20 & Quimper M \\
\hline Beziers M & 1,18 & $\mathbf{0 X 3}$ & 0,71 & Saint-Raphael M \\
\hline
\end{tabular}

Tabela 12: Médias para previsão da probabilidade de sets entre as respectivas equipes de cada partida.

\begin{tabular}{|cllc|}
\hline \multicolumn{1}{|l|}{ Rodada 23 } & & & \\
\hline $05.04 .15: 00$ & Le Cannet M & Paris M & $3: 1$ \\
\hline $05.04 .15: 00$ & Chamalierois M & Marcq Baroeul M & $0: 3$ \\
\hline $06.04 .10: 00$ & France Avenir 2024 M & RC Cannes M & $0: 3$ \\
\hline $06.04 .15: 00$ & Vandoeuvre M & Venelles M & $2: 3$ \\
\hline $06.04 .15: 00$ & Nantes M & Mulhouse M & $3: 2$ \\
\hline $06.04 .15: 00$ & Mougins M & Quimper M & $3: 1$ \\
\hline $06.04 .15: 30$ & Beziers M & Saint-Raphael M & $0: 3$ \\
\hline
\end{tabular}

- $\quad$ Rodada 24: Nessa rodada analisada, composta por 7 partidas, prevíamos 3 vitórias para as equipes mandantes (de casa), e 4 vitórias para as equipes visitantes.

Em vista das partidas que foram vistas, observamos que apenas a $5^{\text {a }}$ partida não saiu como previsto, contudo, nas demais a modelagem funcionou precisamente. Podemos analisar essas informações detalhadamente nas duas tabelas a seguir:

Tabela 13: Médias para previsão da probabilidade de sets entre as respectivas equipes de cada partida.

\begin{tabular}{|} 
MANDANTE \\
\begin{tabular}{|c|c|c|c|c|}
\hline Venelles $\mathbf{M}$ & 1,76 & $\mathbf{3 X} \mathbf{1}$ & 0,18 & France Avenir 2024 M \\
\hline Saint-Raphael M & 0,86 & $\mathbf{2 X} 3$ & 1,13 & Nantes $\mathbf{M}$ \\
\hline Quimper $\mathbf{M}$ & 1,04 & $\mathbf{3 X} \mathbf{1}$ & 0,88 & Vandoeuvre M \\
\hline Marcq Baroeul M & 1,08 & $\mathbf{2 X} \mathbf{3}$ & 1,08 & Mougins $\mathbf{M}$ \\
\hline RC Cannes $\mathbf{M}$ & 0,73 & $\mathbf{3 X} \mathbf{2}$ & 0,82 & Le Cannet M \\
\hline Mulhouse $\mathbf{M}$ & 1,80 & $\mathbf{3 X} \mathbf{0}$ & 0,05 & Paris M \\
\hline Chamalierois M & 0,63 & $\mathbf{0 X} \mathbf{3}$ & 1,22 & Beziers $\mathbf{M}$ \\
\hline
\end{tabular}
\end{tabular}

Tabela 14: Dados apresentados no espaço de pesquisa.

\begin{tabular}{|c|c|c|c|c|c|c|c|}
\hline Rodada 24 & & & & & & & \\
\hline \multirow{2}{*}{ 12.04. 15:00 } & Venelles $M$ & 3 & 25 & 25 & 18 & 25 & \\
\hline & France Avenir $2024 \mathrm{M}$ & 1 & 14 & 18 & 25 & 20 & \\
\hline \multirow{2}{*}{ 12.04. 15:00 } & Saint-Raphael M & 2 & 25 & 25 & 22 & 16 & 14 \\
\hline & Nantes M & 3 & 13 & 23 & 25 & 25 & 16 \\
\hline \multirow{2}{*}{ 12.04. 15:00 } & Quimper M & 3 & 25 & 23 & 25 & 25 & \\
\hline & Vandoeuvre $\mathrm{M}$ & 1 & 21 & 25 & 17 & 22 & \\
\hline \multirow{2}{*}{ 12.04. 15:00 } & Marcq Baroeul M & 2 & 19 & 16 & 25 & 25 & 14 \\
\hline & Mougins M & 3 & 25 & 25 & 17 & 21 & 16 \\
\hline \multirow{2}{*}{ 13.04. 14:00 } & RC Cannes M & 3 & 25 & 20 & 25 & 23 & 15 \\
\hline & Le Cannet $M$ & 2 & 23 & 25 & 15 & 25 & 12 \\
\hline \multirow{2}{*}{ 13.04. 15:00 } & Mulhouse M & 3 & 25 & 25 & 25 & & \\
\hline & Paris M & 0 & 13 & 21 & 17 & & \\
\hline \multirow{2}{*}{ 13.04. 15:00 } & Chamalierois $\mathrm{M}$ & 0 & 20 & 21 & 25 & & \\
\hline & Beziers M & 3 & 25 & 25 & 27 & & \\
\hline
\end{tabular}


- $\quad$ Rodada 25: Nessa rodada analisada, composta por 7 partidas, prevíamos 4 vitórias para as equipes mandantes (de casa), e 3 vitórias para as equipes visitantes.

A partir das informações mostradas a respeito dessa rodada, analisamos que apenas a $3^{\mathbf{a}}$, 6 ${ }^{\underline{a}}$ e $7^{\mathbf{a}}$ partida não saiu como previsto, mas, nas demais a modelagem funcionou satisfatoriamente. Vejamos tais informações detalhadamente nas duas tabelas abaixo:

Tabela 15: Médias para previsão da probabilidade de sets entre as respectivas equipes de cada partida.

\begin{tabular}{|c|c|c|c|c|}
\hline MANDANTE & & LACA & & VISITANTE \\
\hline France Avenir $2024 \mathrm{M}$ & 0,29 & $0 \times 3$ & 1,17 & Marcq Baroeul M \\
\hline Le Cannet $M$ & 1,82 & $3 \times 1$ & 0,13 & Quimper M \\
\hline Mougins $\mathrm{M}$ & 1,22 & $0 \times 3$ & 0,97 & Beziers M \\
\hline Mulhouse M & 1,58 & 3X0 & 0,05 & Saint-Raphael M \\
\hline Nantes $M$ & 0,67 & $0 \times 3$ & 1,01 & RC Cannes $\mathbf{M}$ \\
\hline Paris M & 1,14 & $3 \times 2$ & 1,24 & Venelles M \\
\hline Vandoeuvre $\mathrm{M}$ & 1,27 & $2 \times 3$ & 0,80 & Chamalierois M \\
\hline
\end{tabular}

Tabela 16: Dados apresentados no espaço de pesquisa.

\begin{tabular}{|c|c|c|c|c|c|c|c|}
\hline Rodada 25 & & & & & & & \\
\hline \multirow{2}{*}{ 16.04. 15:00 } & France Avenir $2024 \mathrm{M}$ & 0 & 20 & 13 & 20 & & \\
\hline & Marcq Baroeul M & 3 & 25 & 25 & 25 & & \\
\hline \multirow{2}{*}{ 16.04. 15:00 } & Le Cannet M & 3 & 25 & 23 & 25 & 25 & \\
\hline & Quimper $M$ & 1 & 21 & 25 & 21 & 15 & \\
\hline \multirow{2}{*}{ 16.04. 15:00 } & Mougins M & 0 & 17 & 20 & 9 & & \\
\hline & Beziers M & 3 & 25 & 25 & 25 & & \\
\hline \multirow{2}{*}{ 16.04. 15:00 } & Mulhouse M & 3 & 25 & 25 & 25 & & \\
\hline & Saint-Raphael M & 0 & 11 & 20 & 23 & & \\
\hline \multirow{2}{*}{ 16.04. 15:00 } & Nantes $M$ & 0 & 13 & 18 & 19 & & \\
\hline & RC Cannes $M$ & 3 & 25 & 25 & 25 & & \\
\hline \multirow{2}{*}{ 16.04. 15:00 } & Paris M & 3 & 23 & 23 & 27 & 25 & 15 \\
\hline & Venelles $M$ & 2 & 25 & 25 & 25 & 22 & 10 \\
\hline \multirow{2}{*}{ 16.04. 15:00 } & Vandoeuvre $\mathrm{M}$ & 2 & 14 & 21 & 25 & 34 & 12 \\
\hline & Chamalierois M & 3 & 25 & 25 & 12 & 32 & 15 \\
\hline
\end{tabular}

- $\quad$ Rodada 26: Nessa rodada analisada, composta por 7 partidas, prevíamos 4 vitórias para as equipes mandantes (de casa), e 3 vitórias para as equipes visitantes.

Em vista das partidas que foram vistas, observamos que apenas a $3^{\underline{a}}$ partida não saiu como previsto, contudo, nas demais a modelagem funcionou perfeitamente. É possível verificar detalhadamente nas duas tabelas seguintes:

Tabela 17: Médias para previsão da probabilidade de sets entre as respectivas equipes de cada partida.

MANDANTE
\begin{tabular}{|c|c|c|c|c|}
\hline Beziers M & 1,01 & $\mathbf{3 X 0}$ & 0,78 & Nantes M \\
\hline Chamalierois M & 0,23 & $\mathbf{0 X 3}$ & 2,04 & Le Cannet M \\
\hline Marcq Baroeul M & 1,03 & $\mathbf{3 X 1}$ & 1,13 & Paris M \\
\hline Quimper M & 1,19 & $\mathbf{3 X 0}$ & 0,27 & France Avenir 2024 M \\
\hline RC Cannes M & 1,81 & $\mathbf{3 X 1}$ & 0,52 & Mougins M \\
\hline Saint-Raphael M & 1,29 & $\mathbf{3 X 1}$ & 0,59 & Vandoeuvre M \\
\hline Venelles M & 0,52 & $\mathbf{1 X 3}$ & 1,41 & Mulhouse $\mathbf{M}$ \\
\hline
\end{tabular}


Tabela 18: Dados apresentados no espaço de pesquisa.

\begin{tabular}{|c|c|c|c|c|c|c|}
\hline \multicolumn{7}{|l|}{ Rodada 26} \\
\hline \multirow{2}{*}{ 20.04. 15:00 } & Beziers $\mathrm{M}$ & 3 & 25 & 28 & 25 & \\
\hline & Nantes M & 0 & 20 & 26 & 23 & \\
\hline \multirow{2}{*}{ 20.04. 15:00 } & Chamalierois M & 0 & 17 & 23 & 16 & \\
\hline & Le Cannet M & 3 & 25 & 25 & 25 & \\
\hline \multirow{2}{*}{ 20.04. 15:00 } & Marcq Baroeul M & 3 & 26 & 24 & 25 & 25 \\
\hline & Paris M & 1 & 24 & 26 & 23 & 21 \\
\hline \multirow{2}{*}{ 20.04. 15:00 } & Quimper M & 3 & 25 & 25 & 25 & \\
\hline & France Avenir $2024 \mathrm{M}$ & 0 & 18 & 19 & 21 & \\
\hline \multirow{2}{*}{ 20.04. 15:00 } & RC Cannes M & 3 & 25 & 23 & 26 & 25 \\
\hline & Mougins $M$ & 1 & 21 & 25 & 24 & 14 \\
\hline \multirow{2}{*}{ 20.04. 15:00 } & Saint-Raphael M & 3 & 39 & 20 & 25 & 26 \\
\hline & Vandoeuvre $\mathrm{M}$ & 1 & 37 & 25 & 23 & 24 \\
\hline \multirow{2}{*}{ 20.04. 15:00 } & Venelles $M$ & 1 & 14 & 21 & 25 & 11 \\
\hline & Mulhouse M & 3 & 25 & 25 & 23 & 25 \\
\hline
\end{tabular}

- Quartas-final: Nessa fase eliminatória, composta por 10 partidas, prevíamos 7 vitórias para as equipes mandantes (de casa), e 3 vitórias para as equipes visitantes.

Recorrente as informações vistas a respeito dessa rodada, concluímos que apenas a $1 \stackrel{\text { a }}{\underline{a}} 2^{\underline{a}}$ e $6^{\underline{a}}$ partida não saiu como previsto, contudo, nas demais a modelagem funcionou corretamente. É possível observar essas informações detalhadamente nas duas tabelas a seguir:

Tabela 19: Médias para previsão da probabilidade de sets entre as respectivas equipes de cada partida.

\begin{tabular}{|c|c|c|c|c|}
\hline \multicolumn{2}{|l|}{ MANDANTE } & \multicolumn{2}{|c|}{ PLACAR } & VISITANTE \\
\hline Marcq Baroeul M & 0,39 & $3 \times 0$ & 1,77 & Mulhouse M \\
\hline Saint-Raphael M & 0,48 & $3 \mathbf{X} 0$ & 1,37 & RC Cannes M \\
\hline Venelles M & 0,57 & $1 \mathrm{X} 3$ & 1,36 & Le Cannet M \\
\hline Beziers M & 1,01 & $3 \times 1$ & 0,78 & Nantes M \\
\hline Le Cannet M & 1,38 & $3 \times 1$ & 0,84 & Venelles M \\
\hline Mulhouse M & 1,71 & $2 \times 3$ & 0,04 & Marcq Baroeul M \\
\hline Nantes $\mathbf{M}$ & 1,86 & $3 \times 0$ & 0,60 & Beziers M \\
\hline RC Cannes M & 1,53 & $3 \times 0$ & 0,62 & Saint-Raphael M \\
\hline Nantes $\mathbf{M}$ & 1,86 & $3 \times 0$ & 0,60 & Beziers M \\
\hline RC Cannes M & 1,53 & $3 \times 1$ & 0,62 & Saint-Raphael M \\
\hline
\end{tabular}

Tabela 20: Dados apresentados no espaço de pesquisa.

\begin{tabular}{|c|c|c|c|c|c|c|c|c|}
\hline Quartos-final & & & & & & & & \\
\hline \multirow{2}{*}{ 28.04. $14: 00$} & Nantes $\mathrm{M}$ 1 & 3 & 25 & 25 & 25 & & & \multirow{2}{*}{ (i) } \\
\hline & Beziers $M$ & $\mathbf{0}$ & 21 & 15 & 21 & & & \\
\hline \multirow{2}{*}{ 28.04. $12: 00$} & RC Cannes $\mathrm{M}$ 田 & 3 & 25 & 25 & 21 & 25 & & \multirow{2}{*}{ (1) } \\
\hline & Saint-Raphael M & 1 & 20 & 21 & 25 & 21 & & \\
\hline \multirow{2}{*}{ 27.04. $15: 00$} & Le Cannet M 수 & 3 & 25 & 25 & 20 & 25 & & \multirow{2}{*}{ (1) } \\
\hline & Venelles $\mathrm{M}$ & 1 & 22 & 20 & 25 & 14 & & \\
\hline \multirow{2}{*}{ 27.04. $15: 00$} & Mulhouse M & 2 & 23 & 23 & 25 & 25 & 9 & \multirow{2}{*}{ (i) } \\
\hline & Marcq Baroeul M $\uparrow$ & 3 & 25 & 25 & 20 & 20 & 15 & \\
\hline \multirow{2}{*}{ 27.04. $15: 00$} & Nantes M & 3 & 25 & 25 & 25 & & & \multirow{2}{*}{ (i) } \\
\hline & Beziers $M$ & $\mathbf{0}$ & 20 & 20 & 18 & & & \\
\hline \multirow{2}{*}{ 27.04. $15: 00$} & RC Cannes M & 3 & 25 & 25 & 25 & & & \multirow{2}{*}{ (i) } \\
\hline & Saint-Raphael M & $\mathbf{0}$ & 22 & 23 & 23 & & & \\
\hline \multirow{2}{*}{ 24.04. $15: 30$} & Beziers M & 3 & 18 & 25 & 30 & 25 & & \\
\hline & Nantes $M$ & 1 & 25 & 23 & 28 & 16 & & \\
\hline \multirow{2}{*}{ 24.04. $15: 00$} & Marcq Baroeul M & 3 & 25 & 25 & 25 & & & \\
\hline & Mulhouse M & $\mathbf{0}$ & 17 & 20 & 23 & & & \\
\hline \multirow{2}{*}{ 24.04. 15:00 } & Saint-Raphael M & 3 & 25 & 25 & 25 & & & \\
\hline & RC Cannes M & $\mathbf{0}$ & 16 & 22 & 16 & & & \\
\hline \multirow{2}{*}{ 24.04. $15: 00$} & Venelles $\mathrm{M}$ & 1 & 25 & 22 & 21 & 22 & & \\
\hline & Le Cannet M & 3 & 11 & 25 & 25 & 25 & & \\
\hline
\end{tabular}

- Semi-final: Nessa fase eliminatória, composta por 6 partidas, prevíamos que as equipes vencedoras, de cada partida, seriam as mandantes. 
Em vista das partidas que foram analisadas anteriormente, vimos que a $1^{\underline{a}}$, 4 $4^{\underline{a}}$ e $5^{\underline{a}}$ não saíram como previsto. É importante lembrar que em fases eliminatórias, como essa, o número de fatores técnicos influencia ainda mais na atuação da equipe, mesmo não que sejam levados em consideração nesse trabalho. Mas, nas demais partidas a modelagem funcionou precisamente, em detalhes observe as duas tabelas abaixo:

Tabela 21: Médias para previsão da probabilidade de sets entre as respectivas equipes de cada partida.

\begin{tabular}{|c|c|c|c|c|}
\multicolumn{4}{c}{ MANDANTE } & \multicolumn{3}{c}{ PLACAR } & VISITANTE \\
\hline Le Cannet M & 0,61 & $\mathbf{3 X 0}$ & 1,07 & RC Cannes M \\
\hline Marcq Baroeul M & 0,78 & $\mathbf{2 X 3}$ & 1,42 & Nantes M \\
\hline Nantes M & 1,52 & $\mathbf{3 X 0}$ & 0,52 & Marcq Baroeul M \\
\hline RC Cannes M & 0,73 & $\mathbf{3 X 1}$ & 0,82 & Le Cannet M \\
\hline RC Cannes M & 0,73 & $\mathbf{3 X 0}$ & 0,82 & Le Cannet M \\
\hline
\end{tabular}

Tabela 22: Dados apresentados no espaço de pesquisa.

\begin{tabular}{|c|c|c|c|c|c|c|c|}
\hline Semi-finais & & & & & & & \\
\hline \multirow{2}{*}{ 05.05. 12:00 } & RC Cannes M $⿴$ & 3 & 25 & 25 & 25 & & \multirow{2}{*}{ (i) } \\
\hline & Le Cannet M & 0 & 21 & 16 & 23 & & \\
\hline \multirow{2}{*}{ 04.05. 15:00 } & Nantes M $\uparrow$ & 3 & 25 & 25 & 25 & & \multirow{2}{*}{ (i) } \\
\hline & Marcq Baroeul M & 0 & 18 & 14 & 22 & & \\
\hline \multirow{2}{*}{ 04.05. 15:00 } & RC Cannes M & 3 & 18 & 25 & 25 & 25 & \multirow{2}{*}{ (i) } \\
\hline & Le Cannet M & 1 & 25 & 23 & 23 & 20 & \\
\hline \multirow{2}{*}{ 01.05. 15:00 } & Le Cannet M & 3 & 25 & 25 & 25 & & \\
\hline & RC Cannes M & 0 & 21 & 20 & 12 & & \\
\hline \multirow{2}{*}{ 01.05. 15:00 } & Marcq Baroeul M & 2 & 25 & 22 & 25 & 13 & 10 \\
\hline & Nantes M & 3 & 14 & 25 & 21 & 25 & 15 \\
\hline
\end{tabular}

- $\quad$ Final: Nessa fase última eliminatória, composta por 2 partidas, prevíamos ambas as vitórias para RC Cannes M, ou seja, seria a campeã da categoria feminina.

Perante todas as informações analisadas a respeito dessa última fase, concluímos que a modelagem funcionou satisfatoriamente, e conseguiu prever corretamente a campeã do campeonato, da categoria feminina. É possível verificar essas informações com detalhes nas duas tabelas a seguir:

Tabela 23: Médias para previsão da probabilidade de sets entre as respectivas equipes de cada partida.

\begin{tabular}{|c|c|c|c|c|} 
MANDANTE & \multicolumn{3}{c}{ PLACAR } & VISITANTE \\
\hline Nantes M & 0,67 & $\mathbf{1 X 3}$ & 1,01 & RC Cannes M \\
\hline RC Cannes M & 1,31 & $\mathbf{3 X 1}$ & 0,68 & Nantes M \\
\hline
\end{tabular}

Tabela 24: Dados apresentados no espaço de pesquisa.

\begin{tabular}{|llllllll|}
\hline Final & & & & & & & \\
\hline \multirow{2}{*}{ 11.05. 15:00 } & RC Cannes M 10 & $\mathbf{3}$ & 25 & 20 & 25 & 25 & (i) \\
& Nantes M & $\mathbf{1}$ & 21 & 25 & 13 & 23 & \\
\hline \multirow{2}{*}{ 08.05. 15:00 } & Nantes M & $\mathbf{1}$ & 25 & 16 & 18 & 23 & \\
& RC Cannes M & $\mathbf{3}$ & 20 & 25 & 25 & 25 \\
\hline
\end{tabular}




\section{CONSIDERAÇÕES FINAIS}

Diante da falta de trabalhos que relacionem previsões em jogos de vôlei, que pudessem ser utilizados por estudantes nas escolas para prevê as partidas dos jogos escolares, aplicamos um método de previsão usando apenas média, divisão e porcentagem aplicado a um Campeonato Francês de Vôlei.

Segundo o que mostrou os resultados finais do modelo pela distribuição de Poisson, quando utilizado nas rodadas o funcionalmente acontece precisamente, com poucas margens de erro; já nas fases eliminatórias, isso muda um pouco, podem-se ocorrer algumas surpresas, como por exemplo, a equipe RC Cannes M chegar à final mesmo sua média de ataque sendo um pouco inferior a média de defesa da Le Cannet $M$, cujo desempenho da segunda é sutilmente melhor, mas nessa situação, também vale lembrar que o nível das equipes era muito próximo, e que a atuação de cada equipe muda durante a disputa em fases decisivas, a partir de outros fatores.

Além disso, pode-se concluir que a distribuição de Poisson não leva em conta os fatores ambientais, que inúmeras vezes atrapalham o desempenho das equipes, sejam por adaptação a outro estado, a inexistente familiaridade as quadras da região, e até mesmo pelo clima; assim como, os fatores físicos tem efeito direto sobre os jogadores, como no caso de lesões, algumas em que até requer substituição de um jogador, com efeito, podendo alterar o desempenho da equipe, positiva ou negativamente; mais os fatores técnicos, como mudança na escalação de jogadores e alteração de estratégia da equipe, principal responsável pela maioria das "surpresas".

Como sugestão de trabalhos, é possível desenvolver modelos de previsão a partir da distribuição de Poisson para os jogos interclasses escolares, jogos escolares da juventude, jogos do Campeonato Brasileiro de voleibol, Campeonato Sul-Americano e a Copa dos campeões do vôlei, da mesma maneira se pode utilizar em outros esportes, como Futebol, Basquete e Handebol.

\section{REFERÊNCIAS}

[1] Amaral, L. S.; Alves, D. A. N. S.; Modelagem estatística para previsão de resultados de jogo de futebol: Uma aplicação à copa do mundo da FIFA 2018.

[2] Borges, Márcia RO; Kieckow, Flávio. Interdisciplinaridade: Construindo Conceitos Matemáticos Através de Atividades Físicas.

[3] Lobato, Izabel Cristina; Almeida, Camila Marta. Intervenção Interdisciplinar Entre Educação Física E Matemática: A Partir das Oficinas do Jogo. XI Congresso Nacional de Educação, Educere, 2013. 


\section{Capítulo 20}

Reflexões sobre a formação matemática do Pedagogo

\section{Nayara do Nascimento Pereira \\ Nayara Lima Dutra Cavalcante \\ Milene de Fátima Soares}

Resumo: 0 presente artigo visa avaliar se os cursos de Pedagogia brasileiros dedicam parte significativa da carga horária para a formação matemática do pedagogo, com vistas a apresentar um breve panorama acerca das disciplinas relacionadas ao ensino da Matemática nos cursos de pedagogia das regiões brasileiras. 0 aporte teórico buscou embasamento principal em D’Ambrósio (1993) e (2011), Fiorentini (1994), Muniz (2014), Nacarato (2010) e Imbernón (2009). Para alcançar os objetivos propostos, utilizamos a pesquisa documental, empregando como técnicas de coleta de dados a análise documental, privilegiando a pesquisa quantitativa exploratória. Fundamentado na pesquisa realizada, pode-se constatar que os cursos de Pedagogia no Brasil dedicam uma pequena parte da carga horária total ao ensino da matemática, com necessidade de alguns ajustes para que obtenha êxito na formação integral do profissional.

Palavras-chave: Avaliação; Ensino da Matemática; Pedagogia; Formação de professores. 


\section{INTRODUÇÃO}

A Matemática é uma das ciências mais importantes do mundo, está presente em diversos contextos, mesmo que não seja tão perceptível, devendo ser abordada nas escolas desde a Educação Infantil. Dessa maneira, é necessário que o pedagogo seja um orientador no ato de despertar um novo olhar do aluno em relação à Matemática, de modo a oferecer uma visão instigante, desafiadora e prazerosa da disciplina. Desse modo, assumir a responsabilidade da formação matemática inicial dos estudantes é um grande desafio e requer de cada instituição de ensino superior dedicação de carga horária às disciplinas relacionadas a essa área do conhecimento, além de ser primordial, por parte dos professores, comprometimento, criatividade, domínio do conteúdo e formação adequados.

A relevância acadêmica demonstra-se, inicialmente, por meio dos resultados das avaliações do ensino básico brasileiros, como o Programa Internacional de Avaliação de Estudantes - Pisa, da Organização para a Cooperação e Desenvolvimento Econômico - OCDE, alertando acerca do desempenho insatisfatório dos jovens brasileiros no que tange aos conhecimentos relacionados à matemática, cuja performance média (377) ficou abaixo dos estudantes dos países membros da OCDE (490) em 2015 (BRASIL, 2016). Nesse aspecto, uma das ações possíveis para solucionar o problema está na oferta e melhoria da carga horária destinada ao estudo das disciplinas matemáticas.

Somado ao baixo desempenho matemático supracitado, a escolha do tema por parte das pesquisadoras ocorreu após constatar por meio do trabalho de conclusão de curso de Pedagogia do Centro Universitário Instituto de Educação Superior de Brasília - IESB, que apesar de se destacar frente às outras instituições de ensino superior do Distrito Federal no quesito carga horária disponibilizada para o ensino da matemática e auxiliar os futuros docentes no processo de ressignificação da disciplina, que inicialmente era negativo, ainda necessita de uma reavaliação e readequações na matriz curricular e ementas das disciplinas, com vistas a obter êxito em formar professores/pedagogos/educadores matemáticos (IESB, 2018).

Além disso, ao lermos a pesquisa de Pimenta et al. (2017), que destacou a indefinição do campo pedagógico, dispersão do objeto da pedagogia e da atuação profissional docente, não colaborando assim, para a formação do pedagogo que atuará no início da Educação Básica, sugerindo dentre várias possibilidades a de estudar e as matrizes dos cursos de Pedagogia, nos motivou ainda mais a seguir nesse caminho.

Desde já, é necessário repensar a formação de futuros professores com a Matemática, de modo que as Instituições de Ensino Superior dediquem em suas matrizes curriculares, uma oferta maior de disciplinas relacionadas ao ensino da Matemática na Educação Infantil e Anos Iniciais, a fim de despertar o prazer e segurança necessários à prática em sala de aula.

\section{METODOLOGIA}

A pesquisa é parte substancial a concretude de todo e qualquer projeto, onde os dados levantados poderão ser capazes de responder ou não problemas propostos, bem como refutar os objetivos inicialmente elencados. Segundo Gil (2007, p. 17), a pesquisa é definida como:

[...] procedimento racional e sistemático que tem como objetivo proporcionar respostas aos problemas que são propostos. A pesquisa desenvolve-se por um processo constituído de várias fases, desde a formulação do problema até a apresentação e discussão dos resultados.

No âmbito do estudo, com vistas a avaliar a formação matemática do pedagogo a nível nacional, foi realizada a análise das cargas horárias nas grades curriculares dos cursos de Pedagogia ofertados no Brasil, disponíveis na plataforma do Ministério da Educação, sistema e-MEC, optando-se por uma instituição pública e uma privada que obtiveram nota 4 e 5 no Exame Nacional de Desempenho de Estudantes - Enade e que ofertassem a maior carga horária total de curso, de modo a restringir o espaço amostral de análise.

A partir da filtragem, verificou-se que a utilização da abordagem quantitativa estaria mais próxima da realidade inicial de pesquisa diante da abrangência dos 2.400 cursos de Pedagogia ativos no Brasil (2019, e-MEC).

A pesquisa é de cunho exploratório dado que visa "proporcionar maior familiaridade com a questão do problema, com vistas a torná-lo mais explícito ou a construir hipóteses" (GIL, 2007, p. 41). 
Apresentados os percursos metodológicos, é importante destacar que os instrumentos de pesquisa utilizados foram: o levantamento e análise das cargas horárias da Matriz Curricular, do curso de Pedagogia disponíveis site das instituições selecionadas.

\section{UM POUCO DA HISTÓRIA DAS TENDÊNCIAS DE ENSINO DA MATEMÁTICA NO BRASIL}

Muitos educadores referem-se ao Movimento da Matemática Moderna - MMM como o marco para as primeiras mudanças ocorridas no ensino da matemática no Brasil. Mas, antes desse grande movimento acontecer no país, a Matemática sofreu algumas alterações, incluindo a "criação" da disciplina Matemática. Antes, o estudo era realizado separadamente, por meio da aritmética, álgebra e geometria; que incluía a trigonometria (DASSIE e ROCHA, 2016).

Para melhor compreender as modificações no processo de ensino da Matemática no Brasil, apresentaremos seis tendências: Formalista Clássica; Empírico-ativista; Formalista Moderna; Tecnicista e suas variações; Construtivista e Sócioetnoculturalista, que conforme Fiorentini (1995, p. 5) "foram aquelas tendências, que [..] tiveram uma presença marcante na configuração do ideário da Educação Matemática brasileira".

A Tendência Formalista Clássica trazia o ensino da matemática centrado no professor. Nessa tendência, a Matemática era vista como um conhecimento preexistente que não pode ser criado ou inventado, por isso o aluno não tinha importância e a possibilidade de se melhorar o ensino da matemática estava restrita a um melhor estudo do conteúdo pelo professor e pelos formuladores dos currículos (FIORENTINI, 1995).

A Tendência Empírico-ativista surgiu no Brasil na década de 1920 e veio em oposição ao ensino clássico, que não valorizava o aluno. Trouxe um ensino centrado no "aprender fazendo" e o professor passava a ser um facilitador do processo de ensino e aprendizagem. Fiorentini (1995) destacou que a pesquisa nessa tendência seguia duas vertentes - uma de investigar como a criança pensa e a outra, a de desenvolver atividades lúdicas que possibilitariam a descoberta da matemática e desenvolveriam a criatividade.

A partir da década de 50 ocorreram, no Brasil, cinco Congressos Brasileiros de Ensino de Matemática $(1955,1957,1959,1962$ e 1966) que permitiram uma reflexão sobre os anseios dos educadores quanto às mudanças no ensino da Matemática. Reflexões que foram possíveis após o empenho de muitos professores e matemáticos que aderiram ao movimento internacional conhecido como Movimento da Matemática Moderna (MMM). Conforme Valente (2008, p. 584): “O Movimento da Matemática Moderna é a expressão utilizada no âmbito dos estudos sobre o ensino da matemática que caracterizava um período em que se elaboram novas referências para o ensino da disciplina".

Assim, o MMM teve como finalidade adequar o currículo escolar ao progresso científico-tecnológico, visando a formação de um especialista matemático.

Já a Tendência Tecnicista e suas variações surgiram após o golpe militar de 1964 e tinha um caráter funcional, ou seja, a escola deveria ser aperfeiçoada para manter o sistema rumo ao progresso (FIORENTINI, 1995).

A Tendência Construtivista ganhou força no Brasil nos anos 60 e 70. 0 seu principal propagador foi o educador matemático húngaro-canadense Zoltan Pál Dienes, doutor em matemática pela Universidade de Londres e criador do material concreto - blocos lógicos - com o propósito de contribuir com o desenvolvimento das primeiras noções lógicas da criança.

Essa tendência foi marcante e influenciou o ensino da Matemática de forma que práticas pedagógicas mecanizadas e associacionistas fossem ressignificadas por uma prática que considerava a construção das estruturas lógico-matemáticas por meio do uso de materiais concretos, uma verdadeira revolução no modo de apreender conhecimento.

A Tendência Sócioetnocultural, contribuiu para buscar razões que explicassem o fracasso dos alunos, tirando o foco somente da criança. Um grande representante dessa tendência é Ubiratan D’Ambrósio, que define a Etnomatemática como "a arte ou técnica de explicar, de conhecer, de entender nos diversos contextos culturais” (D’AMBROSIO, 1993, p. 5).

\section{A FORMAÇÃO DE PEDAGOGOS PARA ENSINAR}

Percebe-se que ao longo dos anos, os modos e maneiras de ver, ensinar e aprender matemática sofreram mudanças significativas, considerando inclusive, estudos, pesquisas e reflexões acerca do ensino da 
Matemática. Logo, tão importante quanto compreender como a criança constrói o conhecimento matemático é a formação do profissional que orientará esse processo junto aos estudantes.

Nessa perspectiva de formação docente, Imbernón (2009) trouxe três formações essenciais para que ocorra na prática pedagógica mudanças eficazes: a formação inicial, a formação permanente e a formação continuada.

Partindo dessas três linhas de formação, Imbernón (2009) fez uma crítica a formação inicial de professores, na qual impõe-se um modelo ideal de professor e as instituições que formam esses profissionais, simplesmente reproduzem esse modelo ao longo dos anos em seus cursos.

Há a necessidade dos cursos de licenciatura se reinventarem, para que consigam em sua plenitude disponibilizar ao mercado de trabalho profissionais capazes de refletir sobre suas práticas pedagógicas por meio de autoavaliação constante, de modo que norteiem o seu trabalho qualitativamente.

Ter a capacidade de agir e refletir, dentro da sua própria prática pedagógica de maneira a permitir modificações dessas práticas é o que Imbernón (2009) apresentou com fundamental para desenvolver o professor na formação permanente. E é durante esse processo, por meio da prática profissional, mais precisamente em seus cinco primeiros anos, que o professor se constitui, cada um com suas qualidades, especificidades e até defeitos.

Assim, ao ingressar na formação inicial e vivenciar a formação permanente o professor deve criar o hábito de atualizar-se, tendo em vista as mudanças do campo educacional e busque ao longo de sua carreira formação continuada, que existe para contribuir nas ações e reflexões da prática docente.

No que se refere a professores que cursam licenciatura em Pedagogia, mas especificamente as disciplinas relacionadas ao ensino da Matemática, a realidade na formação é mais complexa, em razão desses profissionais, precisarem ensinar Matemática e as suas experiências negativas, marcadas ao longo do processo da educação básica, gerarem receio no processo de ensino-aprendizagem ao longo do curso.

Assim as instituições têm:

O desafio de romper com as crenças e culturas de aulas de matemática construídas ao longo de suas trajetórias estudantis. Essa constatação exige que sejam adotadas práticas de formação nas quais essas crenças e esses modelos de aula sejam explicitados, discutidos e problematizados durante a graduação (NACARATO, 2010, p. 906)

Deste modo, um grande desafio na formação de professores pedagogos, nas disciplinas relacionadas à Matemática é propor ações que permitam aos graduandos superar esses obstáculos que os impedem de avançar no processo de aprendizagem e domínio do conteúdo a ser lecionado. Deixando no passado, sentimentos negativos e abraçando sentimentos positivos ao perceberem que a Matemática é para todos e que, enquanto profissionais podem fazer a diferença no ensino matemático.

Mais do que modificar sentimentos e percepções acerca da Matemática, a formação em Pedagogia não deve contemplar o profissional apenas como professor ou pedagogo, mas também como educador matemático. Muniz (2014, p. 13) ressaltou que "ser educador matemático é fazer despertar em cada criança e jovem, sob nossa responsabilidade educativa, o ser matemático que existe potencialmente em cada um".

Ainda segundo Muniz (2014, p. 01):

A formação do educador matemático deve garantir a aquisição de algumas competências consideradas como essenciais para a atuação junto à crianças, jovens e adultos, promovendo a aprendizagem da matemática. É necessário observar que essas competências não são construídas em curto período de tempo, e tampouco, se limita ao período de formação inicial do professor. A aquisição dessas competências pode iniciar já no nosso período de vida escolar, enquanto aluno. Aprendendo matemática enquanto alunos da escola fundamental e média, adquirimos conhecimentos matemáticos importantes, e mais, desenvolvemos conceitos acerca sobre o como aprendemos a matemática, qual o seu significado para nossa vida, quais os espaços culturais e ainda sob quais formas a matemática se apresenta, quais são nossas limitações e potencialidades em lidar com a matemática. 
Deste modo, percebemos claramente a necessidade de uma melhor formação do pedagogo que atuará desde a Educação Infantil. Este sai da graduação, muitas vezes, sem as condições mínimas para lecionar Matemática acabando por criar, em seus estudantes experiências e sentimentos negativos relacionados a essa área do conhecimento.

Posteriormente, esses alunos chegam ao ensino superior com dificuldades não sanadas, que não são rompidas, alimentando esse ciclo de formação inadequado, que só terá fim se o professor/pedagogo vivenciar e aprender na formação inicial os requisitos mínimos para tornar-se um educador matemático e avançar com a formação continuada.

\section{OS CURSOS DE PEDAGOGIA NO BRASIL: CARGA HORÁRIA DEDICADA AO ENSINO-APRENDIZAGEM DA MATEMÁTICA}

Na perspectiva de formar pedagogos capazes de assumir o papel de educadores matemáticos, pautadas nas considerações do artigo de conclusão de curso que demonstraram que, o IESB prepara satisfatoriamente o profissional para lecionar matemática em sala de aula disponibilizando 5,4\% de todo o curso de pedagogia às disciplinas matemáticas, mas que ainda necessitam de alguns ajustes para que obtenha excelência na formação desse profissional. Percebemos por meio dos dados obtidos na pesquisa que as matrizes curriculares analisadas também dedicam um pequeno tempo do curso às disciplinas relacionadas à matemática e que, visando preparar o professor para orientar a formação matemática de seus alunos pode ou não ser satisfatória.

Sendo assim, é fundamental que as instituições usem de diversas ferramentas de avaliação ao longo da graduação, para identificar e corrigir lacunas ao longo do processo formativo, que possam contribuir na formação integral do pedagogo como educador matemático.

Nessa ótica, Sant'Anna traz a avaliação como:

Um processo pelo qual se procura identificar, aferir, investigar e analisar as modificações do comportamento e rendimento do aluno, do educador, do sistema, confirmando se a construção do conhecimento se processou, seja este teórico (mental) ou prático. (SANT'ANNA,1998, p.29,30)

Assim, para esclarecer melhor a pesquisa realizada, selecionamos as duas instituições de cada região brasileira que ofertam a maior carga horária matemática nos cursos de Pedagogia:

\begin{tabular}{|c|c|c|c|c|c|}
\hline \multicolumn{2}{|c|}{ Estado } & Instituição & $\begin{array}{l}\text { Carga } \\
\text { Horária } \\
\text { total }\end{array}$ & $\begin{array}{l}\text { Carga Horária } \\
\text { matemática }\end{array}$ & $\begin{array}{l}\text { Percentual em } \\
\text { relação a carga } \\
\text { horária total }\end{array}$ \\
\hline \multirow{3}{*}{$\begin{array}{l}\text { Região } \\
\text { Norte }\end{array}$} & Amazonas & $\begin{array}{l}\text { Universidade do Estado do } \\
\text { Amazonas }\end{array}$ & 3355 & 180 & $5,4 \%$ \\
\hline & \multirow{2}{*}{ Acre } & \multirow{2}{*}{ Centro Universitário SENAC } & 3200 & 144 & $4,5 \%$ \\
\hline & & & 6555 & 324 & $4,9 \%$ \\
\hline \multirow{3}{*}{$\begin{array}{l}\text { Região } \\
\text { Nordeste }\end{array}$} & Ceará & Universidade Federal do Ceará & 3200 & 352 & $11,0 \%$ \\
\hline & \multirow{2}{*}{$\begin{array}{l}\text { Rio Grande do } \\
\text { Norte }\end{array}$} & \multirow{2}{*}{ Centro Universitário FACEX } & 3200 & 180 & $5,6 \%$ \\
\hline & & & 6400 & 532 & $8,3 \%$ \\
\hline \multirow{3}{*}{$\begin{array}{l}\text { Região } \\
\text { Centro- } \\
\text { Oeste }\end{array}$} & Distrito Federal & $\begin{array}{l}\text { Centro Universitário do Instituto } \\
\text { de Educação Superior de Brasília - } \\
\text { IESB }\end{array}$ & 3360 & 180 & $5,4 \%$ \\
\hline & \multirow{2}{*}{$\begin{array}{l}\text { Mato Grosso do } \\
\text { Sul }\end{array}$} & \multirow{2}{*}{\begin{tabular}{|c|} 
Universidade Estadual de Mato \\
Grosso do Sul \\
\end{tabular}} & 3322 & 204 & $6,1 \%$ \\
\hline & & & 6682 & 384 & $5,7 \%$ \\
\hline \multirow{3}{*}{$\begin{array}{l}\text { Região } \\
\text { Sudeste }\end{array}$} & Espírito Santo & $\begin{array}{l}\text { Faculdade Capixaba de Nova } \\
\text { Venécia }\end{array}$ & 3200 & 180 & $5,6 \%$ \\
\hline & \multirow{2}{*}{ São Paulo } & \multirow{2}{*}{$\begin{array}{l}\text { Universidade Federal de São } \\
\text { Paulo }\end{array}$} & 3730 & 300 & $8,0 \%$ \\
\hline & & & 6930 & 480 & $6,9 \%$ \\
\hline \multirow{3}{*}{ Região Sul } & Paraná & Universidade Federal do Paraná & 3200 & 120 & $3,8 \%$ \\
\hline & \multirow{2}{*}{ Santa Catarina } & \multirow{2}{*}{$\begin{array}{c}\text { Universidade do Oeste de Santa } \\
\text { Catarina }\end{array}$} & 3200 & 120 & $3,8 \%$ \\
\hline & & & 6400 & 240 & $3,8 \%$ \\
\hline
\end{tabular}

A partir dos dados obtidos, foi possível constatar que duas instituições da Região Nordeste se destacam no que se refere à carga horária dedicada ao estudo das disciplinas matemáticas, com notoriedade à 
Universidade Federal do Ceará que oferta 11\% do total da sua carga horária ao ensino da disciplina. Em contrapartida as instituições da Região Sul, que possuem a carga horária total do curso equivalente a da Região Nordeste dedicam apenas 3,8\% dessas horas para o estudo e prática das disciplinas matemáticas.

Considerando que o licenciado em Pedagogia é o responsável por conduzir a formação matemática basilar dos alunos, é de suma importância que as instituições de ensino tenham um olhar diferenciado sobre a distribuição dessa carga horária para que ao longo do processo de formação inicial desse profissional, consigam refletir, reorganizar, planejar e atingir objetivos que abranjam um pedagogo capaz de refletir moldar-se ao longo sua formação e buscar aperfeiçoamento que contemple em sua prática pedagógica a formação integral de cada estudante.

A análise do panorama nacional acerca da dedicação à oferta de disciplinas relacionadas à Matemática nos cursos de Pedagogia é fundamental para despertar uma verdadeira reflexão da comunidade acadêmica acerca do tema, de modo a despertar interesse em aprofundar a pesquisa e posteriormente pensar em possíveis melhorias na formação assim como, melhor compreender a ementa proposta nessas disciplinas e a metodologia, pois como destaca Muniz (2014, p.13), "ser educador matemático é fazer despertar em cada criança e jovem, sob nossa responsabilidade educativa, o ser matemático que existe potencialmente em cada um".

\section{CONSIDERAÇÕES FINAIS}

É indispensável reconhecer que o artigo permite reflexões acerca da quantidade de horas dedicadas às disciplinas matemáticas nos cursos de Pedagogia e se realmente são suficientes para formar o docente educador matemático.

Ao analisar o contexto se faz necessário que as instituições avaliem se este tempo dedicado às disciplinas matemáticas é o necessário para propor ações que permitam ao graduando superar obstáculos durante a sua formação tendo assim, condições de orientar o processo de ensino- aprendizagem, relacionado à Matemática.

Entretanto, é notório que somente a carga horária não é suficiente para estabelecer se a formação de pedagogos que ensinam matemática é adequada, mas para que ocorram mudanças acerca da formação de professores, analisar a distribuição das horas é apenas o primeiro passo para propor reflexões, novos olhares e meios de avaliação sobre a construção do professor educador matemático.

Contudo, o tema abordado é instigante e desafiador, pois abre a possibilidade de aprofundamentos na avaliação dos cursos de Pedagogia oferecidos em território nacional, não somente no âmbito da matemática, abrindo margem para a busca de melhoria na formação global ofertada aos graduandos de Pedagogia por meio da avaliação, reavaliação e auto avaliação constante do curso ofertado.

\section{REFERÊNCIAS}

[1] Bissoli da Silva, C. S. Curso de Pedagogia no Brasil: História e Identidade. 3. ed. Campinas: Autores Associados, 2006.

[2] Brasil. Base Nacional Comum Curricular (BNCC). Brasília, 2017. Disponível em: <http://basenacionalcomum.mec.gov.br/wp-content/uploads/2018/02/bncc-20dez-site.pdf>. Acesso em: 19 abril. 2018.

[3] Brasil. Conselho Nacional Educação. Resolução CNE/CP n. 1, de 15 de maio de 2006.

[4] Brasil. Lei no 9.394, de 20 de dezembro de 1996. Estabelece as diretrizes e bases da educação nacional. Brasília: Senado Federal, 1996.

[5] Brasil. Ministério da Educação. Média em matemática está entre as menores do Pisa. Disponível em: <http://portal.mec.gov.br/ultimas-noticias/222-537011943/42771-media-em-matematica-esta-entre-as-menoresdo-pisa>. Acesso em: 12 mai. 2018.

[6] Brzezinski, I. Pedagogia, Pedagogos e Formação de Professores: 7ạ ed. (Busca e movimento). Campinas: Papirus, 1996.

[7] Cavalcante, Nayara, Pereira, Nayara. A formação matemática do pedagogo concluinte do Centro Universitário Instituto de Educação Superior de Brasília - Iesb. Disponível em: <http://biblioteca.iesb.br/>. Acesso em:28 de jun. 2019.

[8] D’ambrosio, Ubiratan. Educação matemática da teoria à prática. 22ª ed. São Paulo: Editora Papirus, 2011. 
[9] D’ambrosio, Ubiratan. Etnomatemática: Arte ou técnica de explicar e conhecer. 2a ed. São Paulo: Editora Ática, 1993.

[10] Dassie, Bruno Alves; Rocha, José Lourenço da. O ensino da matemática no Brasil nas primeiras décadas do século XX. 2016.2018 Disponível <http://www.dalicenca.uff.br/images/stories/caderno/volume4/da_Licena_Bruno.pdf>. Acesso em:15 abr. 2018.

[11] E-Mec. Cadastro Nacional de Cursos e Instituições de Educação Superior Cadastro e-MEC. Disponível em <http:// http://emec.mec.gov.br/>. Acesso 18 de jun. 2019.

[12] Fiorentini, D. Alguns modos de ver e conceber o ensino da matemática no Brasil. 1995. Revista Ztetikê Campinas: $\quad$ FE-Unicamp. Tese de Doutorado. Disponível <https://periodicos.sbu.unicamp.br/ojs/index.php/zetetike/article/view/8646877/15035>. Acesso em: 10 mai. 2018.

[13] Gil, Antônio Carlos. Como elaborar projetos de pesquisa. São Paulo: Atlas, 2007.

[14] Gil, Antonio Carlos. Métodos e técnicas de pesquisa social. 6. ed. São Paulo: Atlas, 1999.

[15] Iesb - Instituto de Educação Superior de Brasília. Documento Institucional: Projeto Pedagógico do Curso de Pedagogia. 2016.

[16] Imbernón, Francisco. Formação docente e profissional. 7. ed. São Paulo: Cortez, 2009.

[17] Inep. Brasil no Pisa2015-Sumário Executivo, Daeb, Inep. 2016. Disponível em: <http://download.inep.gov.br/acoes_internacionais/pisa/documentos/2016/pia_brasil_2015_sumario_executivo.pdf $>$. Acesso 20 de mai. 2018.

[18] Libâneo, J. C. Que destino os educadores darão a Pedagogia. In: Pimenta, S. G. (Coord.). Pedagogia, Ciência da Educação? 2ª ed. São Paulo: Cortez, 1998.

[19] Muniz, C. A. Ser educador matemático, VI Encontro Brasiliense de Educação Matemática. Brasíla, 2014. Disponível em: <http://www.viebrem.sbemdf.com/wp-content/uploads/2014/09/Ser-Educador-Matem-ticoCristiano-Muniz.pdf>. Acesso em 13 mar. 2018.

[20] Nacarato, A. M. A formação matemática das professoras das séries iniciais: a escrita de si como práticas de formação. Revista Bolema, Rio Claro (SP), v. 23, n. 37, p. 905-930, dez. 2010. Disponível em: <http:/www.redalcy.org/articulo.oa?=291221915004>. Acesso em: 20 mar. 2018.

[21] Pimenta, Selma Garrido.; Fusari, José Cerchi.; Pedroso, Cristina Cinto Araújo;Pinto, Umberto de Andrade. Os cursos de licenciatura em pedagogia: fragilidades na formação inicial do professor polivalente. Educ. Pesqui., São Paulo, v. 43, n. 1, p.15-30, jan./mar. 2017. Disponível em: < http://dx.doi.org/10.1590/S1517-9702201701152815>. Acesso em: 26 jun. 2019.

[22] Sant'anna,Ilza Martins. Porque avaliar?:Como avaliar?; Critérios e instrumentos. 3aㅗ Edição, Petrópolis,RJ:Vozes, 2003.

[23] Valente, W. R. Osvaldo Sangiorgi e o Movimento da Matemática Moderna no Brasil. Revista Diálogo Educacional, Curitiba, v. 8, n. 25, p. 583-613, 2008. 


\section{Capítulo 21}

\section{Perfil do Professor de Matemática: Uma análise sob a percepção dos docentes da Educação Básica}

\section{Armando da Silva Pereira Neto}

Erivelton da Silva Paz.

Marilene Rosa dos Santos

Resumo: 0 presente estudo tem como objetivo principal estabelecer o perfil do professor de Matemática à luz das atribuições propostas por Pedro Demo, além de analisar as ideias de formação do professor, competências profissionais, saber e prática docente acerca de pensamentos de alguns estudiosos, como: Setzer, Perrenoud, Tardif e Pimenta. Através do proposto por Demo, tornou-se possível a comparação de suas atribuições aos dados coletados nas entrevistas com os professores. Os estudantes depositam apreensão e desinteresse em virtude da abstração dos objetos de estudo da Matemática, dessa forma surge a necessidade de entender qual o perfil dos professores de Matemática na atualidade e, através disso, motivar o surgimento de novas abordagens didáticas, em consonância com as ideias dos autores mencionados. A metodologia empregada deu-se através de um questionário composto por cinco questões subjetivas, usadas para entrevistar oito professores de Matemática da rede municipal de ensino das cidades de Correntes e Paranatama, ambas localizadas no agreste meridional pernambucano. A análise dos dados aponta para uma não totalidade de características emparelhadas à ideia proposta por Demo a respeito do perfil do professor do futuro, no entanto, assemelha-se principalmente no que diz respeito a trabalhar Matemática com interdisciplinaridade, haja vista que foi na pergunta que remete a esse perfil onde se registrou a maior concordância nas respostas apresentadas. Outrossim, estão presentes neste estudo aspectos sobre a formação dos professores nos cursos de licenciatura e as dificuldades encontradas durante o exercício da docência no que se refere à educação básica.

Palavras-chave: Perfil do professor de Matemática; professor do futuro; prática docente. 


\section{INTRODUÇÃO}

As metodologias de ensino tradicionais, constituída principalmente de aula expositiva, foi durante séculos a principal técnica de ensino e ainda está presente no atual contexto educacional. Quando são os únicos recursos metodológicos utilizados para lecionar, torna-se uma abordagem inadequada ao desenvolvimento do processo de ensino e aprendizagem, visto que o somente o professor é o sujeito ativo neste processo.

No ensino da Matemática, as aulas tradicionais tendem a não estabelecer uma relação entre a teoria dos conteúdos lecionados com as situações do cotidiano dos alunos, fator este que dificulta a significação, resultando em uma visão deturpada de que a Matemática é apenas seguir regras e aplicar algoritmos.

Nesta metodologia didática, geralmente, os alunos são submetidos a uma vasta e cansativa bateria de exercícios repetitivos, no qual são meras aplicações de um modelo de solução predeterminada pelo professor, o que não contribui para o desenvolvimento do pensamento crítico, apenas para a memorização dos algoritmos matemáticos, e assim, estereotipando a Matemática como uma disciplina abstrata e que não há muita relação com a vida em sociedade. Tais situações levam o aluno, ainda mais, à passividade na busca e construção do conhecimento.

Sabendo da necessidade de novas abordagens didáticas e pedagógicas nas instituições de ensino que promovam um ambiente suscetível para um processo de ensino e aprendizagem eficaz, o presente estudo foi desenvolvido a fim de investigar o perfil dos professores de Matemática em escolas da rede pública de ensino, quanto a suas abordagens metodológicas de ensino, além de características intrínsecas ao profissional de educação. Tais informações podem estabelecer uma perspectiva esperançosa de melhoria no cenário educacional, dependendo diretamente do perfil atual do professor de Matemática quanto ao exercício da profissão.

Destarte, o presente estudo objetiva estabelecer o perfil do professor de Matemática de duas escolas da rede pública de ensino, situadas no agreste meridional pernambucano. Especificamente, pretendendo realizar uma análise quantitativa e qualitativa dos diferentes perfis dos professores das escolas.

Para levar a cabo esse estudo, foi realizada uma pesquisa de campo objetivando coletar as informações necessárias através de um questionário/entrevista com oito professores da rede pública de ensino.

O questionário aplicado continha cinco questões. A primeira questão referia-se ao uso de instrumentos eletrônicos como recurso didático; o segundo questionamento, sobre a importância de trabalhar a Matemática com interdisciplinaridade; a terceira, indagava sobre a pesquisa na vida profissional do docente, principalmente na educação básica; outra interrogação, foi relativa aos elementos essenciais para formação do professor; e por fim, foi questionado sobre as dificuldades do professor da educação básica em formular projetos didáticos. Tais informações forneceram suporte para determinação do perfil dos docentes.

\section{METODOLOGIA}

Foi realizada uma entrevista, aplicando um questionário, com oito professores que lecionam Matemática de duas escolas da rede pública de ensino, situadas nas cidades de Correntes e Paranatama, no agreste meridional pernambucano.

Os docentes são responsáveis por ministrar aulas em turmas do 6o (sexto) ao 9o (nono) ano do ensino fundamental em suas respectivas escolas. Somente cinco professores têm formação na área em destaque, os demais são formados nos cursos de Licenciatura em Biologia, Pedagogia e Geografia, todavia executam o trabalho como professores de Matemática há algum tempo.

O questionário foi composto por cinco questões subjetivas que versam sobre aspectos importantes para a construção da identidade profissional. A entrevista tinha por intenção conhecer alguns aspectos de cada professor, tais como: utilização de instrumentação eletrônica, interdisciplinaridade, o professor enquanto pesquisador, aspectos essenciais para formação dos professores da educação básica e formulação de proposta própria. 0 conteúdo de cada pergunta do questionário está ilustrado na Figura 1. 
Figura 1 - Questionário aplicado aos docentes entrevistados para determinação do perfil do professor

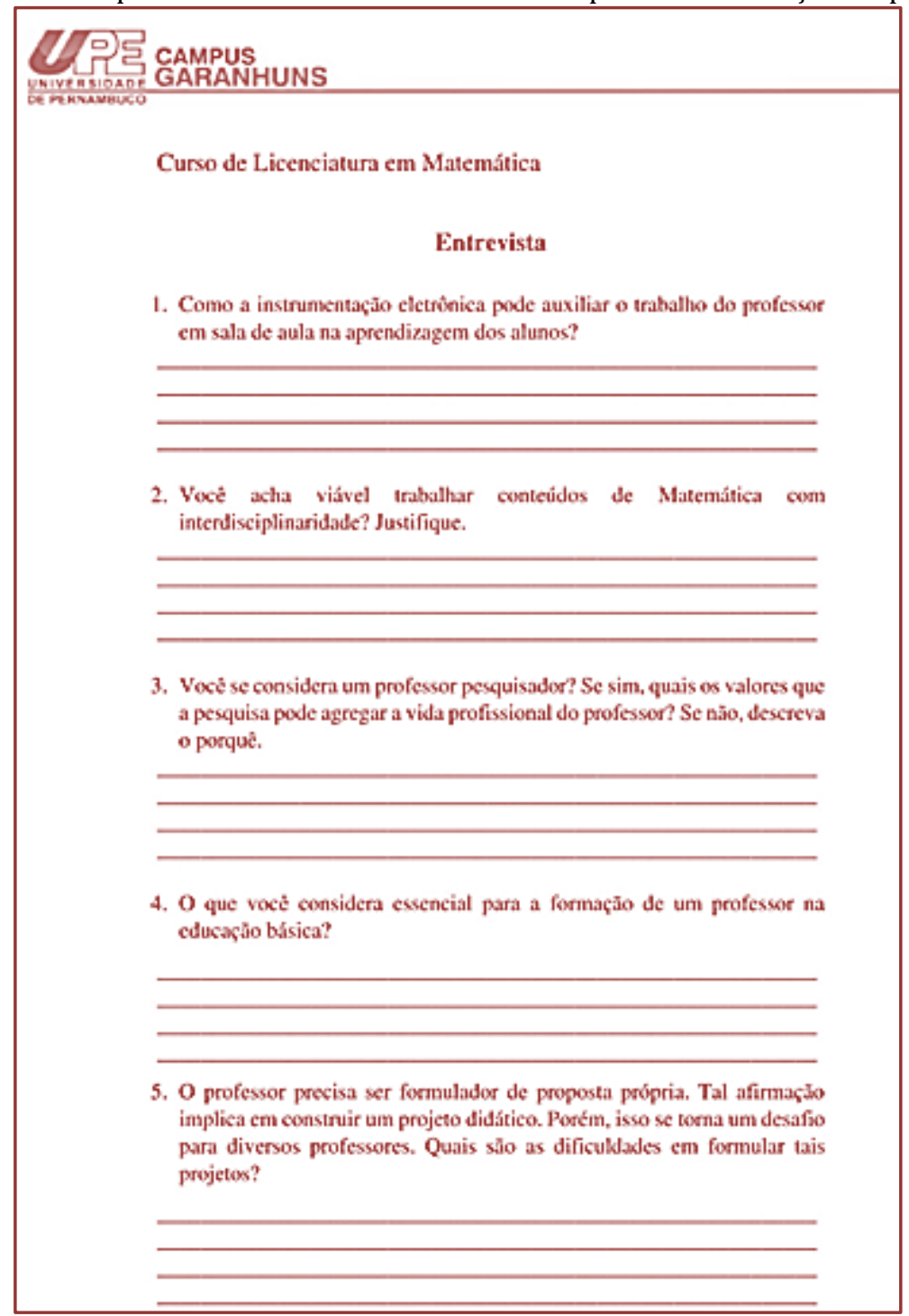

Fonte: autoria própria

Diante das condições estabelecidas, a presente pesquisa visa apresentar uma análise de caráter qualitativo e diagnóstico, com a intenção de investigar e elencar diversas características pertinentes para a elaboração do perfil do professor através de uma perspectiva das obras de autores como Demo, Perrenoud, Pimenta, Setzer e Tardif.

\section{DESENVOLVIMENTO}

Segundo Demo (2004), o professor do futuro deverá desfrutar da pesquisa de forma habitual como reconstrução do conhecimento, questionar as informações e não meramente reproduzí-las. "Não basta, pois, coletar conhecimento ou informação, trazer para a sala de aula revistas usadas, recortes de jornal, copiar da internet, porque isto é apenas material de trabalho. Pesquisa começa quando se questiona esse material, desconstrói-se e reconstrói-se" (DEMO, 2004, p. 78).

0 autor exprime a ideia de que muitos consideram o aprendizado apenas como o domínio de conteúdos tidos pelo professor e que é transmitido para os alunos por meio de macetes simplificados. Nisto, precisase compreender a pesquisa como um argumento facilitador e solucionador do raciocínio mencionado, pois se trata de algo enriquecedor na vida do educador e do educando. 
Além de pesquisador, Demo defende que o professor deverá ser formulador de proposta própria e elaborar tais propostas com autonomia, afirmando que:

A habilidade de elaboração própria no professor costuma condensar-se na ideia do "projeto pedagógico" próprio, desafio que ainda não conseguimos adequadamente resolver. No professor básico, o projeto pedagógico geralmente está ausente, porque não se aprendeu a pesquisar e elaborar. (...) Ainda não percebemos que para ser professor é mister ser em alguma medida pedagogo. "Cuidar da aprendizagem do aluno" não é atividade que se aprenda por osmose, ou por simples decorrência do título de $\mathrm{PhD}$, ou como encenação caricata em sala aula. Exige conhecimento de causa, traquejo em teoria da aprendizagem, reflexão madura sobre como avaliar e orientar (Demo, 2004, p. 82).

Segundo Setzer (2001) o professor do futuro deve adaptar-se às instrumentações eletrônicas por ser mais eficiente e atraente atualmente. Outro aspecto importante do professor é tornar-se interdisciplinar, visto a necessidade de integrar as disciplinas e tornar os conhecimentos mais próximos e relacionados entre si.

É válido salientar, segundo a proposta de Pedro Demo, a importância da incessante busca do conhecimento por parte do professor, haja vista que o aluno aprende mais e melhor se o seu educador bem aprender. Trata-se, portanto, da atualização permanente que visa à inovação da sua metodologia de ensino mediante os processos evolutivos na sociedade que, a cada dia, surpreende com novas oportunidades para melhorar as condições de ensino, dando ao professor a possibilidade de reinventar-se.

No campo da competência profissional, Perrenoud (1999) enfatiza mais nas habilidades e técnicas. Para o autor, a competência profissional é um composto de aptidões cognitivas para solucionar diversas situações com êxito, apoiada nos conhecimentos necessários para tal. Nesse sentido, é importante que o profissional da educação tenha conhecimento pedagógico, didático e teórico a fim de promover um ambiente propenso à aprendizagem.

De acordo com Tardif et al. (1991), os múltiplos tipos de saberes (das disciplinas, curriculares, profissionais e da experiência) são partes que compõe a prática docente, e o que diferencia cada um dos saberes depende vínculo do professor com cada um deles. Para o autor, os professores mantêm uma "relação de exterioridade" com os saberes de formação profissional e das disciplinas curriculares, pois esses conhecimentos não pertencem ao sujeito e nem são definidos ou designado por ele, visto que recebelhes já determinados em sua forma e conteúdo. Inverso a isso, o autor define "relação de interioridade" os saberes da experiência do docente, no qual estabelece-se a apropriação dos saberes curriculares e profissionais.

Tardif (1999) explana relativo aos saberes profissionais e sua relação na problemática da profissionalização do ensino e da formação de professores, e destaca alguns pontos referentes ao conhecimento profissional, tais como: o conhecimento é adquirido na maioria das vezes na universidade, que prevê apenas uma titulação; é pragmático, visando a resolução de problemas; é destinado a um grupo que poderá fazer uso do conhecimento de forma competente; é de responsabilidade do próprio profissional a sua utilização; requer uma formação contínua etc.

Logo, em relação à pratica docente, pode-se afirmar que:

Nas práticas docentes estão contidos elementos extremamente importantes, tais como a problematização, a intencionalidade para encontrar soluções, a experimentação metodológica, o enfrentamento de situações de ensino complexas, as tentativas mais radicais, mais ricas e mais sugestivas de uma didática inovadora, que ainda não está configurada teoricamente (PIMENTA, 1996, p. 83).

\section{RESULTADOS E DISCUSSÃO}

Na primeira pergunta, foi indagado aos professores sobre a maneira que a instrumentação eletrônica pode auxiliar a prática docente em sala de aula para promover a aprendizagem dos alunos. As respostas de cada professor podem ser analisadas na Tabela 1. 
Tabela 1 - Respostas dos professores entrevistados referente à primeira pergunta

\begin{tabular}{|c|c|}
\hline Professor & Resposta \\
\hline P1 & $\begin{array}{l}\text { Facilita a apresentação dos conteúdos proporcionando um momento que } \\
\text { requer maior atenção o que facilita o processo de ensino-aprendizagem } \\
\text { especificamente dos conteúdos de geometria e trigonometria que tem } \\
\text { softwares específicos }\end{array}$ \\
\hline P2 & $\begin{array}{l}\text { Propiciando condições aos professores de conhecerem e utilizarem os } \\
\text { procedimentos digitais em diversos campos, bem como desenvolver } \\
\text { habilidades com os mesmos e manter-se atualizados. }\end{array}$ \\
\hline P3 & $\begin{array}{l}\text { A instrumentação eletrônica nos proporciona uma grande variedade de } \\
\text { maneiras para que possamos enriquecer nossas aulas, com isso melhorando a } \\
\text { aprendizagem dos alunos. }\end{array}$ \\
\hline P4 & $\begin{array}{l}\text { A parte eletrônica deve ser utilizada de forma equilibrada para que não retira } \\
\text { o principal fator da aula, o aprender. Deverá trabalhar junto a outros métodos } \\
\text { de aprendizagem não sendo objeto de diversão ou aula diferente, sem perder o } \\
\text { foco para a aprendizagem. }\end{array}$ \\
\hline P5 & $\begin{array}{l}\text { Servindo de suporte para o mesmo, tornando a aula mais prazerosa facilitando } \\
\text { assim, a aprendizagem. }\end{array}$ \\
\hline P6 & $\begin{array}{l}\text { As evoluções tecnológicas estão cada vez mais presentes no nosso cotidiano. } \\
\text { Por esse motivo o professor deverá analisar esses novos conhecimentos e } \\
\text { utilizar em sala de aula como ferramenta auxiliar no processo de ensino- } \\
\text { aprendizagem. }\end{array}$ \\
\hline P7 & $\begin{array}{l}\text { Quando bem empregada, dinamiza as aulas que consequentemente atraem a } \\
\text { atenção dos discentes e assim aumenta o aprendizado. }\end{array}$ \\
\hline P8 & Como o material extra para apresentação do conteúdo. \\
\hline
\end{tabular}
Fonte: Autoria própria

Quatro (P4, P5, P6, P7) dos oito entrevistados apresentam semelhança no que diz respeito à instrumentação contribuir para o processo de ensino e aprendizado, mencionando a importância dos recursos tecnológicos para o aprendizado dos alunos por promover a motivação, o interesse etc. Ressaltase que o sétimo professor entrevistado (P7) verifica a questão do aprendizado, porém destaca que somente se aplicada corretamente a instrumentação eletrônica surte efeito. Não dista do quarto professor (P4), cujo pensamento é a utilização com cautela para não tornar algo sério em "pura diversão" e perder o foco principal: o aprender.

Dois docentes (P1 e P3) consideram que os instrumentos tecnológicos servem de apoio para o professor em sala de aula, facilitando a apresentação dos conteúdos e contribuindo para a diversidade de recursos metodológicos do docente. Além de contribuir com o docente, o primeiro professor (P1) relata que a instrumentação eletrônica auxilia o processo de ensino e aprendizagem e, portanto, percebe-se que há uma intersecção com o pensamento dos docentes que consideram que o uso de tecnologia melhora o aprendizado dos alunos.

Por fim, mas não menos importante, o professor P2 exprime a ideia de manter-se atualizado para fazer bom uso dos recursos tecnológicos. Enquanto o oitavo educador (P8) entende a questão dos aparatos tecnológicos como um material extra, isto é, mais um tipo de recurso de ensino. Em uma análise minuciosa, percebe-se que esse último professor tem um pensamento que se estabelece uma certa relação ao entendimento dos professores P1 e P3, pois trata-se de uma ferramenta que auxilia a metodologia do docente.

Neste sentido, percebe-se que os professores entrevistados se interessam pela utilização dos recursos eletrônicos em sala, o que converge com que é destacado pelo autor Setzer (2001), propiciando a aula mais atraente e o processo de ensino e aprendizagem mais eficiente.

Na segunda pergunta, foi questionado se os docentes achavam viável lecionar os conteúdos matemáticos com interdisciplinaridade. Com isso, podemos verificar as respostas de cada docente na Tabela 2. 
Tabela 2 - Respostas dos professores entrevistados referente à segunda pergunta Pergunta 2: Você acha viável trabalhar conteúdos de matemática interdisciplinaridade? Justifique. Professor

P1 $\quad$ Sim. Mas tem que ter planejamento para não atropelar o processo.

P2 Sim. Para que os alunos possam sentir prazer em aprofundar seus estudos buscando uma melhor relação com as teorias e aplicações Matemáticas.

P3 Sim, pois a matemática é uma disciplina que podemos e necessitamos trabalhar com outras principalmente em projetos.

\begin{tabular}{|c|l|}
\hline P4 & $\begin{array}{l}\text { Sim, porém dependendo do grupo de alunos em trabalho com específicas desvantagens } \\
\text { de aprendizagem, a interdisciplinaridade pode causar prejuízos na aprendizagem. } \\
\text { Entretanto existindo nível qualitativo para o ano de estudo a interdisciplinaridade é um } \\
\text { agente positivo com bom nível de desenvolvimento do aluno }\end{array}$ \\
\hline P5 & $\begin{array}{l}\text { Sim. Isso mostra Principalmente ao educando que a matemática não é uma ciência } \\
\text { isolada e que pode ser trabalhada em várias disciplinas. }\end{array}$ \\
\hline P6 & $\begin{array}{l}\text { Sim. Essa abordagem interdisciplinar se relaciona para ampla compreensão de } \\
\text { conteúdos estudados a relação entre as matérias é muito importante para uma melhor } \\
\text { aprendizagem em sala de aula. }\end{array}$ \\
\hline P7 & $\begin{array}{l}\text { Com certeza, pois abrange muito mais o cognitivo do discente que vai aprender e } \\
\text { interrelacionar os conteúdos. }\end{array}$ \\
\hline P8 & $\begin{array}{l}\text { Trabalhando com outras disciplinas irá mostrar ao aluno como a matemática pode ser } \\
\text { evidenciada em diversas áreas. }\end{array}$ \\
\hline
\end{tabular}

Fonte: Autoria própria

Todos os entrevistados concordam com a possibilidade interdisciplinar que pode ser proporcionada à Matemática em sala de aula, todavia um professor (P1) deixa claro a ideia de que é necessário um planejamento preciso para sua aplicação. E outro (P4) que aponta limites para a prática interdisciplinar e afirma que mal inserida acarreta problemas na aprendizagem.

Os demais professores relatam a importância dessa prática como forma de ampliação do conhecimento entre as disciplinas através de projetos, relação entre teoria e prática e positividade em relação à compreensão dos conteúdos.

Um dos pontos destacados por Demo (2004) é a necessidade de tonar os conhecimentos mais próximos e relacionados, promovendo a interdisciplinaridade. Portanto, percebe-se que os professores entrevistados também defendem essa visão, o que contribui para o exercício profissional e o processo de ensino e aprendizagem.

$\mathrm{Na}$ terceira pergunta, foi interrogado se os entrevistados se consideram professor pesquisador, e de que forma a pesquisa pode agregar a prática docente. A Tabela 3 exibe a alegação de cada um.

Tabela 3 - Respostas dos professores entrevistados referente à terceira pergunta

\begin{tabular}{c|l}
$\begin{array}{c}\text { Pergunta 3: Você se considera um professor pesquisador? Se sim, quais os valores que a pesquisa pode } \\
\text { agregar a vida profissional do professor? Se não, descreva o porquê. } \\
\text { Professor }\end{array}$ \\
\hline P1 & $\begin{array}{l}\text { Rão, porque o sistema no qual trabalho não oferece condições, simplesmente nos obriga a } \\
\text { ser conteudista. }\end{array}$ \\
\hline P2 & $\begin{array}{l}\text { Sim. Pois como elas buscamos questões relativas a nossa prática com o objetivo de } \\
\text { aperfeiçoá-las e conhecer a realidade para transformá-la. }\end{array}$ \\
\hline P3 & Sim, a pesquisa amplia nossos conhecimentos. \\
\hline P4 & $\begin{array}{l}\text { Sim, pois a pesquisa pode permitir agregar outros conhecimentos, outras metodologias e } \\
\text { didáticas favorecendo a dinâmica das aulas bem como a resolução de situações-problemas } \\
\text { contextualizados tão necessária a realidade escolar. }\end{array}$ \\
\hline P5 & $\begin{array}{l}\text { Sim. Pois é através da pesquisa que nos enriquece e nos atualiza em meio às mudanças } \\
\text { constantes que ocorrem na educação. }\end{array}$ \\
\hline P6 & $\begin{array}{l}\text { Sim. A profissão de professor é muito árdua, mas para que realmente se faça a diferença o } \\
\text { professor precisa buscar na sua prática novas metodologias que irão contribuir para uma } \\
\text { melhor qualidade do ensino, e também atualização. }\end{array}$ \\
\hline P7 & $\begin{array}{l}\text { Sim. A pesquisa é essencial para o professor estar atualizado, não só na sua área como } \\
\text { também em diversas outras. }\end{array}$ \\
\hline P8 & $\begin{array}{l}\text { Sim. Um professor pesquisador sempre está antenado para a diversidade que a sua } \\
\text { disciplina pode abordar. }\end{array}$ \\
\hline
\end{tabular}


Com exceção do primeiro entrevistado analisado (P1) que afirma que não é professor pesquisador, restringindo seu ofício à sala de aula devido à falta de apoio oferecido pelo sistema no qual trabalha, todos os outros dizem-se pesquisadores. Os profissionais P2, P4 e P6 têm pensamentos que convergem, pois falam que a pesquisa é responsável pelo aperfeiçoamento da prática docente.

É válido ressaltar que as ideias dos professores pesquisadores sempre parte do pressuposto da ampliação de conhecimento e atualização contínua como ferramenta essencial à prática docente, o que entra em consonância com o pensamento de Demo (2004) e Tardif (1999). Essa mesma ideia desses dois estudiosos é facilmente observável na questão que diz respeito ao uso de aparatos tecnológicos.

$\mathrm{Na}$ quarta pergunta, foi indagado o que o entrevistado considera essencial para a formação de um professor da educação básica, conforme verifica-se a pergunta e a argumentação de cada professor na Tabela 4.

\begin{tabular}{|c|c|}
\hline \multicolumn{2}{|c|}{$\begin{array}{c}\text { Pergunta 4: } 0 \text { que você considera essencial para a formação de um professor da } \\
\text { educação básica? }\end{array}$} \\
\hline Professor & Resposta \\
\hline P1 & $\begin{array}{l}\text { Que ele seja orientado para trabalhar sempre com coerência, mas de } \\
\text { forma livre. }\end{array}$ \\
\hline P2 & $\begin{array}{l}\text { Promover o desenvolvimento e aprimoramento da capacidade } \\
\text { acadêmica e profissional dos docentes formadores. }\end{array}$ \\
\hline P3 & Antes de qualquer coisa gostar de ser professor. \\
\hline P4 & $\begin{array}{l}\text { Conhecimento sobre a sua própria área de atuação e em segundo } \\
\text { aspecto a didática inserida no ambiente escolar. }\end{array}$ \\
\hline P5 & $\begin{array}{l}\text { Estudar em uma instituição de qualidade onde o mesmo vise uma } \\
\text { melhor qualificação. }\end{array}$ \\
\hline P6 & $\begin{array}{l}\text { Procurar aperfeiçoamentos, para melhor desempenhar o seu } \\
\text { trabalho. }\end{array}$ \\
\hline P7 & A prática, lecionar é importante para a formação do docente. \\
\hline P8 & $\begin{array}{l}\text { Que ele domine não apenas o conteúdo, mas também tenha em } \\
\text { mãos uma boa didática. }\end{array}$ \\
\hline
\end{tabular}

Fonte: Autoria própria

Quanto a este questionamento as respostas foram fundamentalmente variadas. Dois professores (P2 e P5) consideram necessária uma instituição de ensino de qualidade, com professores qualificados, para que os licenciandos disponham de uma formação que supra as demandas do ensino básico, o que corrobora com Tardif (1991) ao contribuir com os saberes das disciplinas, curriculares e profissionais.

Outros dois profissionais (P4 e P8), relatam que para suprir as necessidades de lecionar no ensino básico é necessário conhecimento relativo aos conteúdos da disciplina ensinada, além de uma boa didática; portanto, as instituições devem promover esses dois aspectos durante a formação do profissional. As ideias de Tardif (1991), Pimenta (1996) e Perrenoud (1999) convergem para esse caminho, pois para a prática docente são necessários os múltiplos tipos de saberes de forma a solucionar as situações demandas pela profissão.

0 primeiro professor (P1) relata a importância da orientação, principalmente quanto a trabalhar de forma coerente e diligente, mas desde que haja liberdade. 0 profissional P3 não declara, efetivamente, os fatores essenciais para a formação do professor, mas destaca ser importante a apreciação pela profissão.

O docente P6 destaca a importância da formação contínua para o professor da educação básica, recorrendo a recursos que promovam aperfeiçoar a performance profissional. E o sétimo professor (P7) defende que o graduando deve ser submetido à prática da profissão para uma melhor formação. Novamente, ambos os docentes estão alinhados às ideias de Tardif (1999) quanto a formação contínua a fim de promover conhecimento profissional, além da experiência que possibilita a apropriação dos saberes curriculares e profissionais.

Na quinta e última pergunta, afirma-se que o professor precisa ser formulador de proposta própria, o que implica em construir um projeto didático, porém isto costuma ser um desafio para diversos professores, e diante disso, é questionado quais seriam as dificuldades em formular esses projetos. As repostas de cada docente estão dispostas na Tabela 5. 
Tabela 5 - Respostas dos professores entrevistados referente à quinta pergunta

Pergunta 5: 0 professor precisa ser formulador de proposta própria. Tal afirmação implica em construir um projeto didático. Porém, isso se torna um desafio para diversos professores. Quais são

\begin{tabular}{|c|l|} 
Professor & \multicolumn{1}{c}{$\begin{array}{c}\text { as dificuldades em formular tais projetos? } \\
\text { Resposta }\end{array}$} \\
\hline P1 & $\begin{array}{l}\text { Não. Ele deve seguir o projeto pedagógico da escola, mas tem a obrigação de dá uma } \\
\text { roupagem própria já que o projeto é flexível. }\end{array}$ \\
\hline P2 & Complexidade argumentativa e sofisticação do texto a ser produzido. \\
\hline P3 & $\begin{array}{l}\text { As dificuldades para elaborar o projeto são maiores no início da carreira do professor, } \\
\text { com passar do tempo vai ficando mais fácil. Tudo é uma questão de prática. }\end{array}$ \\
\hline P4 & $\begin{array}{l}\text { O professor esbarra na situação de encontrar gestores ou coordenadores escolares } \\
\text { que não possuem conhecimento a projetos didáticos da Matemática, somente os } \\
\text { projetos simplistas. Em segundo momento não existe uma instrumentação eletrônica } \\
\text { que permita ousar nas aulas, além do tradicionalismo. }\end{array}$ \\
\hline P5 & $\begin{array}{l}\text { A dificuldade não é formular um projeto didático, mas sim executá-lo, muitas vezes } \\
\text { por falta de recursos. }\end{array}$ \\
\hline P6 & Tempo e recursos. \\
\hline P7 & Nenhuma. \\
\hline P8 & O tempo! \\
\hline
\end{tabular}

Fonte: Autoria própria

Dois docentes (P4 e P5) destacam a falta de recursos como obstáculo. No entanto, o profissional P5 destaca que a dificuldade não é formular os projetos didáticos, mas executá-los pela falta de recursos; enquanto que o quarto professor ( $\mathrm{P} 4$ ) destaca escassez de recursos humanos qualificados na gestão, o que impõe dificuldades na construção de tais projetos, além de ressaltar a falta de recursos materiais, contribuindo para a dificuldade na aplicação de tais projetos. 0 professor P8 evidencia que o fator complicador na formulação dos projetos é a escassez de tempo. E ainda, o sexto professor (P6) ressalta que é a falta de tempo e recursos, ocasionando uma intersecção entre as justificativas supracitadas.

0 profissional $\mathrm{P} 2$ destaca que a formulação dos projetos didáticos é difícil devido a complexidade do texto produzido, enquanto o terceiro professor (P3) alega que a é falta de prática.

Um docente relatou que não há dificuldades em formular tais projetos, enquanto que outro se equivocou ao responder o questionamento por ter confundido projeto didático com projeto pedagógico da escola.

Dessa forma, percebe-se que os docentes não estão totalmente habituados com a construção de projeto didático, tal fato é decorre diretamente da escassez de tempo e recursos. Demo (2004) destaca a importância de o docente elaborar proposta própria, a qual necessita-se conhecimento pedagógico a fim de detectar as características da escola e adequar o ensino à realidade dos estudantes da melhor maneira, o que não é passível de ser constatado plenamente nos professores entrevistados.

\section{CONSIDERAÇÕES FINAIS}

Ao considerar os dados coletados por meio do questionário, percebe-se que os professores estão mais propensos a utilizarem recursos tecnológicos nas aulas ao argumentarem que facilitam o processo de ensino e aprendizagem e diversificam os recursos didáticos, o que converge ao que Setzer (2001) defende.

Constata-se que os docentes acreditam que é viável trabalhar conteúdos matemáticos com interdisciplinaridade, havendo, portanto, uma correlação com a visão de Demo (2004). Esta circunstância favorece o processo de significação e desenvolve a curiosidade do aluno e, consequentemente, o interesse em aprender.

A maioria dos professores declararam ser pesquisadores, atribuindo ao fato de aprimorar a prática docente, aquisição de conhecimentos etc. Tais alegações convergem para a formação contínua e construção dos saberes/conhecimentos descritos por Tardif (1999). Mas demonstrou-se de forma insuficiente o questionamento de forma crítica quanto aos materiais prontos (especialmente da internet) e a reconstrução desse conhecimento, como Demo (2004) defende ser característica de um professor pesquisador.

Quanto aos elementos essenciais para a formação do professor da educação básica, as respostas foram bem diversificadas. No entanto, os docentes declararam, essencialmente, a importância da competência profissional e dos tipos de saberes (das disciplinas, curriculares, profissionais e da experiência) para a 
formação, visto que esses itens contribuem para a prática docente.

Por fim, verifica-se que grande parte dos docentes não estão familiarizados com a formulação de um projeto didático, devido à escassez principalmente de tempo e recursos. Logo, foi possível notar a dificuldade para o professor ser formulador de tais propostas, fato este, que Demo (2004) reconhece que está ausente nos professores de educação básica em decorrência de não terem aprendido a pesquisar e/ou elaborá-los, porém considera essencial para o docente.

Portanto, têm-se expectativas promissoras quanto a melhoria do processo de ensino e aprendizagem da Matemática, visto que as concepções dos atuais docentes estão em crescente processo de transição para os campos idealizados pela comunidade da Educação Matemática. Com isso, espera-se que a educação seja formulada e conceituada de modo a tornar os professores cada vez mais proativos, pesquisadores, formuladores de propostas própria, que trabalhem a interdisciplinaridade, atualizem-se permanentemente etc.

\section{REFERÊNCIAS}

[1] Demo, P. Professor do futuro e reconstrução do conhecimento. 6⿳亠丷厂 ed. Petrópolis: Vozes, 2004.

[2] Perrenoud, P. Construir as competências desde a escola. Porto Alegre: Artes Médicas Sul, 1999.

[3] Pimenta, S. G.; Lima, M. S. L. Estágio e Docência. 4aㅗ ed. (Coleção Docência em Formação. - Série Saberes Pedagógicos). São Paulo: Cortez, 2009.

[4] Pimenta, S.G. Formação de professores: saberes da docência e identidade do professor. São Paulo: Faculdade de Educação da USP, 1996.

[5] Setzer, V. W. Meios Eletrônicos e Educação: Uma visão alternativa. São Paulo: Ed. Escritura, Coleção "Ensaios Transversais", vol. 10, 2001.

[6] Tardif, M. Saberes profissionais dos professores e conhecimentos universitários. Rio de Janeiro: PUC, 1999.

[7] Tardif, M.; Lessard \& Lahaye. Os professores face ao saber: Esboço de uma problemática do saber docente. Teoria \& Educação nº4, Porto Alegre: Pannônica, 1991. 


\section{Capítulo 22}

\section{Formação docente nas aprendizagens matemáticas dos Discentes no go ano do Ensino Básico}

\section{Valmiro de Santiago Lima \\ Sheyla Silva Thé Freitas \\ Maria dos Milagres Fernandes Diniz Chaves}

Resumo: A formação inicial docente aporta-se na formação continuada para suprir lacunas deixadas no decorrer dos estudos. 0 diagnóstico dessas debilidades foi verificado por meio das avaliações internas através de um projeto baseado na matriz de referência de matemática do MEC com descritores que avaliam competências e habilidades nesta ciência. As avaliações externas em larga escala da Prova Brasil do MEC, realizadas em anos ímpares, contempla a mesma matriz. Nesse sentido, os professores foram acompanhados após cada resultado proferido pelos alunos nos simulados testes, com objetivo de debater e planejar ações didáticas na superação de dificuldades encontradas pelos estudantes do 90 ano do ensino fundamental, vinculados a Secretaria de Educação Municipal de Tianguá. Foram constatados avanços significativos nas aprendizagens matemáticas dos aprendentes, em torno de 32\% para a proficiência adequada, e nas avaliações externas da Prova Brasil de 2015, aproximadamente 20\% dos educandos obtiveram proficiências adequadas e avançadas em matemática, oberva se que apenas $9 \%$ obtiveram este resultado no exame anterior. Portanto, a formação continuada do professor em cursos de pós-graduação especializações, mestrado, doutorado e os de aprimoramento metodológicos são necessários ao processo de ensino e aprendizagem.

Palavras-Chave: Formação docente, Aprendizagem discente, Avaliação. 


\section{INTRODUÇÃO}

O debate sobre a formação docente e suas implicações nas aprendizagens matemáticas pelos estudantes da educação básica é uma discussão que transita nos meios acadêmicos e fecundam pesquisas, que se estendem a todos os núcleos educacionais.

Nessa dimensão histórica, a matemática carrega o estigma de ser uma disciplina árida, difícil e complicada, por ser compreendida como uma ciência para poucos, ou para os mais inteligentes e na tentativa de superar este paradigma o profissional da educação deve aportar em metodologias e técnicas que seduzam os aprendentes à perceberem a significância destes conhecimentos no cotidiano.

Dessa forma, as aprendizagens matemáticas estudantis ao nível do nono ano do ensino básico foram diagnosticadas através das avaliações externas oficiais do MEC e confrontadas com avaliações internas através de um projeto pautado nas competências e habilidades nesta ciência. Sendo assim, o corpo docente, regentes na disciplina de matemática vinculados a Secretaria de Educação de Tianguá, município do Ceará foi acompanhado no período de um ano letivo, na vertente da formação continuada.

Nesse contexto, o objetivo de averiguar as implicações da formação docente nas competências matemáticas construídas nos educandos atreladas as práticas pedagógicas no espaço escolar. Nesse sentido, ancorou-se nas especificidades em diagnosticar na formação inicial e continuada do professor o fazer didático; verificar os fatores que interferem na aprendizagem matemática dos alunos do nono ano do ensino básico; descrever o significado das aprendizagens e o desenvolvimento das competências matemáticas conquistadas pelos discentes.

Este estudo é um recorte da tese de doutorado desenvolvida no programa de pós-graduação em Ciências da Educação da Universidad de la Integración de las Américas - UNIDA. Trata-se de uma aproximação ao tema referente à formação de professores, as competências e alfabetização matemática dos discentes lançando luz sobre suas similitudes e diferenças.

\section{AMBIENTE DO ESTUDO E METODOLOGIA}

A pesquisa transcorreu na rede de ensino pública da Secretaria Municipal de Educação de Tianguá (SME), a $360 \mathrm{~km}$ da capital do Ceará, Brasil. Trata-se de um estudo descritivo qualitativo e quantitativo no aporte de dados estatísticos.

Tendo como participantes professores regentes da disciplina de matemática e 89\% dos 1109 alunos do 9 은 ano da SME de Tianguá, referente ao ano letivo de 2015, o instrumental utilizado foi a aplicação do projeto "Aprova Brasil: Matemática Ensino Fundamental II" fundamentado nas competências e habilidades matemáticas, Matriz de Referência de Matemática conforme direcionamento do MEC.

Esse projeto contou com cinco encontros presenciais com os docentes, sendo o primeiro para apresentação do projeto, os outros quatros ocorreram bimestralmente após aplicação de simulados, testes pautados nos descritores da matriz de referência do MEC, para diagnosticar os avanços de aprendizagem nesta disciplina escolar, nos quais eram discutidas técnicas e metodologias para o ensino de matemática.

Ao final desse processo foram confrontados dados qualitativos e avanços nas avaliações dos resultados com o projeto, aos dados auferidos pela mesma plateia estudantil nas avaliações externas da Prova Brasil do MEC. As quantizações apresentaram avanços significativos nas duas comparações.

\subsection{AVALIAÇÃo}

Avaliar é uma prática constante que acontece nas diversas atividades cotidianas dos seres vivos, desde a escolha de uma moradia, de uma receita culinária, de um livro ao material didático escolar, etc.

No Brasil, as pesquisas em avaliações subdividem-se em duas, as internas inerentes às instituições escolares e as externas apresentam cunho mais abrangentes que direcionam nas tomadas de decisões de políticas públicas educacionais que sejam municipais, estaduais ou nacionais.

As avaliações em larga escala também passam a ser descaracterizadas por parte de alguns professores que as compreendem somente pelo ranking que a escola ocupa no campo educativo e são quase que forçados a trabalhar nesse sentido. Contudo, reconhecem que faltam verdadeiros incentivos para que os resultados sejam utilizados com efetividade e, consequentemente, alcancem melhorias na 
qualidade da educação no país, como muitos educadores, estudantes e familiares esperam (SILVA; SILVA; TROMPIERI FILHO, 2017, p. 64).

Nesse sentido, as avaliações externas são instrumentos que promovem diagnósticos no incremento às políticas educacionais pelas secretarias de educação em todos os níveis da federação.

Nessa vertente, a avaliação escolar tem estado presente ativamente em todos os momentos nas instituições escolares, no qual estão envolvidos docentes e discentes há muito tempo, professores avaliam seus alunos para diagnosticar o nível de aprendizagem, já conquistado e aprendido pelos educandos para auxiliá-los no processo da aprendizagem. Sendo assim, a avaliação faz-se necessária,

a reorientação imediata da aprendizagem, caso sua qualidade se mostre insatisfatória e o conteúdo, habilidade ou hábito, que esteja sendo ensinado e aprendido, seja efetivamente essencial para a formação do educando; o encaminhamento dos educandos para passos subsequentes da aprendizagem, caso se considere que, qualitativamente, atingiram um nível da satisfatoriedade no que estava sendo trabalhado (LUCKESI, 2015, p. 77).

Dessa forma, a avaliação é um agente integrador na formação discente e elemento essencial na construção pedagógica da prática do professor no exercício do ofício de ensinar e promover uma aprendizagem significativa de qualidade para o estudante. Logo, avaliar é conscientizar uma ação educativa "avaliação é um processo pelo qual se procura identificar, aferir, investigar e analisar as modificações do comportamento do aluno, do educador, do sistema confirmando se a construção do conhecimento" (SANT'ANNA, 2017, p. 31), que seja este teórico ou prático.

Essas avaliações são pertinentes, pois proporcionam uma visão ampliada da educação em relação à aprendizagem do discente, promovendo qualidade no processo de ensino e aprendizagem, favorece a tomada de decisões em políticas públicas por gestores em vários níveis administrativos educacionais.

O significado da avaliação é uma nobre tarefa para o docente, que tem que discernir entre medir e avaliar, mensuração deve aporta-se no aspecto qualitativo em detrimento da quantização, o ensinante,

ao pensar sobre o dever que tenho, como professor, de registrar a dignidade do educando, sua autonomia, sua identidade em processo, devo pensar também [...] em como ter uma prática educativa em que aquele respeito, que sei dever ter ao educando, se realize em lugar de ser regulado. Isso exige de mim uma reflexão crítica permanente sobre minha prática através da qual vou fazendo a avaliação do próprio fazer com os educandos (FREIRE, 2004, p. 64).

Em prol de uma formação cidadã de crianças e adolescentes faz-se necessário que o educador promova um desenvolvimento crítico e participativo, a construção de conhecimentos específicos das disciplinas que compõem o currículo escolar para a aprendizagem do estudante. Nessa linha de raciocínio a avaliação é "de modo geral, como saber situar cotidianamente, numa certa ordem hierárquica, o valor de algo enquanto meio (mediação) para a realização da vida do(s) sujeito(s) em questão, no contexto dos valores culturais e, no limite, dos valores universais" (CASALI, 2007, p. 10), na perspectiva do sujeito compreendido como cidadão integral.

Dessa maneira, as escolas passam a utilizar o "teste escrito e o sistema de notação para dar maior credibilidade pública, transparência e rigor no julgamento dos resultados, com isso eles acabam interferindo nos currículos e nas propostas pedagógicas" (HORTA NETO, 2010, p. 85). Percebe-se que a escola ocupa um papel fundamental na aquisição de competências e habilidades para a plena participação destes na sociedade, em um mundo globalizado de trabalho como nas relações sociais, políticas e culturais.

A avaliação do processo de ensino e aprendizagem discente é realizada de forma contínua, cumulativa e sistemática na escola, que deve priorizar a prática de investigação buscando identificar os conhecimentos construídos e as dificuldades afloradas na forma dialógica do tripé professor, aluno e conhecimento, no qual o contexto é o objeto de análise para a tomada de decisão.

Salienta-se que, a avaliação escolar inicia e permeia todo o processo e o conclui em um processo macro, existem várias formas para avaliar a prova dissertativa nas quais o aluno coloca suas respostas com suas palavras o que ele entendeu sobre o assunto, na autoavaliação o estudante irá analisar e dizer como foi seu desenvolvimento, já na prova objetiva o educando marca uma das opções e as demais devem constituir distratores. 
O item de múltipla escolha requer que o estudante selecione uma única opção de resposta entre várias apresentadas. Essa opção, denominada chave de resposta ou gabarito, precisa ser inequivocamente certa, enquanto as demais devem ser incorretas, mas plausíveis (RABELO, 2013, p. 181).

Nesse contexto, os distratores são instrumentos qualitativos para o diagnóstico dos caminhos adotados pelo discente nas tomadas de decisões de suas respostas a um item avaliado, fugindo da estruturação adequada e correta que o leva a indução ao erro, caracterizando um aprendizado equivocado ou falho.

Ressalta-se que, a estrutura organizacional das avaliações externas em larga escala do Ministério da Educação ocorre por níveis educacionais. Sendo assim, o SAEB é composto por três avaliações externas em larga escala em níveis de alfabetização, ensino fundamental e ensino médio, cujo objetivo principal é avaliar a Educação Básica brasileira e contribuir para a melhoria de sua qualidade e universalização. Além disso, o organograma das avaliações externas em larga escala, "oferece dados e indicadores que possibilitem maior compreensão dos fatores que influenciam o desempenho dos alunos nas áreas e anos avaliados" (BRASIL, 2013, p. 13). Constata-se que esse diagnóstico favorece tomadas de decisões e implementações de políticas públicas em favor da melhoria da educação e elevação da qualidade na formação inicial e continuada docente.

\subsection{FORMAÇÃO DOCENTE}

A humanidade desde os primórdios de sua existência aprende e ensina métodos e técnicas para sua subsistência e adaptabilidade no seu processo da perpetuação da espécie e evolução. Essas aprendizagens são efetivadas, quer seja de forma intuitiva ou com uma intencionalidade de fim, e possibilita que o ser humano desenvolva e aperfeiçoe técnicas na confecção de ferramentas para caça e defesa, na observação dos fenômenos naturais, a descoberta do fogo foi fundamental na proteção individual, do grupo familiar e na proteção contra predadores naturais. Essas aprendizagens de forma intuitiva eram assimiladas e imitadas por elementos do grupo e por outros indivíduos.

Nessa perspectiva, brota a figura do professor informal, no qual homens e mulheres tinham papéis específicos na estrutura social. Os homens na procriação, defesa, caça, pesca entre outras, as mulheres nos cuidados com as crias, elaboração, confecção dos alimentos entre outras funções.

0 processo evolutivo do ser humano passa por várias fases, dos aldeamentos às cidades e cidades estados. Emerge a necessidade da divisão de responsabilidade dentro de um organograma funcional social de tarefas de produção e administração de uma forma geral, assim, surge o papel do professor formal.

Nesse contexto, o papel do professor é difundir a instrução, transmitir os conhecimentos acumulados pela humanidade e sistematizá-los logicamente, assim "a escola surge como antídoto à ignorância, logo, um instrumento para equacionar o problema da marginalidade” (SAVIANI, 2012, p. 6), essa é a tarefa de ensinar deixada ao ensinante, muitas vezes acaba assumindo o papel de juiz com poderes de absorver ou condenar, aprovar ou reprovar através dos instrumentos das avaliações, traz uma série de contradições, pois, o ensino é concebido como uma técnica de combinar de modo eficaz, meios e fins considerados evidentes e naturais. 0 ensino como uma interação social e necessária em uma reconstrução da realidade pelos docentes e discentes.

A formação inicial é um processo estruturado em normas bem definidas. A formação do professor passa por várias vertentes e a,

experiência de magistério é fundamental para a orientação didática do professor, porque ela aguça a percepção docente fornecendo indicações de ordem didática, tais como: dosagem de nível de conteúdo a ser ministrado, ritmo de aula, pontos de aprendizagem mais difíceis, exemplos mais eficientes à aprendizagem, livros didáticos mais adequados à realidade na qual leciona, entre outros (LORENZATO, 2010, p. 9).

Desse modo, o educador em sua formação pautada em uma matriz curricular bem estruturada academicamente e contemplando os conteúdos específicos e didáticos com prática no decorrer do curso, na perspectiva de munir este profissional da educação com experiências e vivências de sala de aula, com o intuito de melhorar o ensino.

os cursos de licenciatura resultaram fortemente marcados pelos conteúdos culturais-cognitivos, relegando o aspecto pedagógico-didático a um apêndice de 
menor importância, representado pelo curso de didática, encarado como uma mera exigência formal para a obtenção do registro profissional de professor (SAVIANI, 2009, p. 147).

Nesse contexto, o professor formado para atuar na disciplina de Matemática é necessário que tenha conhecimentos aprimorados e específicos na área de atuação, tenha a capacidade para tramitar nas demais áreas de conhecimentos, essa fundamentação ocorre através de livros, revistas, informações da mídia escrita e televisiva, internet, encontros científicos e outros recursos, pois "o saber a ser ensinado provenha ou não de um corpo científico de conhecimentos, o trabalho de ensinar requer a construção de uma percepção peculiar do objeto de ensino" (MOREIRA; DAVID, 2007, p. 18), assim a matemática escolar constitui essencialmente de uma adaptação dos conceitos, técnicas e métodos da matemática científica, de suas normas e valores sujeitos a vigilância epistemológica dentro de uma didática adequada.

\section{RESULTADOS}

As análises dos dados propiciaram o diagnóstico do rendimento escolar inicial dos discentes na disciplina de matemática na compreensão de suas competências e habilidades no 9o ano do Ensino Fundamental e carência na compreensão leitora nesta ciência, pelos alunos.

O projeto "Aprova Brasil: Matemática Ensino Fundamental II" favoreceu um salto na qualidade de ensino dos professores regentes da disciplina de matemática e nas aprendizagens discentes do 9o ano do Ensino Fundamental, como se observa no Gráfico 1.

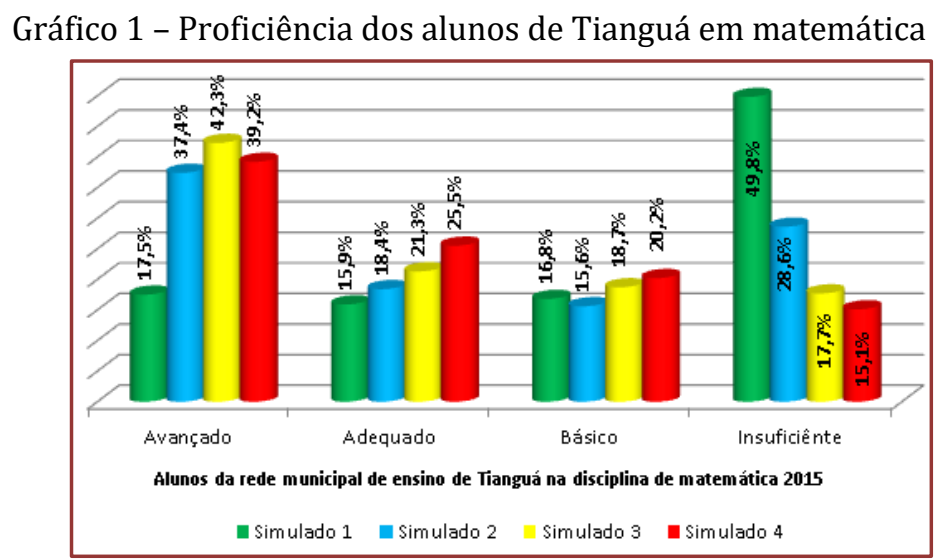

Fonte: Elaboração própria, 2015.

As avaliações dos quatro simulados no transcorrer de 2015, constatou-se a evolução das competências matemáticas no quantitativo de $17,5 \%$ para $39,2 \%$ no nível avançado, no primeiro ao quarto bimestre, e a redução significativa em números percentuais de 49,8\% para 15,1\% nas dificuldades de aprendizagem desta disciplina escolar pelos alunos.

Neste contexto, os avanços nas competências e habilidades matemática implicaram nas avaliações externas do MEC, como se observa no Gráfico 2, nas proficiências conquistadas pelos discentes do 9o ano na Prova Brasil de 2015.

Gráfico 2 - Proficiências dos alunos de Tianguá em matemática

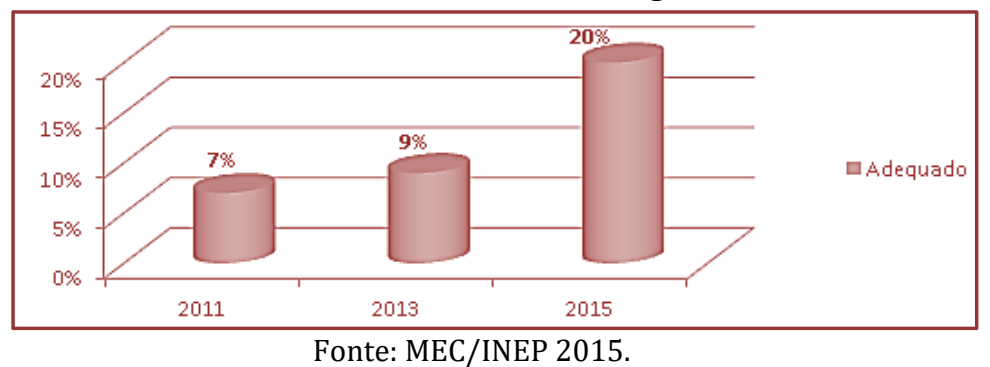


Os avanços nas aprendizagens matemáticas dos estudantes do ano de 2011 para 2013 foi de 2\%, com o aporte do projeto na vertente da formação continuada dos docentes, a evolução do exame anterior para o de 2015 foi de $11 \%$ nas aprendizagens estudantis.

Dessa forma, a formação inicial do professor em si, não atende plenamente as exigências na construção dos conhecimentos matemáticos na sala de aula em parceria com os alunos, a formação continuada desse profissional torna se parâmetro fundamental e necessário ao exercício desta função educacional.

\section{CONCLUSÃO}

Através dos resultados, foi possível ver que a formação do docente inicial não atende plenamente as necessidades do exercício do magistério, a formação continuada tem a função de suprir as lacunas deixadas pela primeira no complemento de técnicas e metodologias adequadas ao ensino e aprendizagem dos discentes em formação.

Dessa forma, a avaliação e exames apresentam dois instrumentos com características próprias. A avaliação interna instrumentaliza o professor no seu replanejamento contínuo, a avaliação externa em larga escala favorece o incremento de políticas públicas educacionais. Sendo assim, os exames pautados nos descritores da matriz de referência matemática do MEC, fomentam o diagnóstico do nível de aprendizagem matemática do estudante em suas competências e habilidades.

Contudo, quando aqueles que fazem a educação aportam-se nas teorias e praticam metodologias adequadas no ambiente escolar, potencializam melhorias nas aprendizagens discentes, estabelecendo parcerias de professores e alunos para a construção do conhecimento matemático.

\section{REFERÊNCIAS}

[1] Brasil (2013). Prova Brasil: Avaliação do Rendimento Escolar. Brasília: MEC.

[2] Casali, Alípio (2007). Fundamentos para uma avaliação educativa. In: Cappelletti, Isabel. Avaliação da aprendizagem: discussão de caminhos. São Paulo: Editora Articulação.

[3] Horta Neto, João Luiz (2010). Avaliação externa de escolas e sistemas: questões presentes no debate sobre o tema. Revista Brasileira de Estudos Pedagógicos, Brasília, v. 91, n. 227, p.84-104.

[4] Freire, Paulo (2004). Pedagogia da autonomia: saberes necessários à prática educativa. 30. ed. São Paulo: Editora Paz e Terra.

[5] Lorenzato, Sérgio (2010). Para aprender Matemática. 3. ed. São Paulo: Autores Associados.

[6] Luckesi, Cipriano Carlos (2015). Verificação ou Avaliação: o que pratica a Escola?. Revista Gestão do Currículo. Juiz de Fora, CAEd, Juiz de Fora, v. 1, n. 1, p.71-80.

[7] Moreira, Plínio Cavalcanti; David, Maria Manuela Martins Soares (2007). A formação matemática do professor: Licenciatura e prática docente escolar. Belo Horizonte: Editora Autêntica.

[8] Sant'Anna, Ilza Martins (2017). Por que avaliar? Como avaliar? Critérios e instrumentos. 17. ed. 2aㅡ reimpressão. Petrópolis: Vozes.

[9] Saviani, Dermeval (2012). Escola e democracia. 42. ed. Campinas: Autores Associados.

[10] _ (2009). Formação de professores: aspectos históricos e teóricos do problema no contexto brasileiro. Revista Brasileira de Educação. Rio de Janeiro, v. 14, n. 40, p.143-155.

[11] Silva, Jáderson Cavalcante da; Silva, Jocyana Cavalcante da; Trompiere Filho, Nicolino (2017). Debate sobre avaliação e exame no ambiente escolar. In: SILVA, Lucas Melgaço da; Ciasca, Maria Isabel Filgueiras Lima (Org.). As voltas da avaliação educacional em múltiplos caminhos. Fortaleza: Educe. Cap. 4. p. 63-84. 


\section{Capítulo 23}

A Importância do PIBID na formação-docente no ensino da Matemática: Um relato de experiência em uma Escola Pública no Estado do Pará

\section{Darlan Douglas Barros Pereira \\ Ismael Smylle da Silva Quirino}

Resumo: 0 presente trabalho objetiva-se por ressaltar a importância do incentivo que é proposto pelo PIBID (Programa de Bolsas de Iniciação à Docência). Com este programa foi possível uma experiência, na qual nos proporcionou a observação diária do trabalho docente, o que nos instigou para a eleboração de uma atividade diferenciada para os alunos do $8^{0}$ ano do ensino fundamental, em uma escola estadual localizada no município de Igarapé-Açú (PA), esta atividade abordou a Geometria, sendo que foi trabalhado dentre esta área de conhecimento, o reconhecimento das figuras geométricas e ângulos. Esse escrito também nos mostra o diferencial significativo que o PIBID tem para os licenciandos.

Palavras-chave: PIBID. Extensão. Importância. Docência. 


\section{INTRODUÇÃO}

O presente trabalho surge com o intuito de mostrar a importância do programa institucional de bolsas de iniciação à docência (PIBID) para a formação do graduando licenciando, pois por meio do programa é possível a experiência em sala de aula, onde analisar de perto essa realidade é de suma relevância, com isso, a pesquisa demarcará a importância do programa para os alunos de graduação na construção de subsídios que auxiliem sua formação docente.

Logo, a partir dessa experiência foi possível analisar como agir em determinadas situações em sala de aula, onde surge a indagação de discutir a respeito da prática docente, observar o funcionamento de uma instituição de ensino e quais os principais problemas enfrentados no cotidiano educacional inquietações estas que levaram a ressaltar mais uma vez a relevância de programas como o PIBID pois os alunos que fazem parte do programa além da teoria aprendida na academia, contam com a experiência prática, que é conhecer o ambiente e a realidade, bem como observar o professor regente e sua maneira de lidar com determinadas situações que podem surgir.

PAIS (2000) ressalta a grande importância da formação do professor para realizar uma análise correta de quais os materiais adequados para utilizar no processo de ensino, visando a melhor compreensão do aluno e assim não deixando tantas lacunas no processo educacional, pois uma boa escolha pode facilitar o próprio trabalho docente, porém uma escolha errônea para esse processo pode, além de dificultar o ensino, prejudicar os alunos, assim, ressalta-se a relevância deste escrito, que objetiva-se a discursão das relevâncias de iniciação à docência na vida acadêmica dos graduandos, com isso, a pesquisa é de cunho qualitativo e conta também com um prévio levantamento bibliográfico que ressaltam o debate trazido neste relato de experiência.

\section{METODOLOGIA}

O presente trabalho é fruto de uma pesquisa qualitativa, pois refere-se a uma questão particular relacionada a uma realidade singular e específica (MINAYO, 2002) e nesse caso este escrito apresenta a experiência de estágio no programa PIBID na escola pública estadual Cônego Calado que está localizada no nordeste paraense no município de Igarapé-Açu no estado do Pará, onde foram utilizadas técnicas como a observação participante nas salas de aula, o que proporcionou uma aproximação com a experiência docente por meio do estágio supervisionado sob orientação de um docente da escola, onde teve-se a oportunidade de vivenciar a rotina do ambiente escolar ressaltando a importância do programa na formação acadêmica de graduandos pibidianos.

A pesquisa possui caráter descritivo por ter como intuito a descrição da vivência no programa e, conta inicialmente com uma prévia pesquisa bibliográfica na busca por fundamentação teórica para as questões apresentadas neste escrito e na busca de salientar a relevância de programas de iniciação à docência para os alunos de graduação, sendo os principais autores Zaqueu (2014), PAIS (2000) e outros que dão subsídios para esta pesquisa.

A observação participante também fez parte desta pesquisa sendo "O modelo de observação participante consiste na participação real do pesquisador com a comunidade ou grupo. Ele se incorpora ao grupo, confunde-se com ele. Fica tão próximo quanto um membro do grupo que está estudando e participa das atividades normais deste" (LAKATOS, p 194, 2003), esta afirmativa demonstra a aproximação do cotidiano dos alunos, o que consiste em uma harmônica relação entre graduando estagiário e alunos, acarretando em uma boa dinâmica nas aulas. Com isso, buscar-se com este escrito relatar uma experiencia vivenciada no programa PIBID com o intuito de salientar sua importância enquanto programa de iniciação a docência e suas contribuições para educação matemática.

\section{REFERENCIAL TEÓRICO}

\subsection{A IMPORTÂNCIA DO PROGRAMA INSTITUCIONAL DE BOLSAS DE INICIAÇÃO À DOCÊNCIA}

Como afirma Zaqueu (2014) o programa institucional de bolsas de iniciação à docência, tem dois papéis essências, o primeiro é o de propor uma educação básica de qualidade na escola pública, pois os estagiários (bolsistas) e (voluntários) que estarão atuando em sala de aula, têm a função de auxiliar o professor supervisor nas atividades, sendo assim conseguem suprir algumas lacunas que seriam deixadas pelo professor quando ele trabalha só, ou seja, quando a classe não possui estagiários do programa, o que 
demonstra que o programa contribuiu para a formação do aluno estagiário e também contribui com a turma a qual estagia, com a aplicação de dinâmicas e atividades.

O segundo papel do Pibid é a formação de professores, em que os bolsistas e voluntários são inseridos na sala de aula para experiência prática e que consequentemente será relacionado com as teorias estudadas no âmbito acadêmico, assim com base na análise entre teoria e prática, farão uma observação do que é viável a ser utilizado ou não e, com isso tem-se um ganho importante e próprio do programa, o incentivo à docência.

\subsection{ATIVIDADES APLICADAS E SEUS RESULTADOS}

Como resultado do PIBID foi possível vivenciar práticas docentes com a turma a qual ocorreu o estágio, onde as tarefas propostas limitaram-se a trabalhar os conteúdos de reconhecimento de figuras geométricas e seus respectivos ângulos, e as definições de ângulos complementares, suplementares e replementares.

No momento que destinou-se a pensar as atividades foram feitas as seguintes indagações; de que forma aplicar uma atividade na qual ao mesmo tempo que avalia-se os alunos a atividade venha fazer parte do processo de construção do conhecimento sobre o conteúdo abordado de forma recreativa, onde os mesmos possam observar o seu próprio cotidiano, logo, foi pensada de forma metodológica a atividade a ser aplicada e para a sua elaboração foi utilizado além do plano de aula do professor supervisor o livro "praticando matemática" de Alvaro Andrini (1989) disponibilizado pelo professor supervisor e utiliza pra criar seus planos de aula e por consequência suas atividades.

A primeira atividade teve como objetivo o reconhecimento das figuras geométricas e seus respectivos ângulos através da visão e do tato, sendo que as figuras poderiam ser manipuladas pelo aluno, para assim analisarem da maneira que julgaram melhor para o próprio entendimento, sendo assim o agente totalmente ativo do próprio no processo de construção de conhecimento.

Na segunda atividade teve como proposta principal notar se os educandos conseguiram aprender de fato as definições dos ângulos complementares, suplementares e replementares, sendo que essa atividade assim como a primeira para saber por meio dos dois sentidos, a visão e o tato, pois os ângulos estavam dispostos em forma de material controlável, e com isso os alunos analisaram da maneira que julgavam melhor para seu entendimento e compreensão dos ângulos abordados e sendo assim tronando também ativo na construção de conhecimento.

A terceira e última atividade tinha como principal objetivo fazer com que esses mesmo alunos conseguissem notar os ângulos e formas geométricas no seu cotidiano, fazendo assim esse aprendizado se tornar significativo para eles, essa atividade contou com um dos principais sentidos do ser humano a visão, pois eles tiveram que analisar em duas imagens, sendo que essas eram imagens de patrimônio histórico do município de Igarapé Açu-PA, com isso trouxemos imagens de locais que eles costumam ver no dia a dia, e com base nos conhecimentos que tinham e que construíram nas duas outras atividades anteriores, eles analisaram as imagens com intuito de notar esses ângulos e assim nomear cada ângulo por eles encontrados.

Quando foram pensadas essas atividades, o principal objetivo foi o de aguçar os outros sentidos desses alunos, e com isso mostrar que de fato não se aprende só escrevendo e ouvindo, porém que há variadas maneiras de aprender e com isso foi proposto essas tarefas com intuito de analisar o comportamento desses alunos ao se depararem com uma forma de ensino diferenciado das propostas antes vistas por eles. Como essa tarefa foi possível analisar a interação que os alunos demonstram com os próprios alunos com o intuito de resolverem para o problema posto o que marcou uma forte interação na construção do conhecimento obtido.

\section{CONSIDERAÇÕES FINAIS}

Como resultado deste relato de experiência destaca-se o grande aprendizado das práticas docente que como pibidianos, no qual foi proposto um grande desafio com intuito de nos deixar livre, para assim, de acordo com vivência e aprendizado em sala de aula, elaborar uma atividade pertinete aos assuntos já abordados pelo professor na classe, e além disso fomos instigados a construir uma atividade na qual os alunos também entendesse que o conteúdo estudado na sala de aula não é abstrato, logo a atividade propos ligar os conteúdos abordados em sala com o cotidiano de cada um. 
Ressaltar-se com esta pesquisa a relevância da experiencia obtida com o PIBID no que concerne a melhoria do processo de ensino e aprendizagem do aluno graduando, tendo em vista a experiência que o programa propõe vale ressaltar que isto reflete em uma boa formação acadêmica do pibidiano que participa de forma ativa na iniciação docente.

\section{REFERÊNCIAS}

[1] Andrini, Alvaro. Praticando Matemática: 8a Série. São Paulo: Editora Brasil, 1989.

[2] Cunha, Cibele Faria. Marcatto, Flávia Sueli Fabiani. Formação inicial de professores de matemática e os desafios atuais: entre o pibid, a crise e as novas diretrizes nacionais para a formação docente. Evento Nacional de Educação Matemática, 2016.

[3] Pais, Luiz Carlos. Uma análise do significado da utilização de recursos didáticos no ensino da geometria. Reunião da Anped, 2000.

[4] Lakatos, Eva Maria. Marconi, Marina de Andrade. Fundamentos da metodologia cientifica. -5. Ed.- São Paulo: Atlas 2003.

[5] Minayo, S. C. M. et al. (orgs.). Pesquisa social: teoria, método e criatividade. Petrópolis: editora vozes, 2002.

[6] Zaqueu, Ana Claudia Molina. O Programa Institucional de Bolsas de Iniciação à Docência (PIBID) na formação de professores de matemática: perspectivas de ex-bolsistas- Rio Claro, 2014. 


\section{Capítulo 24}

A importância de atividades lúdicas para a aprendizagem da matemática por crianças do Ensino Fundamental: Uma experiência a partir do PIBID

\section{Graziela Aquino do Nascimento \\ Lindiane Duarte da Silva \\ Pascoal Eron Santos de Souza}

Resumo: A matemática infelizmente ainda é vista, por um número significativo de discentes, como uma área de conhecimento complexa e de difícil assimilação. Essa concepção, muitas vezes, é construída a partir das experiências que os sujeitos têm na escola. Neste sentido, cabe às instituições de ensino e aos professores desenvolverem metodologias que desmistifiquem essa visão acerca da matemática. Isso pode ser alcançado por meio da utilização de instrumentos pedagógicos, como jogos e brincadeiras, que têm potencial de tornar prazeroso o ato de aprender, favorecendo a participação ativa dos estudantes no processo de construção do conhecimento. Este trabalho discute sobre alguns resultados alcançados com um projeto didático em desenvolvimento que tem como propósito articular atividades lúdicas para o ensino de matemática. 0 projeto intitulado A importância de atividades lúdicas para a aprendizagem da matemática por crianças do ensino fundamental: uma experiência a partir do Pibid" está sendo realizado em uma escola pública do município de Senhor do Bonfim - Bahia, em articulação com o Programa de Bolsas de Iniciação à Docência (PIBID), da Universidade do Estado da Bahia - UNEB/Campus VII. A partir das atividades, é possível perceber que dificuldades na aprendizagem da matemática são recorrentes na escola, sobretudo no que se refere a operações que exigem raciocínio complexo como a multiplicação e a divisão. Contudo, quando estes conteúdos são abordados por meio de atividades lúdicas, os estudantes apresentam níveis satisfatórios de aprendizagem. 0 uso de jogos e brincadeiras, em contextos pedagógicos, não devem ser tomados como meros elementos de entretenimento, mas como ferramentas capazes de tornar dinâmico e prazeroso o processo de ensino-aprendizagem.

Palavras-chave: Ensino de matemática, Atividades lúdicas, Anos iniciais do ensino fundamental. 


\section{INTRODUÇÃO}

Existe entre os estudantes da educação básica o mito de que a matemática é uma área de conhecimento complexa e de difícil compreensão. Na verdade, a maneira como os conhecimentos matemáticos são abordados na escola tem reflexos na aprendizagem do indivíduo. Neste sentido, cabe às instituições de ensino e aos professores desenvolverem metodologias que desmistifiquem essa visão que o senso comum constrói acerca da matemática. Isso pode ser alcançado por meio da utilização de instrumentos pedagógicos, como jogos e brincadeiras, que têm potencial de tornar prazeroso o ato de aprender, favorecendo a participação ativa dos estudantes no processo de construção do conhecimento.

Diante desse contexto, Cunha (2001, p.14), citado por Silva e Angelim (2017, p. 899), afirma que: "O brincar desenvolve as habilidades da criança de forma natural, pois brincando aprende a socializar-se com outras crianças, desenvolve a motricidade, a mente, a criatividade, sem cobrança ou medo, mas sim com prazer". Entende-se que através do lúdico, utilizando-se brincadeiras para o ensino da matemática, será potencializado nas crianças o desenvolvimento do raciocínio lógico, bem como o interesse pela matemática, por proporcionar situações de aprendizagem de uma forma atrativa e divertida, relacionando conhecimentos formais a atividades cotidianas dos estudantes, podendo tornar mais significativas as atividades que envolvem cálculo, por exemplo.

Ainda sobre a aprendizagem, Klausen (2017, p. 6405) diz que: "para que uma aprendizagem ocorra, ela deve ser significativa, o que exige que seja vista como a compreensão de significados, relacionando-se às experiências anteriores e vivências pessoais das crianças [...]". Nesse sentido, a escola deve trabalhar com os conhecimentos prévios do aluno, considerando a sua experiência anterior e valorizando a participação da família no processo de formação dos estudantes.

Diante desse contexto, como estudantes do curso de pedagogia, atuando como bolsistas do Programa Institucional de Bolsas de Iniciação à Docência, da Universidade do Estado da Bahia - UNEB/Campus VII, em uma escola pública do município de Senhor do Bonfim, no interior do estado da Bahia, propusemos desenvolver um projeto didático articulando atividades lúdicas e o ensino de conteúdos matemáticos para crianças dos anos iniciais do ensino fundamental.

0 referido projeto, intitulado "A importância de atividades lúdicas para a aprendizagem da matemática por crianças do ensino fundamental: uma experiência a partir do Pibid", tem como objetivo aproximar os alunos dos anos inicias de conhecimentos matemáticos por meio de atividades lúdicas, possibilitando processos de aprendizagem significativa e contribuindo para desmistificar a concepção da matemática como uma área difícil de ser compreendida pelos estudantes. É importante destacar que as ações do projeto ainda estão em desenvolvimento com previsão de conclusão para este ano de 2019. Assim, o propósito deste texto é discutir sobre alguns resultados alcançados até o momento, e refletir sobre a relação entre aprendizagem de conteúdos matemáticos e a utilização de atividades lúdicas como instrumento pedagógico.

\section{METODOLOGIA}

As experiências aqui relatadas surgiram a partir do desenvolvimento de um projeto didático em uma escola pública de anos iniciais do ensino fundamental, buscando estimular crianças a aprenderem conhecimentos matemáticos por meio de atividades lúdicas. A escola está localizada em um bairro periférico da cidade de Senhor do Bonfim, situada no território do Piemonte Norte do Itapicuru, no interior do estado da Bahia. A maior parte dos estudantes desta instituição advém de famílias com baixo poder aquisitivo e que passam por problemas sociais associados ao desemprego e a situações de vulnerabilidade.

Nas dependências da escola foi organizado um espaço temático com decoração específica em uma sala de aula destinada exclusivamente para a realização das atividades pedagógicas do projeto. Dentre os elementos disponibilizados neste espaço, podemos mencionar: (mural da tabuada, dominó matemático, jogo da trilha, jogo: onde posso chegar? sala ornamentada com números, formas geométricas, sinais das operações e seus respectivos nomes).

Após a organização do espaço, com a montagem da sala ambiente, organizamos um cronograma para sistematizar a participação dos estudantes no projeto. Ao todo, foram envolvidos cento e vinte e um (121) estudantes do $1^{\mathrm{O}}$ ao $5^{\mathrm{O}}$ ano do ensino fundamental. 
As visitas à sala ambiente geralmente tinham duração de quarenta e cinco (45) minutos, com a participação de vinte (20) estudantes em média. Os grupos de discentes eram acompanhados por uma professora, mas as atividades na sala ambiente eram desenvolvidas por nós, bolsistas do PIBID.

Este estudo foi desenvolvido a partir de um paradigma qualitativo de pesquisa, no qual a observação e o diário de bordo forram os principais instrumentos para o processo de coleta de dados. Sobre a observação enquanto instrumento de estudos qualitativos, aponta Gil (2008, p. 16): "pode ser considerado o mais primitivo, e consequentemente o mais impreciso. Mas, por outro lado, pode ser tido como um dos mais modernos, visto ser o que possibilita o mais elevado grau de precisão nas ciências sociais". As observações, organizadas de forma sistemática, possibilitaram o registro das experiências vivenciadas no âmbito do projeto, permitindo-nos compreender os processos construídos na relação entre os sujeitos com as atividades propostas, dos sujeitos com os conhecimentos e dos sujeitos entre si. Elementos essenciais no desenvolvimento da aprendizagem em contextos pedagógicos.

\section{DESENVOLVIMENTO}

A matemática nos anos iniciais é de suma importância para o desenvolvimento cognitivo dos alunos/as. Nesta perspectiva, a escola desempenha um papel fundamental neste processo, pois tem a responsabilidade de possibilitar aos estudantes a construção do conhecimento de forma sistematizada e intencional. Sobre isso, ainda no final do século XX, os Parâmetros Curriculares Nacionais - PCN afirmavam que:

É importante que a Matemática desempenhe, no currículo, equilibrada e indissociavelmente, seu papel na formação de capacidades intelectuais, na estruturação do pensamento, na agilização do raciocínio do aluno, na sua aplicação a problemas, situações da vida cotidiana e atividades do mundo do trabalho e no apoio à construção de conhecimentos em outras áreas curriculares (BRASIL, 1998 p. 28)

Os Parâmetros Curriculares Nacionais - PCN ressaltavam a importância da matemática na formação do indivíduo para sua atuação na sociedade. Conteúdos matemáticos podem ser aplicados em várias situações do seu cotidiano, estimulando também o raciocínio para a resolução de problemas que venham a surgir no decorrer da trajetória do estudante. Nesse sentido, é importante inserir no currículo da escola metodologias que estimulem o gosto pela matemática, desmistificando a compreensão equivocada da matemática como uma área de conhecimentos complexos e inacessíveis.

No entanto, essas dificuldades de aprendizagem na matemática, poderão ser superadas se a escola e os/as professores/as adotarem metodologias de ensino mais próximas das necessidades dos estudantes, saindo do tradicionalismo que ainda é recorrente nas salas de aula. Para isso é necessário inovar, utilizar instrumentos que facilitem a compreensão e torne mais prazeroso o estudo dessa ciência. É sobre essa metodologia de ensino que Alves (2001, p. 25) afirma que: "o jogo pode fixar conceitos, motivar os alunos, propiciar a solidariedade entre os colegas, desenvolver o censo crítico e criativo, estimular o raciocínio, descobrir novos conceitos".

Diante dessa afirmação, podemos constatar que ao ter contato com atividades lúdicas, como jogos e brincadeiras durante as aulas no ensino da matemática, os alunos/as têm a oportunidade de movimentarse, estimulando a motricidade do corpo e da mente, aproveitando melhor o ambiente que lhe é proporcionado. A aula com elementos lúdicos desenvolve-se como um momento de descontração associado a situações de aprendizagem de conteúdos sistematizados, demonstrando que é possível aprender no ambiente escolar de uma forma divertida e prazerosa.

Assim, ao poporcionar atividades lúdicas para as crianças nos anos iniciais, é possívél que a aprendizagem se torne mais significativa, pois é valorizada a capacidade que a criança tem de entender algo novo a partir da relação com outros sujeitos e com o ambiente de maneira colaborativa. A aprendizagem ocorre do plano social para o indivídual. Sendo assim, aqueles sujeitos que possuem maior experiência contribuem para a aproprição das significações culturais daqueles sujeitos com menor experiência (Jacometo; Tabile, 2017).

O contato das crianças com colegas e professores favorece, no ambiente da escola, que os sujeitos se apropriem de conhecimentos e modos de compreender o mundo que necessariamente não fazem parte do repertório de conhecimentos construídos no convívio social fora da escola. 
Embora a matemática esteja presente em diversos contextos da vida em sociedade, é na escola que os sujeitos aprendem a sistematizar os conhecimentos da área. Neste sentido, a forma como os professores abordam os conteúdos formais será essencial para que os alunos desenvolvam o interesse para se apropriar de conteúdos específicos desse campo do conhecimento.

\section{RESULTADOS E DISCUSSÃO}

Ao realizarmos reuniões para elaboração do projeto relacionado a matemática, buscamos enfatizar elementos significativos do cotidiano dos alunos/as para a aplicação das atividades através de jogos e brincadeiras, visando dar compreensão às regras, aos procedimentos e às estratégias dos jogos, às relações com situações-problema do cotidiano dos alunos/as, seus objetivos ao que se refere aos conhecimentos matemáticos.

A construção das atividades pedagógicas para o processo de ensino e aprendizagem através de jogos matemáticos no ensino fundamental buscou a motivação no gosto pela matemática, visando desenvolver situações que estimulem nas crianças o raciocínio lógico, a tomada de decisão, de modo a explorar várias possibilidades, analisando ações que possibilitem o desenvolvimento dos sujeitos.

Até o presente momento, a nossa prática dentro do projeto didático, consolidou-se no formato de oficinas com jogos em uma sala temática. Nas oficinas, estão sendo desenvolvidos jogos com multiplicação, adição, subtração e divisão. Ao fim de cada atividade, percebemos que as crianças aprendem um pouco mais sobre como trabalhar sistematicamente com números no processo de resolução das operações matemáticas. Desta forma, trabalhando com jogos matemáticos, os alunos perceberam que todos são vencedores, pois com a nossa ajuda, apesar das dificuldades, todos conseguem resolver os problemas colaborativamente.

Estamos constatando até aqui, que dificuldades são encontradas pelos alunos ao tentar resolver as operações. Mas, com a aplicação dos jogos e brincadeiras, os estudantes demonstraram interesse em participar e repetir as atividades solicitadas. Isso, de certo modo, demonstra que atividades lúdicas são eficazes para a abordagem dos conteúdos matemáticos; além de despertar o interesse dos estudantes que se tornam mais ativos no processo de construção do conhecimento, aprendendo os temas abordados de forma divertida e prazerosa. Durante a execução dos jogos, muitas das crianças conseguem compreender mais rapidamente as operações envolvidas. Os alunos que têm mais facilidade em revolver problemas, ajudam os que apresentam maiores dificuldades. Aqueles que têm dificuldades mais acentuadas, recebem a nossa orientação de forma mais individualizada para que alcancem os resultados esperados.

Durante as aplicações, pode-se notar também que os alunos quando erram, não se sentem desmotivados com o erro; na verdade, têm vontade de acertar e são constantemente motivados a aprender. Assim, conclui-se que o projeto está possibilitando às crianças uma percepção mais clara dos conteúdos matemáticos, uma vez que grande parte das dúvidas estão sendo sanadas durante a aplicação das atividades pedagógicas em cada ação do projeto.

\section{CONSIDERAÇÕES FINAIS}

A partir das atividades que já foram desenvolvidas no projeto "A importância de atividades lúdicas para a aprendizagem da matemática por crianças do ensino fundamental: uma experiência a partir do Pibid”, é possível perceber que dificuldades na aprendizagem da matemática ainda são recorrentes nas salas de aula, sobretudo no que se refere a operações que exigem raciocínio mais complexo como a multiplicação e a divisão. Em relação às quatro operações básicas da matemática, estas duas são as que se apresentam como mais complexas para a compreensão dos discentes. Contudo, quando estes conteúdos são abordados por meio de atividades lúdicas, os estudantes mostram-se bastante atentos e participativos durante a realização de jogos e brincadeiras. Isso nos permite inferir que o problema não está necessariamente nos conteúdos matemáticos em si, mas, talvez, na maneira como são pedagogicamente abordados no contexto da sala de aula.

É necessário destacar que os jogos e brincadeiras, quando utilizados dentro de uma proposta pedagógica, precisam ser orientados para que os objetivos de aprendizagem não se percam. As atividades lúdicas, pensadas dentro de um projeto didático, têm fins específicos que estão associados ao processo de construção do conhecimento. Não se trata, portanto, de desenvolver ações para o mero entretenimento, mas para a (re)significação da aprendizagem de forma dinâmica e prazerosa. 
Como ressaltado anteriormente, neste texto foram apresentados alguns resultados prévios de um projeto didático que ainda está em andamento. De modo geral, o contato com as crianças em cada ação pedagógica desenvolvida nos convida a refletir sobre a relação destes sujeitos com a matemática, sobretudo com o processo de construção de conhecimentos na área. Percebemos que os estudantes demonstram compreender de forma significativa os conteúdos abordados nos jogos e brincadeiras, embora, contraditoriamente, apresentem dificuldades acentuadas no processo de sistematização destes mesmos conteúdos por meio de exercícios e atividades escritas. Por que isso acontece? 0 que os docentes poderiam fazer para solucionar este problema? Estes são questionamentos para os quais não temos respostas, mas que constituem um campo aberto para futuras pesquisas.

\section{REFERÊNCIAS}

[1] Alves, E. M. S. A Ludicidade e o ensino de matemática: Uma prática possível. Campinas, SP: Papirus, 2001.

[2] Brasil, 1998. Parâmetros Curriculares Nacionais: Terceiro e quarto ciclos do Ensino Fundamental. Disponível em: http://portal.mec.gov.br/seb/arquivos/pdf/matematica.pdf Acesso em: 02 de out.de 2019.

[3] Klausen, L. S. Aprendizagem significativa: um desafio. Anais do XIII Congresso Nacional de Educação Educere. Curitiba: PUC-PR, 2017. Disponível em: https://educere.bruc.com.br/arquivo/pdf2017/25702_12706.pdf. Acesso em: 30 de set. 2019.

[4] Silva, L. V; Angelim, C. P. O lúdico como ferramenta no ensino da matemática. Id Online: Revista Multidisciplinar e de Psicologia. v. 11, n. 38, p. 897-909, 2017. Disponível em: https://idonline.emnuvens.com.br/id/article/view/959/1352. Acesso em: 30 de set. 2019.

[5] Tabile, A. F.; Jacometo, M. C. D. Fatores influenciadores no processo de aprendizagem: um estudo de caso. Rev. psicopedag., São Paulo, v. 34, n. 103, p. 75-86, 2017 . Disponível em:

http://pepsic.bvsalud.org/scielo.php?script=sci_arttext\&pid=S0103-84862017000100008\&lng=pt\&nrm=iso. Acesso em: 30 de set. 2019.

[6] Trobia, I. A. et al. Avançando com o resto no ensino da matemática. Anais do 13o Conex. Ponta Grossa: UEPG, 2018. Disponível em: https://sites.uepg.br/conex/anais/anais_2015/anais2015/644-1858-1-RV-mod.pdf Acesso: 02 out. 2019. 


\section{Capítulo 25}

As mulheres na matemática e suas principais contribuições

Alane Élen Silva de Medeiros
Gisele Regina Santos Oliveira

Resumo: 0 enfoque principal deste trabalho é apresentar a trajetória das mulheres pioneiras que atuaram na área da matemática, com os preconceitos enfrentados nos séculos anteriores devido a matemática ser conhecida como a ciência dos homens e a educação feminina voltada para o lar, apresentar que entre tantas adversidades as mulheres contribuíram para a matemática e até mesmo nos dias de hoje desconhecemos essas guerreiras e suas grandes contribuições.

Palavras- chave: Contribuições, matemática e mulheres. 


\section{INTRODUÇÃO}

A matemática é uma das ciências mais antigas da humanidade, os primeiros relatos datam a aproximadamente 3200 a.C dos egípcios. Na história da matemática podemos observar o surgimento da álgebra, aritmética, entre outras áreas, temos conhecimentos de vários teoremas e suas contribuições associadas aos homens. Porém, na grande maioria não conhecemos a participação das mulheres na trajetória da história da matemática.

Na história da matemática a presença feminina, porquanto, em termos de registro, sempre foi esporádica. Na mais antiga escola dessa especialidade, pitagórica, uma lembrada é Theano, nascida em 546 a.C., E também conhecida como filósofa e física. Essa foi aluna de Pitágoras e supõe-se que tenha sido sua mulher. Acredita- se que ela e as duas filhas tenham assumido a escola pitagórica após a morte do marido (Nascimento, 2013).

No decorrer de séculos, as mulheres foram discriminadas, desencorajadas e proibidas de estudar, mas houve mulheres matemáticas que confrontaram e lutaram contra os preconceitos e empecilhos, marcando seus nomes na história matemática.

A discriminação institucionalizada contra as mulheres continuou até o século $\mathrm{XX}$, quando Emmy Noether, descrita por Einstien como "o mais significante gênio matemático criativo já produzido desde que as mulheres começaram a cursar os estudos superiores", teve negado seu pedido para dar aulas na Universidade de Göttingen. (Singh, 2005).

A discriminação institucionalizada foi um dos maiores empecilhos enfrentados pelas matemáticas, elas recebiam muitas críticas como do sueco August Strindberg, contestando à nomeação de Sofia Kovalevskaia como professora de matemática na Universidade de Estocolmo, em 1889, se expressou da seguinte maneira : "Tão decididamente como dois e dois fazem quatro, é uma monstruosidade uma mulher que é uma professora de matemática, e como ela é desnecessária, ultrajante e está fora de lugar".

Questionamentos são feitos frequentemente sobre a participação feminina na matemática se referindo as contribuições, que foram pequenas e inferiores às masculinas. Toda via não se pode esquecer que a ciência, desde seus primórdios, suprimiu as mulheres. Nos séculos XVII e XVIII, as poucas mulheres que conseguiram se adentrar na "[...] fortaleza do saber pelas portas dos fundos. [...] ficaram renegadas à condição marginal de assistentes ou, no melhor dos casos, de colaboradoras de cientistas conhecidos, ficando frequentemente ignoradas para a posteridade" (Tosi, 1998, p.380).

A sociedade por muito tempo afirmou que as mulheres não gostam de matemática, mas Ferrand (1994, p. 359) questiona: "Será que são as moças que não gostam de matemática ou a matemática que não gosta das moças?" A autora esclarece que essas ideias caracterizam as construções históricas e culturais nas quais foram moldadas, como aborda(Menezes, 2015p.25)

"[...] a matemática foi moldada através das concepções de que as "moças" não apresentam capacidades cognitivas próprias ao seu domínio; em contrapartida, as moças foram criadas de forma a não desenvolver o gosto pelas aptidões matemáticas, pois, estas são consideradas inerentes apenas aos homens. Essa problemática se fundamenta na construção de certos discursos e pensamentos ditos "ingênuos" que acabam se cristalizando como "verdades naturais".

As moças eram ensinadas a não conhecer a matemática, e se despertam interesse por essa área de conhecimento eram desprezadas. Porque mulher não tinha capacidade de estudar matemática.

\section{JUSTIFICATIVA}

Através de séculos, a participação das mulheres na área da matemática foi de difícil acesso ou até mesmo proibida, devido essa ciência tão antiga ser essencialmente dominada pelo universo masculino. A história das mulheres na matemática não é vista no Ensino básico, até mesmo nos quatro anos da graduação em matemática não estudamos sobre elas, conhecemos apenas um seleto grupo de grandes matemáticos que contribuíram para o avanço dessa ciência, não detemos do conhecimento da atuação de mulheres e se existiu essa participação. 
Por isso, é de grande relevância saber que possuímos a cooperação de mulheres no desenvolvimento da matemática. "[...] quando se fala em mulher e ciência, a reação imediata é de indicar a ausência de mulheres no desenvolvimento desta atividade ao longo da história”. (Sedeño e Garcia,1992, p.3).

As mulheres que se dedicavam a matemática enfrentavam muitos preconceitos. Essas guerreiras tiveram que ultrapassar os costumes e as barreiras sociais para poderem estudar e contribuir. Gauss, referiu-se em carta a Sophie Germain da seguinte maneira.

\begin{abstract}
"Mas quando uma pessoa pertencente ao sexo do qual, de acordo com nossos costumes e preconceitos, é forçada a enfrentar infinitamente mais dificuldades do que os homens para familiarizar-se com essas pesquisas dificílimas, e consegue com êxito, penetrar nas partes mais obscuras delas, não obstante, se para isso tenha de superar todas as barreiras existentes, então essa pessoa tem necessariamente, a mais nobre coragem, os mais extraordinários talentos e uma genialidade superior."
\end{abstract}

\title{
3. OBJETIVOS
}

\subsection{OBJETIVO GERAL}

Apresentar a trajetória das mulheres na matemática e suas principais contribuições.

\subsection{OBJETIVOS ESPECÍFICOS}

I. Evidenciar as dificuldades relacionadas à presença feminina no campo da matemática.

II. Identificar as principais mulheres que contribuíram para o desenvolvimento da matemática.

III. Mencionar o processo histórico das principais mulheres brasileiras que se dedicaram a matemática.

\section{METODOLOGIA}

O desenvolver do trabalho dar-se-á através da pesquisa bibliográfica, que se caracteriza com uma pesquisa realizada através do estudo de fontes secundárias que tratam, de diferentes maneiras, o tema abordado para estudo. As fontes são geralmente livros, artigos, documentos monográficos, periódicos (jornais, revistas, entre outros), textos disponíveis em sites confiáveis, entre outros locais que apresentam um conteúdo documentado.

A pesquisa bibliográfica é feita a partir do levantamento de referências teóricas já analisadas, e publicadas por meios escritos e eletrônicos, como livros, artigos científicos, páginas de web sites. Qualquer trabalho científico inicia-se com uma pesquisa bibliográfica, que permite ao pesquisador conhecer o que já se estudou sobre o assunto. (Fonseca, 2002, p. 32).

A pesquisa bibliográfica tem o intuito de se aprofundar em um determinado tema, como estudar teorias, investigar o assunto, consultar algumas fontes de estudo para se aprofundar no delineamento da pesquisa, explicando o objeto investigado.

A pesquisa bibliográfica é então feita com o intuito de levantar um conhecimento disponível sobre teorias, a fim de analisar, produzir ou explicar um objeto sendo investigado. A pesquisa bibliográfica visa então analisar as principais teorias de um tema, e pode ser realizada com diferentes finalidades. (Chiara, Kaimen, et al., 2008). 


\section{REFERÊNCIAS}

[1] Cavalari, Mariana Feiteiro. história, mulheres e educação matemática. 2010.

[2] Disponível em: <mfcavalari@unifei.edu.br>. Acesso em: 09 jun. 2018.

[3] Chiara, I. D. et al. Normas de documentação aplicadas à área de Saúde. Rio de Janeiro: Editora E-papers, 2008.Acesso em 08 jun.2018.

[4] Fonseca, J. J. S. Metodologia da pesquisa científica. Fortaleza: UEC, 2002. Acesso em 08 jun.2018.

[5] Ferrand, Michèle. A exclusão das mulheres da prática das ciências: uma manifestação sutil da dominação masculina. Florianópolis: Revista Estudos Feministas,2, 1994.Acesso em:30 maio 2018.

[6] Menezes, Márcia Barbosa de. a matemática das mulheres: as marcas de gênero na trajetória profissional das professoras fundadoras do Instituto de Matemática e Física da Universidade da Bahia. (1941-1980). 2015. 381 f. Tese (Doutorado) - Curso de Matemática, A. Faculdade de Filosofia e Ciências Humanas, Universidade Federal da Bahia.,

[7] Salvador, 2015. Disponível em: <https://repositorio.ufba.br/ri/bitstream/ri/23639/1/Tese.pdf>. Acesso em: 30 maio 2018.

Nascimento, João Batista do. Algumas Mulheres da História da Matemática: e a questão de gênero em ciência e tecnologia. 2013. Disponível em:

<https://www.mathunion.org/fileadmin/CDC/cdc.../mulheres.matematica.maio.13.pdf>. Acesso em: 10 jul. 2018. 


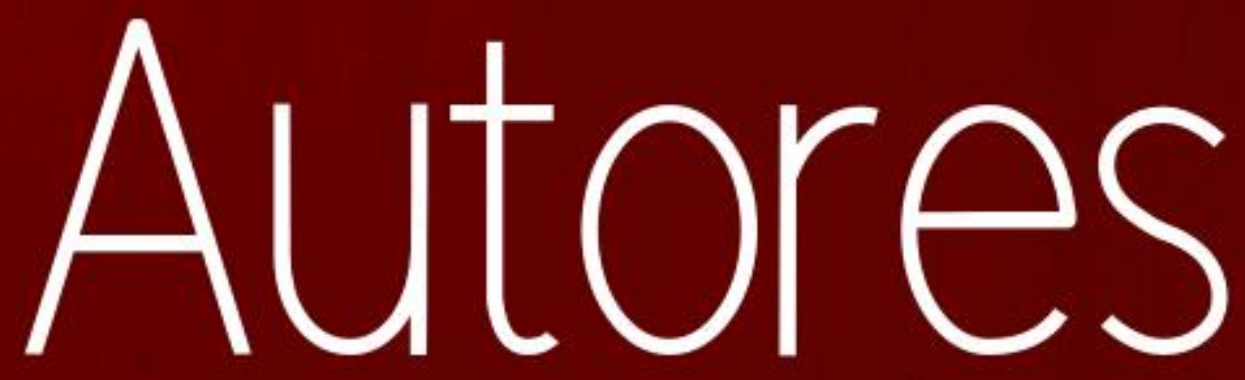




\section{ALANE ÉLEN SILVA DE MEDEIROS}

Acadêmica em matemática- UERN

\section{ARMANDO DA SILVA PEREIRA NETO}

Graduando em Licenciatura em Matemática pela Universidade de Pernambuco - Campus Garanhuns. Integrante do grupo de pesquisa Física Aplicada e Matemática Computacional (FAMAC), vinculado ao CNPq.

\section{AZENATE PEREIRA DE SOUSA}

Pedagoga graduada. Pós-graduada em Gestão e Supervisão com Habilitação em Docência do Ensino Superior e colaboradora da Faculdade ISEPRO. Especialista em educação. Experiência em design gráfico, coordenação de atividades pedagógicas e auxiliar administrativa acadêmica.

\section{BIANCA DAÉB'S SEIXAS ALMEIDA}

Docente da Faculdade Dom Pedro Segundo, Docente Substituta no curso de Pedagogia da FACED/UFBA, Doutora em Educação e Mestra em História Social, graduada em Pedagogia, Filosofia e Direito, atuando principalmente nas áreas de Formação Pedagógica, Direito Educacional, Gênero e Educação, e Direitos Humanos.

\section{BRUNO THAYGUARA DE OLIVEIRA RIBEIRO}

Licenciado em Matemática pela Universidade Federal do Amazonas-UFAM-2010 Especialista em Metodologia do Ensino da Matemática pela Universidade Estadual do AmazonasUEA-2012. Especialista em Metodologia do Ensino na Educação de Jovens e Adultos pela FAEL2018. Mestrando em Ciências da Educação pela Universidade Autônoma de Assunção

\section{CESAR MARCOS DO NASCIMENTO LUCAS}

É licenciado em Matemática pela Universidade Estadual Vale do Acaraú (UVA) - 2011; Especialista em Ensino de Matemática pela mesma instituição - 2014 e Mestre em Matemática/PROFMAT na Universidade Federal do Piauí - UFPI - 2017. Atuou como professor na Rede Municipal de Ensino da Cidade de Sobral de 2011 a 2014 e na Rede Estadual de Ensino do Estado do Ceará de 2014 a 2017, atualmente é Professor do Ensino Básico Técnico e Tecnológico (EBTT) do Instituto Federal do Piauí.

\section{CLEBSON SANTOS DA SILVA}

Graduando em Licenciatura em Matemática-UFPB

\section{DÂMOCLES AURÉLIO NASCIMENTO DA SILVA ALVES}

Possui graduação em Licenciatura em Matemática pela Universidade Federal Rural de Pernambuco (2004); Mestrado em Estatística Aplicada e Biometria pela Universidade Federal Rural de Pernambuco (2006); Doutorado em Biometria e Estatística Aplicada da Universidade Federal Rural de Pernambuco (2014). Compõe o Grupo de Pesquisa na UPE / Campus Garanhuns FAMAC (Física Aplicada, Matemática Aplicada e Computacional). Compõe a Coordenação do LAMAC (Laboratório de Matemática Aplicada e Computacional), vinculado ao FAMAC. Tem experiência na área de Processos computacionais, Educação a distância, Probabilidade e Matemática, com ênfase em Matemática e Estatística.

\section{DARLAN DOUGLAS BARROS PEREIRA}

Graduando de licenciatura plena em matemática na Universidade do Estado do Pará-UEPA. 


\section{DUELCI APARECIDO DE FREITAS VAZ}

Licenciado em Matemática pela Puc Goiás. Mestre em Matemática pela Universidade Federal de Goiás. Doutor em Educação Matemática pela Unesp de Rio Claro-SP. Atua na área de Tecnologias na Educação Matemática e na Histórico Cultural.

\section{EDIMAR CAMPELO ARAUJO}

Educador Físico, Historiador pedagogo. Especialista e Mestre em Educação, Doutorando em Educação. Professor aposentado da rede estadual do Piauí. Experiência docente de mais de 20 anos no Ensino Superior. Desempenho em satisfação orientação de pesquisa acadêmica. Palestrante de temas educacionais. Educador por paixão.

\section{EDIVAN VIEIRA LIMA}

Graduado em Licenciatura Plena em Matemática pela Universidade de Uberaba - UNIUBE, pósgraduado em Ensino de Matemática pela Faculdade Futura, mantida pelo Instituto de Ciências, Educação e Tecnologia de Votuporanga. Professor de Matemática em regência de 1997 à 2003 na rede estadual de ensino do estado do Mato Grosso, retornando as atividades no ano de 2018.

\section{EDUARDO DA SILVA ANDRADE}

Graduando em Licenciatura em Matemática-UFPB.

\section{EGRACIELI DOS SANTOS ANANIAS}

Graduada em Licenciatura em Matemática-UFPB

\section{ELIVANETE ALVES DE JESUS}

Licenciada em Matemática pela Universidade Federal de Goiás. Mestre e Doutorada em Educação Matemática pela Unesp de Rio Claro-SP. Pesquisadora na área de Etnomatemática e formação de professores.

\section{ELOY DA SILVA ROCHA}

Licenciado em Matemática pela Universidade Federal do Amazonas-UFAM Mestre em Matemática pela Rede PROFMAT-UFAM-2018

\section{EMANUELLA SILVEIRA VASCONCELOS}

Doutoranda em Educação em Ciências e Matemática pela Pontifícia Universidade Católica do Rio Grande do Sul - PUCRS, Mestre em Ensino de Ciências pela Universidade Estadual de Roraima UERR (2017), Especialista em Educação Infantil pela Universidade Federal de Roraima - UFRR (2012) e Graduada em Pedagogia pela Universidade Federal de Roraima - UFRR (2009). Atualmente é professora efetiva da UFRR, atuando na Educação Básica do Colégio de Aplicação CAp/UFRR. Atuou em classes de Educação Infantil (2005 à 2013) na rede pública e na rede privada de educação, no Ensino Fundamental ( 2009-2013), na graduação ( 2011-2012) e na pósgraduação (2014). É membro ativo dos Grupos de Pesquisa: Grupo de Estudo e Pesquisa Interdisciplinar em Educação (GEPINTE/CNPQ); Dídática, possibilidades metodológicas e práticas em Educação (UFRR/CNPQ); Didática da Resolução de Problemas em Ciências e Matemática (UFRR/CNPQ). Pesquisa atualmente temas referente a processos de ensino-aprendizagem, Alfabetização Científica, Tecnologias na Educação e Formação de professores. 


\section{EMÍLIA DE MENDONÇA ROSA MARQUES (MARQUES, E.M.R.)}

Licenciada em Matemática pela UNESP/RC (1986), mestre em Álgebra (1990) e doutora Engenharia Elétrica (1999) pela UNICAMP. Docente da UNESP/Bauru desde 1990. Possui experiência na área de Telecomunicações, aplicando a Teoria dos Números à Teoria de Códigos. Pesquisa em Ensino de Matemática com uso de TIC, área na qual realizou em 2009/2010 um estágio de Pós-Doutorado na Universidade de Aveiro - UA/Portugal. Tem atuado na confecção de material e treinamento de tutores para Educação Continuada de Professores do Ensino Básico, nos diversos níveis e na formação inicial de professores de Matemática. Atualmente é Coordenadora de Área do PIBID/Matemática/Unesp e membro do grupo de pesquisa "Ensino de Ciências e Tecnologia Educacional" (cadastro CNPq) e do Instituto de Educação e Pesquisa em Práticas Pedagógicas "Adriana Chaves" - IEP3/UNESP.

\section{ERIVELTON DA SILVA PAZ}

Acadêmico do $6^{0}$ período do curso de Licenciatura Plena em Matemática da Universidade de Pernambuco - Campus Garanhuns.

\section{FRANCKLIM SIDENEY VIDAL DE SANTANA}

Graduando em Licenciatura em matemática pela Universidade do Estado do Pará - UEPA

\section{GISELE REGINA SANTOS OLIVEIRA}

Acadêmica de matemática-UERN

\section{GISELE SCREMIN}

Mestre em Ensino de Ciências Exatas, na Univates de Lajeado/RS (2019). Possui especialização em Tecnologias da Informação e Comunicação aplicadas à Educação pela UFSM (2017), graduação em MATEMÁTICA pela Universidade Regional Integrada do Alto Uruguai e das Missões (2009) e habilitação para Magistério (Educação Infantil e Séries Inicias, 2005).Tem experiência na área de educação de jovens e adultos, ensino de matemática e tecnologias.Áreas de interesse: Tecnologias em matemática, Educação Matemática e Matemática Aplicada.

\section{GRAZIELA AQUINO DO NASCIMENTO}

Graduanda em Pedagogia pela Universidade do Estado da Bahia - UNEB, Campus VII, Senhor do Bonfim

\section{HAILSON DA COSTA TRINDADE}

Graduando em Licenciatura em matemática pela Universidade do Estado do Pará - UEPA

\section{HELLEN CRIS DE ALMEIDA RODRIGUES}

Possui graduação em Licenciatura em Pedagogia pela Universidade Federal de Roraima - UFRR (2014). Graduada em Licenciatura em Educação Física pelo Centro Universitário Claretiano (2017). Especialista em Gestão Escolar pela Universidade Federal de Roraima - UFRR (2015). Mestre em Educação pela Universidade Estadual de Roraima - UERR (2018). Doutoranda em Educação pela Universidade Federal do Amazonas (UFAM). Foi pedagoga no Instituto Federal de Roraima/IFRR/Campus Novo Paraíso atuando como coordenadora na Coordenação de Assistência ao Estudante - CAES (2014-2016). Atualmente é professora efetiva no Colégio de Aplicação CAp/UFRR. Seus trabalhos são direcionados a área da Educação, atuando principalmente nos temas: Educação Infantil, Práticas de leitura, formação de professores e Educação no Campo. 


\section{ISMAEL SMYLLE DA SILVA QUIRINO}

Graduando de licenciatura plena em matemática na Universidade do Estado do Pará-UEPA.

\section{ITALO GABRIEL NEIDE}

Possui Bacharelado (2004) e Mestrado (2007) em Física e Doutorado em Ciências (ênfase Física Teórica) (2011) pela Universidade Federal do Rio Grande do Sul. Pós Doutor pela Universität Duisburg-Essen. Desenvolveu colaborações na PUC-Chile e University of New Mexico. Atualmente é professor do Centro Universitário UNIVATES, atuando nos cursos de graduação e no Mestrado em Ensino de Ciências Exatas. Tem experiência na área de Física da Matéria Condensada, Modelos Teóricos Computacionais e Ensino de Física, atuando principalmente nos seguintes temas: Modelagem Matemática, Uso de Tecnologias no Ensino da Matemática, Atrito Atômico, Tribologia e Simulações de Sistemas Físicos.

\section{IVAN RODRIGUES DE MOURA}

Graduando em Licenciatura Plena em Matemática pelo Instituto Federal de Educação, Ciência e Tecnologia do Piauí Campus Angical

\section{JEAN OLIVEIRA DA SILVA}

Graduando em Licenciatura em matemática pela Universidade do Estado do Pará - UEPA

\section{JÉSSICA CLÁUDIA LIMA DOS SANTOS}

Graduada em Licenciatura em Matemática-UFPB

\section{JOÃO LUÍS DA COSTA BARROS}

Graduado em Educação Física pela Universidade Federal do Amazonas - UFAM (1987). Mestre em Educação Física pela Universidade Metodista de Piracicaba - UNIMEP/SP (2005). Doutor em Educação pela Universidade Metodista de Piracicaba - UNIMEP/SP (2012). Pós-doutor em Educação pela Universidade Estadual do Ceará - UECE (2019). É professor adjunto da Universidade Federal do Amazonas (UFAM), atuando na Faculdade de Educação Física e Fisioterapia FEFF/UFAM. Professor permanente nos cursos de pós-graduação stricto sensu em Educação PPGE/UFAM e do Programa de Pós-Graduação Sociedade e Cultura na Amazônia - PPGSCA/UFAM, onde ministra disciplinas obrigatórias e eletivas com orientações de dissertações e teses. Líder do Grupo de Pesquisa - GEPEFRI/CNPq: Educação Física e suas relações interdisciplinares. Participa dos colegiados de licenciatura e bacharelado em Educação Física - FEFF. Tem experiência na área de Educação Física e Educação, atuando principalmente nos seguintes temas: lúdico, escola, jogo e criança, Formação e identidade docente; Formação e Desenvolvimento Profissional em Educação e Educação Física. É membro do Comitê de Ética em Pesquisa - CEP/UFAM. É avaliador institucional do Ministério da Educação - MEC/INEP/e-mec/ BASIs.

\section{JOSÉ JORGE CASIMIRO DOS SANTOS}

Possui Graduação em Licenciatura em Matemática pela Universidade Federal de Campina Grande (2015), Especialização em Educação Matemática pela Belchior Consultoria \& Projetos em parceria com a Faculdade São Francisco da Paraíba (2015), Mestrado em Educação Matemática pelo do Programa de Pós-graduação de Ensino de Ciências e Educação Matemática da Universidade Estadual da Paraíba (2018). Atualmente é professor efetivo de Matemática do Estado do Rio Grande do Norte. Tem interesse em pesquisas relacionadas a Educação Matemática com ênfase processo de ensino e aprendizagem, formação de professores, memória e Educação de Jovens, adultos e idosos. 


\section{LEONARDO CINÉSIO GOMES}

Licenciado em Matemática-UFPB, Especializando em Metodologia em Ensino de MatemáticaCentro Universitário Leonardo da Vinci, Especializando em Educação de Jovens e Adultos - IFRO. Professor do Ensino Médio da rede estadual de ensino, do estado da Paraíba. Membro do grupo de Pesquisa, coletivo de Pesquisa pelos valores dos saberes potiguara.

\section{LINDIANE DUARTE DA SILVA}

Graduanda em Pedagogia pela Universidade do Estado da Bahia - UNEB, Campus VII, Senhor do Bonfim - Bahia. Técnica em Agronegócio pelo Serviço Nacional de Aprendizagem Rural - SENAR, Polo Senhor do Bonfim - Bahia. Técnica em Zootecnia pelo Instituto Federal Baiano, Campus Senhor do Bonfim - Bahia

\section{LUCIANO CERQUEIRA}

Licenciatura em Matemática pela UFSC - Universidade Federal de Santa Catarina; Pós Graduado em Ciências da Natureza, Matemática e sua tecnologias; Mestrando do Programa de Pós-Graduação Mestrado Profissional em Tecnologias Aplicáveis à Bioenergia da Faculdade de Tecnologia e Ciências FTC; Professor de Matemática efetivo Secretaria de Educação do Município de Salvador do Estado da Bahia; Professor de Matemática efetivo Secretaria de Educação do Estado da Bahia.

\section{MAISE SILVA}

Doutora em Ciências Biológicas (Zoologia). Docente titular da Faculdade de Tecnologia e Ciências (FTC). Docente-orientadora do Mestrado Profissional em Tecnologias Aplicáveis á Bioenergia. Organizadora do Livro "Educação para além do Século XXI". Editora da Revista Diálogos \& Ciência (D\&C). Editora da Revista de Inovação, Tecnologia e Ciência (RITEC)

\section{MARCOS ANTONIO HELENO DUARTE}

Mestrado Profissional em Educação (UPE) e em Psicologia da Educação (ISLA-Portugal), Especialista em Informática na Educação (UFPE) e graduado em Licenciatura Plena em Matemática (UNICAP). Professor de Matemática na Educação Básica, experiência no Ensino Superior na Pósgraduação em Ensino de Matemática. Professor formador da Secretaria de Educação de PE. Pesquisador na área de Formação de Professores, Informática na Educação e Avaliação de Larga Escala.

\section{MARIA DOS MILAGRES FERNANDES DINIZ CHAVES}

Doutora em Ciências da Educação UNIDA; Mestra em Educação UFPB; Especialização em Psicopedagogia. Professora da Universidade Federal Rural do Semi-Árido - UFERSA, do curso de Medicina - Campus Mossoró. Experiência na área de Educação, com ênfase em Educação Especial, atuando principalmente nos seguintes temas: aprendizagem e habilidades de comunicação.

\section{MARIA MADALENA DULLIUS}

Possui Licenciatura Curta em Ciências pela Fundação Alto Taquari de Ensino Superior (1991), Licenciatura Plena em Matemática pela Fundação Alto Taquari de Ensino Superior (1993), Mestrado em Matemática Aplicada pela Universidade Federal do Rio Grande do Sul (2001) e Doutorado em Ensino de Ciências e Matemática pela Universidade de Burgos-Espanha (2009). Atualmente é professora Titular da Universidade do Vale do Taquari - UNIVATES, atuando no Mestrado em Ensino de Ciências Exatas (PPGECE) e no Mestrado em Ensino (PPGEnsino). Foi coordenadora do PPGECE e do PPGEnsino e desde 2014 é Pró-Reitora de Pesquisa, Extensão e PósGraduação. Tem experiência na área de Matemática, com ênfase em Matemática Aplicada e Ensino de Matemática, atuando principalmente nos seguintes temas: Modelagem Matemática, Uso de Tecnologias no Ensino da Matemática e Formação de Professores. 


\section{MARILENE ROSA DOS SANTOS}

Mestrado e Doutorado em Ensino de Ciências e Matemática pela Universidade Federal Rural de Pernambuco. Atualmente é coordenadora setorial de graduação, pertencente à Coordenação de Desenvolvimento da Graduação (CDG) da Universidade de Pernambuco -UPE. Professora Adjunta do curso de licenciatura em matemática - campus Garanhuns. Professora colaboradora do Programa de Pós-Graduação em Educação Matemática e Tecnológica/UFPE (EDUMATEC). Líder do grupo Intelectus de Pesquisa e Estudos em Educação Matemática (GIPEM)/UPE e o Semear/UFRPE(UAG). Pertence também, ao grupo Pró-Grandeza como pesquisadora. Tem experiência na área de Educação Matemática e Formação de Professor.

\section{MARNILDE SILVA DE FARIAS}

Possui graduação em Educação Física (2013) e Pedagogia (2016), especialização em Psicomotricidade (2014), Mestrado Acadêmico em Educação pela Universidade Estadual de Roraima (2016). Atuou como professora horista no curso de Educação Física da Universidade Estadual de Roraima e atuou como professora formadora, supervisora de estágio e orientadora no curso de Educação Física, ofertado pelo PARFOR no Instituto Federal de Roraima até maio de 2017. Professora efetiva na Educação Infantil e Ensino Fundamental do município de Caracaraí-RR, atualmente cursando Doutorado em Educação pela Universidade Federal do Amazonas com previsão de término para 2021, membra do Grupo de Pesquisa em Educação Física e suas relações interdisciplinares. Tem experiência na área de Educação Física Escolar, Psicomotricidade, Currículo, Alfabetização e Letramento, Formação de professores e Educação Inclusiva.

\section{MAXWELL GONÇALVES ARAÚJO}

Possui graduação em Licenciatura Plena em Matemática pela Pontifícia Universidade Católica de Goiás (1992) e mestrado em Educação em Ciências e Matemática pela Universidade Federal de Goiás (2009). Atualmente é professor efetivo, com Dedicação Exclusiva, do Instituto Federal de Educação, Ciência e Tecnologia de Goiás - campus Goiânia. Tem experiência na área de Educação, com ênfase em Métodos e Técnicas de Ensino, atuando principalmente nos seguintes temas: educação, racionalismo, crítica, comunicação, inclusão, educação e método.

\section{MAYARA DIAS DE ARAÚJO}

Graduada em Licenciatura em Pedagogia - Educação do campo pela Universidade Federal da Paraíba (2019) e professora dos anos iniciais da rede privada do município de João Pessoa, Paraíba. Atualmente desenvolve pesquisa junto ao Programa Prolicen da UFPB, priorizando o ensino de matemática para os anos iniciais e Formação de professores.

\section{MILENE DE FÁTIMA SOARES}

Graduação em Pedagogia (2002) e especialização em Psicopedagogia (2005) pelo Centro Universitário de Patos de Minas, UNIPAM. Mestre em Educação Matemática (2009) pela Universidade de Brasília, UnB. Tem experiência na Área de Educação, com ênfase em: Educação Matemática; Educação Lúdica, Docência na Educação Infantil, Anos iniciais do Ensino Fundamental, Ensino Superior e Pós-graduação. Educação a Distância - elaboração de material didático, planejamento, coordenação e tutoria em cursos técnicos, de capacitação, de graduação e pósgraduação. Consultorias educacionais - capacitação e formação continuada de professores em Educação Matemática e também Planejamento, Execução e Coordenação de Cursos de Capacitação e Formação Profissional em empresas. Atua com projeto de parceria universidade-escola na rede pública do Distrito Federal com formação na área de Educação Matemática. Atualmente é Professora no curso de Pedagogia no Centro Universitário IESB, nas modalidades presencial e a distância. 
Graduada em Pedagogia pelo Curso de Pedagogia do Centro Universitário Instituto de Educação Superior de Brasília - IESB (2018), com especialização em Gestão, Coordenação, Orientação Educacional e Educação Especial e Inclusiva (2019) pela Faculdade do Distrito Federal, FACDF. Atualmente é Pesquisadora na área de formação matemática de pedagogos.

\section{NAYARA LIMA DUTRA CAVALCANTE}

Graduada em Pedagogia pelo Curso de Pedagogia do Centro Universitário Instituto de Educação Superior de Brasília - IESB (2018). Atualmente é Pesquisadora na área de formação matemática de pedagogos e professora temporária na Secretaria de Estado de Educação do Distrito Federal.

\section{NICÉIAS SILVA VILELA}

Graduanda do curso de Licenciatura em Matemática pela Universidade de Pernambuco. Membro do grupo de pesquisa FAMAC - Física Aplicada, Matemática Aplicada e Computacional. Foi professora do programa Novo Mais Educação (2017), em Calçado/PE. Exerceu o cargo de Coordenadora do Censo Escolar e de Coordenadora do Sistema Presença/MEC, em Calçado/PE.

\section{OSIEL CÉSAR DA TRINDADE JÚNIOR}

Biólogo, Especialista e Mestre em Educação, Doutorando em Educação. Servidor público do Instituto Federal do Maranhão. Experiencia no Ensino Básico e superior, Desempenho com sucesso orientações de projetos acadêmicos e trabalhos de conclusão de cursos.

\section{PASCOAL ERON SANTOS DE SOUZA}

Doutorando em Ecologia Humana pelo Programa de Pós-Graduação em Ecologia Humana e Gestão Socioambiental, da Universidade do Estado da Bahia/Campus III. Mestre em Educação e Diversidade pelo Programa de Pós-Graduação em Educação e Diversidade - PPED/MPED/UNEB (2017). Tem especialização em Educação, Cultura e Contextualidade pela UNEB (2010); especialização em Psicopedagogia pela Faculdade Internacional de Curitiba- FACINTER/IBPEX (2002) e em Ensino da Língua Inglesa pela Universidade de Pernambuco - UPE (2006). Licenciatura em Pedagogia pela UNEB (2001) e Licenciatura em Língua Inglesa e suas Literaturas pela UPE (2007). É professor do Departamento de Educação do Campus VII/UNEB. Desenvolve estudos na área de Educação, com ênfase em Educação Inclusiva, Didática, Educação de Surdos, Pesquisa e Prática Pedagógica, e Ensino da Língua Inglesa

\section{PAULO CÉSAR DE JESUS CRUVINEL}

Formado em Licenciatura em Matemática pelo IFG - Campus Goiânia em 2013. Pós graduando em docência universitária pela UNIP e Professor da rede particular de ensino a 8 anos.

\section{PAULO MALICKA MUSIAU}

Possui graduação em Matemática pela Faculdade de Filosofia Ciências e Letras de Mandaguari (1999), Mestrado Nacional Profissional no Ensino de Física pela Universidade Federal de Rondônia (2015), Especialização em Docência do Ensino Superior pela UCAM (2003) e Especialização em Educação Matemática pela Universidade Federal de Rondônia (2005. Atualmente é professor concursado pela rede Estadual na Escola Alejandro Yague Mayor, município de Ji-Paraná-RO, com a disciplina de matemática. Tem experiência na área de Física, nos seguintes temas: física moderna, experimentos e ensino-aprendizagem, ensino de física e experimentos, ensino- aprendizagem e redes sociais e ensino-aprendizagem e jogos. Tem experiência na área de Matemática na Escola Família Agrícola de Ji-Paraná-RO, no sistema de alternância e aulas de Física no cursinho prévestibular. Também atua no Ensino Superior (UNIJIPA) no Curso de Engenharia Civil , Ambiental e Arquitetura com as disciplinas de Matemática elementar, Cálculo I e II, Equações Diferenciais , Física I e II e Cálculo Numérico. 


\section{RAIMUNDO NONATO BARBOSA CAVALCANTE}

É licenciado em Matemática pela Universidade Estadual Vale do Acaraú (UVA) - 2009; Especialista no Ensino de Matemática pela mesma instituição - 2012 e Mestre em Matemática pelo PROFMAT na Faculdade de Ciências e Letras do Sertão Central da Universidade Estadual do Ceará (FECLESC/UECE) - 2018. Atuou como professor da Rede Estadual de Ensino do Estado do Ceará de 2010 a 2019, atualmente é Professor do Ensino Básico Técnico e Tecnológico (EBTT) do Instituto Federal do Maranhão.

\section{ROSIMEYRE VIEIRA DA SILVA}

Possui graduação em Licenciatura Plena em Pedagogia pela Universidade Federal do Piauí (1999).Mestrado em Educação (UFPI).Especialização em Docência do Ensino Superior(UESPI). Especialista em Supervisão Escolar (UESPI). Experiência na área de Educação no Ensino Fundamental como professora e coordenadora pedagógica. Atualmente cursa Doutorado em Educação na UFPI, atua na Educação Superior com as Disciplinas Pedagógicas no curso de Licenciatura em Matemática no Instituto Federal de Educação, Ciência e Tecnologia do Piauí-IFPI. Professora Formadora I do PARFOR.

\section{SEVERINA ANDRÉA DANTAS DE FARIAS}

Graduada em Licenciatura em Matemática pela Universidade Federal da Paraíba (2005), Mestre em Educação pela Universidade Federal da Paraíba (2009) e Doutora em Educação pela Universidade Federal da Paraíba (2014). Atualmente é professora adjunta do Departamento de Educação do Campo, do Centro de Educação da UFPB (DEC/CE/UFPB), onde desenvolve pesquisas na linha ensino-aprendizagem, priorizando as metodologias de ensino de matemática para Educação Básica e formação de professores dos cursos de Licenciatura em Pedagogia e Licenciatura em Matemática.

\section{SHEILA MARQUES MOREIRA MEDEIROS}

Graduanda em Licenciatura em Pedagogia - Educação do campo pela Universidade Federal da Paraíba (2019). Atualmente desenvolve pesquisa junto ao Programa Prolicen da UFPB, priorizando o ensino de matemática para os anos iniciais e Formação de professores.

\section{SHEILA PIRES DOS SANTOS}

Graduada em Ciências Biológicas pela Universidade Paranaense (UNIPAR - campus Paranavaí), pós graduada em Metodologia de Ensino de Ciências Biológicas pelo Centro Universitário Leonardo da Vinci, foi professora regente de biologia pela rede Estadual de ensino do Mato Grosso, de 2011 à 2017 no município de Marcelândia, atuando desde 2018 como Orientadora da Área de Ciências da Natureza e Matemática na mesma instituição, inserida a partir da mesma data no Projeto Escola Plena de Ensino Integral.

\section{SHEYLA SILVA THÉ FREITAS}

Doutoranda e Mestre em Ciências da Educação UNIDA; Graduada em Letras e Pedagogia. Habilitação em Matemática e Física. Especialização em Gestão Educacional e Metodologia do Ensino Fundamental e Médio. Atua como professora UECE/UAB como experiência em educação matemática, educação infantil ao ensino fundamental, jogos matemáticos, formação docente, educação indígena e Quilombola.

\section{SOLIMAR BARROS RAMIRES}

Licenciado em Matematica pela UNEMAT. Especialista em Ensino da Matemática pela FINOM. Professor da rede estadual desde 2000. 


\section{THAMY SARAIVA ALVES}

Doutora em Comunicação, Linguagem e Cultura - Universidade da Amazônia - UNAMA; Mestre em Educação pela Universidade do Estado do Pará - UEPA; Especialista em Análises Linguísticas e Estudos Literários pela Universidade Estadual do Pará - UEPA; Especialista em Língua Portuguesa e Literaturas pela Faculdade Integrada Brasil Amazônia - FIBRA; Graduação em Licenciatura em Letras com Habilitação em Língua Portuguesa, Inglesa e Literaturas pela Universidade do Estado do Maranhão - UEMA

\section{VAGNER SANTOS DA SILVA}

Licenciado em Ciência da Computação - UFPB, Licenciando em Matemática - UFPB, Especializando em Educação de Jovens e Adultos - IFRO.

\section{VALMIRO DE SANTIAGO LIMA}

Doutor e Mestre em Ciências da Educação UNIDA; Especialização em Docência do Ensino Superior Especialização em Ensino de Matemática; Graduação em Matemática UFC e UECE; Graduação em Física IFCE; Atua como professor UECE/UAB, na área de Matemática: formação de professores inicial e continuada, educação matemática, educação indígena, ensino-aprendizagem, jogos pedagógicos e palestrante BNCC.

\section{VALTER LOCCI (LOCCI, V.)}

Graduado bacharel em Engenharia Civil pela Universidade de Uberaba (1984), mestre em Matemática pela Universidade de São Paulo - USP (1992) e doutor em Matemática pela Universidade de São Paulo - USP (1999). É Professor Assistente Doutor em regime de RDIDP do Departamento de Matemática da Faculdade de Ciências da Universidade Estadual Paulista Júlio de Mesquita Filho - UNESP/Bauru, com o ingresso em 1889. Tem experiência na área de matemática, com ênfase em Topologia Algébrica, atuando principalmente nos seguintes temas: geometria, métodos numéricos, equações diferenciais e funções hiperbólicas. Desde 2006 atua no PIC da OBMEP - Olimpíada Brasileira de Matemática das Escolas Públicas. Atualmente é Chefe do Departamento de Matemática da FC/Unesp/Bauru.

\section{VANIA DE MOURA BARBOSA DUARTE}

Doutoranda do Programa de Pós-graduação em Ensino das Ciências (UFRPE), Mestre em Ensino das Ciências (UFRPE), Especialista em Ensino de Matemática (UFPE) e graduada em Licenciatura em Matemática (UFRPE). Professora do curso de Licenciatura em Matemática da Universidade de Pernambuco com experiência e pesquisadora na área de Didática da Matemática, Tecnologias voltadas ao Ensino da Matemática e Formação de Professores.

\section{VILANI FERREIRA FEITOSA AMARAL}

Graduada em Licenciatura Plena em Pedagogia pela UFPI - Universidade Federal do Piauí

\section{WALISSON DA SILVA ARAÚJO}

Graduando do Curso de Licenciatura em Matemática pelo Instituto Federal de Educação, Ciência e Tecnologia do Piauí - Campus Piripiri.

\section{ZÉLIA MARIA DE ARRUDA SANTIAGO}

Graduação Pedagogia (UEPB) e Letras (UFCG). Especialização "Comunicação Educacional" (UEPB). Mestrado Interdisciplinar em Ciências da Sociedade (UEPB). Doutorado em Educação (UFPB). Docente do Departamento de Educação (UEPB), Especialização em Desenvolvimento Humano e Educação Escolar (UEPB), Programa de Pós-Graduação em Educação Matemática e Ensino de 
Ciências (PPGECEM/UEPB), Universidade Aberta à Maturidade (UAMA/UEPB). Coordena Projetos de Pesquisa e Extensão em Educação. Atua nas áreas de Linguística Aplicada e Educação, enfatizando os temas: formação continuada, alfabetização, multiletramentos, leitura e escrita, oralidade na sala de aula e intergeracionalidade. 


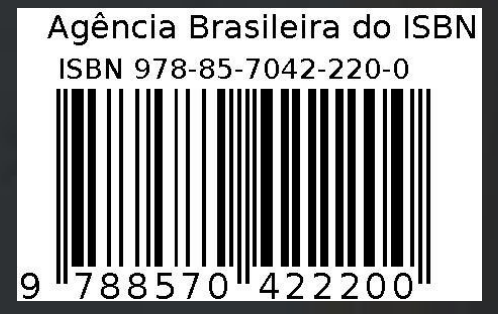

